\title{
Archaeological Investigations at 41BX1, Bexar County, Texas
}

\author{
Paul D. Lukowski
}

Follow this and additional works at: https://scholarworks.sfasu.edu/ita

Part of the American Material Culture Commons, Archaeological Anthropology Commons, Environmental Studies Commons, Other American Studies Commons, Other Arts and Humanities Commons, Other History of Art, Architecture, and Archaeology Commons, and the United States History Commons

Tell us how this article helped you.

This Article is brought to you for free and open access by the Center for Regional Heritage Research at SFA ScholarWorks. It has been accepted for inclusion in Index of Texas Archaeology: Open Access Gray Literature from the Lone Star State by an authorized editor of SFA ScholarWorks. For more information, please contact cdsscholarworks@sfasu.edu. 


\section{Archaeological Investigations at 41BX1, Bexar County, Texas}

Creative Commons License

(c) (i) (8)

This work is licensed under a Creative Commons Attribution-NonCommercial 4.0 International License 


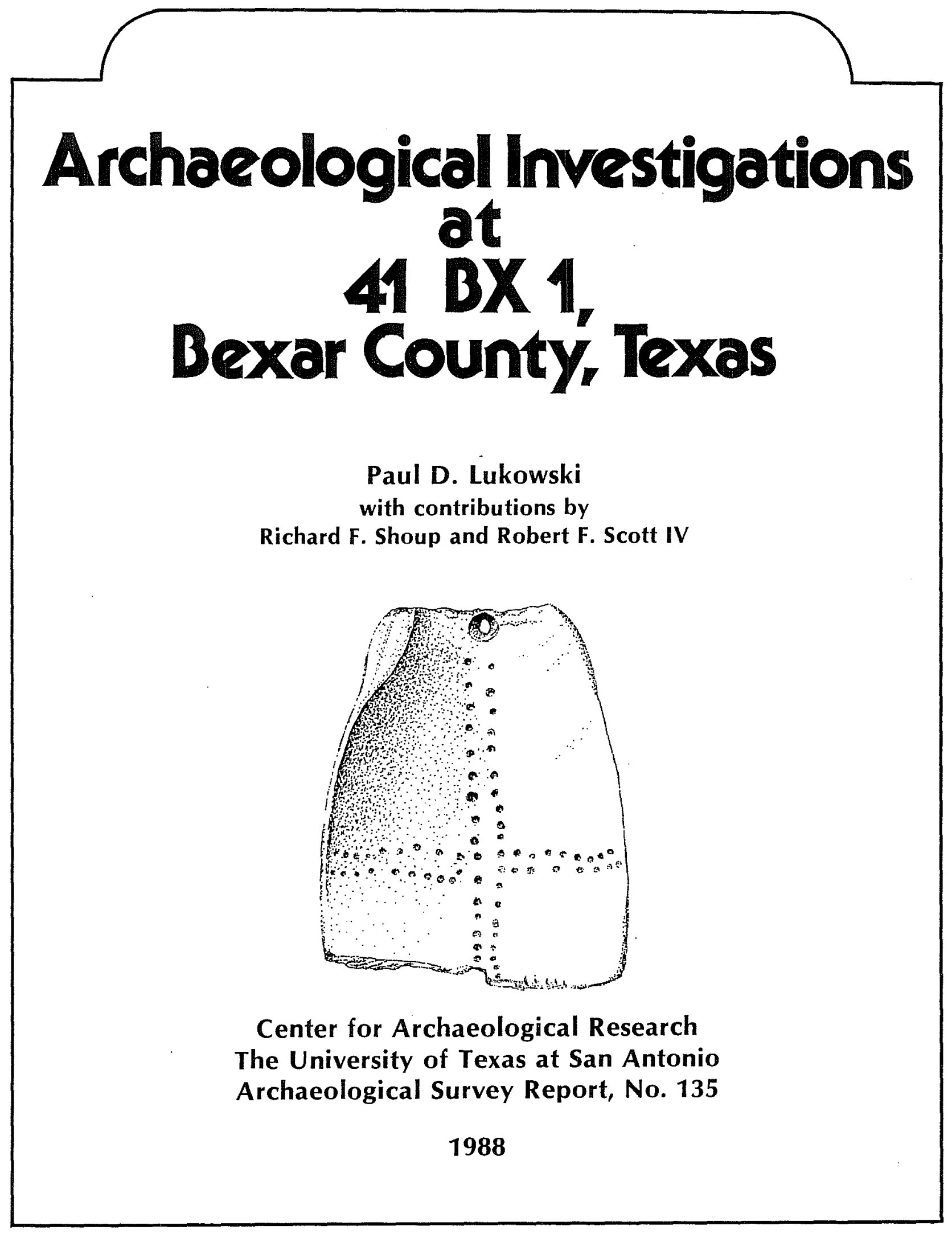






\title{
ARCHAEOLOGICAL INVESTIGATIONS AT 41 BX 1 , BEXAR COUNTY, TEXAS
}

\author{
Paul D. Lukowski \\ With Contributions by \\ Richard F. Shoup and Robert F. Scott IV \\ Texas Antiquities Committee Permit No. 220 \\ Thomas R. Hester, Principal Investigator
}

Center for Archaeological Research The University of Texas at San Antonio ${ }^{\circledR}$ Archaeological Survey Report, No. 135 
The following information is provided in accordance with General Rules of Practice and Procedure Chapter 41.11 (Investigation Reports), Texas Antiquities Committee:

1. Type of investigation: archaeological mitigation at the Olmos Dam site (41 BX 1);

2. Project name: Olmos Dam site (41 BX 1);

3. County: Bexar County, Texas;

4. Principal investigators: Thomas R. Hester, principal investigator; Jack D. Eaton, coprincipal investigator;

5. Name and location of sponsoring agency: San Antonio River Authority, San Antonio, Texas;

6. Texas Antiquities Committee Permit No. 220;

7. Published by the Center for Archaeological Research, The University of Texas at San Antonio, San Antonio, Texas 78285-0658, 1988.

A list of publications offered by the Center for Archaeological Research can be obtained by sending $\$ 1.00$ to the Center for Archaeological Research, The University of Texas at San Antonio, San Antonio, Texas 78285-0658. 


\begin{abstract}
Excavations at site $41 \mathrm{BX} 1$, located behind the Olmos Dam in San Antonio, Texas, were funded by the San Antonio River Authority. The excavations resulted in the documentation of a Late Archaic cemetery and Early to Late Transitional Archaic occupations. Thirteen human burials, accompanied by a variety of grave offerings, including deer antlers and marine shell ornaments, were radiocarbon dated 1680 B.C. (maximum date) to A.D. 260 (minimum date). In addition, two distinct occupational areas, horizontally separated from the cemetery, were investigated.
\end{abstract}

In conjunction with the excavations, final resource management negotiations resulted in mitigation measures of avoidance and protection for the remaining portions of the site. 


\section{TABLE OF CONTENTS}

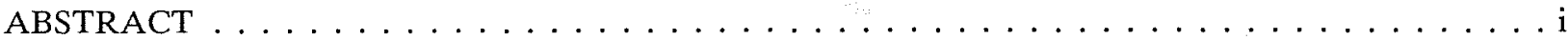

LIST OF FIGURES $\ldots \ldots \ldots \ldots \ldots \ldots \ldots \ldots \ldots \ldots \ldots \ldots \ldots \ldots$ iv

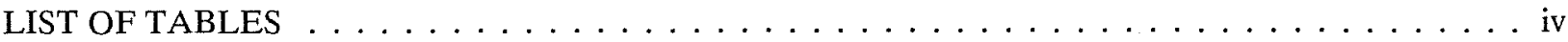

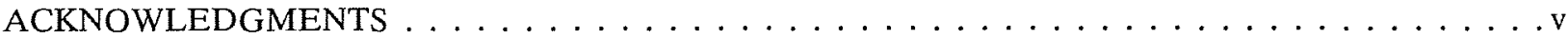

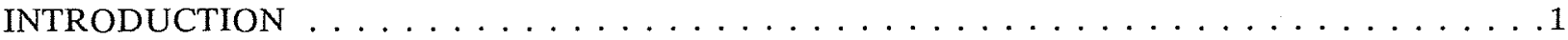

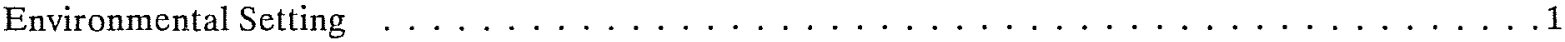

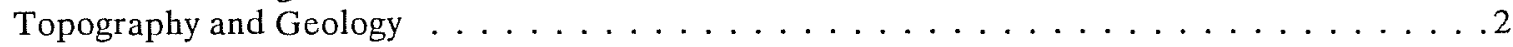

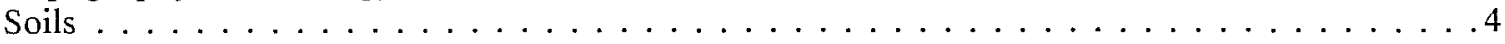

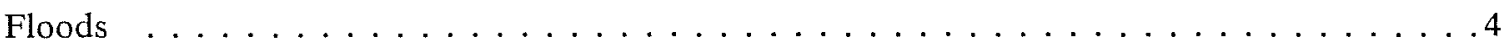

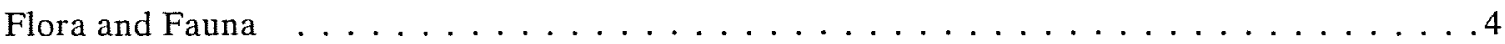

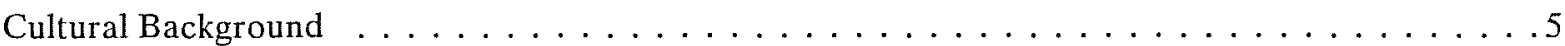

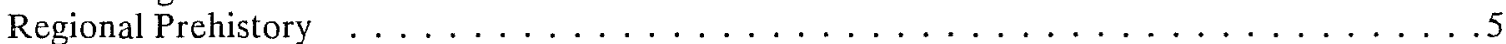

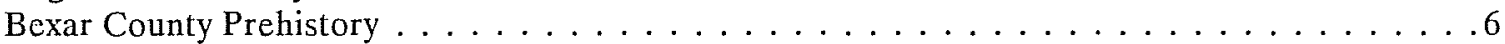

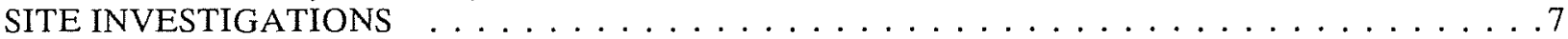

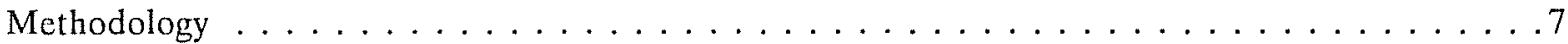

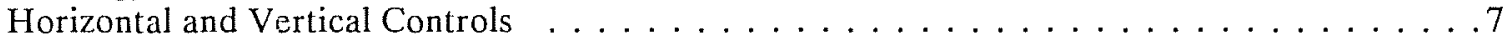

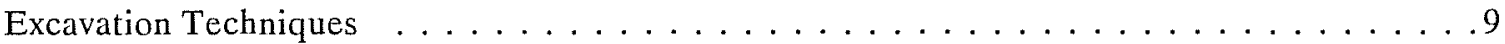

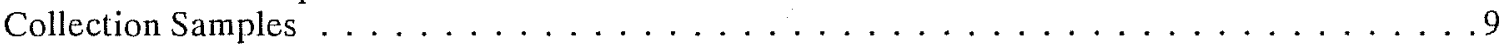

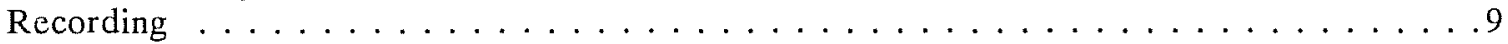

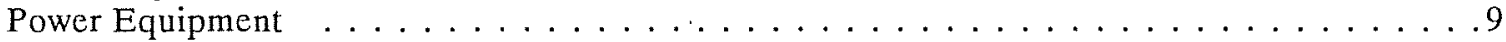

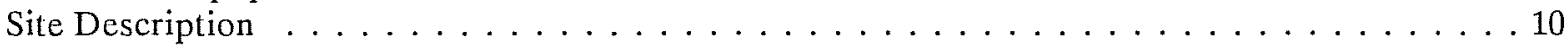

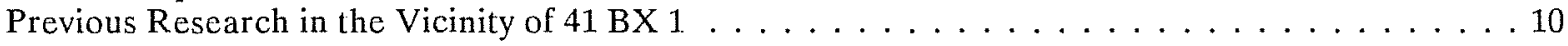

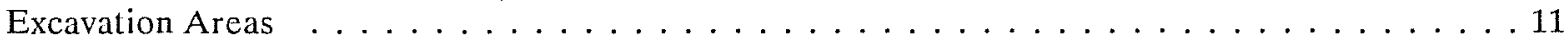

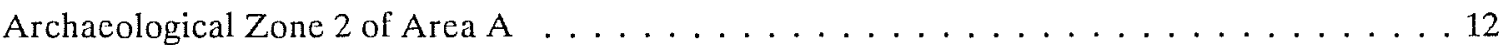

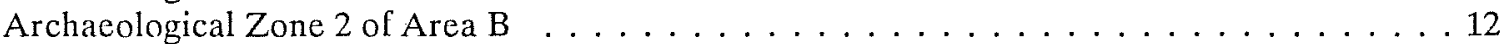

Archaeological Zone $3 \ldots \ldots \ldots \ldots \ldots \ldots \ldots \ldots \ldots$

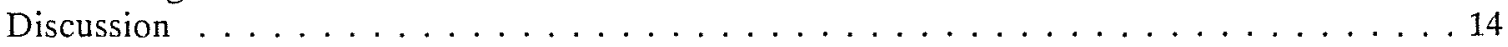

Radiocarbon Dates . . . . . . . . . . . . . . . . . . . . . 15

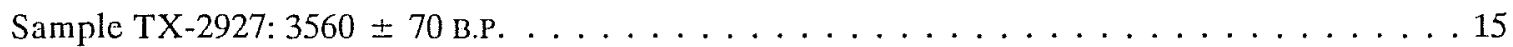

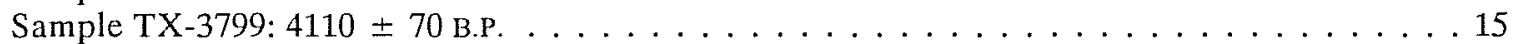

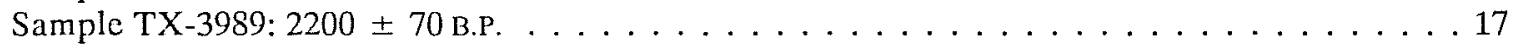

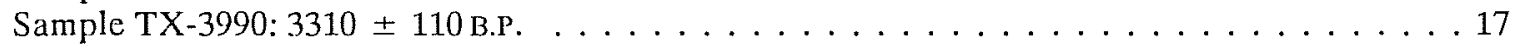

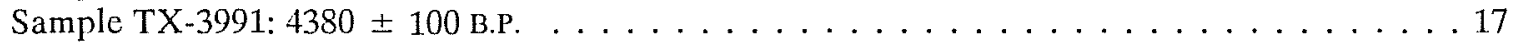

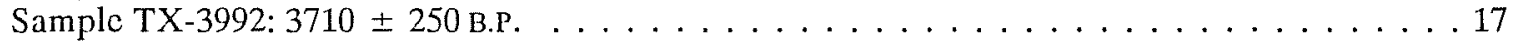

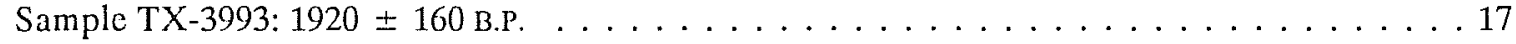

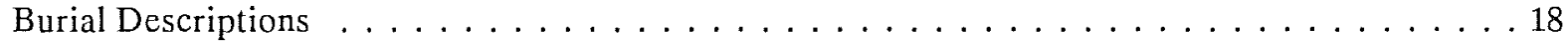

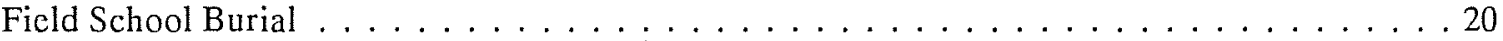

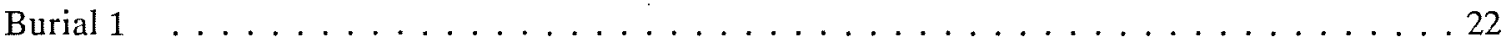

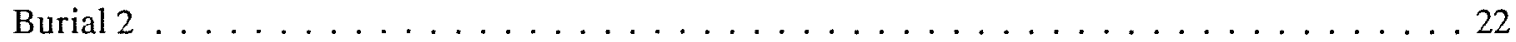

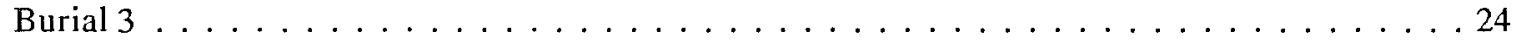

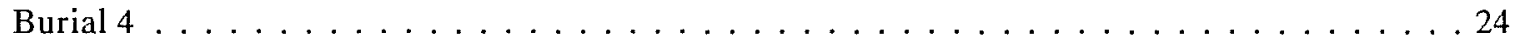

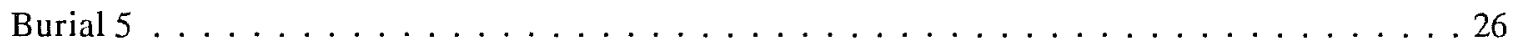

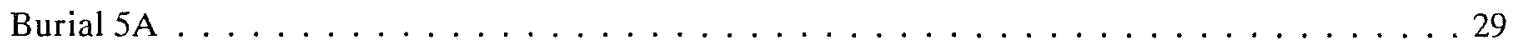

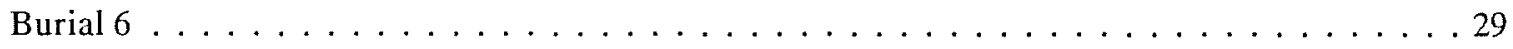

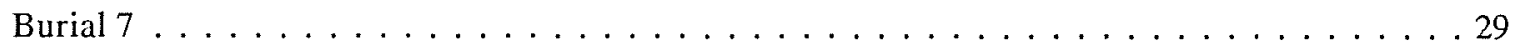

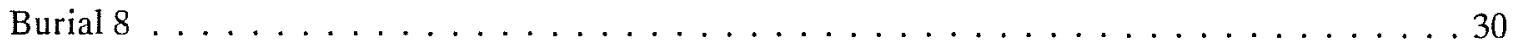

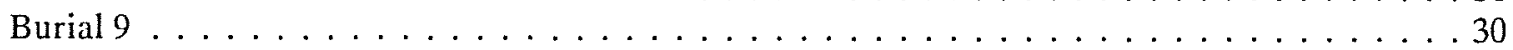

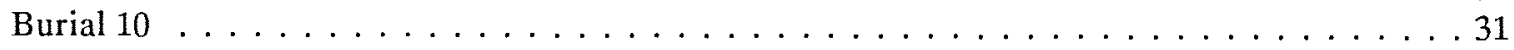

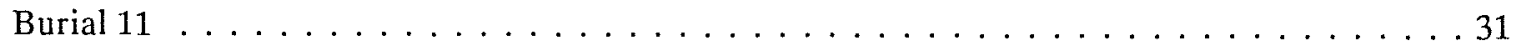

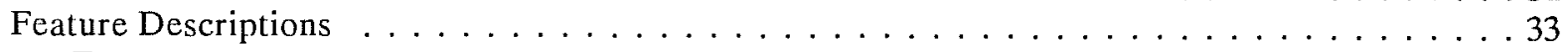

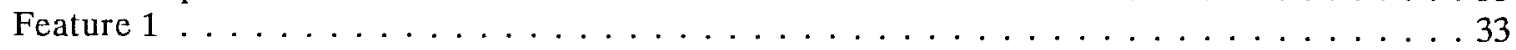

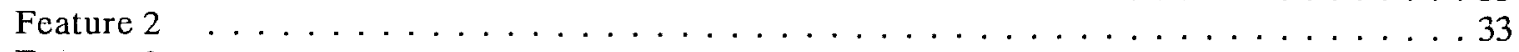

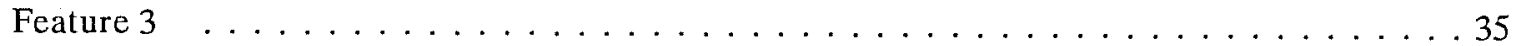




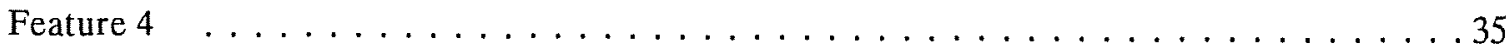

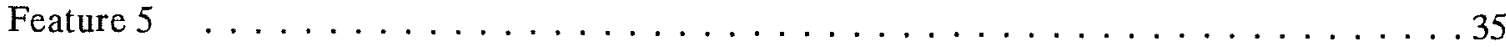

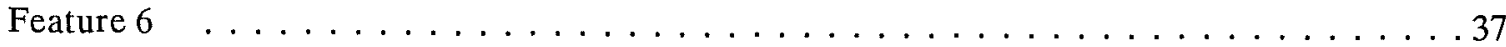

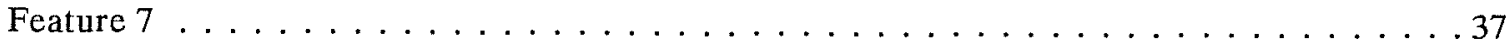

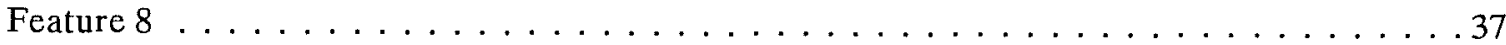

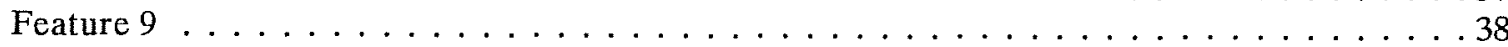

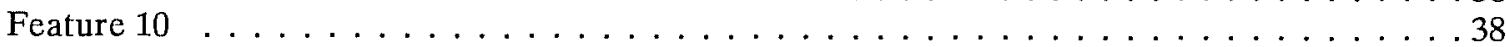

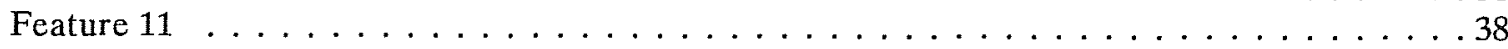

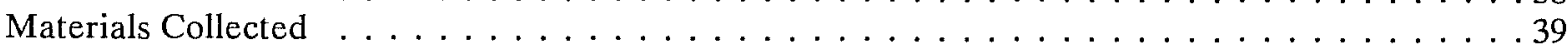

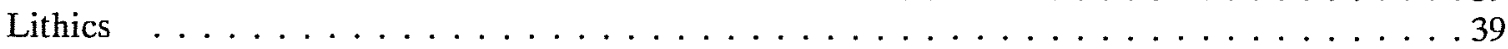

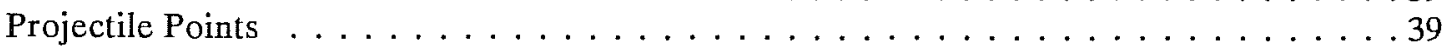

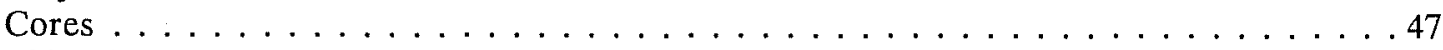

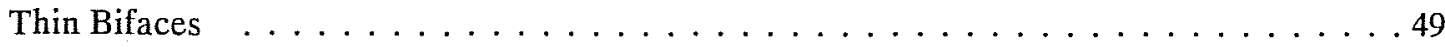

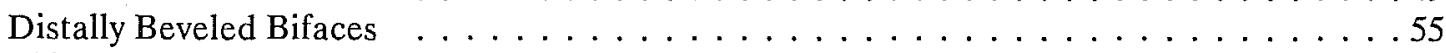

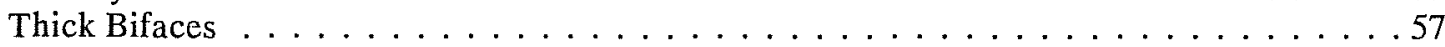

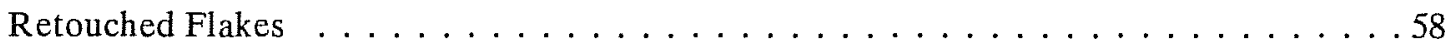

Retouched Chips . . . . . . . . . . . . . . . . . . . 63

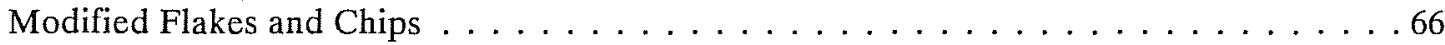

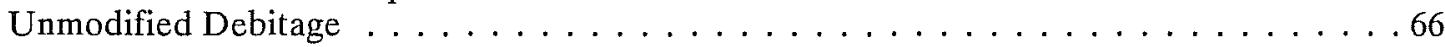

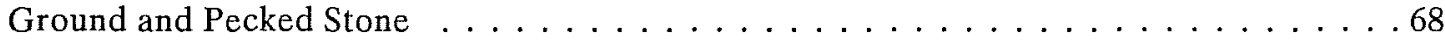

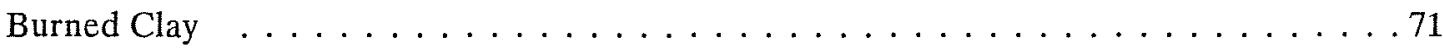

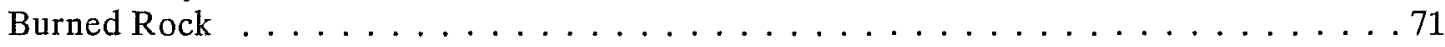

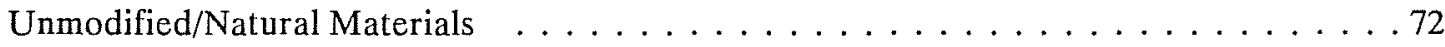

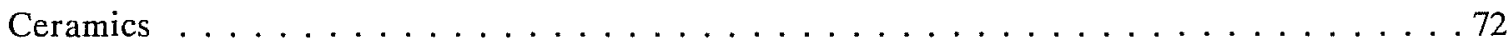

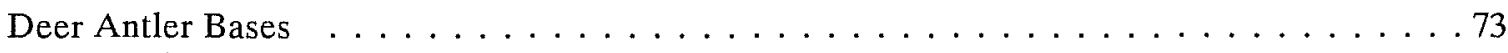

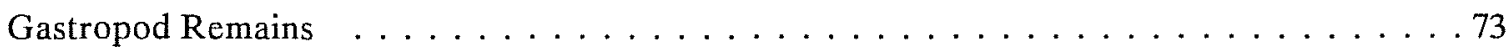

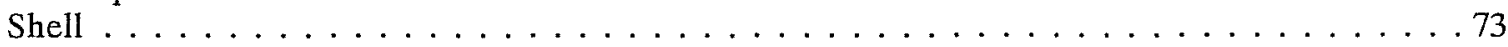

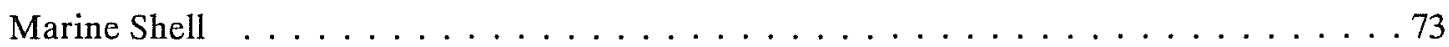

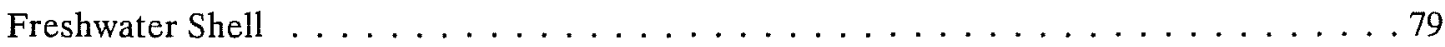

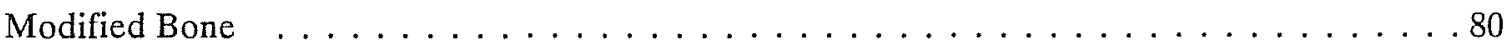

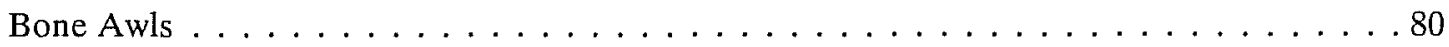

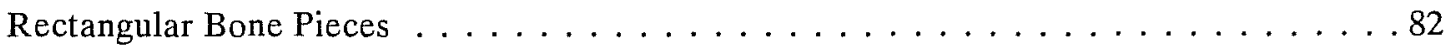

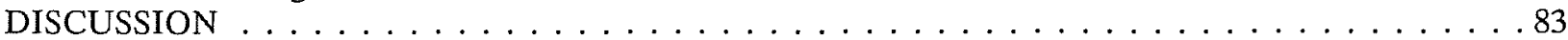

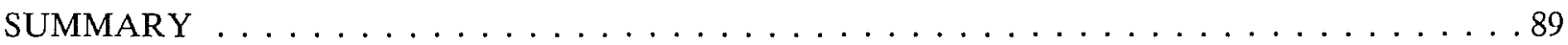

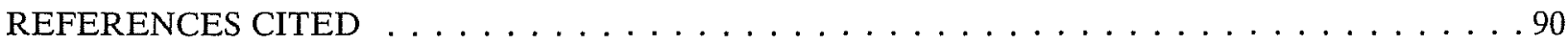

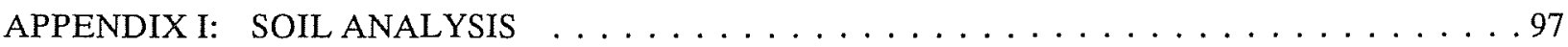

APPENDIX II: SKELETAL AND DENTAL MATERIALS (Richard F. Shoup) $\ldots \ldots \ldots \ldots 101$

APPENDIX III: PROVENIENCE OF ARTIFACTS . . . . . . . . . . . . . . . . . 115

APPENDIX IV: FAUNAL REMAINS (Robert F. Scott IV) . . . . . . . . . . . . . . 128 


\section{LIST OF FIGURES}

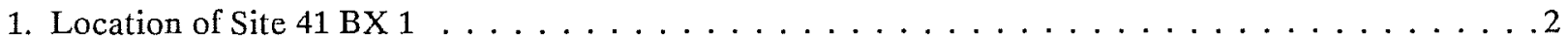

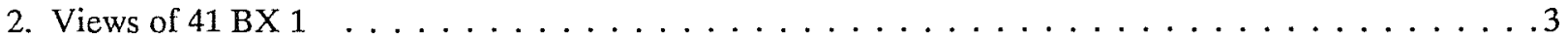

3. Topographical Map and Excavation Plan for Archaeological Zones 2 and 3 at 41 BX $1 \ldots \ldots$

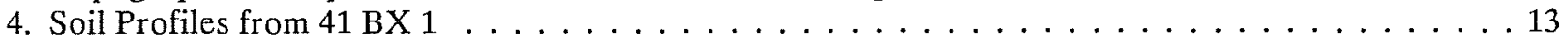

5. Radiocarbon Dates from 41 BX 1 Compared to Chronological Sequence for Central Texas . . . . 16

6. Burial Plan of Zone 2 in Area A at $41 \mathrm{BX} 1 \ldots \ldots \ldots \ldots$

7. Plan Views of the F.S. Burial, Burial 1, and Burial 7 at $41 \mathrm{BX} 1 \ldots \ldots \ldots \ldots$

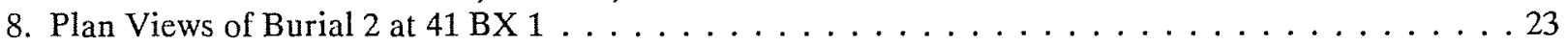

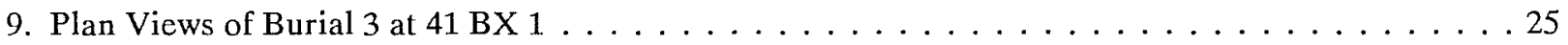

10. Plan View of Feature 2 Overlying Burials 8 and 9 , and Plan View of Burial 4 at 41 BX $1 \ldots 27$

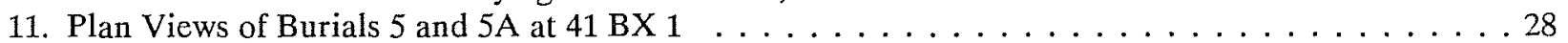

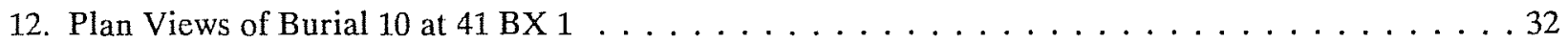

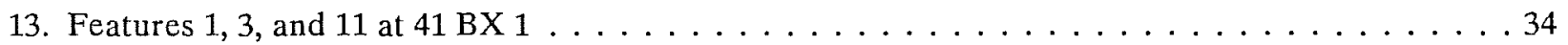

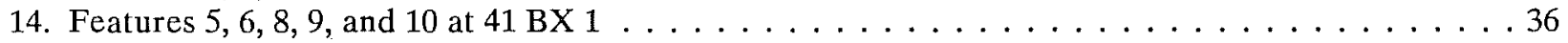

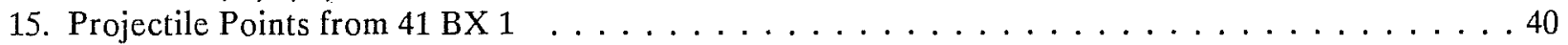

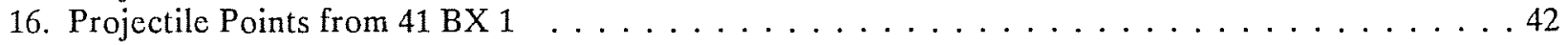

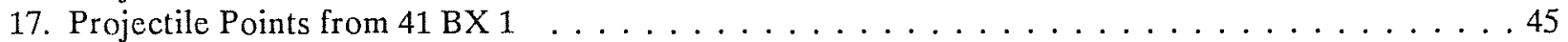

18. Miscellaneous Projectile Point Forms and Fragments from 41 BX $1 \ldots \ldots \ldots$

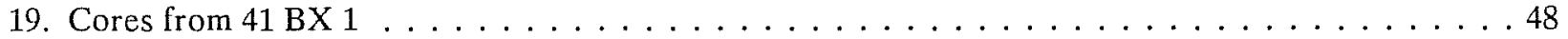

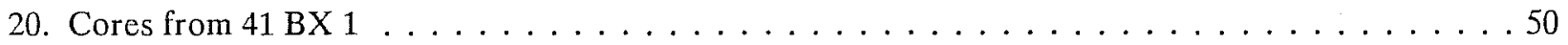

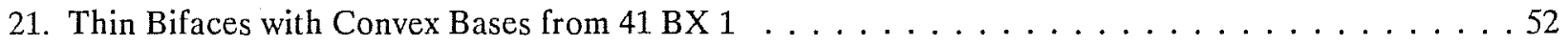

22. Thin Bifaces with Concave and Straight Bases from $41 \mathrm{BX} 1 \ldots \ldots \ldots \ldots \ldots$

23. Distally Beveled Bifaces and Thick Bifaces with a Convex Base and Convex Sides from 41 BX 1 . . 56

24. Thick Bifaces with a Straight Base, Thick Bifaces with Convex Edges, and Thick Biface Fragments

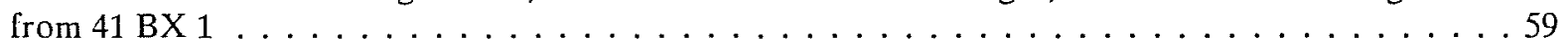

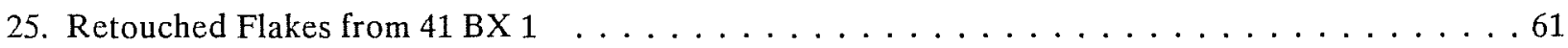

26. Retouched Chips and Modified Debitage from 41 BX $1 \ldots \ldots \ldots \ldots$

27. Grinding Slab Fragments from $41 \mathrm{BX} 1 \ldots \ldots \ldots$. . . . . . . . . . . . . . . . 69

28. Handstones, Hammerstones, and Modified Quartz Cobbles from 41 BX 1 . . . . . . . . . 70

29. Conch Pendants and Mussel Shell Pendants from 41 BX $1 \ldots \ldots \ldots \ldots \ldots$

30. Conch Pendant and Columella Pendants from 41 BX $1 \ldots \ldots \ldots \ldots \ldots \ldots$

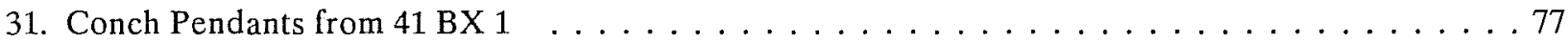

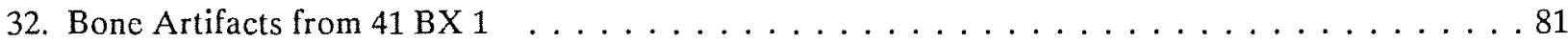

33. Bar Graph of Flake and Chip Estimates by Excavation Area $\ldots \ldots \ldots \ldots$

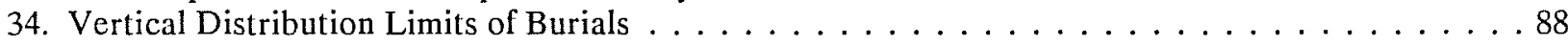

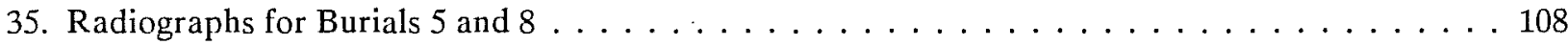

\section{LIST OF TABLES}

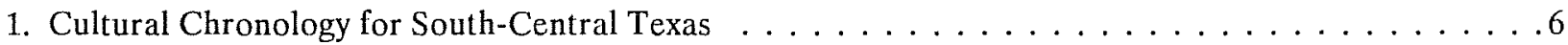

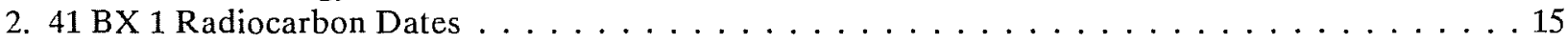

3. Soil Analysis Data from $41 \mathrm{BX} 1 \ldots \ldots \ldots \ldots \ldots \ldots \ldots \ldots$

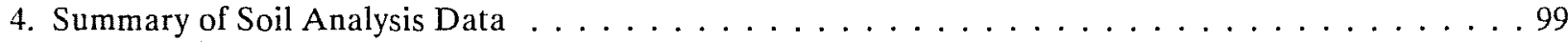

5. Estimated Stature of the Skeletal Sample from 41 BX $1 \ldots \ldots \ldots \ldots \ldots$

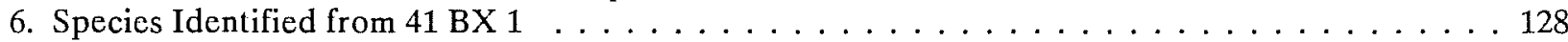

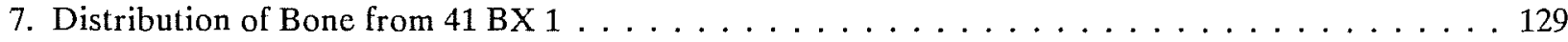




\section{ACKNOWLEDGMENTS}

The participation and cooperation of individuals from several different organizations helped to make this project possible. The sponsoring agency, the San Antonio River Authority, specifically chief engineer Dorian French, worked with the Center for Archaeological Research director, Dr. Thomas R. Hester, and associate director, Jack Eaton, and Alton Briggs of the State Historical Preservation Office from initiation of the project to its completion. Additionally, Grant Hall, acting director of the Center during a major portion of the field work phase of the project, maintained a strong interest in the author's efforts throughout the project.

Appreciated are the efforts and special talents of the field crew: Sylvia Bento, Curtis Dusek, Jody Goode, Cindy Kilty, Betty Markey, Lange Scruggs, Harvey Smith, Bob Stiba, Herb Uecker, and Karen West Scott. Additionally, the time and help generously donated by a number of volunteers during the field work are appreciated.

Contributions and services by the following people who made specialized studies of many of the materials possible are also appreciated: Robert F. Scott IV and his wife, Karen, worked with the faunal remains from the site, Richard Shoup analyzed the human skeletal remains, and Dr. Donald R. Lewis guided the soil chemistry studies.

The preparation of the draft and final manuscript was aided by Mary Lou Ellis, CAR secretary and typist; Ann Young, Mary Lehr, Anne Kerr, and Donna Rhode, typists. Sharon Quirk edited the manuscript, and Al B. Wesolowsky helped with the editing of the burial descriptions.

Finally, thanks to the interest and concern of Jack Ferguson, who discovered the burial area and brought its significance to the attention of Dr. Hester before it was accidentally destroyed. 



\section{INTRODUCTION}

During December 1979 through May 1980, archaeologists from the Center for Archaeological Research (CAR) at The University of Texas at San Antonio (UTSA) conducted archaeological excavations within the designated Archaeological Zones 2 and 3 of site 41 BX 1, located just north of the Olmos Dam in San Antonio, Bexar County, Texas. These excavations were performed for the San Antonio River Authority (SARA) by the CAR-UTSA under the terms of a letter proposal dated September 4, 1979, and Purchase Order No. 9515, dated November 28, 1979. October 12, 1979, the State Historic Preservation Officer, Truett Latimer, recommended that site $41 \mathrm{BX} 1$ be considered eligible for inclusion within the National Register of Historic Places. The excavations were authorized under terms of Texas Antiquities Committee Permit No. 220, issued October 15, 1979.

The 41 BX 1 mitigation project culminated a series of increasingly intensive archaeological research projects within the site boundaries. The initiation of borrow operations, in conjunction with a scheduled dam renovation project by the SARA, led to the accidental discovery of previously undetected significant archaeological deposits, including the discovery of a possible prehistoric cemetery. Funded testing to delimit the size and nature of these cultural deposits was conducted; subsequently, resulting in the $41 \mathrm{BX} 1$ mitigation project. The mitigation project was originally intended to free designated Archaeological Zones 2 and 3 from continued borrow operations behind Olmos Dam (Fig. 1). However, it became clear towards the end of the project that the mitigation, in its original form, would be insufficient to adequately mitigate the site. Subsequent approved cultural resource management negotiations between the Texas Historical Commission (THC), the U.S. Department of Commerce, Economic Development Administration (EDA), the CAR-UTSA, and the SARA resulted in final mitigation measures of protection and avoidance whereby borrow operations were relocated to areas outside Archaeological Zones 2 and 3. This report summarizes the data and analysis resulting from the excavation activities during the $41 \mathrm{BX} 1$ mitigation project. The archaeological resources documented herein include 13 Archaic period human burials removed from a prehistoric cemetery that provide important information on the cultural practices during that period. In addition to the burial component, two distinct Archaic occupational areas were investigated.

At present, avoidance measures that constitute the final mitigation measures for undisturbed portions of the site have left substantial portions of site $41 \mathrm{BX} 1$ intact for the future.

\section{ENVIRONMENTAL SETTING}

The environmental setting of the Olmos Basin and the adjacent areas is created by the interrelationship of the varied geology, soil, topography, climate, and biota within the region. This setting, especially the biotic makeup, has probably changed somewhat in the recent past (Inglis 1964; Story 1980). Additionally, extensive land modifications in the immediate area of $41 \mathrm{BX} 1$ have almost completely altered the surface area of the site (see Fig. 2).

Olmos Creek originates on the edge of the Edwards Plateau in northern Bexar County approximately $20 \mathrm{~km}$ upstream from its confluence with the San Antonio River. Olmos Creek is an entrenched stream within relatively deep recent terrace deposits (Barnes 1974). The watershed covers 13.79 hectares (34 square miles) and lies between the Salado Creek and Leon Creek drainages. Elevations within the watershed vary from 650 to 1180 feet above mean sea level (msl; Corps of Engineers 1972).

Olmos Creek runs in a southeasterly trending direction through the Balcones Fault Zone, ending near a series of large springs derived from a line of faults near Brackenridge Park and San Pedro Park (ibid.). The Worth and San Antonio Springs are close to the site, and several unnamed springs are just south of the dam (Fox 1975). 
This page has been

redacted because it

contains restricted

information. 


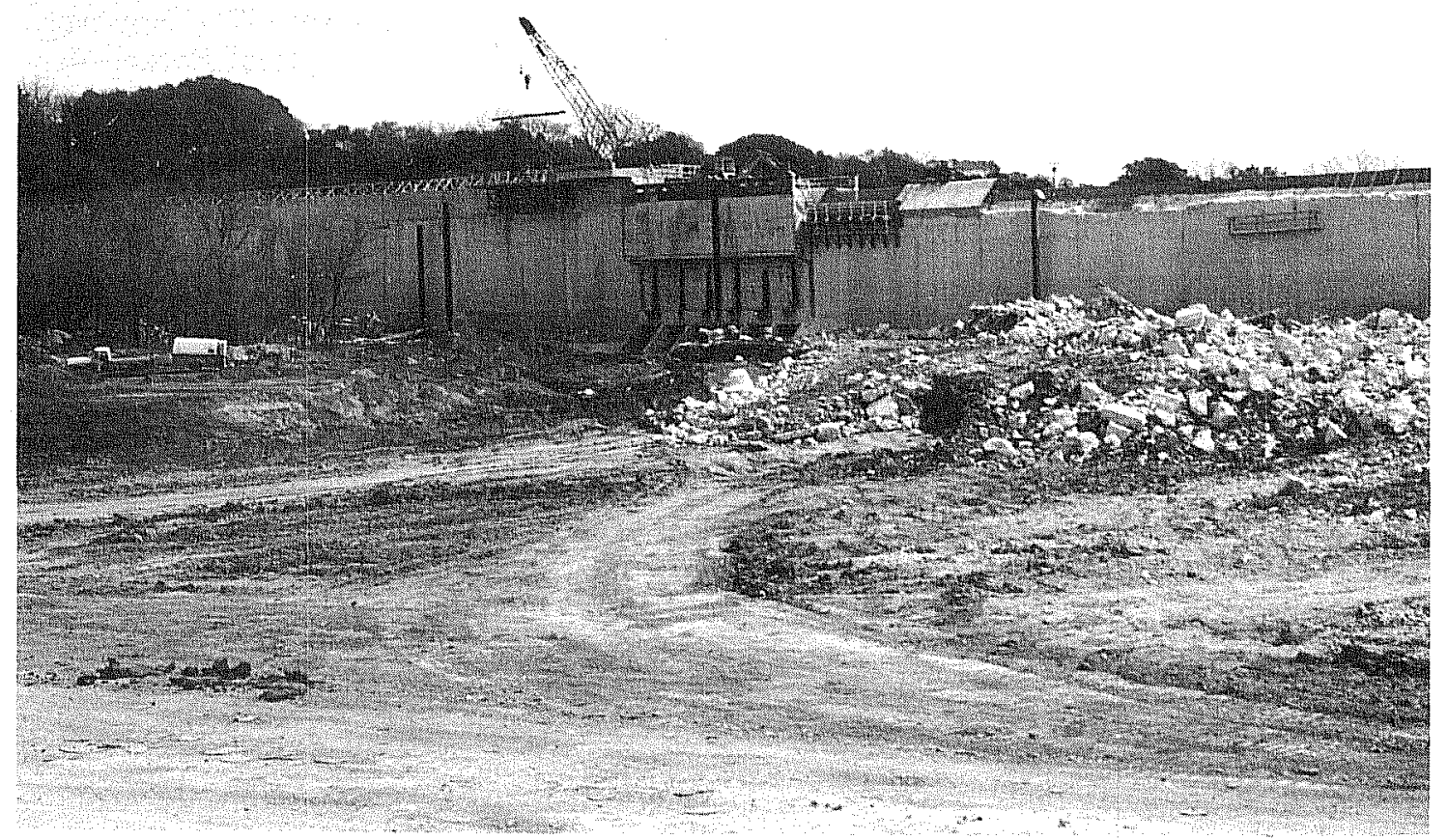

a

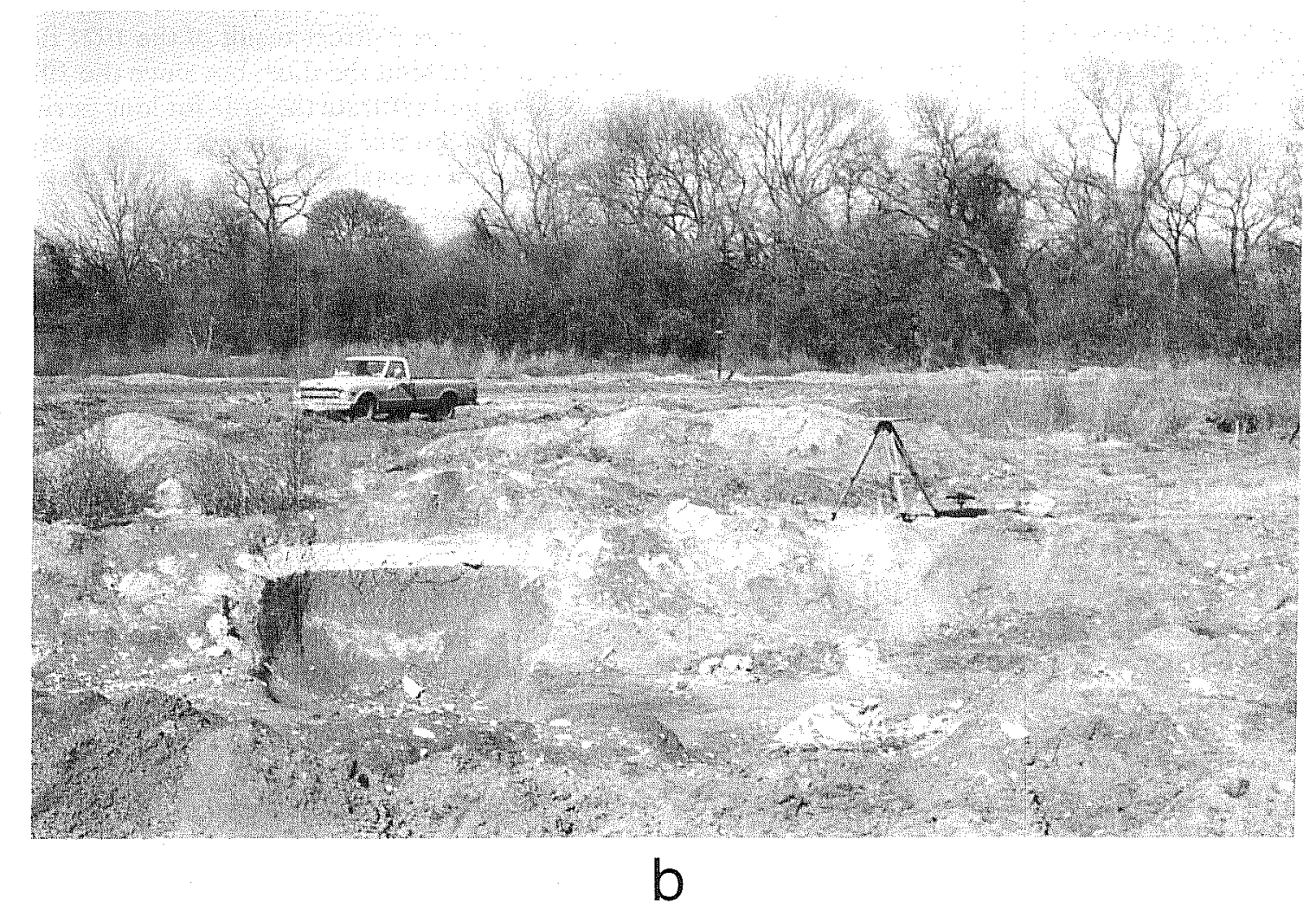

Figure 2. Views of 41 BX 1. a, looking east across borrow pit to Olmos Dam, Archaeological Zone 2 to the left of borrow pit; b, Archaeological Zone 2 of Area A looking northeast prior to excavations, Trench 22 profile on left. 
The Balcones Escarpment is the predominant geological feature of this area. The term Balcones Escarpment refers to the topographic features encountered while crossing the Balcones structural zone and is expressed by rapid changes in elevation and, thus, cannot be considered a single continuous, equally developed escarpment marking a definite boundary to the Gulf Coastal Plain (Sellards and Baker 1934). However, only a few miles to the south, the San Antonio River begins to cross the relatively level Eocene deposits characteristic of the Gulf Coastal Plain (Watts 1936; Barnes 1974).

\section{SOILS}

The soils of the Olmos Creek area are classed as azonal alluvial soils, which lack distinct, genetically related horizons because of their relative youth. They are only slightly modified by the soil forming process (Taylor, Hailey, and Richmond 1966). Soils within the floodplain are listed as Frio and Trinity soils of the Crawford-Bexar Association. Colors are dark gray to dark grayish brown near the surface, becoming lighter in hue with increasing depth. The soils are considered moderately alkaline (7.8-8.4 pH levels) and have a high shrink-swell capacity (ibid.). Stream channels within the Trinity and Frio soils tend to be poorly defined and of small capacity. Soils are generally three to five feet deep and typically subject to flooding at least once a year. Some areas may experience scouring, shifting, or a thin deposition of sediments (Taylor, Hailey, and Richmond 1966). The soil chemistry is discussed in Appendix I of this report.

\section{FLOODS}

Periodic flooding due to heavy rains in and around the Olmos Basin has been recorded since 1819 (Corps of Engineers 1972). Flooding is most likely to occur in the area during the spring or fall seasons but can occur at any time. Generally, flooding is due to long heavy rains, but localized thundershowers can also produce floods. Based on information recorded for this area, major floods are known or suspected to have occurred on Olmos Creek during the following years: $1819,1865,1880,1899$, two in 1913, 1921, 1935, two in 1946, and 1957. Olmos Dam was constructed in 1925, prompted by, and as a direct result of the 1921 flood (ibid.). Its sole purpose is flood prevention. Water is not usually held behind the dam, but since the 1920s, even minor floods have tended to temporarily pool behind Olmos Dam and saturate the area for long periods. Heavy rains, during the field season in December 1979, resulted in backwater that completely submerged the site for a full day, and left the bare clay soils of the reservoir area impassable for days. Conversely, as the soil has a high shrink-swell capacity, deep vertical cracks may appear on the site during extended dry seasons.

\section{FLORA AND FAUNA}

San Antonio is near the boundaries of three separate biotic provinces. Blair (1950) has identified these biotic provinces as the Balconian, the Texan, and the Tamaulipan. Gradual mixing and interdigitation of the flora and fauna within this area prevent drawing exact boundaries, but generally geologic and soil associations are used to separate the three biota.

The most prominent of these boundaries is the southern and eastern line of the Balcones Fault Zone and the western limits of the Eocene deposits characteristic of the Gulf Coastal Plain. The Edwards Plateau region of Texas (the Balconian Biotic Province) is characterized by an oak-juniper forest (Gould 1969; Arbingast et al. 1976). Stream valleys in the Balconian Biotic Province support a mesic forest of elm, pecan, hackberry, and large oak trees (Blair 1950).

In the Gulf Coastal Plains, the Texan and Tamaulipan biotas meet at a line of pedalfer and pedocal soils (ibid.). The pedalfer soils (the Texan Biotic Province) are generally east of the San Antonio River and support tall grasslands of the Blackland Prairies and a hickory-oak forest. Stream valleys in the Texan Biotic Province support a mesic forest of oak, pecan, hackberry, and other trees. 
The Tamaulipan Biotic Province is south and west of the Edwards Plateau and the San Antonio River and represents the most arid environmental setting of the three biotas. This area is characterized as brushland with whitebrush, acacias, mimosa, and mesquite common (Blair 1950). Stream valleys generally support large oak forests. Inglis (1964), utilizing early descriptions by travelers on the vegetation of the Rio Grande Plain between 1675 and 1900, indicates that the area to the east of the San Antonio River was an open plain of oak savanna prior to about 1850 . To the west of San Antonio was an open prairie with infrequent mesquite and brush. Travelers commented on the amount of deer present in the open plains and reported bison and antelope close to or in Bexar County (Inglis 1964). Wild turkey was observed in the stream valleys.

Later in time there is some indication of increasingly brushy vegetation cover, possibly originating around the outskirts of populated areas like San Antonio. Inglis (1964:101) states that whereas the area around San Pedro Springs in San Antonio was reported to have contained only sparse stands of mesquite during the early Spanish period, by the 1850 s the area was covered with dense brush.

\section{CULTURAL BACKGROUND}

\section{REGIONAL PREHISTORY}

Traditionally, the chronological framework for the central Texas region has been based on typologically distinct projectile point sequences supported by radiocarbon dating. Suhm, Krieger, and Jelks (1954), incorporating various earlier chronological interpretations in Texas, have outlined four cultural stages and the differing economic adaptations of each (also see Shafer [1976:1-9]): the Paleo-American, the Archaic, the Neo-American, and the Historic. A more detailed regional overview was developed later by Suhm (1960).

In the 1960s modification and refinement of the cultural sequence continued. Johnson (1964) identified four subdivisions of the Archaic (termed the Early, Middle, Late, and Transitional). Later (Shafer 1963), recognition of a cultural period before the Early Archaic subdivision eventually came to be called the "Pre-Archaic" by Sollberger and Hester (1972), although the implied prehistoric lifeways inherent in the name has caused some discussion concerning the appropriateness of the term in the cultural chronological sequence (Hester 1977). See Shafer (1976:1-9) for a review of the definition of the term Archaic in Texas prehistoric studies.

Weir (1976a), in an attempt to better define the sociocultural developments within the long central Texas Archaic, proposed five phases that could be delimited on the basis of changing settlement patterns, tool kit assemblages, and environmental conditions that might reflect differing economic strategies. Although Weir's (1976b, 1979:6) phases contain essentially the same chronological diagnostics as the more traditional cultural sequence, they also made clear that the phases, overlapping in time, were not simply the result of stylistic changes in the projectile point sequence, but were indicators of cultural change and/or an adaptation within the Archaic tradition.

More recently, Story (1980), in a review of the Archaic in the Gulf Coastal Plains (utilizing data from nearby regions, including the lower Pecos River area and the Edwards Plateau), divided the Archaic into Early, Middle, and Late. Story (1980) states these divisions may be gross temporal indicators, but in doing so is able to suggest and separate differing adaptive strategies, economic bases, and settlement patterns distinguishing each period. Overall the areal indications seem to be of an Archaic tradition with increasingly complex and restricted territories.

The beginning of the Late Prehistoric is arbitrarily marked by the introduction of the bow and arrow and slightly later, ceramics. The Late Prehistoric occurs late in south Texas (as late as A.D. 1200; Montgomery 1978) or coexists with the Archaic, but begins as early as 200 B.C. in the eastern part of Texas (Story 1980). Kelley (1947) identified and described the central Texas aspect and their foci (Austin and Toyah) of the Late Prehistoric. Jelks (1962) also provides detailed information on the period. 


\section{BEXAR COUNTY PREHISTORY}

More locally oriented regional overviews for Bexar County and the surrounding counties are available. Woolford (1935) made one of the first attempts at classification of prehistoric site types for the area. Hester (1975a) has reviewed the archaeology of the San Antonio and Guadalupe River drainages (including Bexar, Caldwell, Comal, DeWitt, Gonzales, Victoria, Medina, and Uvalde Counties). Fawcett (1972) classified sites in Bexar County, noting the importance of three different archaeological zones, generally divided into the geographic zones of the Edwards Plateau, the Balcones Fault Zone, and the Gulf Coastal Plain. Other major studies within Bexar County include the Fort Sam Houston survey (Gerstle, Kelly, and Assad 1978), excavations at Saint Mary's Hall (Hester 1978, 1979), the Granberg II site, the Elm Water Hole site (41 BX 300; Katz 1987), the Panther Creek Springs site (Black and McGraw 1985), and the Paleo-Indian campsite at $41 \mathrm{BX} 57$ (Henderson 1980).

This report utilizes the cultural-historical chronological sequence presented by Gerstle, Kelly, and Assad (1978:Tables 4 and 5), slightly modified by the implications of Story's (1980) paper. The chronological sequence followed in this report is presented in Table 1.

TABLE 1. CULTURAL CHRONOLOGY FOR SOUTH-CENTRAL TEXAS

\begin{tabular}{|c|c|c|c|}
\hline Date B.P. & Period & Phase & Projectile Point Types \\
\hline \multirow{2}{*}{200} & \multicolumn{3}{|l|}{ Historic } \\
\hline & \multirow{2}{*}{ Late Prehistoric } & Toyah & Perdiz \\
\hline \multirow{2}{*}{1250} & & Austin & Scallom, Edwards \\
\hline & \multirow{2}{*}{ Late Archaic } & Twin Sisters & Ensor, Frio \\
\hline 1750 & & San Marcos & $\begin{array}{l}\text { Montell, Castroville, } \\
\text { Marshall }\end{array}$ \\
\hline 2600 & \multirow{2}{*}{ Middle Archaic } & Round Rock & Pedernales, Langtry \\
\hline 4000 & & Clear Fork & Travis, Nolan \\
\hline 5000 & Early Archaic & San Geronimo & $\begin{array}{l}\text { Bell, Gower, Uvalde, } \\
\text { Early Corner Notched }\end{array}$ \\
\hline 8000 & Paleo-Indian & & $\begin{array}{l}\text { Angostura, Plainview, } \\
\text { Folsom, Clovis }\end{array}$ \\
\hline
\end{tabular}




\section{SITE INVESTIGATIONS}

Site $41 \mathrm{BX} 1$ is located within the Alamo Heights district of the City of San Antonio, at N $29^{\circ} 28^{\prime}$ W $98^{\circ} 28^{\prime}$ on the western bank of the present (channelized) Olmos Creek. The site is situated in a cleared reservoir pooling area immediately north of the Olmos Dam. U.S. Highway 281 is just west of the site as the road crosses the southwestern edge of the dam. Nearby are Incarnate Word College and Trinity University, on either side of the southern limits of the Olmos Basin.

\section{METHODOLOGY}

The purpose of excavations at $41 \mathrm{BX} 1$ was to find and document as many burials as possible and to sample the two known occupation zones within the site. Mr. Jack Ferguson made the discovery of the cemetery, and the initial field work was conducted in June and July 1979, by the UTSA Summer Field School and the CAR (Kelly and Eaton 1979).

The UTSA Summer Field School documented the in situ presence of one human burial and other human bone closely associated with deer antler confined to Area A of Zone 2 (Fig. 3). Noted also was the presence of a nearby burned rock midden (Zone 2, Area B) and a small discrete occupational midden about $70 \mathrm{~m}$ north of the burial area (Zone 3). Backhoe trenching by Kelly and Eaton (1979) helped define the cultural concentration and the boundaries.

The subsequent field work began December 17, 1979, and continued until March 22, 1980. Approximately 337 person-days were spent in excavation and recording of the site. This was accomplished in 60 actual field days with part-time to full-time crews varying in size from three to nine people.

The field work focused on continually expanding block type excavations within the burial area in an effort to completely record as many human burials as possible. Sampling within Zone 2 of Area B and Zone 3 was carried out to aid in establishing the chronological sequence at the site and to better define the activities in the areas. Within this framework, and the given time and funding limitations, thirty-six $1-\mathrm{m}^{2}$ units were opened within Zone 2 of Area A, and a single $2-\mathrm{m}^{2}$ unit was excavated in each of the occupation areas (Zone 2 of Area B and Zone 3). A total volume of $31.1 \mathrm{~m}^{3}$ of soil was hand excavated.

Prior to the end of the field excavations, approved cultural resource management (CRM) negotiations between the THC, CAR-UTSA, EDA, and SARA resulted in a final mitigation plan of site protection (documented in a letter from Dorian French, chief engineer SARA, 1980).

\section{HORIZONTAL AND VERTICAL CONTROLS}

A metric grid system aligned on magnetic north was established for horizontal control. A permanent marker consisting of a nail set in concrete was placed just west of the Zone 2 boundaries and designated E1000 N1000 (reads east $1000 \mathrm{~m}$, north $1000 \mathrm{~m}$ ). Additionally, two orientation points along the north-south base line were placed in concrete. Temporary markers were used for east-west orientation points. Subsequent construction activities have removed the south and east orientation points. Unit designations were assigned based on the coordinates of the southwest corner of each unit.

A plane table topographic map of the site area was drawn. Site elevations were determined from an arbitrary vertical datum set by driving a nail into the trunk of an elm tree on the western banks of Olmos Creek. Elevation at that point was an assumed $100 \mathrm{~m}$. Other points recorded as secondary vertical datums include the grid marker E1000 N1000, the base of an abandoned power line structure near the flood gates of the dam, and an unprovenienced concrete datum established for convenience just southeast of the cemetery excavations. Mean sea level was recorded utilizing points established on the face of the dam by the SARA. 
This page has been

redacted because it

contains restricted

information. 


\section{EXCAVATION TECHNIQUES}

Excavation blocks were initially $1-\mathrm{m}^{2}$ units, but this was later expanded into $2-\mathrm{m}^{2}$ units. In areas where loose fill from the borrow operations overlaid intact deposits, these disturbed soils were either quickly examined by hand or screened before discarding. Undisturbed soils were removed in $10-\mathrm{cm}$ levels. Soils were passed through a $1 / 4$-inch mesh hardware cloth screen. All recognized cultural materials were saved. Burned rock for unit-levels was generally weighed, counted in the field, and then discarded. Excavations were initially done with trowels in the burial area; however, as project members became increasingly familiar with the site deposits and burial area, shovels were used wherever possible. Trowels, dental tools, split cane, and brushes were used as deemed necessary on cultural features and burials. Some of the burials were field treated with gelva (varying from 4:1 to 7:1 mixtures). On a few occasions, infant and adult burials were removed in blocks or portions (head or pelvis), and the surrounding matrix was taken to the CAR-UTSA laboratory.

\section{COLLECTION SAMPLES}

Soil samples were taken from features and burials, and continuous soil profile column samples were taken from each excavation area. General matrix samples (filled \#10 paper bags) and smaller samples were collected with clean trowels and placed in plastic bags for use in special soil chemistry or phytolith analysis. Charcoal samples were taken wherever sizable amounts of charcoal were noted. Ocher stains around burials were also collected.

\section{RECORDING}

Unit-level forms were completed for all excavations. Artifacts recorded in situ most commonly included diagnostics and items possibly associated with features or burials. Plan views and profiles were drawn as necessary for features, walls, and unit-levels. Twenty-eight rolls of black and white film and 14 rolls of color slide film were exposed at the site for recording purposes. A daily field log was kept. All recovered materials and other data pertaining to site $41 \mathrm{BX} 1$ are permanently stored at the CAR-UTSA laboratory.

Features and burials were treated independently of unit-levels as they were encountered. Generally each was pedestaled, exposed, recorded, sampled, and then removed. Burial recording followed methods and terminologies outlined by Sprague (1968) and Ubelaker (1978). Burial forms were adapted and only slightly modified from previously prepared forms utilized by Barbara Butler (North Texas State University) and Grant Hall (1981). Field identification of human bone was based on work by Bass (1971) and Brothwell (1972).

\section{POWER EQUIPMENT}

A backhoe with a front end loader and a small tractor front end loader supplied by the SARA were used during portions of the field work. Several of the backhoe trenches opened in 1979 by Kelly and Eaton (1979) were reopened by the backhoe and cleaned to facilitate profile checking and clarification. One new backhoe trench (T-24) was excavated at the site. An area of overburden, consisting of yellowish clay marl (averaging $50 \mathrm{~cm}$ or less in thickness), was completely stripped off the area lying between trenches 14 and 20 and south of trench 19.

Backfilling at the end of the project involved clearly delineating the excavated areas through the use of a different color or texture of soil. The backfilling process was recorded in the daily notes. After all excavation units and trenches were backfilled, the site area was slightly contoured to an approximate slope of 3:1 along the edge of the old borrow cut to prepare for seeding and to provide erosional protection as outlined in agreements between the CAR-UTSA, THC, and SARA (letter from Dorian French, April 1, 1980). 


\section{SITE DESCRIPTION}

Site 41 BX 1 is located within floodplain deposits of Olmos Creek less than a mile from its junction with the headwaters of the San Antonio River. The site area begins south of the first unnamed tributary north of the dam and extends southward to the dam face. Previous research indicates that sites 41 BX 291 and 41 BX 24 may be related to 41 BX 1 (Fox 1975; Brown 1977; Assad 1978; Katz 1987).

Extensive modification of the land surface since the 1920s makes assessment of the original site setting difficult. A topographic map, completed for the area prior to construction of the Olmos Dam, is the best available indicator of the original surface topography. This map shows a relatively flat floodplain, with Olmos Creek running along the eastern edge of the floodplain.

Channelization of Olmos Creek, away from its original course along the eastern edge of the floodplain to its present location toward the flood gates of the dam, undoubtedly resulted in the destruction of large eastern portions of the site. Entrenching for the dam foundations (up to 40 feet deep) also destroyed portions of the site (Orchard and Campbell 1954); although some intact deposits are known to occur within $15 \mathrm{~m}$ of the north face of the dam (field notes on file, CAR-UTSA, 1980).

A yellowish marl, possibly Pecan Gap Chalk (Barnes 1974), covers large areas of the site (Assad 1979; Kelly and Eaton 1979). It is believed that this material represents fill from the dam foundation excavations that was spread out over the cleared reservoir area. The combination of clearing and filling has, in effect, created a situation analogous to a geological unconformity. Orchard and Campbell (1954) note that farming activities on either side of the dam may have resulted in the loss of 12 to 18 inches of topsoil in the area. However, Suzanna Katz (personal communication) has stated that plow zone disturbance is confined to the upper 10 to $15 \mathrm{~cm}$ at site $41 \mathrm{BX} 291$ nearby. In the 1950s, development of a golf course driving range may have caused further site damage (Orchard and Campbell 1954). Borrow operations in 1979 and 1980 removed soil in varying depths (all culturally sterile zones) from all but the designated archaeological zones (Assad 1979; Kelly and Eaton 1979).

Most of the proposed borrow area has been cleared of all woody vegetation. A few recent elm trees are along the channelized portion of the creek, and grass and forbs are in the open areas. Immediately off the site, to the north and south of the dam, elm, hackberry, oak, pecan, persimmon, mesquite, acacia, cacti, grasses, and weeds occur in moderately dense concentrations. Small oak trees and grasses dominate the rocky limestone hills on either side of the basin.

\section{PREVIOUS RESEARCH IN THE VICINITY OF 41 BX 1}

Previous research in the Olmos Basin prior to the present project includes the documentation of extensive collections from local citizens who have known about and visited the basin since the 1920 s, and more recently (beginning in 1974), a series of public service and contract-related archaeological projects.

A local collection from the polo field at Brackenridge Park (41 BX 264) was consulted and was donated to the Witte Museun by Bob Dumphy (Katz and Fox 1979). A small collection of artifacts and information on site descriptions and locations on the Incarnate Word College property just south of the Olmos Dam was shared by C. D. Orchard, Harvey Smith, and A. S. Collier with Anne Fox during her survey of the area. In this survey, Fox (1975) identified eight discrete prehistoric concentrations between Hildebrand Road and the south end of Olmos Dam. Of particular interest is the A. S. Collier collection, documented by Hester (1975b:20), which includes a variety of Paleo-Indian points (Clovis, Plainview, Golondrina, and Angostura), and Archaic points (Bell, Ensor, Fairland, Frio, Marcos, Langtry, and Pedernales) that represent "a mixture of stemmed central Texas" points, and unstemmed forms (Catán, Carrizo, Desmuke, and Tortugas) more characteristic of south Texas. Additionally, a boat-stone fragment was included in the collection. A variety of Paleo-Indian points and southwestern pottery types from the $41 \mathrm{BX} 1$ area was reported by C. D. Orchard (Orchard and Campbell 1954, 1960). Mr. Brentano C. Harnish (Assad 1979:Appendix) reported Golondrina, Carrizo, and Castroville point types from 41 BX 1. Mr. Jack Ferguson of San Antonio, who 
discovered the endangered cemetery at $41 \mathrm{BX} 1$, donated a substantial portion of his skeletal collection to the CAR-UTSA for study.

In 1974, the first of a series of contract and public service projects was initiated in the area. Luke (1974) did surveying and testing for the Texas State Department of Highways and Public Transportation at locations peripheral to 41 BX 193, 41 BX 24, and 41 BX 1. At a site near 41 BX 1, a Perdiz and a Granbury (joshua variety; cf. Jelks 1962:35) were the only diagnostics recovered. Luke (1974) suggested that the area was a lithic manufacturing area where tools were roughed out but not finished.

In 1976, Suzanna Katz investigated sites 41 BX 24 and 41 BX 291. These two sites are the closest recorded sites to $41 \mathrm{BX} 1$ and may be related to it. Late Prehistoric occupations at the two sites include Perdiz and Scallorn points and a bone-tempered pottery sherd; additionally there was some indications of a Late Archaic occupation (Ellis-like, Ensor-like, and Frio dart points). Soil profiles at the two sites seem to indicate a shallower cultural deposit (15-40 cm deep) than the relatively deep cultural deposit characteristic of $41 \mathrm{BX} 1$.

In 1977, a series of contracts was awarded to the CAR-UTSA specifically involved with planned Olmos Dam modifications (Brown 1977; Assad 1978, 1979; Kelly and Eaton 1979). Initial surface survey and shovel testing by Brown (1977), for proposed alternate routes for roadways at Olmos Park, indicated that heavy surface disturbance had destroyed most of $41 \mathrm{BX} 1$. Assad (1978) carricd out additional testing related to Brown's 1977 survey on the margins of site 41 BX 291. Assad concluded that 41 BX 291 was outside the impacted area and noted extensive disturbance of the upper $60 \mathrm{~cm}$ of deposits.

Assad (1979:Fig. 1) later directed limited testing within the proposed 16-acre Olmos borrow area within the $41 \mathrm{BX} 1$ area. At that time, 13 backhoe trenches were placed in widely scattered locations around the site. Testing revealed deep soil deposition throughout the site area, but heavily disturbed or missing upper soil zones were also reported. Very light cultural deposits occurred in all but one area (Archaeological Zone 1) which was marked as inaccessible for borrow fill due to its archaeological significance.

During the course of borrow operations at the site in 1979, Mr. Jack Ferguson visited the area and discovered human skeletal remains and indications of an occupation area. Mr. Ferguson contacted Dr. T. R. Hester, director of the CAR, and reported his findings, which resulted in the temporary halt in construction activities in the area. At that time, the UTSA Summer Field School (at site 41 BX 271 and directed by Dr. T. R. Hester) conducted surface collections and test excavations to help assess the exposed cultural deposits. Significant amounts of skelctal material, Late and Middle Archaic diagnostics, a burned rock midden, and portions of an in situ burial were recorded at that time.

Funding for additional testing was then provided by the SARA, and Thomas C. Kelly (Kelly and Eaton 1979) directed a project to delimit the boundaries around the exposed material. Ten backhoe trenches were excavated and profiled during that time, indicating a depth of approximately $1.5 \mathrm{~m}$ for the cultural materials. As a result of this work, Archaeological Zones 2 and 3 (Fig. 3) were designated as inaccessible for borrow activities, and a protection plan was proposed for these areas.

\section{EXCAVATION AREAS}

A total of 23 backhoe trenches was excavated prior to the current project. Soil profiles, representative of the various areas within the 16 acres originally designated as the borrow zone within $41 \mathrm{BX} 1$, have been described by Assad (1979). Further, a discussion of the soil characteristics within specific areas of Archaeological Zones 2 and 3 has been provided in a report by Kelly and Eaton (1979). Other works by Assad (1978) and Katz (ms.) at nearby sites on the immediate south side of the Olmos Dam (in the vicinity of $41 \mathrm{BX} 24$ ) provide additional data on the soil and cultural deposits within the Olmos Basin.

Archaeological Zones 2 and 3 reference those horizontal areas designated as subdivisions of the site by Assad (1979) and Kelly and Eaton (1979). The term soil zone describes the various soil horizons and cultural strata identified in the vertical profile descriptions. 


\section{ARCHAEOLOGICAL ZONE 2 OF AREA A}

Archaeological Zone 2 of Area $\mathrm{A}$ is identified as the burial component of the site. Area A consists of the excavated units contained between the grid lines N994 to N1004 and E1010 to E1016. The units were placed along the edge of the borrow cutbank that first exposed the burial features (Fig. 2,a). Four soil zones were identified. Soil profiles for Archaeological Zones 2 and 3 are shown in Figure 4.

Soil zone 1 is a recent strata resulting from dam construction activities in the 1920s. Prior to mechanical removal of the zone, it was approximately $50 \mathrm{~cm}$ thick $(99.80-99.30$ in elevation). The zone consists of a culturally sterile yellowish, compact marl with small limestone gravel inclusions, apparently representing fill removed from the dam foundation excavations. This marl is overlain by a thick layer of yellowish gray, silty, flood pool sediments containing very recent historic artifacts. Because the fill was removed mechanically prior to excavations, the profile in Figure 4 does not show the original extent of the soil zone.

Soil zone 2 represents the uppermost level of undisturbed deposits in Area A. Although not verified, it is believed that portions of the cultural record may have been removed during dam construction. The zone is approximately $80 \mathrm{~cm}$ thick ( 99.30 to 98.50 in elevation). Soil within the zone is a dark grayish brown, very compacted clay loam. Artifactual material was sparse, but burned rocks, bone fragments, charcoal and ocher flecks, small baked clay nodules, lithic artifacts and debris, and snail shells were noted.

Soil zone 3 is a broad transitional area between soil zones 2 and 4 . Soil zone 3 is a brown, silty clay loam, which is characteristically darker in hue and higher in clay content towards the surface. The boundary between soil zones 2 and 3 was smooth and gradual and difficult to identify by hand excavations. The zone (98.50-97.70 in elevation) occurs from 80 to $160 \mathrm{~cm}$ below the undisturbed soils (the top of soil zone 2). The archaeological deposits (burned rocks, bone fragments, baked clay nodules, charcoal and ocher flecks, lithic materials, snail shells, mussel shell fragments) were densest within this zone. All of the cultural and burial features occur within this zone or are very closely associated with it.

The lowest identified zone in Area A is soil zone 4. It is a light brown, compacted silty to sandy loam with small grayish calcareous deposits throughout. The contact between soil zones 3 and 4 is a smooth, gradual boundary. Archaeological deposits included burned rocks, bone fragments, lithic artifacts and debitage, snail shells, and mussel shell fragments.

\section{ARCHAEOLOGICAL ZONE 2 OF AREA B}

Archaeological Zone 2 of Area B was identified by the UTSA Summer Field School as a burned rock concentration approximately $20 \mathrm{~m}$ east of the burial component (Fig. 3). Area B investigations consist of a profile drawing, surface collections, and Unit E1029 N1002. Area B contained the only recognized burned rock midden at the site. This area was heavily disturbed by borrow removal.

Soil zone 1 was removed prior to excavations because of its disturbed surface; it was previously recorded by Kelly and Eaton (1979) and the UTSA Summer Field School. The soil is a brown alluvial topsoil about $23 \mathrm{~cm}$ thick, underlain by a 34-cm-thick deposit of yellow clay fill. This recent deposit is clearly related to soil zone 1 of Area A.

Soil zone $2 \mathrm{~A}$ is an undisturbed, compacted silty clay loam, dark grayish brown, and ca. $30 \mathrm{~cm}$ thick. Soil zone $2 \mathrm{~B}$ averages $23 \mathrm{~cm}$ thick, and although the soil color and composition are unchanged from the overlying zone, there is a noticeable increase in cultural materials, and snail shells were especially noticeable in the profile. Soil zone $2 \mathrm{C}$ is identical to soil zone $2 \mathrm{~A}$. All of the subzones of soil zone 2 contained burned rock, bone fragments, chipped stone artifacts and debitage, mussel shell and snail shell fragments, and charcoal flecks.

A relatively thin burned rock midden averaging $40 \mathrm{~cm}$ thick (98.70-98.30 in elevation) lies between soil zones 2 and 3 . The burned rock midden contained tightly compacted fist-sized, angular burned limestone rocks, with little soil between the stones, although some areas did contain relatively fewer stones than the 


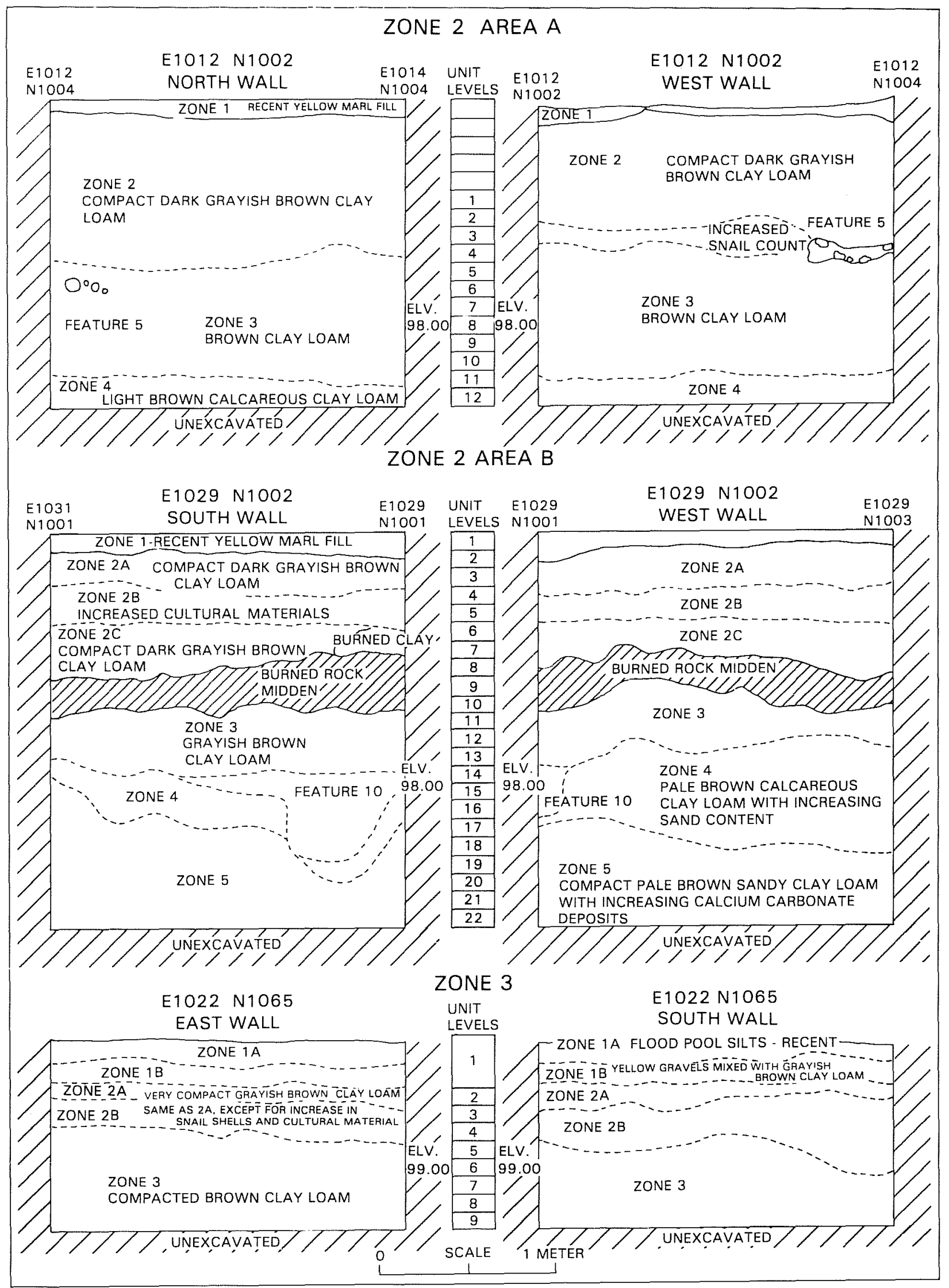

Figure 4. Soil Profiles from $41 \mathrm{BX} 1$. 
average density. Calcium carbonate deposits are common on materials recovered from this zone. The soil between the burned rocks is a dark grayish brown, silty clay loam. Archaeological materials from this area include lithics, bone fragments, mussel and snail shells, charcoal, and small baked clay nodules.

Soil zone 3 lies beneath the burned rock midden, and averages $50 \mathrm{~cm}$ thick (98.50-98.00 in elevation). It consists of a grayish brown clay loam slightly lighter in hue and lower in clay content than soil zones 1 and 2. Mineralized root fragments and an increase in charcoal and burned or baked clay nodules were common in this zone. Other associated materials include burned rocks, lithics, bone fragments, mussel shell fragments, and snail shells.

Soil zone 4, about $50 \mathrm{~cm}$ thick (98.10-97.60 in elevation), is characterized by increasingly compacted, pale brown, sandy silt loam with occasional calcium carbonate inclusions. In this zone, there is an abrupt decrease in cultural materials, which is limited to lithics, burned rocks, and snails.

Below soil zone 4 is the deepest recorded soil zone at the site. Soil zone 5 is a very compact, pale brown, sandy silt loam mottled with bluish gray calcium carbonate deposits. The soil zone averages about $60 \mathrm{~cm}$ thick, 97.90-97.20 in elevation. Cultural material was sparse within this soil zone.

\section{ARCHAEOLOGICAL ZONE 3}

Defined by Kelly (Kelly and Eaton 1979), Archaeological Zone 3 was identified as a horizontally separate component of $41 \mathrm{BX} 1$. This zone is located approximately $70 \mathrm{~m}$ north of Archaeological Zone 2 in Area B. Trenches 17 and 18 and Unit E1022 N1065 comprise this area. The area's major manifestation was first seen as an occupational midden located just below the present surface.

Soil zone 1 is subdivided into two parts. Soil zone $1 \mathrm{~A}$ is a grayish silty alluvium representing flood pool sediments. It is virtually sterile, except for a few recent historic artifacts. Soil zone 1B is a compacted dark grayish brown, silty clay loam mixed with occasional yellow gravels and historic and prehistoric artifacts. This soil layer was probably laid down during dam construction. The zone averages $25 \mathrm{~cm}$ thick (99.80-99.50 in elevation).

Soil zone 2 is the uppermost undisturbed soil zone, $99.50-99.00$ in elevation, and averaging $40 \mathrm{~cm}$ thick. The soil zone is divided into two subzones, $2 \mathrm{~A}$ and $2 \mathrm{~B}$, based on the amount of cultural materials observed in each. The soil in both subzones is a compacted grayish brown silty clay loam. At the contact between soil zone $1 \mathrm{~B}$ and $2 \mathrm{~A}$, the historic artifacts and yellow gravels cease, and intact prehistoric deposits become more common. Soil zone $2 \mathrm{~B}$ has the same soil composition and texture as soil zone $2 \mathrm{~A}$, however, there is a noticeable increase in cultural material. Materials common to both soil zones include burned rocks, bone fragments, lithics, mussel shell fragments, snail shells, and charcoal flecks.

Soil zone 3 is a compacted brown silty clay loam. The contact with soil zone $2 \mathrm{~B}$ is smooth and gradual, marked by a decrease in the clayey texture of the soil and a slight lightening of the hue. Excavations were ceased at $98.70(120 \mathrm{~cm}$ below the surface $)$.

\section{DISCUSSION}

All three areas investigated showed similarities within the soil profiles. Soil boundaries were weakly developed with smooth, gradual boundaries. Additionally, the soil zones, apparently representing natural soil horizons, are comparable as identified, zone to zone, so that the occurrence of each soil zone can be considered at this point a site-wide phenomenon. The significance of the soil profiles within each area, although not considered a cultural strata, can be useful in considering the chronological sequence at the site. The implications of the relationship of the soil zones to the cultural sequence at the site are discussed later in this report. 


\section{RADIOCARBON DATES}

Five wood charcoal samples collected during the course of the field work were submitted to The University of Texas Radiocarbon Laboratory, Austin, for assay, and the results are presented in Table 2. Additionally, a previously unpublished date for the site, from a sample collected and submitted in conjunction with the UTSA Summer Field School operations, is presented. For comparative purposes, Assad's (1979) radiocarbon assay is also included. Figure 5 presents the samples related to the cultural chronological sequence for central Texas.

TABLE 2. 41 BX 1 RADIOCARBON DATES

\begin{tabular}{|c|c|c|c|c|}
\hline $\begin{array}{l}\text { Sample } \\
\text { Number }\end{array}$ & Location & B.P. Date & $\begin{array}{l}\text { MASCA } \\
\text { Calibration* }\end{array}$ & Cultural Associations \\
\hline $\mathrm{TX}-2927$ & $\begin{array}{l}\text { Zone 1, Trench } 5 \\
\text { ca. } 160 \mathrm{~cm} \text { deep }\end{array}$ & $3560 \pm 70$ & 1950-1920 в.С. & Travis-like, Nolan \\
\hline TX-3799 & $\begin{array}{l}\text { Zone } 2 \text {, Area B } \\
\text { UTSA Summer Field } \\
\text { School Profile }\end{array}$ & $4110 \pm 70$ & 2800-2540 в.C. & $\begin{array}{l}\text { Top of midden, } \\
\text { Early Corner Notched, } \\
\text { Travis }\end{array}$ \\
\hline TX-3989 & $\begin{array}{l}\text { Zone 2, Area A } \\
\text { E1012.05 N1002.30 } \\
\text { Elevation } 98.62\end{array}$ & $2200 \pm 70$ & 400-130 B.C. & $\begin{array}{l}\text { Pedernales, Tortugas, } \\
\text { Castroville, Ensor, Frio }\end{array}$ \\
\hline TX-3990 & $\begin{array}{l}\text { Zone 2, Area A } \\
\text { E1015.99 N1003.51 } \\
\text { Elevation } 98.18\end{array}$ & $3310 \pm 110$ & 1680-1460 в.С. & $\begin{array}{l}\text { Burned rock scatter } \\
\text { intruded by Burial } 10\end{array}$ \\
\hline TX-3991 & $\begin{array}{l}\text { Zone 2, Area B } \\
\text { E1029.67 N1001.90 } \\
\text { Elevation } 98.19-98.11\end{array}$ & $4380 \pm 100$ & 3150-2880 в.C. & $\begin{array}{l}\text { Feature } 10, \text { bottom } \\
\text { of soil zone } 3\end{array}$ \\
\hline TX-3992 & $\begin{array}{l}\text { Zone } 3 \\
\text { E1022 N1065 } \\
\text { Elevation 98.90-98.80 }\end{array}$ & $3710 \pm 250$ & 2460-1690 B.C. & Kinney \\
\hline TX-3993 & $\begin{array}{l}\text { Zone 2, Area A } \\
\text { E1012 N1002 } \\
\text { Elevation } 98.78-98.67\end{array}$ & $1920 \pm 160$ & 100 B.C.-A.D. 260 & $\begin{array}{l}\text { Feature 2, Burials } 8 \\
\text { and } 9\end{array}$ \\
\hline
\end{tabular}

*Ralph, Michael, and Han (1973)

SAMPLE TX-2927: $3560 \pm 70$ B.P.

The radiocarbon date of a charcoal sample from Archaeological Zone 1 has been previously discussed by Assad (1979). Nolan and Travis-like dart point types were associated with this sample. Assad (1979) suggested that the radiocarbon date was late compared to what was generally expected for either Travis or Nolan types of the Clear Fork phase.

SAMPLE TX-3799: $4110 \pm 70$ B.P.

The charcoal sample was collected by the UTSA Summer Field School in 1979, just after Zone 2 in Area B was exposed by borrow operations. The sample was taken from the upper levels of the burned rock midden feature which at that time was reported to be associated with Pedernales dart point types. Later excavations into the midden recovered an Early Corner Notched and a Travis dart point. Although the date is earlier 


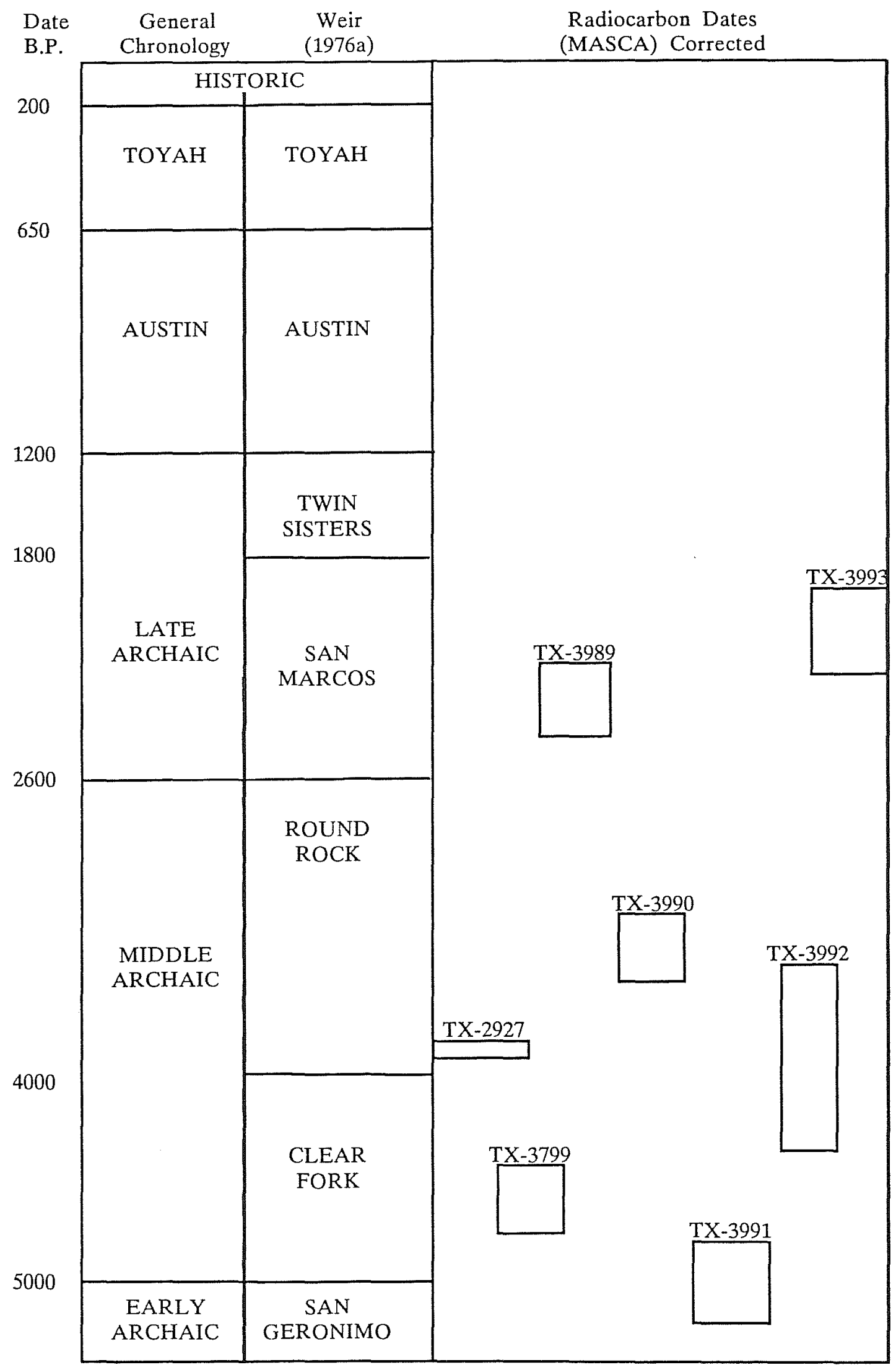

Figure 5. Radiocarbon Dates from 41 BX 1 Compared to Chronological Sequence for Central Texas. 
than first expected, it is more in line with expected dates for Travis point types and would suggest that the midden is an early Middle Archaic (Clear Fork phase) feature.

SAMPLE TX-3989: $2200 \pm 70$ B.P.

The charcoal sample was taken from Unit E1012 N1002, Level 2 at an elevation of 98.62. It was intended as a comparison sample for TX-3993, which was directly associated with Feature 2, and to aid in providing an absolute date for the burial component. Two projectile points (a Pedernales and a Tortugas)were associated with Level 2 of Unit E1012 N1002; however, Late Archaic point types (Castroville, Ensor, and Frio) were recovered from levels at the same elevation in adjacent units. The dates recorded for samples TX-3989 and TX-3993 would suggest an upper range of between 400 B.C. and A.D. 260 for the burial features at the site.

SAMPLE TX-3990: $3310 \pm 110$ B.P.

The charcoal sample was removed from a burned rock scatter that had been intruded upon by Burial 10 in Unit E1014 N1002, Level 7 at an elevation of 98.18. The sample was intended to provide a lower age range for the burial component, as Burial 10 was the second deepest burial at the site, and at the same time provide a general indication of age for a number of burned rock features within Zone 2 of Area A. Features 1, 3, 7, 8 , and 9 (burned rock features within Zone 2 of Area A) all had maximum recorded depths of between 98.25 and 98.13, corresponding to the burned rock scatter from which this sample was recorded. The date assigned to sample TX-3990 suggests Middle Archaic (Round Rock phase) activities occurred in Area A prior to its use as a cemetery.

\section{SAMPLE TX-3991: $4380 \pm 100$ B.P.}

The charcoal sample was recovered from Unit E1029 N1001, Level 13 at an elevation between 98.19 and 98.11. The sample was taken from the bottom of soil zone 3 and was associated with, but not from the burned clay anomaly, Feature 10. This sample provided the earliest date recorded for the site. No artifacts were associated with the radiocarbon sample, however, Early Corner Notched, Travis, and Form 6 (Travis-like) projectile points were recorded for the lower levels of the burned rock midden, about $30 \mathrm{~cm}$ above the sample. The assay, taken in conjunction with TX-3799 from the top of the burned rock midden, brackets use of the midden to a time between 3150 B.C. and 2540 B.C. during the early Middle Archaic Clear Fork phase.

\section{SAMPLE TX-3992: $3710 \pm 250$ B.P.}

The sample was submitted in order to date the lowest occurrence of cultural materials in the Zone 3 excavations. The sample was not collected from any single location within Level 8 of Unit E1022 N1065, but is rather a unit-level sample, collected from the unit as it was excavated. Associated with this sample were a Kinney dart point type of the Middle Archaic period and a relatively dramatic increase in the debitage count. The radiocarbon assay suggests a Middle Archaic (Round Rock phase to Clear Fork phase) occupation at this level.

\section{SAMPLE TX-3993: $1920 \pm 160$ B.P.}

The charcoal sample was taken from within the burned rock cluster of Feature 2. Feature 2 was directly associated with two infant burials (Burials 8 and 9), which were among the highest in elevation recorded at the site. Because of the elevation of the feature and the two burials, it was felt that the radiocarbon date should provide a minimum date for the use of the cemetery. The date lies within the Late Archaic period (San Marcos phase), and the accuracy of the date is supported by sample TX-3989. 


\section{BURIAL DESCRIPTIONS}

Thirteen burial features were recorded at $41 \mathrm{BX} 1$ (Fig. 6). They are identified in this report as Burials 1 through 11, Burial 5A, and the 1979 UTSA Summer Field School Burial (F. S. Burial). All the burials are thought to have originally been simple, single primary inhumations of articulated corpses (Sprague 1968). Richard Shoup provides an analysis of the skeletal remains in Appendix II, including sex and age determinates for each of the burials, stature reconstructions, and metric analysis.

Descriptive terminology and recording methods were directly adapted from work by Sprague (1968) and Ubelaker (1978). Since field forms utilizing the same terminologies had been prepared by Grant Hall (1981) for use at the Ernest Witte site (41 AU 36) and by Barbara Butler for North Texas State University, their forms were used with slight modifications for recording at $41 \mathrm{BX} 1$.

Only Burials $6,7,8,9$, and 10 could be considered undisturbed by recent heavy machinery operations within the site. "Minimal" damage (obvious crushing, some bone displacement, or loss of small amounts of skeletal material) occurred in Burials 2, 3, 4, 5, and 5A. The heaviest damage occurred to Burials 1, 11, and the F.S. Burial. In the case of the F. S. Burial, basically only the inferior half (pelvis and below) of the skeleton was represented. For Burials 1 and 11, only portions of the skull and a very few other bones remained.

Four of the burials are represented by complete or nearly complete articulated skeletal remains (Burials 2 , 5,8 , and 10). Natural disturbances account for the incomplete remains of Burials 6,7 , and 9. Burial 5A is the only disarticulated mass of bones assigned a burial number. Indications are that Burial 5A was a simple primary inhumation later disturbed and subsequently reinterred as a disarticulated mass with Burial 5. Including Burial 5A, which represents a second individual within the grave of Burial 5, three other burials (Burials 2,3, and 6) had at least a single human bone, representing some other individual. However, in no instance was it felt that the elements represented could warrant increasing the individual count within the burial or for the cemetery.

Burials 6 and 7 probably represent a single individual. This opinion is based on the elements represented within each burial and the proximity of the two burials. Burial 6 contained cranial and rib fragments of an infant (as did the surrounding unit levels for that burial), while Burial 7 contained articulated portions of an infant skeleton representing bones from the pelvis down. It is strongly suspected that Burial 6 is the disturbed remains displaced from their proper anatomical position within Burial 7.

Where the data were available, all burials were placed on either the right (four) or left (six) side. Head rotation was characterized as forward (no head rotation). Arm positions involved a variety of placements: $\operatorname{arm}(\mathrm{s})$ extended along the body, hand(s) to face, $\operatorname{arm}(\mathrm{s})$ crossed on chest, and lower arm(s) extended away from the body. The position of the legs tended to be flexed (only Burial 10 was recorded as semiflexed) with the lower part of the legs flexed at a smaller (tighter) angle than the upper part of the legs (classification for the burials is based on the flexure of the upper part of the legs for convenience in discussion). Although complete assessment of body positioning was not possible in all cases, the information available was used to make assumptions or reasonable estimates of the body positions. Such assumptions are given as ranges, or are noted in the text as estimates.

Orientation was generally easterly. Where specific orientation was observable, four burials were oriented $61^{\circ}-82^{\circ}$ (an east-northeast orientation), and one was to the east-southeast $\left(105^{\circ}\right)$. Estimates for the other burials fell to the east of magnetic north or south. Burial 8, an infant, is the only exception to the generally easterly tending burials. It was oriented to the west-northwest $\left(312^{\circ}\right)$.

Age at time of death ranged from infant to mature adult. Age categories are the following: infant (0-1 year), child (2-3 years), young adult (16-18 years), and mature adult (19-40 years). Age estimates assigned to burial features are four infants, one child, two young adults, and six mature adults.

Infants and the child were not assigned sex estimation (Bass 1971). Of the adults, four are estimated to be males, two estimated as females, and two could not be assessed. 


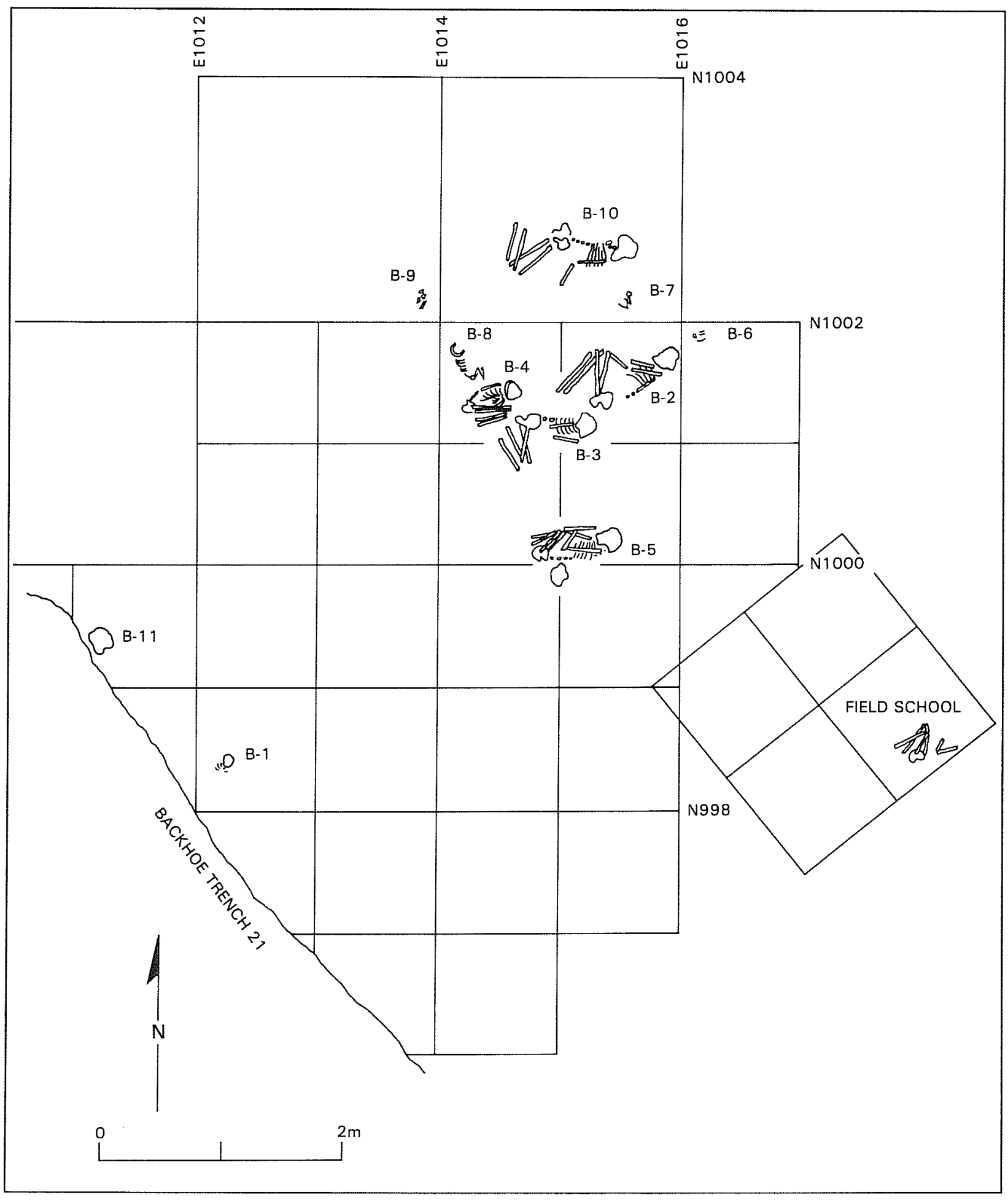

Figure 6. Burial Plan of Zone 2 in Area $A$ at $41 B X 1$. Burial $5 \mathrm{~A}$ is not shown, see text for location. 
Included as grave goods within 10 of the burials were unmodified antler beams and racks, freshwater mussel shell, marine shell, worked bone, worked and unmodified chert, and ground stone.

Antler was the most common grave inclusion, occurring in seven burial features. A count of antler bases revealed that between two (Burial 6) and 21 (Burial 2) specimens were placed with individual burials. Antler was associated with both infants and adults and generally found placed directly above the body and over the chest area and sometimes in the leg areas. Antler (except in the case of infants, who were completely covered) never covered the head.

Mussel shell was the next most common grave inclusion, occurring as small rectangular to trapezoidal-shaped pendants in six of the burials. Pendants were associated with the neck, hands, and feet. In one instance an unmodified mussel shell was associated with Burial 2.

Marine shell was with three burials, generally in the neck or chest area. Lightning whelk (Busycon contrarium) body whorl pendants and possibly horse conch (Pleuroploca gigantea) columella dangles were the materials used for the shell ornaments.

Other grave inclusions include five bone beads associated with two burials; six chert cobbles associated with three burials; and a bone awl, a ground stone slab, and two biface fragments associated with a single burial. Ocher was with eight of the 13 burials, generally occurring as stains or very small pebbles.

The burials were within a 8- x 5-m block of units, with a strong tendency for the burials to cluster in the northeast corner of that block. There was some question as to the individuality of Burials 2,3 , and 4 , but examination of the elevations, proximity, and positioning of the skeletons suggests that no multiple interments are represented at the site. It appears that if more burials are present at the site, they must lie due east of these.

\section{FIELD SCHOOL BURIAL}

Horizontal location: Pelvis E1017.95 N998.45

Vertical location: Distal end of left fibula 98.62 , right femur 98.64 , pelvis 98.56

Age and sex estimates: Mature adult

General body placement: The F. S. Burial was represented by the legs, pelvis, portions of the lower arms, and the distal end of the right humerus (Fig. 7,a); these skeletal remains were crushed and highly fragmented by heavy machinery. The body was apparently placed on its right side in a semi to tightly flexed position (exact determination is impossible due to the missing upper torso and skull). Both lower legs were flexed at $20^{\circ}$. Upper legs are estimated to have been flexed $20^{\circ}-140^{\circ}$ in relationship to the body axis based on the available data (position of the pelvis and location of lower arms). The left lower arm rested with the distal end of the radius, ulna, and the carpals roughly parallel to the femur and extended away from the body. The right lower arm and the distal end of the right humerus were in a position suggesting that the lower arm was extended to between the legs at the pelvis. Body orientation is estimated to be between $60^{\circ}$ and $190^{\circ}$ east of north (between east-northeast and south-southwest with the most likely position between those two points, i.e., to the southeast).

Grave inclusions: No grave goods were recorded with the burial. A Pedernales point, however, was recovered from the southwest quadrant of Test Pit 1 . The burial was excavated from the southeast quadrant of that $2-\mathrm{m}^{2}$ unit. 


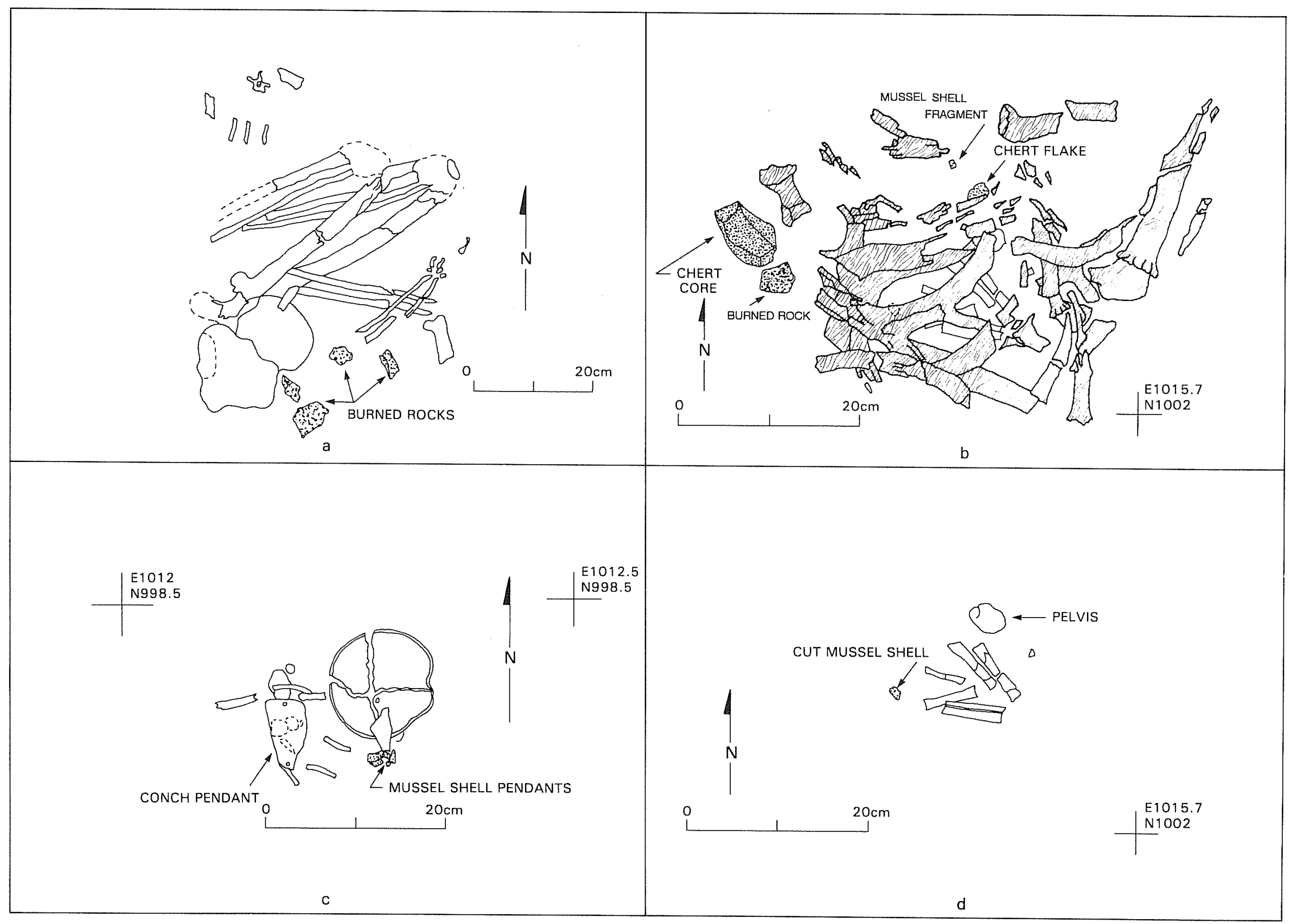




\section{BURIAL 1}

Horizontal location: Center of skull fragments at E1012.29 N998.41

Vertical location: Between 98.45 and 98.40

Age and sex estimates: Child between 1-1/2 to 2-1/2 years of age

General body placement: Burial 1 was disturbed by Trench 22 and borrow operations in 1979. In fact, it came quite close to being completely obliterated. The remains do, however, indicate an easterly orientation and the presence of grave inclusions with a young child.

Burial 1 was represented by partial upper torso and skull remnants of a recently disturbed and disarticulated skeleton (Fig. 7,c). Skeletal remains include portions of the right side of the skull, sections of a diaphysis of a humerus, fragmented rib bones, vertebrae fragments, a few teeth, and portions of the mandible. Although most of the bones were missing, those that remain suggest that the individual was placed with the skull on the right side, and the head was the most easterly portion of the body, indicating orientation to be east of either due north or south.

Grave inclusions: Three kinds of grave goods were included with Burial 1: a punctated conch pendant (Specimen 2) in the chest area, nine cut mussel shell pendants grouped closely together and adjacent to the skull (possibly indicating a necklace), and traces of red ocher around the bone fragments.

\section{BURIAL 2}

Horizontal location: Skull E1015.88 N1001.60, pelvis E1015.50 N1001.37

Vertical location: The highest elevations for deer antler associated with Burial 2 are 98.47 and 98.46. The bottom elevations of the skeletal remains are: skull 98.24, right pelvis 98.20 , and right calcaneas 98.32 .

Age and sex estimates: Mature male adult between 17 and 25 years of age

General body placement: Burial 2 (Fig. 8) was a flexed burial lying on its right side, oriented $61^{\circ}$ east of north. The skull was also resting on its right side facing the west-northwest. Flexure for the legs given in degrees is as follows: upper left $70^{\circ}$, upper right $50^{\circ}$, lower left $40^{\circ}$, lower right $25^{\circ}$. The left arm was extended and between the knees. The right arm was crossed over the chest, the hand resting on the top of the left arm just above the left elbow. There was no recorded construction disturbance of the skeleton, although some antler above the body may have been removed. Naturally occurring disturbance, assumed to be rodent, root, and soil-related modifications, included a high degree of postmortem bone fractures, slight disarticulation of the feet and hands, some displacement of the radius and ulna, and missing lower lumbar vertebrae and ribs.

Grave inclusions: Two chert cobbles, four incised columella dangles, a punctated conch body whorl pendant, unmodified mussel shell, cut mussel shell pendant fragments, a bone awl, four bone beads, one biface, one distal fragment of a biface, a core, a ground stone slab, 21 deer antler bases with numerous additional fragments of the beams and tines, and red ocher stains were within the grave.

Only one of the deer antler bases is recognized as shed; the others are thought to be broken off near or in addition to the deer skull. Eleven of the bases were identified as white-tailed deer (Caras 1967). None of the bases could be clearly matched with a rack, as was the case with the other burials. It is assumed that a minimum of 11 deer are represented, based on the occurrence of the identifiable parts. The majority of the antler tended to cover the torso, but the order of placement was not analyzed. 


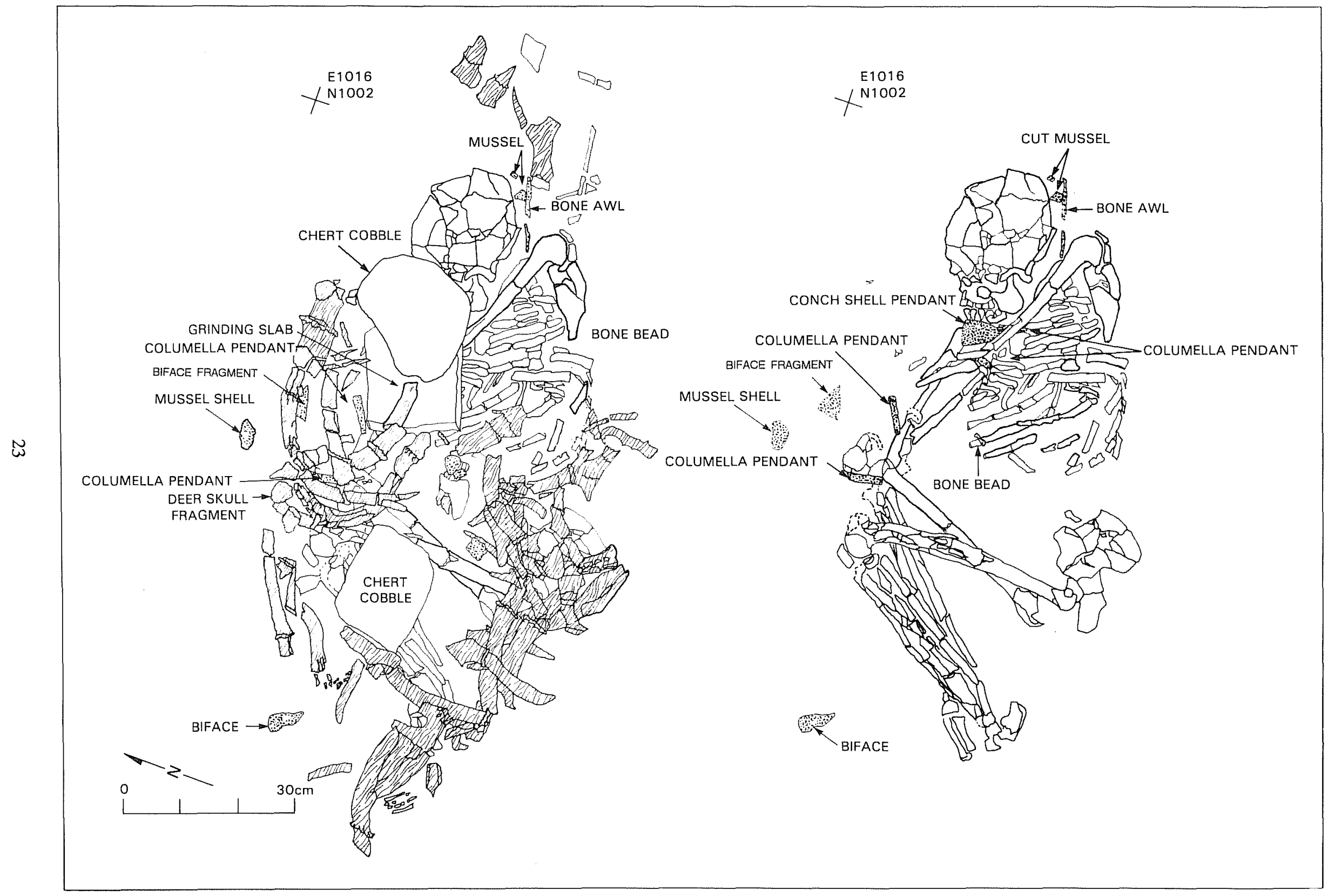


The context of some of the inclusions warrants comment. A conch pendant (Specimen 3) was located just below the mandible, and on either side of the pendant were incised columella dangle specimens aligned so that it appeared that all three specimens would have been suspended on the same string or cord. The remaining two incised columella dangles were located away from the body and may have been displaced. The pendant is thought to be lightning whelk (Busycon contrarium), and the dangles may be horse conch (Pleuroploca gigantea).

The chert cobbles and the ground stone appear to be in their original context. The bone awl also appears to be in its probable original position. The base of the awl was located beneath the cervical vertebrae, near the base of the skull and extended so that the pointed end was behind the skull. The awl may have been worn in the hair. The remaining inclusions were generally located to the north side of the burial, except for the cut mussel shell pendant fragments and the core. The pendant fragments were near the bone awl, south of the skull, and the core was slightly farther east and south of the skull. A complete biface was located approximately $20 \mathrm{~m}$ due west of the approximate midpoint of the lower legs. It is unknown if this is an intentional offering or if it is part of the fill. Of the four bone beads, one was found near the stomach area, and another was recovered from near the legs. The unmodified mussel shell, the distal end of a biface, and two of the incised columella dangles came from the area just north of the chest region and were scattered among antler beam fragments and sections.

\section{BURIAL 3}

Horizontal location: Skull E1015.18 N1001.17, pelvis E1014.67 N1001.12

Vertical location: Antler was recorded from 98.42 to 98.20 . Skeletal elevations extended from 98.28 to 98.18. Specific elevations of the skeletal remains are: skull 98.18, pelvis 98.22, feet 98.29.

Age and sex estimates: Mature female adult, 17 to 25 years of age

General body placement: Burial 3 was flexed, lying on its left side (Fig. 9), oriented $82^{\circ}$ east of north. The skull rested on the left side, facing the southeast. Flexure for the legs given in degrees is as follows: upper right $85^{\circ}$, upper left $65^{\circ}$, lower right $30^{\circ}$, lower left $20^{\circ}$. Note that the lower part of the legs is more flexed than the upper part of the legs. Arms were apparently flexed towards the face. There was some recorded construction disturbance, consisting of crushing and removal of a very small portion of the right knee area (the patella, distal end of the femur, and the proximal ends of the tibia and fibula were crushed). Some naturally occurring disarticulation had taken place; it was confined mainly to the arms, hands, and feet. Portions of the upper arms were disturbed and fragmented. Portions of a maxilla and cervical vertebrae near the knees of this burial and the presence of a radius of a second individual indicate there may have been some later disturbance of an earlier interment, but evidence was too slight to assign a burial number (or to identify as an individual).

Grave inclusions: Red ocher stains and deer antler and skull fragments were the only grave goods with Burial 3. Ocher was most visible near the back of the skull, but traces were present throughout the grave fill. Eleven antler bases were in the grave fill, and long sections of antler beams covered the body from the legs to the chest area. Four of the antler bases were from white-tailed deer (Caras 1967). Although it was apparent that at least complete half racks had been placed in the burial, the provenience of these offerings did not indicate that sets (pairs) of racks had been included in the burial. A minimum number of six and a maximum of 11 deer are represented in the burial.

\section{BURIAL 4}

Horizontal location: Skull E1014.63 N1001.39, pelvis E1014.29 N1001.33 


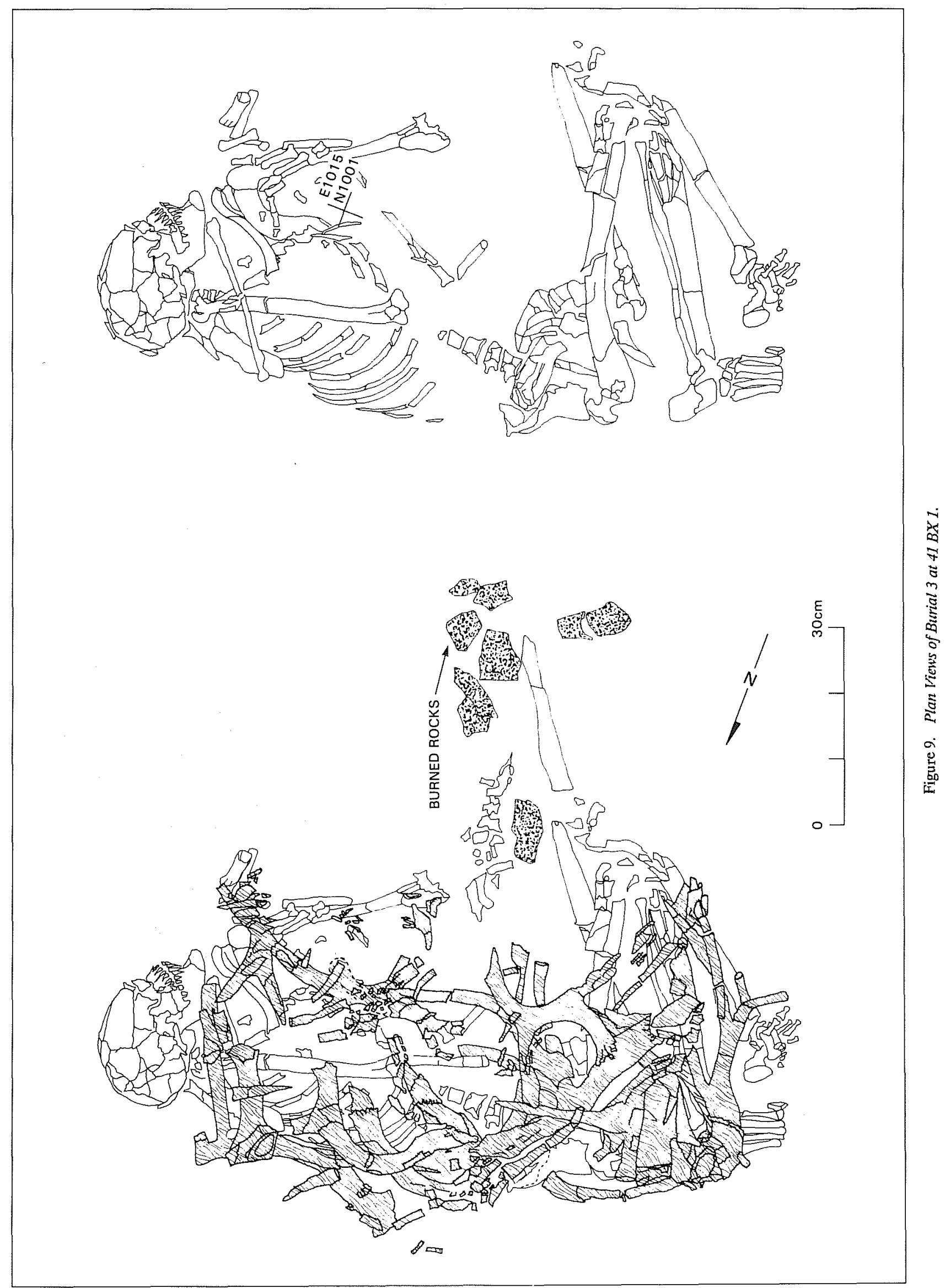


Vertical location: Highest point of the burial was the skull (which had already been partially removed) at 98.54. The lowest elevation was at the bottom of the pelvis, 98.27.

Age and sex estimates: Young female adult, 14-18 years of age

General body placement: Burial 4 was flexed and on its left side (Fig. 10,b). There was no head rotation. The body was in an unusual position; it seemed to be in a slumped sitting position leaning off to its left side. The head was $27 \mathrm{~cm}$ above the pelvis. Flexure for the legs given in degrees is as follows: upper right $35^{\circ}$, upper left $25^{\circ}$, lower right $20^{\circ}$, lower left $10^{\circ}$. Arms were extended along the sides. Disturbance by construction was limited to displacement and damage to the skull. Orientation was to the east-northeast, $68^{\circ}$ east of north. Other postinterment disturbance included damage to the distal ends of the femora, tibiae, and fibulae. The patellae were missing (both would have been in very close proximity to Burial 3 ), and may indicate postinterment disturbance of Burial 4 took place during grave preparations for Burial 3. Some natural disarticulation and postmortem fracturing of the bones were noted. Disarticulation was mainly limited to the extremities.

Grave inclusions: Ocher was found beneath the right scapula, and traces of the substance were present in the fill around the body.

\section{BURIAL 5}

Horizontal location: Skull E1015.35 N1000.19, pelvis N1014.87 N999.98

Vertical location: Skull 97.91, pelvis 97.94

Age and sex estimates: Mature male adult, 25-35 years of age

General body placement: Burial 5 was flexed and on its right side (Fig. 11). Flexure for the legs given in degrees is as follows: upper right $20^{\circ}$, upper left $15^{\circ}$, lower right $5^{\circ}$, lower left $25^{\circ}$. The left leg was crossed under the right leg. This burial approaches a tightly flexed position (Ubelaker 1978). The right arm was flexed towards the face. The left arm was flexed across the chest, and the hand rested on the approximate center of the right humerus shaft, overlain by the right radius and ulna (as if the left hand was holding or resting on the biceps of the tightly flexed right arm). Skeletal remains were complete and articulated except for some missing phalanges from the hands and feet. Construction disturbance was limited to the uppermost levels of the recorded burial and consisted of crushing and possibly some removal of the deer antler. Postmortem fractures were common.

Grave inclusions: Six deer antler bases were overlying the burial. Four of these bases represented two in situ deer racks attached to the frontal bones of the deer skull. These two racks were placed with the bases near the pelvis area, the racks extending over the chest. The other two antler bases were found over the chest area along with deer skull fragments, but their original context could not be determined as it is believed that postinterment displacement (construction or natural) had moved the racks from their original position. None of the antler is shed, and it is assumed three racks were placed within the burial pit, although a maximum of four deer could be represented by the bases.

Two cut mussel shell pendants were recovered, but neither was in a context suggestive of where the shell was assumed to be worn. A small amount of ocher was found above the pelvis region, and traces were present in the fill. Unidentified fish bones were recovered directly above and on the sacrum. Because of their location and the relatively undisturbed nature of the articulated skeleton, it is believed that these bones may represent fecal contents, and hence not a grave offering. The skeletal remains of Burial $5 \mathrm{~A}$, which may be considered an inclusion, are discussed separately. 


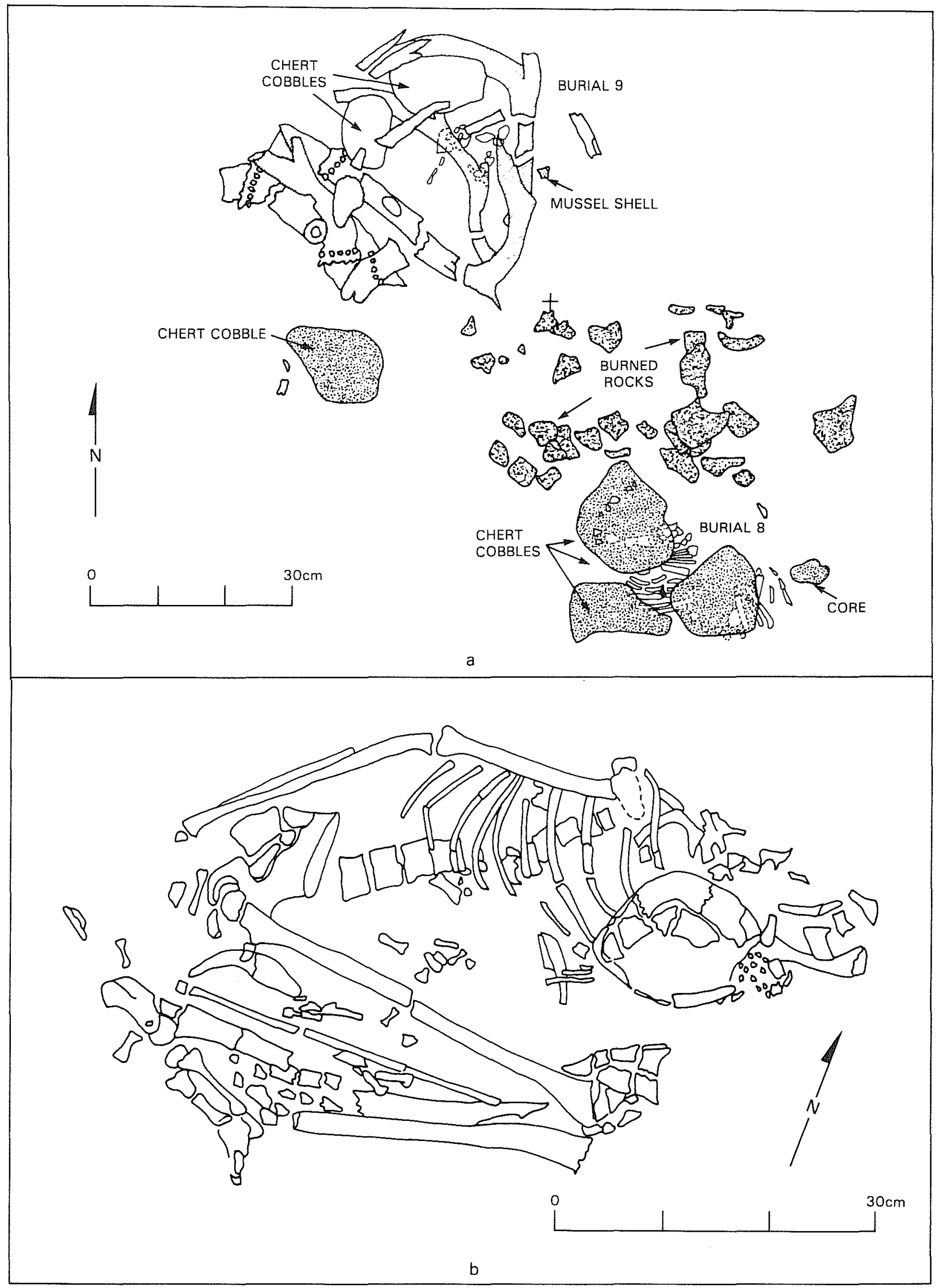

Figure 10. Plan View of Feature 2 Overlying Burials 8 and 9, and Plan View of Burial 4 at 41 BX 1. a, plan view of Feature 2 overlying Burials 8 and $9 ; \mathbf{b}$, plan view of Burial 4 . 


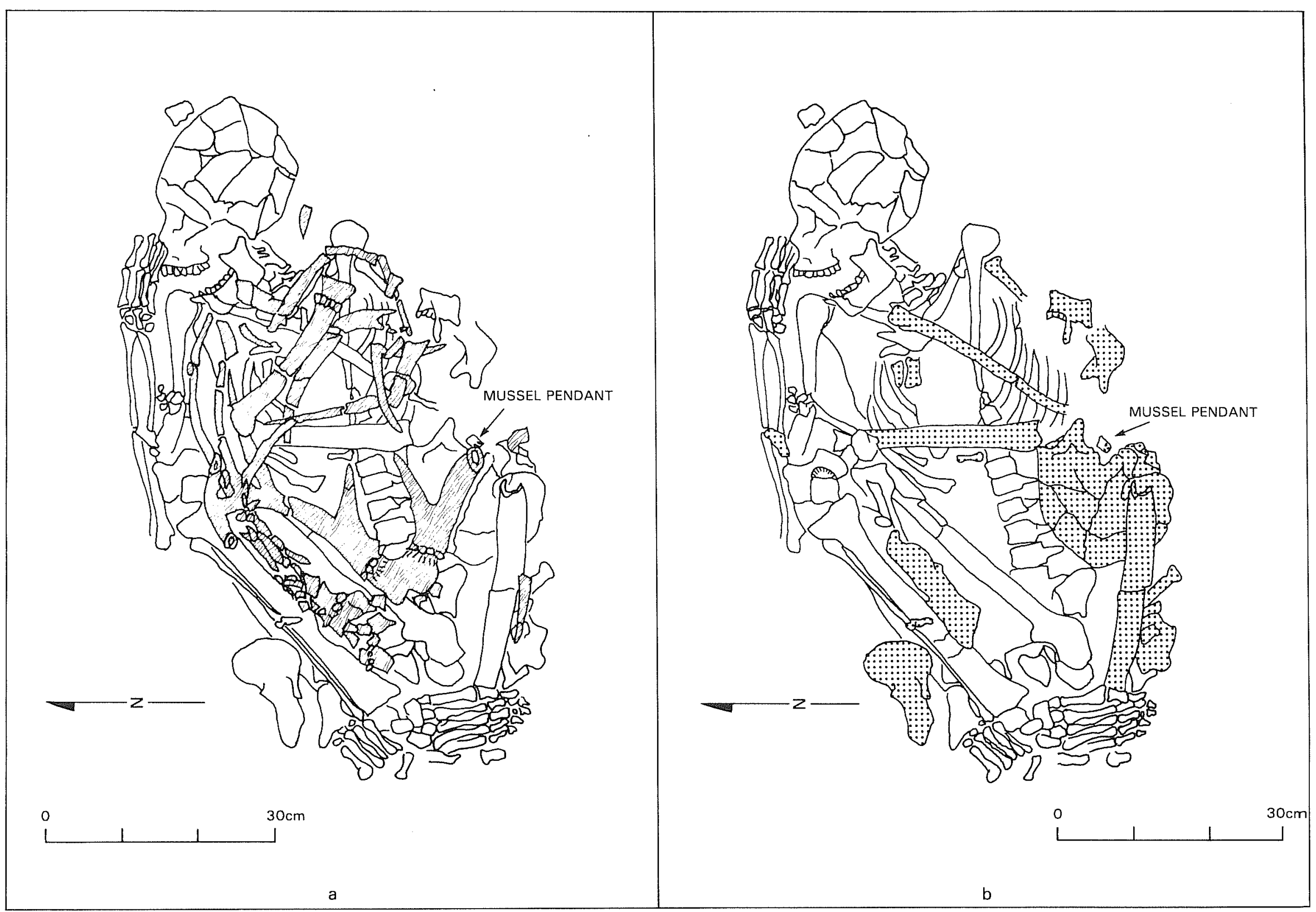

Figure 11. Plan Views of Burials 5 and $5 A$ at $41 B X 1$. a, Burial 5 with antler overlying the skeleton; b, plan view of Burials 5 and $5 \mathrm{~A}$. 
BURIAL 5A

Horizontal location: Skull E1015 N999.90, pelvis ca. E1014.84 N1000.15

Vertical location: Skull 98.03, other bone all overlying Burial 5 and below 98.20

Age and sex estimates: Adult male, 17-25 years of age

General body placement: Burial 5A was a disarticulated, secondary interment of what was probably an earlier, simple primary inhumation of a single individual. All of the bones associated with Burial 5A were above the articulated skeleton of Burial 5 (Fig. 11,b). Identified bones of Burial 5A include the skull (all of the maxilla missing), mandible, right scapula, both radii, right ulna, portions of the pelvis, the left femur, both tibiae, left fibula fragments, the navicular, and a tarsal. The bones were generally scattered above the chest area and to the left side of Burial 5. Portions of the burial may have been removed by construction activity, as indicated by recent breaks on the tibia fragment overlying the skull of Burial 5A.

The number of postcranial remains and the absence of any evidence around Burial 5 (the primary interment) of a disturbed burial indicates that there is some possibility this could represent a secondary burial intentionally interred with Burial 5. In view of the rarity, however, of secondary burials associated with primary interments (see Hester 1969), it is believed that the disarticulated bones represent an earlier simple primary inhumation that was completely disturbed by the placement of Burial 5.

Grave inclusions: Although inclusions for Burials 5 and $5 \mathrm{~A}$ may be mixed, it seems unlikely that the antler and ocher associated with Burial 5 should be associated with Burial 5A; but the cut mussel shell, found in no particular context within the grave fill, is less certainly assigned to Burial 5 . The only artifact that is directly associated with Burial 5A is a small dart point (Miscellaneous Form 4) found within the skull. The point was located in the approximate center of the braincase. Analysis by Richard Shoup (see Appendix II) was inconclusive as to the entry point of the projectile. The point is assumed to represent the cause of death.

\section{BURIAL 6}

Horizontal location: E1016.10 N1001.86 (approximate center of rib fragments)

Vertical location: $\quad 98.42-98.21$

Age and sex estimates: Infant, newborn to six months of age

General body placement: Burial 6 was initially identified by rib fragments in their proper anatomical order, of an infant, appearing within a small cluster of highly fragmented deer antler sections. Unidentifiable long bone and skull fragments were also encountered within the fill. Laboratory analysis points to the strong possibility that Burial 6 is actually portions of the upper torso of Burial 7. Infant remains were found in several levels beginning at 98.60 within Units E1015 N1001 and E1016 N100.

Grave inclusions: One cut mussel shell pendant fragment, two deer antler base sections, numerous small fragments of antler beams and tines, and a trace of red ocher were removed from the fill. The antler appeared thoroughly mixed, and one base was from a white-tailed deer.

\section{BURIAL 7}

Horizontal location: Skull missing, pclvis E1015.53 N1002.23

Vertical location: $98.64-98.60$ 
Age and sex estimates: Infant, newborn to six months of age

General body placement: Burial 7 was represented only by the fragmentary remains of the pelvis and leg bones (Fig. 7,b,d). The available information from plan maps and photographs suggests that Burial 7 was semiflexed to tightly flexed, lying on its left side, and oriented in a northerly to easterly direction. Based on the relationship of the upper legs to the pelvis fragments, flexure for the upper legs can reasonably be estimated to be between $0^{\circ}$ and $140^{\circ}$ in relationship to the probable axis of the body. This would mean that the burial had to have been in a very tight to semiflexed position. On the basis of this estimate, body orientation would fall between due north and $140^{\circ}$ east of north. It is very likely that the body was then oriented somewhere between these extremes and is given here as simply a northerly to easterly direction. Slightly disarticulated lower legs were estimated at approximately $40^{\circ}$ for the right lower leg and $60^{\circ}$ for the left lower leg. The portion of the body above the hips was missing entirely. However, infant remains from Units E1015 N1001 (98.50-98.40) and E1016 N1001 (98.50-98.40) and the whole of Burial 6 may, in fact, represent the scattered remains of this burial. Included in the inventory of bones from these units are the following: a deciduous molar of an approximately six month old infant, a metacarpal, and rib and long bone fragments of a small child. The close proximity of these units and Burial 6 to Burial 7 all suggest that these scattered remains are part of Burial 7.

Grave inclusions: Traces of red ocher, a mussel pendant fragment, and a less closely associated core were recorded with the burial. Feature 4, an antler concentration of bases and beams, representing at least three deer, was directly overlying the burial.

\section{BURIAL 8}

Horizontal location: Skull E1014.64 N1001.15, pelvis E1014.52 N1001.28

Vertical location: Skull at 98.57, distal end of right tibia and fibula at 98.64

Age and sex estimates: Infant, 8 to 10 months of age

General body placement: Burial 8 (Fig. 10,a) was almost complete, flexed, and was lying on its left side. Body orientation was to the northwest at $312^{\circ}$. There was no head rotation, and the skull faced the northeast. Arm flexure for both arms was uncertain as the radii and ulna were missing; the right and left humeri, however, extended across the chest away from the body, possibly indicating the lower arms were flexed at the elbow towards the face. Degree of leg flexure is: upper right $40^{\circ}$, upper left $60^{\circ}$, lower right $20^{\circ}$, lower left $30^{\circ}$. Although no rodent burrows or root disturbances were seen in the soil, some disturbance was indicated since a fragment of the maxilla or mandible was recorded approximately $15 \mathrm{~cm}$ east of the skull. Epiphyseal, vertebral, and pelvic remains were absent or present only as stains.

Grave inclusions: Three chert cobbles recorded as part of Feature 2 were placed directly above and covering the burial. Additionally, a single crustacean fragment was found resting directly on the top right side of the midchest area. Ocher stains were recorded in the pelvis area and beneath the body. A trace of mussel shell was noted beneath the skull.

\section{BURIAL 9}

Horizontal location: Approximate center of the bone cluster at E1013 N1002.25

Vertical location: $98.49-98.44$

Age and sex estimates: A newborn to two month old infant 
General body placement: Burial 9 remains were highly disturbed (Fig. 10,a), and no positioning or orientation information is available. A few cranial and postcranial remains were in a small cluster $21 \times 13 \mathrm{~cm}$. Rodent or root disturbance is assumed, but no soil changes could be noted around the bone.

Grave inclusions: An antler concentration of at least three white-tailed deer racks and a tested cobble recorded as part of Feature 2 were directly associated with this burial. Traces of ocher were also noted around the burial.

\section{BURIAL 10}

Horizontal location: Skull E1015.44 N1002.60, pelvis E1015.03 N1002.74

Vertical location: Range $98.22-98.07$, skull 98.09 , pelvis 98.16 , right foot (calcaneus) 98.21

Age and sex estimates: Young adult female, 16-19 years of age

General body placement: Burial 10 was a single primary inhumation, in a semiflexed position on its left side (Fig. 12). There was no head rotation, and the skull faced the south. Axis orientation was to the east-southeast at $105^{\circ}$ east of north. Both arms were in the same position, flexed at the elbow and extended away from the body. Flexure for the legs is: upper right $115^{\circ}$, upper left $120^{\circ}$, lower right $30^{\circ}$, lower left $35^{\circ}$. The phalanges of the right foot were beneath the left tibia and fibula, towards their distal ends. Rodent activity is suggested by a disturbed area near the left upper arm. Portions of the cervical vertebrae, the left scapula, and the left humerus were missing. There was some natural disarticulation and loss of hand bones. The skull was also probably disturbed by rodents, since portions were missing. Postmortem fracturing and some degree of bone deterioration were noted. There was no construction-related disturbance of this burial.

Grave inclusions: Nine antler racks (18 bases and associated deer skull fragments) were covering Burial 10. All are identified as from white-tailed deer. These were carefully placed atop one another with the base or cap of the skull placed towards or near the chest area. The racks completely covered the torso from the pelvis to the neck. Additionally, four body whorl conch shell pendants were associated with the burial. Three specimens were close to the neck, and one specimen was found beneath the sternum in such a manner as to suggest that the pendant was suspended from the neck and probably hung at mid to upper chest. A relatively large bone bead was found above the lower ribs. A cut mussel shell pendant necklace, of a minimum of 17 pendants, was found in excellent context just below the mandible. Three other cut mussel shell pendants were recorded in the fill near the hands, feet, and behind the skull.

BURIAL 11

Horizontal location: Center of skull at E1011.24 N999.40

Vertical location: Lowest elevation at 98.34

Age and sex estimates: Adult male, 25-40 years of age

General body placement: Only portions of the skull and a long bone were recorded for this burial. The skull was discovered eroding from the east wall of Backhoe Trench 21 . The maxilla and mandible were missing, but the remaining portions of the skull indicate that the skull laid on its right side, facing the south. Specific body orientation or articulation could not be documented.

Grave inclusions: None 


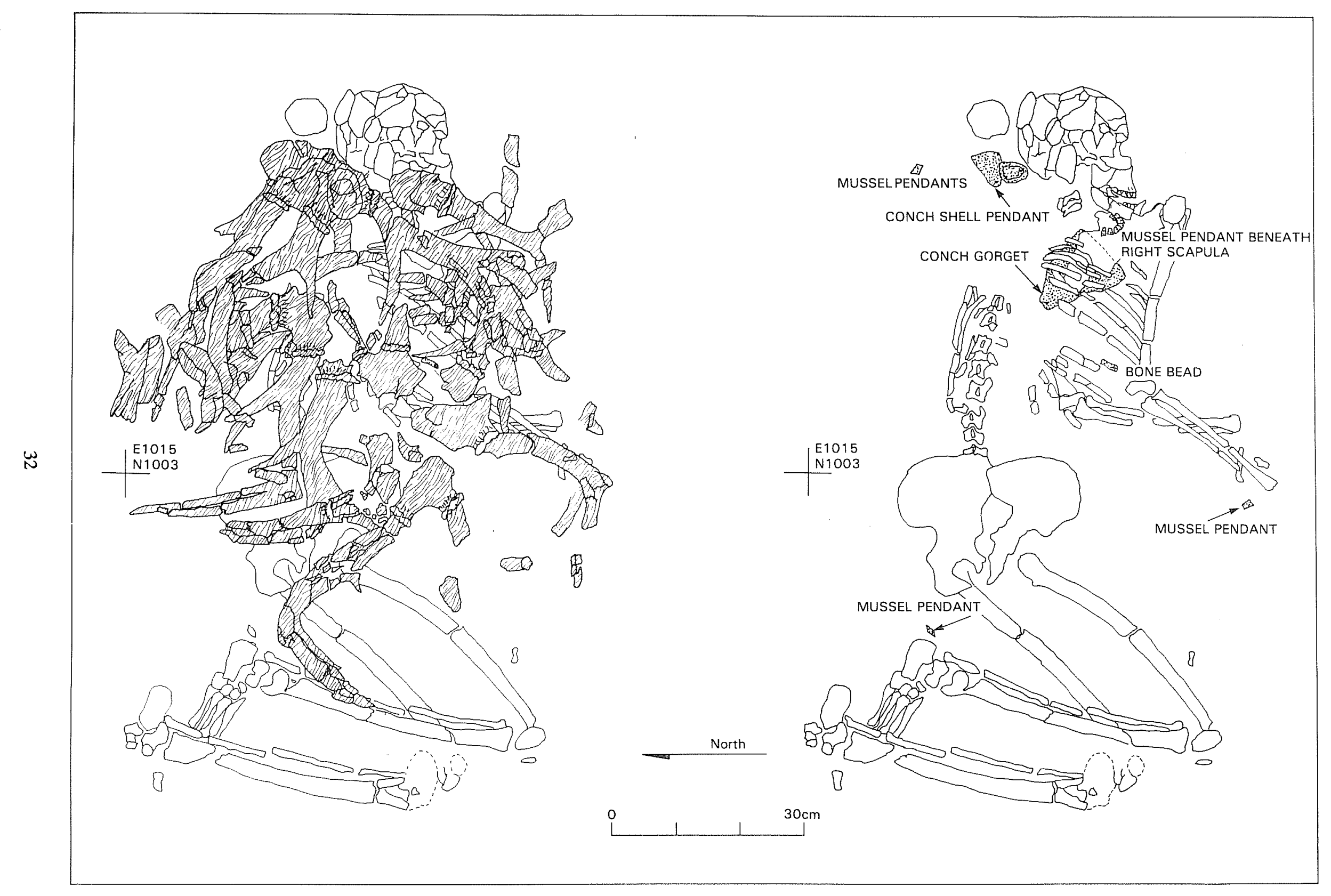

전

Figure 12. Plan Views of Burial 10 at 41 BX 1 . 
Feature Descriptions

\section{FEATURE DESCRIPTIONS}

Eleven features were recorded during the course of field work at $41 \mathrm{BX} 1$. Three basic types of features were recorded: offerings associated with burials, soil anomalies, and burned rock concentrations. The most common feature type was the burned rock feature (seven features), of which only one can be definitely described as a hearth (Feature 8). Soil anomalies are those features that were isolated and defined on the basis of soil matrix differentiation. Features 6 and 10 comprise the only two features of this type. Features associated with burials (Features 2 and 4) can be characterized as deer antler and/or chert offerings. Descriptive summaries for each of the features are presented next.

\section{FEATURE 1}

\section{Horizontal location: E1013.88 N998.65}

Vertical location: $98.22-98.17$

Description: Feature 1 (Fig. 13,a) was a small $(35 \times 25 \mathrm{~cm})$, tight cluster of reddish and bluish gray burned limestone rocks. The rocks were irregularly shaped, but were set on a single, flat layer. Fifteen burned rocks with a total weight of $1.4 \mathrm{~kg}$ were from within the feature. As the feature was only a few centimeters below heavy machinery blade cuts, it may be that portions of the feature had recently been removed. Some of the rocks had recently been crushed, and there was a disturbance consisting of small coal pebbles, a metal fragment, and yellowish clay immediately to the south of the feature. A single (rectangular) mussel shell pendant was the only closely associated prehistoric artifact. Feature matrix consisted of a dark brown clay loam undifferentiated from the surrounding soils.

The exact nature of the feature is unknown and is assumed to be an incomplete representation of a once larger burned rock concentration partially removed by a bulldozer.

\section{FEATURE 2}

\section{Horizontal location: E1014 N1002}

Vertical location: $98.78-98.47$. For the specific clusters within the feature, the following elevations were noted: the three chert cobbles were on a fairly level surface at about 98.64 , the antler concentration varied from 98.71 to 98.47 , and the burned rock concentration was recorded at 98.78-98.67.

Description: Feature 2 (Fig. 10,a) was a large area containing three distinct intrafeature clusters. The feature measured $90 \times 96 \mathrm{~cm}$. There was a cluster of small burned rocks, a cluster of deer antler and a single chert cobble, and a cluster of three chert cobbles. A clear relationship between the three intrafeature concentrations could not be determined; however, the three chert cobbles and the deer antler were placed directly overlying two infant burials, Burials 8 and 9, respectively. The burned rock concentration was located between the two burials.

The three chert cobbles over Burial 8 were each approximately $15 \times 15 \times 8 \mathrm{~cm}$ in size. Two of the cobbles had been "tested," one or two flakes had been knocked off the edges. All of the cobbles could be considered tough, poor quality chert. Their placement was such as to completely cover the infant's body and head.

The material overlying Burial 9 consisted of six antler bases; several long sections of antler beam in a relatively undisturbed context; and a single white, coarse-grained, tested chert cobble. The six antler bases were associated with deer skull fragments and paired in such a manner that it appeared as three racks had been placed as inclusions with the infant. The sequence of placement for the antler can be suggested as follows: the rack farthest to the east was placed in first, the rack farthest west was second, and the rack that sat just above and slightly east of the second rack was the last. 


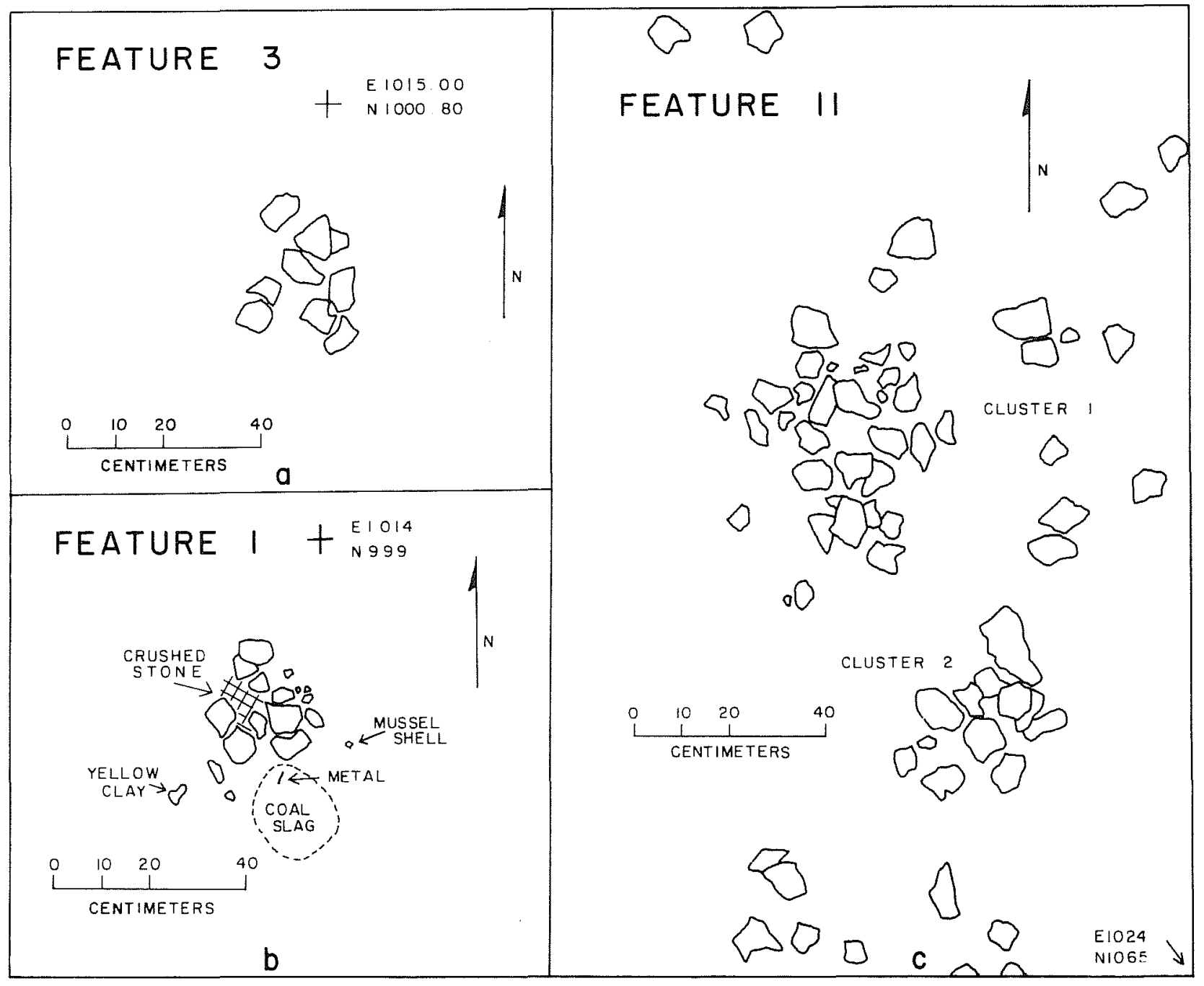

Figure 13. Features 1, 3 and 11 at $+1 B X 1$. a, Feature 3; b, Feature 1; c, Feature 11. 
A concentration of small burned rocks set between the two clusters consisted of approximately 32 small dark bluish gray crystalline (or cherty limestone) rocks that weighed a total of $0.7 \mathrm{~kg}$. Average size of the rocks ranged from 2 to $8 \mathrm{~cm}$. Wood charcoal from among the various rocks was collected and combined for a radiocarbon date (TX-3993). A soil sample fine screened from this cluster produced numerous fish bone.

In addition to the three clusters of materials discussed, burned and unburned bone, a core, a fragment of a mussel shell pendant, traces of red ocher, and an isolated chert cobble (presumably displaced from the antler concentration) were recorded. Soil matrix from the feature was identical to the surrounding soil, a compact brown silty clay loam, except within a few areas among the deer antler, where the soil was slightly more clayey.

\section{FEATURE 3}

Horizontal location: E1012.98 N1000.44

Vertical location: $98.26-98.20$

Description: Feature 3 (Fig. 13,b) was a small irregularly shaped cluster of burned rocks approximately $32 \times 35 \mathrm{~cm}$ in size. The feature was in the area between the feet of Burial 5 and the knees of Burial 3, at the same approximate level as the two burials. A total of nine burned rocks, ranging in size from 2 to $8 \mathrm{~cm}$, was recorded for the feature with a total weight of $1.9 \mathrm{~kg}$. A concentration of snail shells (mostly Rabdotus $\mathrm{sp}$.) was noted on the southeastern edge of the feature. Soil matrix within the feature consisted of a brown loamy soil, identical to the surrounding soil. No disturbances were noted. This feature is of unknown function and may have been disturbed by human activities such as grave preparation.

\section{FEATURE 4}

\section{Horizontal location: E1015.57 N1002.19}

Vertical location: $98.74-98.64$

Description: Feature 4 (Fig. 7,b) consisted of a tightly grouped concentration of deer antler directly overlying an infant burial, Burial 7. Six antler bases were recorded within the feature. Of these, only two could reasonably be matched to represent a single animal, based upon their proximity, physical appearance, and associated deer skull fragments. The other four bases were ordered in such a manner that some disturbance is indicated. It could not be determined if the four bases had been placed in the ground as racks or if they were already separated into single beams at the time of interment. Also, the sequence of placement could not be confidently determined. None of the antler was shed antler, and three to five individual deer could be represented within this feature. Based on interpretation of the plan drawing for the feature, at least one rack (two beams) of a white-tailed deer is represented in the feature (Caras 1967; Dasmann 1971). A rectangular mussel shell pendant, traces of red ocher, charcoal flecks, snail shells, flakes, and bone fragments were recovered from the fill. Soil matrix was a silty clay loam, identical to the surrounding soil.

\section{FEATURE 5}

Horizontal location: E1012.12 N1003.80

Vertical location: $\quad 98.46-98.31$

Description: Feature 5 (Fig. 14,a) was a partially excavated burned rock concentration located in the northwest corner of Unit E1012 N1002. From within the feature a total of 25 burned rocks weighed $4.3 \mathrm{~kg}$ from an area measuring $58 \times 28 \mathrm{~cm}$. Although the exact shape of the complete feature was not determined, the cross section of the exposed portions of the feature indicated a basin layer of larger rocks $(10 \mathrm{~cm}$ in size 


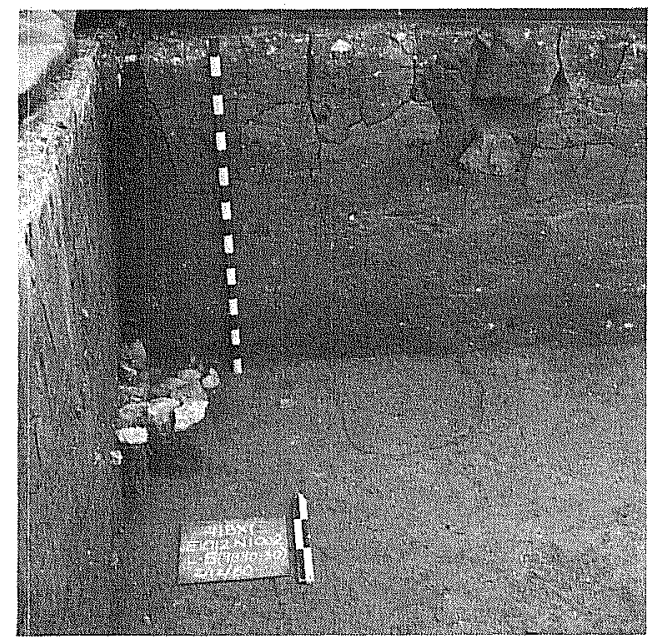

a

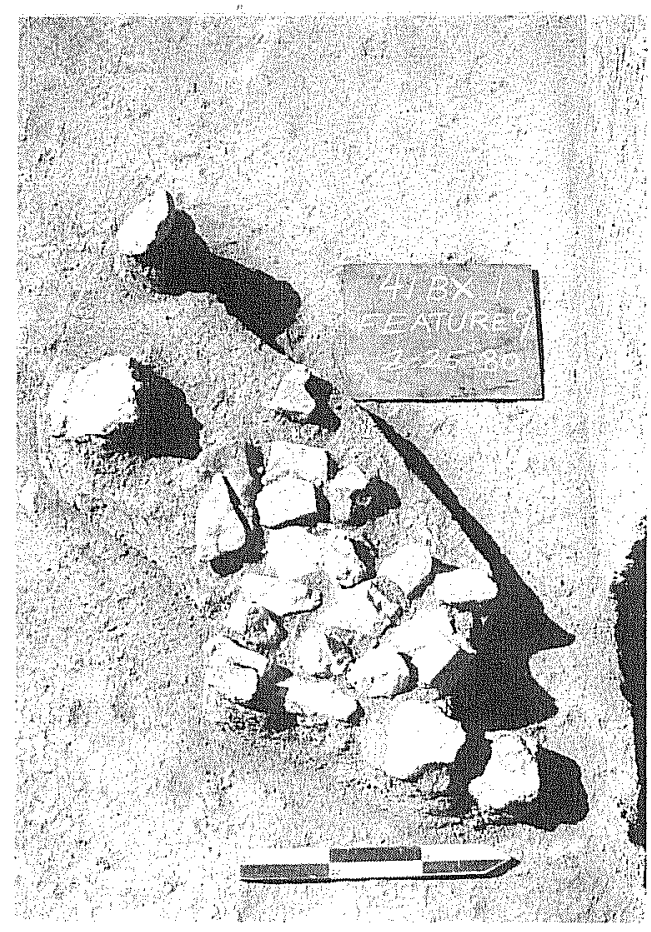

C

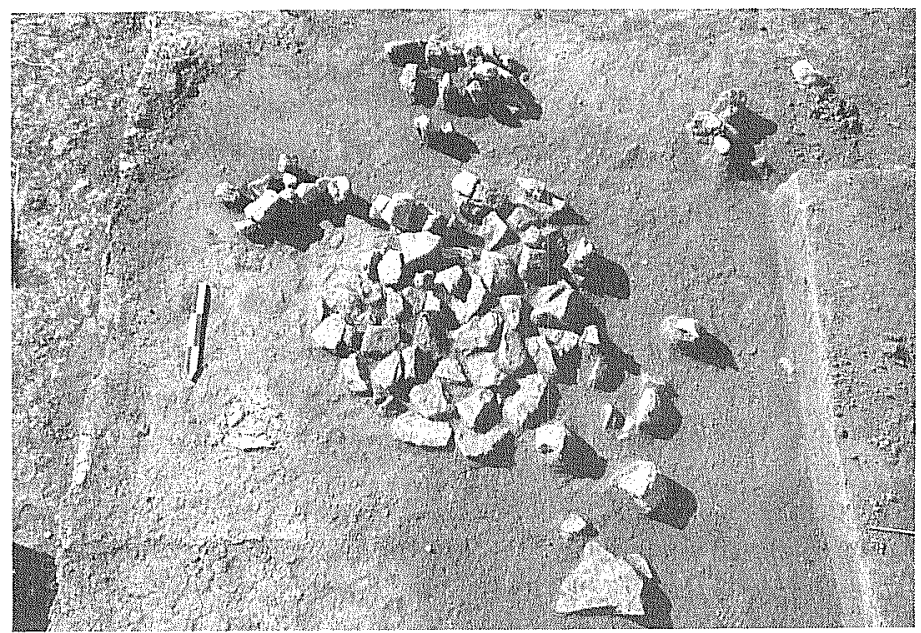

b

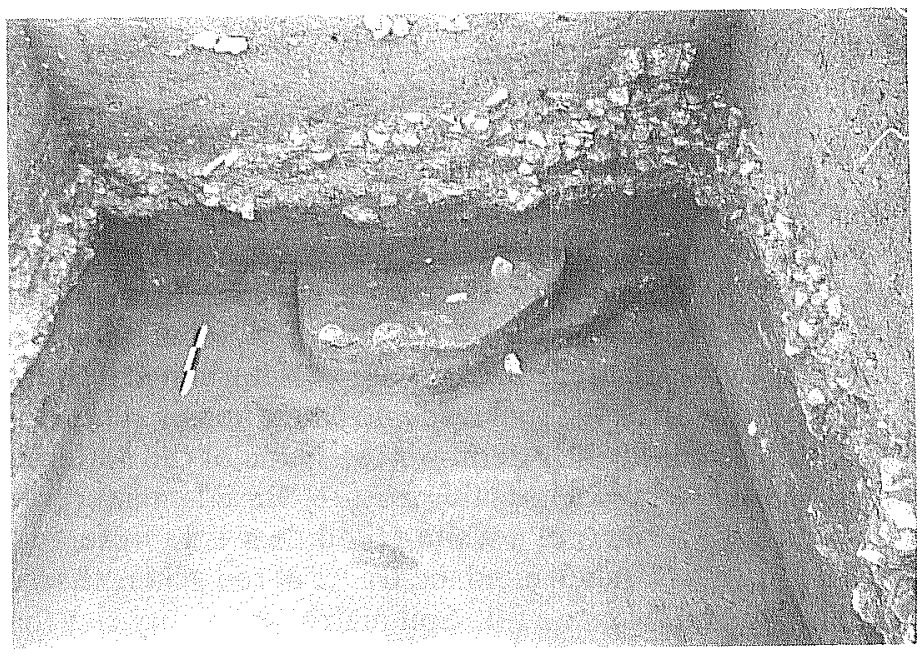

d

Figure 14. Features 5, 6, 8, 9 and 10 at 41 BX 1. a, Features 5 and 6; b, Feature 8; c, Feature 9; d, Feature 10. 
or smaller) overlain by a fewer number of smaller rocks. Feature fill included flakes, charcoal flecks, and snail shells. Soil matrix was the same as the surrounding soil, a light brown silty clay loam. Feature 5 is thought to represent the southwest quadrant of a roughly circular hearth similar to Feature 8.

\section{FEATURE 6}

\section{Horizontal location: E1012.73 N1003.78}

Vertical location: $\quad 98.30-97.90$

Description: Feature 6 (Fig. 14,a) consisted of a roughly circular stain of dark soil measuring $42 \times 40 \mathrm{~cm}$. The soil within the feature was a brown clay loam, darker than the surrounding soil. The feature matrix was also slightly more clayey in the first $10 \mathrm{~cm}$, but as the feature was followed through the corresponding unit-levels, soil texture increasingly matched that of the soil surrounding it. The stain grew increasingly less distinct and harder to define as depth of the feature increased. Screened fill from the feature included flakes, bone and antler fragments, hackberry seeds, snail shells, and a few burned rocks. Two recent seeds and an insect part were also recovered.

The presence of recent seeds and insect parts within the feature and the absence of a clearly definable termination tend to indicate that this is not a cultural feature.

\section{FEATURE 7}

\section{Horizontal location: E1013.82 N1002.20}

Vertical location: $\quad 98.27-98.16$

Description: A relatively loosely concentrated cluster of burned limestone rocks was in an area $60 \times 40 \mathrm{~cm}$. No specific patterning or layering of the rocks was noted. Twenty-one burned rocks averaging $3-9 \mathrm{~cm}$ in size and with a total weight of $2.1 \mathrm{~kg}$ were recorded within the feature. Artifacts recorded with the feature include a basal fragment of a projectile point (Miscellaneous Form 1), a proximal end of a biface, a retouched flake, a modified flake, unmodified flakes and chips, bone fragments, hackberry seeds, and snail shells. Soil was noted as a dark brown silty clay loam and undifferentiated from the soil throughout the same depth.

\section{FEATURE 8}

Horizontal location: E1012.96 N1000.80

\section{Vertical location: $\quad 98.36-98.24$}

Description: Feature 8 (Fig. 14,b) was a circular, slightly basined, tightly grouped concentration of burned limestone rocks associated with three smaller satellite burned rock concentrations. Size of the circular concentration measured $84 \times 81 \mathrm{~cm}$. Rocks within the circular concentration were set essentially in a single layer, although there were a few rocks in a second layer near the central portion of the feature. Sixty-three burned rocks with a total weight of $19.1 \mathrm{~kg}$ and averaging $10-15 \mathrm{~cm}$ in size were recorded within the circular concentration. The rocks tended to be tabular in shape. The three satellite concentrations were located south of the circular concentration. They tended to be on a less even plane, showed no internal patterning or structure, and the individual stones within each cluster tended to be smaller in size and more irregularly shaped than those in the circular concentration. Sizes of the clusters averaged either $45 \mathrm{x} 45 \mathrm{~cm}$ or $44 \mathrm{x}$ $27 \mathrm{~cm}$, and consisted of 5-21 pieces of burned rock. The weight range for the clusters was $0.5-2.1 \mathrm{~kg}$. Flakes, chips, bone fragments, a trace of mussel shell and charcoal, hackberry seeds, and snail shells were recovered 
from the fill screened from this feature. Soil matrix was the same as the surrounding soil, a brown silty clay loam.

\section{FEATURE 9}

Horizontal location: E1012.00 N1001.70

Vertical location: $98.22-98.14$

Description: Feature 9 (Fig. 14,c), a small cluster of burned limestone rocks, was in an 85- x 38-cm area, with the long axis northeast to southwest. The feature contained 32 burned rocks with a total weight of $5 \mathrm{~kg}$. The rocks were on a fairly even surface in a single layer and were irregularly shaped, varying in size from 5 to $10 \mathrm{~cm}$. A single core was associated with the feature in addition to flakes, chips, a turtle carapace, and snail shells. The soil within the feature was the same as the surrounding soil, a dark brown silty loam.

\section{FEATURE 10}

Horizontal location: E1030.30 N1001.20

Vertical location: $98.60-98.25$

Description: Feature 10 (Fig. 14,d) was a soil anomaly of thermally altered reddish brown soil interspersed with hardened clay nodules, charcoal chunks, and a few scattered burned rocks, all within a light brown silty clay loam. The feature was originally defined as being almost semicircular in outline, extending into the southwest corner of Unit E1029 N1001. However, as the feature was followed in successive levels, it gradually became less distinct and migrated towards the southwest corner of the unit. The first level that the feature was recorded in was $30 \mathrm{~cm}$ below a burned rock midden. The outline generally conformed to an area in the profile of the midden that contained a shallow depression and was characterized by less tightly compacted burned rock densities. This may indicate that the feature was intrusive from above or within the midden, possibly a burned tree root system.

Flakes and chips, burned rocks, burned and unburned bone fragments, burned clay, charcoal, hackberry seeds, and snail shells were recovered from the screened fill. The surrounding soil matrix was a light brown silty clay loam, similar to the surrounding soil, except for the presence of charcoal stains, hardened clay nodules, and reddish brown silty clay loam patches and mottling.

\section{FEATURE 11}

Horizontal location: Cluster 1 at E1023.65 N1065.55, Cluster 2 at E1023.78 N1065.25

Vertical location: $\quad 98.29-98.20$

Description: Feature 11 (Fig. 13,c) consisted of two associated burned limestone rock concentrations located in the eastern half of Unit E1022 N1065. The concentrations were designated Cluster 1 and Cluster 2 of Feature 11. Cluster $1,80 \times 53 \mathrm{~cm}$, was the northernmost and largest cluster. It contained 58 burned rocks that weighed $12.7 \mathrm{~kg}$. Cluster $2,42 \times 31 \mathrm{~cm}$, was located approximately $20 \mathrm{~cm}$ southeast of Cluster 1 . No internal patterning of burned rocks was noted within the feature clusters. Burned rocks varied in size from about 2 to $10 \mathrm{~cm}$ in average size.

Flakes and chips, unburned and burned bone fragments, charcoal flecks, hackberry seeds and one unidentifiable seed, a trace of mussel shell, and snail shells were recovered from the screened fill. Feature 
matrix was similar to the surrounding soil, a compact dark grayish brown clayey loam. The feature rested just above a soil change to a lighter, less clayey loam (soil zone 3 ).

\section{MATERIALS COLLECTED}

Material recovered at $41 \mathrm{BX} 1$ is divided into five major categories: lithics, ceramics, shell, bone, and antler. For all materials, where applicable, measurements are given in centimeters, and the following abbreviations are most commonly used for describing the dimensional traits in this report: ML designates maximum length, MW designates maximum width, and MT designates maximum thickness. Weight (WT) is in grams unless otherwise indicated. Other, less frequently used abbreviations are presented as necessary. Numbers enclosed by parentheses indicate the actual measurements on broken specimens and do not reflect the original nature of the specimen. Provenience of each artifact is either provided with the individual description or in table format in Appendix III.

\section{LITHICS}

Lithic materials ( 19,799 specimens) are represented by projectile points, cores, thin bifaces, distally beveled bifaces, thick bifaces, retouched flakes and chips, modified flakes and chips, unmodified debitage, ground and pecked stone, burned rock, limestone, clay, and unmodified materials. Whenever possible historic typologies have been used (see projectile points and distally beveled bifaces) as these offer the most readily acknowledged temporal parameters currently available. Otherwise categories are based on selected morphological and technological attributes.

\section{Projectile Points}

A total of 67 projectile points was recovered: 51 are identified as known types, 10 are classified as miscellaneous forms, and six are unidentifiable. Identification was based on a publication by Suhm and Jelks (1962). Only two specimens may be arrow points (Miscellaneous Form 7 and possibly the Zavala point type [cf. Hester 1980:108]).

\section{Angostura}

An incomplete specimen, heavily ground on the lateral sides is identified as an Angostura (Fig. 15,a). Dimensions: ML: (5.2), MW: 2.8, MT: 0.8. Provenience: E1012 N1002, 98.00-97.90.

Bell

The barbs have broken off; the blade is possibly reworked and irregular; and the slightly concave base is ground on the specimen classified as Bell (Fig. 15,b). Dimensions: ML: 5.4, MW: (4.1), MT: 0.7 . Provenience: E1012 N1002, 97.90-97.80.

\section{Bulverde}

A complete specimen with a contracting stem and a straight base is identified as a Bulverde (Fig. 15,c). The blades are slightly convex and taper to a needlelike point. Dimensions: ML: 7.9, MW: 3.4, MT: 0.6 . Provenience: E1010 N1000, 98.50-98.40. 


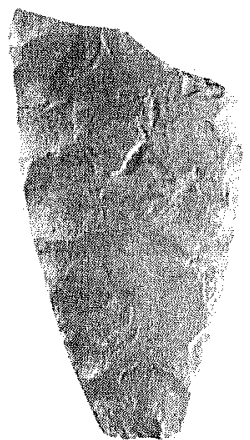

a

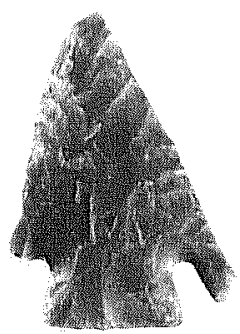

e

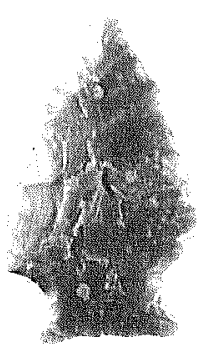

i

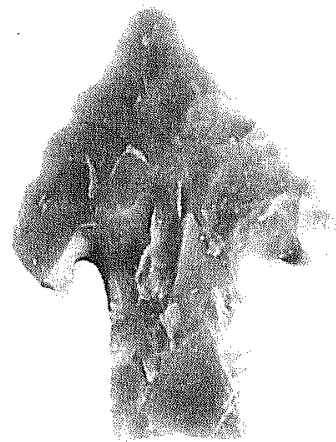

b

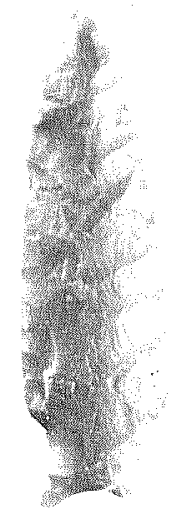

f

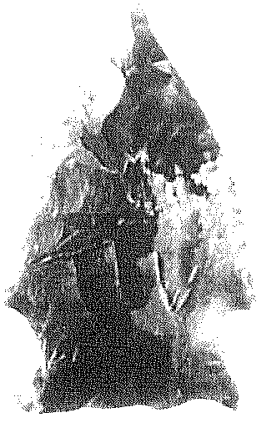

j

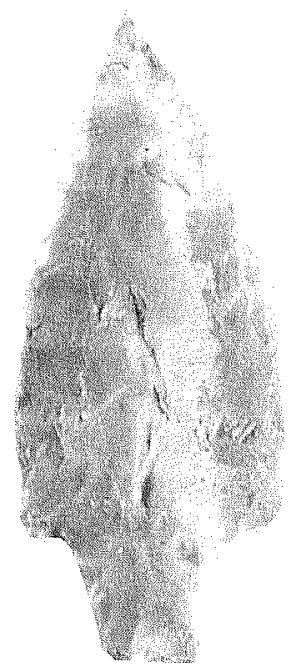

C

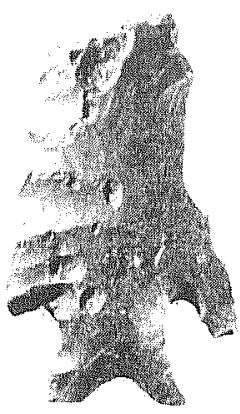

g

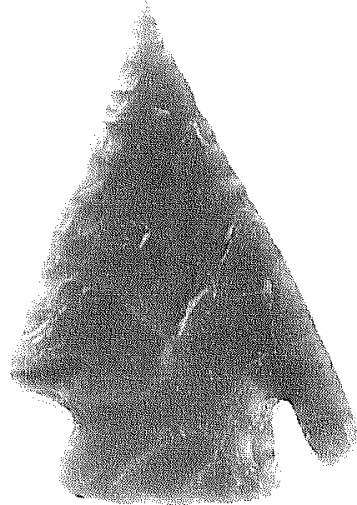

d

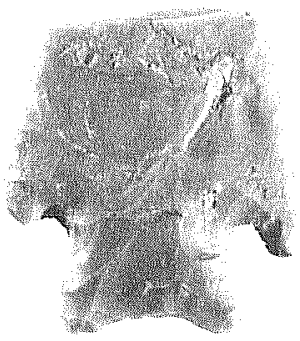

h

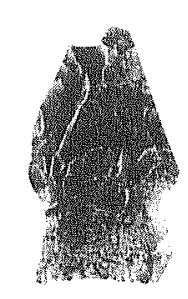

k

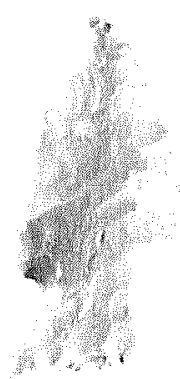

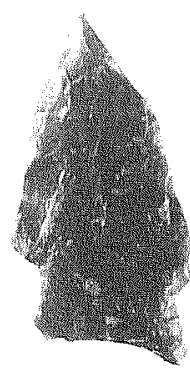

m

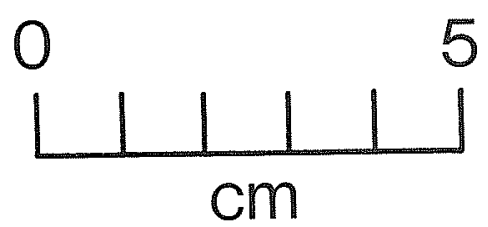

Figure 15. Projectile Points from 41 BX 1. a, Angostura; b, Bell; c, Bulverde; d,e, Castroville; f, Darl; g,h, Early Corner Notched; $\mathrm{i}, \mathrm{j}$, Ensor; k-m, Fairland. 


\section{Castroville}

All four specimens identilied as Castroville have broad triangular blades and broad, slightly expanding stems with slightly convex (three) to straight bases (one). When barbs remain they extend almost to the base. Cross sections are very thin relative to the width of the blade. One specimen is burned. Two specimens are shown in Figure 15,d,e. Dimensions: ML: 6.3-(3.3), MW: (4.3)-(2.4), MT: 0.6-0.5. Provenience: E1010 N1000, 98.60-98.50; E1010 N1000, 98.30-98.20; E1014 N1002, 98.70-98.60; E1016 N1001, 98.30-98.20.

\section{Darl}

One specimen with a long, slender, slightly convex blade, an expanding stem formed by wide, shallow notches, and a concave base is identified as a Darl projectile point (Fig. 15,f). Dimensions: ML: 6.7, MW: 1.7, MT: 0.7. Provenience: general surface collection.

\section{Early Corner Notched}

Two Early Corner Notched specimens (Fig. 15, g,h) with deep, narrow corner notches which form expanding stems were recovered from early contexts within the site. Barbs on these specimens would have extended more than halfway down the length of the base. One specimen has a relatively deep U-shaped notch placed toward the center of a straight base, and one specimen has an evenly concave base. One burned specimen is similar to Uvalde types (see Hester 1971:Fig. 10, m-s, Early Corner Notched, Variety 2). Dimensions: ML: (4.7)-(4.4), MW: 3.5-3.0, MT: 0.8-0.7. Provenience: E1012 N1002, 98.00-97.90; E1029 N1001, 98.60-98.50.

\section{Ensor}

All three specimens identified as Ensor have wide, shallow side notches; bases are very slightly (two) to strongly concave (one); and the serrated blades may be straight (two) or slightly concave. One specimen is reworked at the distal end. Two specimens are shown in Figure 15,i,j. Dimensions: ML: 5.0-3.5, MW: 3.2-2.5, MT: 0.6-0.5. Provenience: E1014 N1002, 98.60-98.50; E1022 N1065, 98.40-98.30; E1029 N1001, 99.30-99.20.

\section{Fairland}

All four specimens identified as Fairland have straight to slightly convex blades. The broad stems are formed by wide, shallow side notches. The bases are concave. On all specimens, one side of the stem is longer than the other when held vertically, oriented with the axis running from the tip to the center of the base. One specimen is burned. Three specimens are shown in Figure 15,k-m. Dimensions: ML: (4.7)-(3.4), MW: 2.6-2.1, MT: 0.6-0.4. Provenience: E1010 N1000, 98.40-98.30; E1011 N999, 98.60-98.50; E1012 N1002, 98.50-98.40; E1029 N1001, 99.30-99.20.

Frio

Eight specimens identified as Frio have side notches with widely flaring stems. The bases may be convex, straight, or concave, but all show a deep basal concavity or notch in the center of the base. Two specimens are burned. One specimen has a thick biconvex cross section on a long narrow blade and is probably a drill or punching tool. Three specimens are shown in Figure 16,a-c. Dimensions: ML: 7.2-(2.0), MW: (3.0)-(1.3), MT: 0.7-0.4. Provenience: E1012 N1001, 98.70-98.60; E1012 N1002, 98.10-98.00; E1013 N998, 94.41-98.30 (2); E1014 N1001, 98.60-98.50; E1022 N1065, 98.30-98.20 (2); general surface collection. 


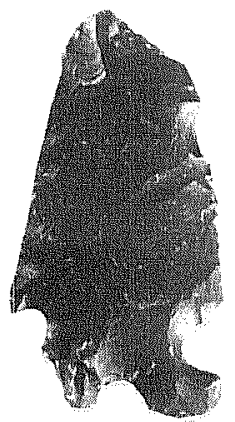

a

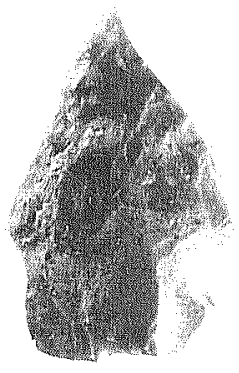

f

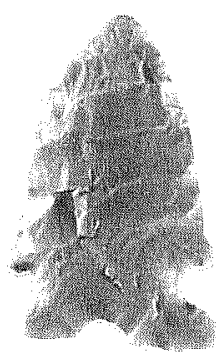

b

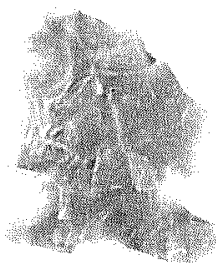

C

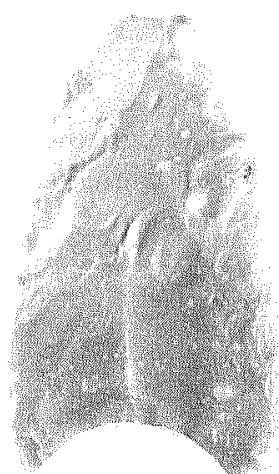

d

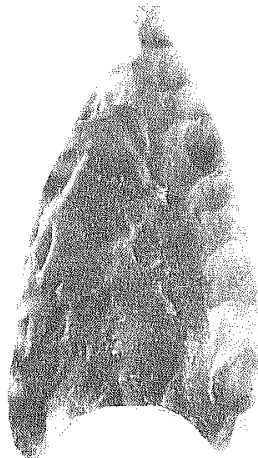

e
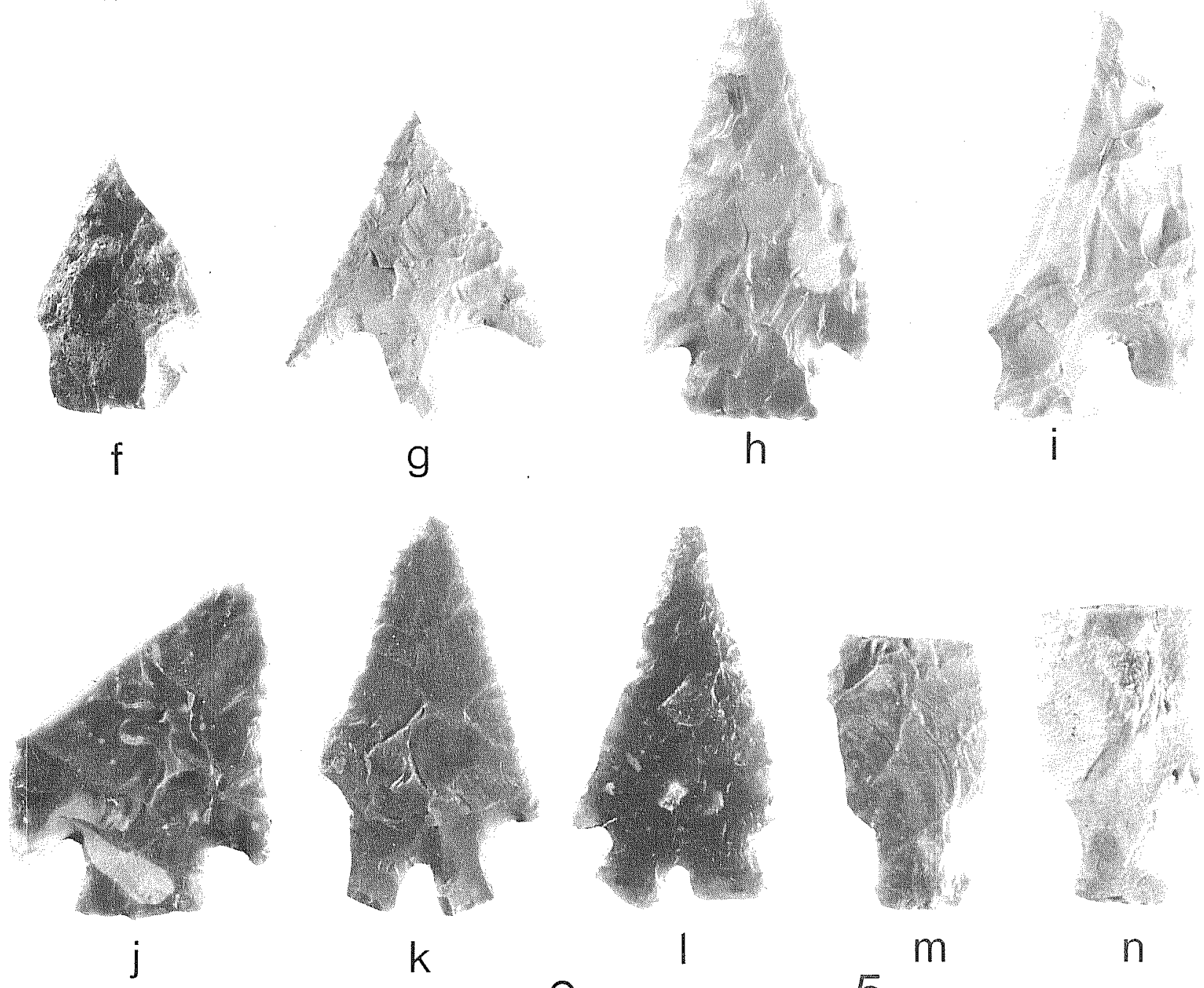

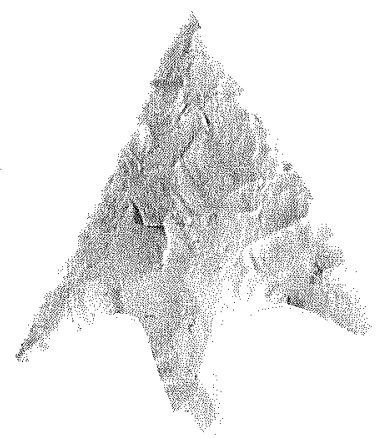

g h

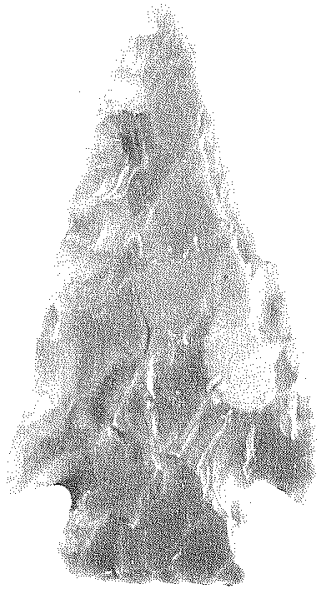

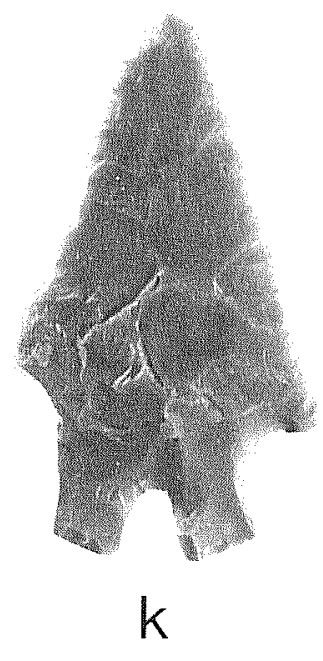

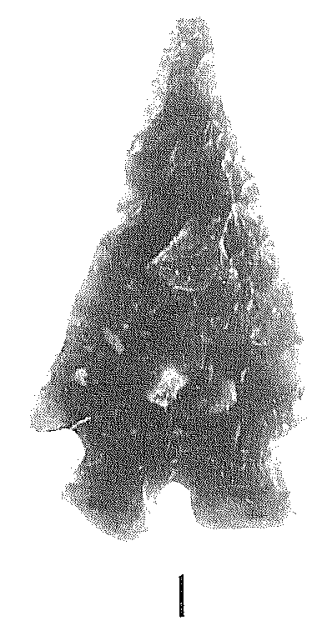

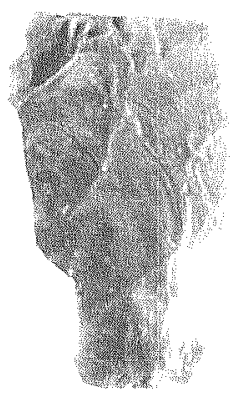

m

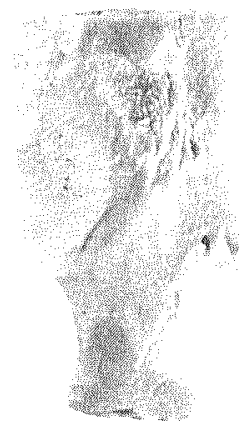

n

0

5

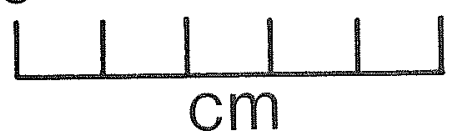

Figure 16. Projectile Points from 41 BX 1. a-c, Frio; d,e, Kinney; f, La Jita; g, Langtry; h, Lange; i,j, Marshall; k, , Montell; m, n, Nolan. 
Kinney

Three specimens identified as Kinney have broad blades with convex edges and concave bases. Two specimens are shown in Figure 16,d,e. Dimensions: ML: 6.0-(5.6), MW: 3.7-3.1, MT: 0.8-0.6. Provenience: E1022 N1065, 99.10-99.00; E1022 N1065, 98.90-98.80; general surface collection.

\section{La Jita}

One specimen with a short triangular blade and a slightly expanding stem, which is alternately beveled on the right side, is identified as a La Jita (Fig. 16,f). The base is slightly convex, and the corners are rounded. The specimen has some similarities to the Nolan type (cf. Hester 1971:74). Dimensions: ML: 4.4, MW: 2.7, MT: 0.8. Provenience: E1012 N999, 98.30-98.20.

\section{Lange}

One specimen with a triangular blade, straight edges, an expanding stem, and a straight base is identified as a Lange (Fig. 16,h). The specimen is similar to the Castroville type, but the blade width is proportionally narrower in relationship to length, and the cross section is thicker. Dimensions: ML: 7.4, MW: 3.9, MT: 0.9. Provenience: E1029 N1001, 99.00-98.90.

\section{Langtry}

One specimen identified as a Langtry (Fig. 16,g) has a broad triangular blade with straight edges and strong barbs, and the stem is relatively narrow and contracts to form a rounded base. Dimensions: ML: 5.2, MW: 4.5, MT: 0.5. Provenience: E1029 N1001, 98.90-98.80.

\section{Marshall}

The two specimens identified as Marshall (Fig. 16,i,j) have broad blades with either straight or convex edges; the stems are slightly expanding and formed by apparent basal notches that have removed the corners at the stem. The bases are slightly convex. Dimensions: ML: (7.0)-(5.9), MW: 4.5-(3.7), MT: 0.8. Provenience: E1014 N1002, 98.40-98.30; Backhoe Trench 21.

\section{Montell}

All three specimens identified as Montell have moderately long, straight to slightly convex edges. The cross sections are unusually thin. The expanding stems have been centrally notched, and at one time probably had convex bases. One specimen is reworked along the upper two-thirds of the blade. Two specimens are shown in Figure 16,k,1. Dimensions: ML: (7.4)-6.3, MW: 3.8-3.5, MT: 0.7-0.5. Provenience: E1010 N1000, 98.20-98.10; E1012 N1002, 98.50-98.40; E1014 N1001, 98.20-98.10.

\section{Nolan}

Two of the three Nolan specimens have relatively long narrow blades with slightly convex or concave edges. Both specimens have alternately right-handed bevels on slightly expanding stems, and the bases are straight. Two specimens are shown in Figure 16,m,n. Dimensions: ML: (5.1)-(2.8), MW: 2.9-2.4, MT: 1.0-0.5. Provenience: E1012 N999, 98.20-98.10; E1012 N1002, 97.90-97.80; E1014 N999, 98.25-98.10. 


\section{Pedernales}

All eight specimens identified as Pedernales have generally triangular blades with straight to slightly convex edges; the stems are straight to contracting; and the bases are concave. A single specimen has an unusually broad blade. Five specimens are shown in Figure 17,a-e. Dimensions: ML: 7.1-6.9, MW: 5.4-2.9, MT: 1.1-0.7. Provenience: E1012 N1002, 98.70-98.60; E1012 N1002, 98.60-98.50; E1014 N1002, 98.30-98.20; E1029 N1001, 99.00-98.80 (2); F. S. Burial; Area B surface; general surface collection.

\section{Travis}

One burned specimen identified as a Travis (Fig. 17,f) has a narrow blade with slightly convex edges. The stem is formed by very shallow chipping, forming a relatively long, slightly expanding stem with a rounded, convex, ground base. Dimensions: ML: (5.2), MW: 2.9, MT: 1.1. Provenience: E1029 N1001, 98.50-98.40.

\section{Triangular Projectile Points}

Triangular blades with straight to slightly concave bases are characteristics of the two specimens classified as Triangular projectile points (Fig. 17,g,h). One specimen has a single right-handed bevel; the other specimen has bevels along either edge of one face. The smaller specimen is clearly basally thinned. Dimensions: ML: 4.6-4.4, MW: 3.1-2.2, MT: 0.7. Provenience: E1012 N1002, 98.70-98.60; E1012 N1002, 98.00-97.90.

\section{Zavala}

One specimen identified as Zavala has a small, short point with a triangular blade and shallow side notches which form an expanding stem with distinct edges. The base is straight (cf. Hester 1980:108). Dimensions: ML: (2.3), MW: 2.2, MT: 0.5. Provenience: Area A surface.

\section{Miscellaneous Forms}

Ten specimens could not be placed into known typological categories. They are described as forms.

FORM 1. All three Form 1 specimens (Fig. 17,i-k) are fragmentary. The blade forms could not be identified, but they appear to be relatively broad. The stems are widely expanding, formed by narrow to shallow corner notches; and the bases are concave. Form 1 specimens are vaguely reminiscent of large Ensor/Fairland types. Dimensions: ML: (4.9)-(2.7), MW: 3.7-(3.3), MT: 0.7. Provenience: E1012 N1002, 98.60-98.50; E1029 N1001, 98.90-98.80; Feature 7.

FORM 2. The Form 2 specimen (Fig. 18,a) is nearly complete with a long, broad blade and slightly convex edges. The stem is unusually short and formed by basal notches. The base is slightly concave; basal thinning flake scars are on both faces. Dimensions: ML: 9.7, MW: 4.4, MT: 0.8. Provenience: E1022 N1065, 99.20-99.10.

FORM 3. The Form 3 specimen (Fig. 18,b) is roughly made with irregular edges on a thick blade; an expanding stem is formed by wide shallow side notches, and the base has a deep concavity. Dimensions: ML: (5.5), MW: 3.8, MT: 1.1. Provenience: E1012 N1002, 98.40-98.30.

FORM 4. The Form 4 specimen (Fig. 18,c) has a relatively long, narrow blade with slightly convex edges and an expanding, almost rounded, stem formed by wide side notches. The base is damaged, but it appears to be strongly convex. The specimen has strong similarities to Palmillas and Godley points (cf. Jelks 1962, 


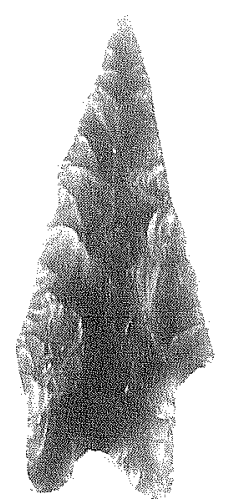

a

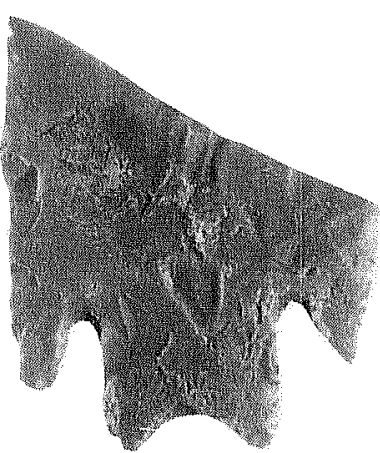

e

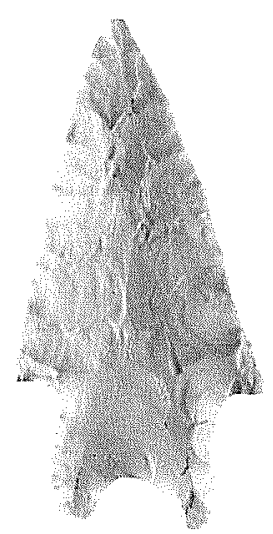

b

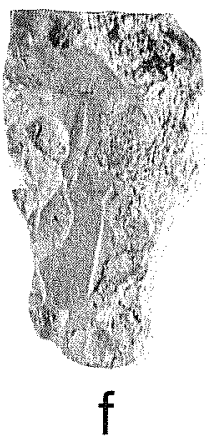

k

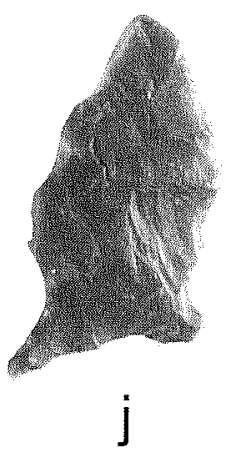

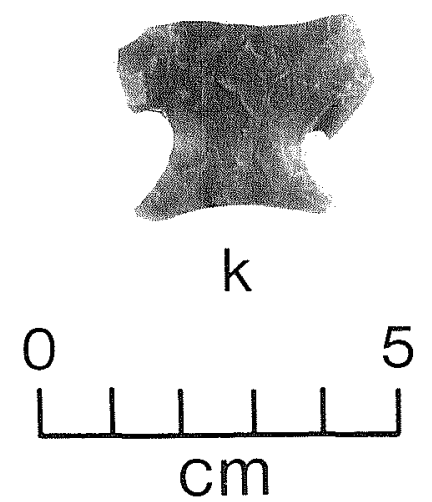

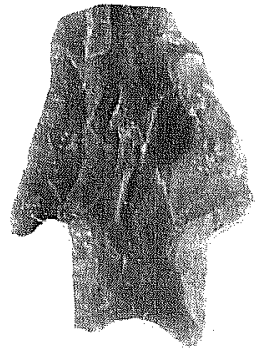

C
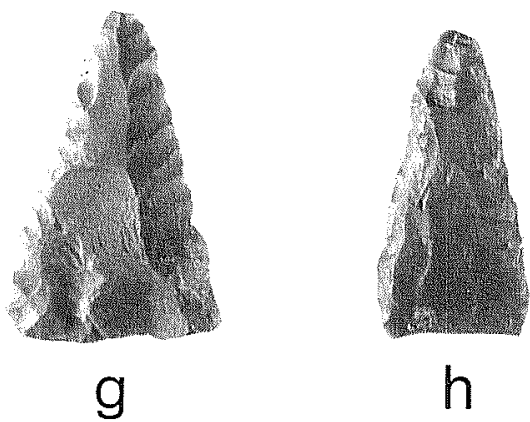

$\mathrm{h}$
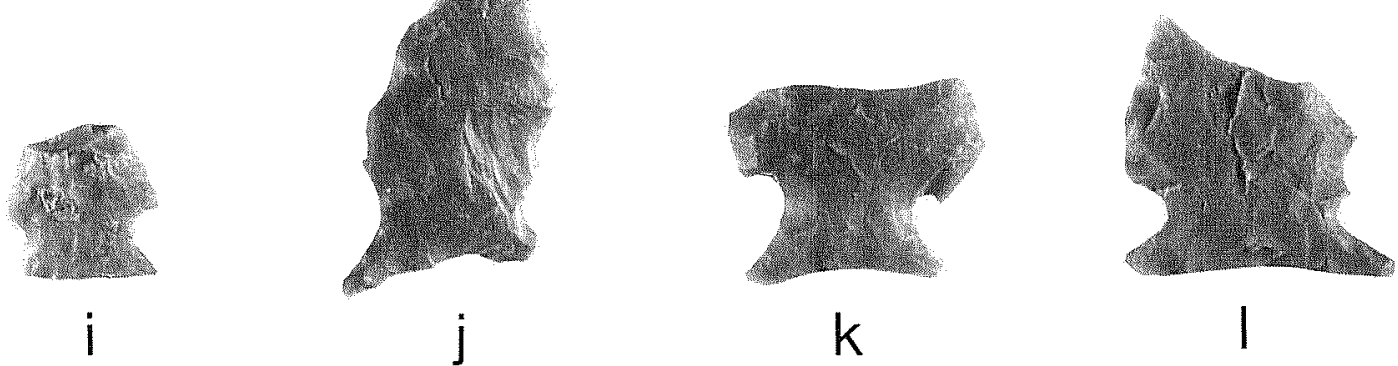

Figure 17. Projectile Points from 41 BX 1. a-e, Pedernales; $\mathrm{f}$, Travis; g,h, Triangular; i,k, Miscellaneous Form 1. 


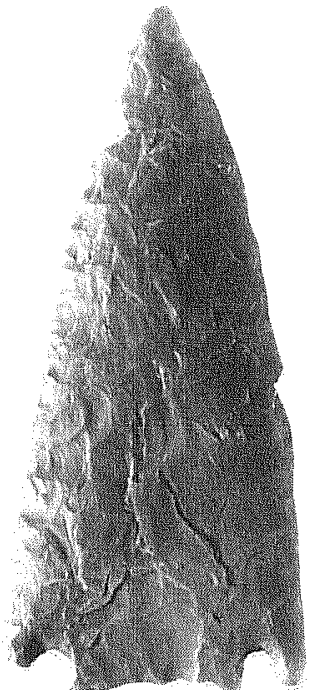

a

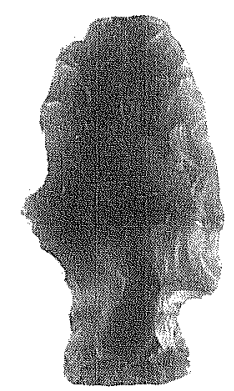

e

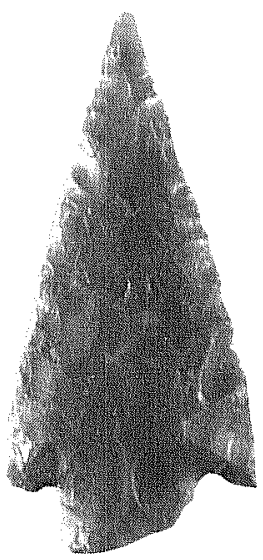

i

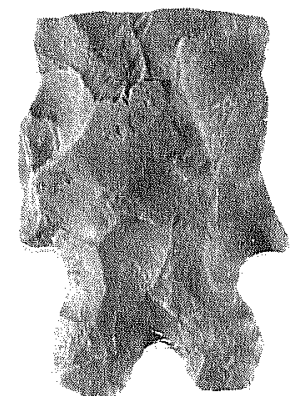

b

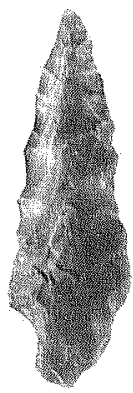

C

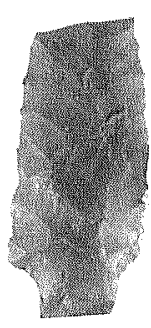

d

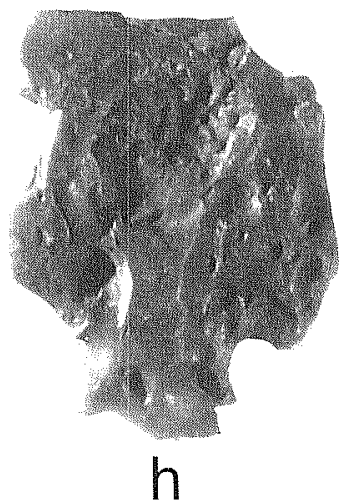

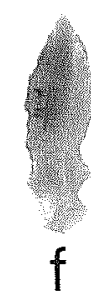

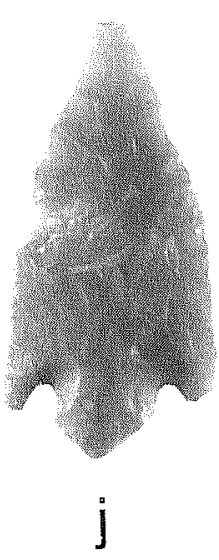

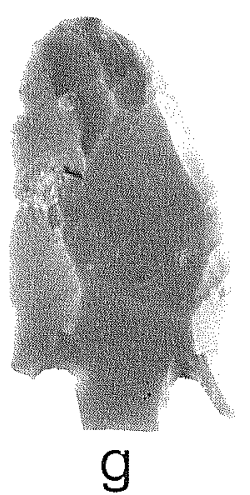
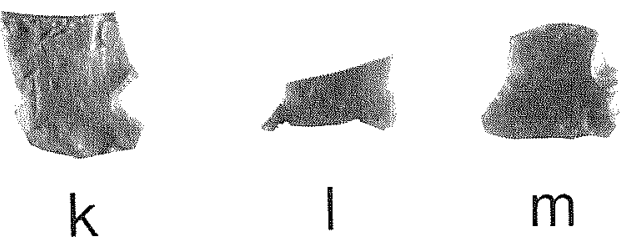

m

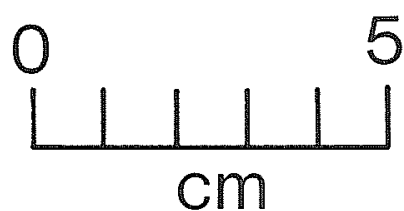

Figure 18. Miscellaneous Projectile Point Forms and Fragments from 41 BX 1. a, Form 2; b, Form 3; c, Form 4; d, Form 5; e, Form 6; f, Form 7; g, Form 8; h-m, miscellaneous unidentified point fragments. 
Fig. 15,L and Fig. 16,A-E). This specimen was directly associated with Burial 5A. Dimensions: ML: 5.4, MW: 1.8, MT: 0.7. Provenience: Burial 5A.

FORM 5. The Form 5 specimen (Fig. 18,d) has some similarities to Form 4; however, the blades are clearly serrated, and the stem is formed by corner notches. The base is straight. Dimensions: ML: 4.3, MW: 2.2, MT: 0.6. Provenience: E1014 N997, 98.19-98.10.

FORM 6. The Form 6 specimen (Fig. 18,e) is roughly made with one convex blade edge, and the other edge is damaged. The expanding stem has a slightly convex base. Dimensions: ML: 5.4, MW: 3.0, MT: 0.9. Provenience: E1029 N1001, 99.00-98.90.

FORM 7. The Form 7 specimen (Fig. 18,f) is an eccentric arrow point made on a flake edge and unifacially retouched on alternate faces just enough to shape the flake. The blades are convex, and the base is rounded. Two barbs are formed between the blades and the base by two shallow side notches on both sides of the specimen. Dimensions: ML: 3.3, MW: 1.2, MT: 0.2. Provenience: Area B surface.

FORM 8. The Form 8 specimen (Fig. $18, \mathrm{~g}$ ) is a minimally worked flake with irregularly convex blade edges forming a rounded distal end. The straight stem is formed by basal notches, and the base is slightly concave. Dimensions: ML: 6.0, MW: 3.5, MT: 0.6. Provenience: E1012 N1002, 98.10-98.00.

\section{Miscellaneous Unidentified Point Fragments}

Six point fragments (Fig. 18,h-m) could not be identified further. Three are small basal fragments that have expanding stems with slightly concave to straight bases. They are reminiscent of very Late Archaic types like Ensor, Ellis, Edgewood, and Fairland. Two specimens are primarily blades, although approximately one-half of the stem is present. Both are probably expanding stem points. One specimen is burned, and just enough of two notches are present to identify it as a point. Dimensions are not recorded. Provenience: E1010 N1000, 98.60-98.50 (2); E1010 N1000, 98.10-98.00; E1012 N1002, 98.40-98.30; E1012 N1002, 98.30-98.20; E1022 N1065, 98.30-98.20.

Cores

Cores are chert nodules or cobbles from which three or more flakes have been removed. Generally, cores have less than a total of 10 flakes removed and tend to be blocky in shape. Sixty-three core specimens were recovered.

Subgroups are based on platform types and direction of flake removal. The six subgroups are natural platform cores; natural and prepared platform cores; bifacial cores; prepared platform, single directional cores; prepared platform, multidirectional cores; and core fragments.

\section{Natural Platform Cores}

Three specimens identified as natural platform cores have three or more flake scars struck from a cortex platform. They vary from gray to grayish brown. Two specimens are shown in Figure 19,a,b. Dimensions: ML: 11.7-8.1, MW: 7.1-5.5, MT: 4.9-3.5. Provenience: E1012 N1002, 97.80-97.70; E1014 N1001, 98.20-98.10; Feature 8.

Natural and Prepared Platform Cores

A total of 11 natural and prepared platform cores was recovered. Five of the 11 specimens have natural platforms of either relatively recent geological brcaks or of heavily patinated flake scars, indicating reuse of 


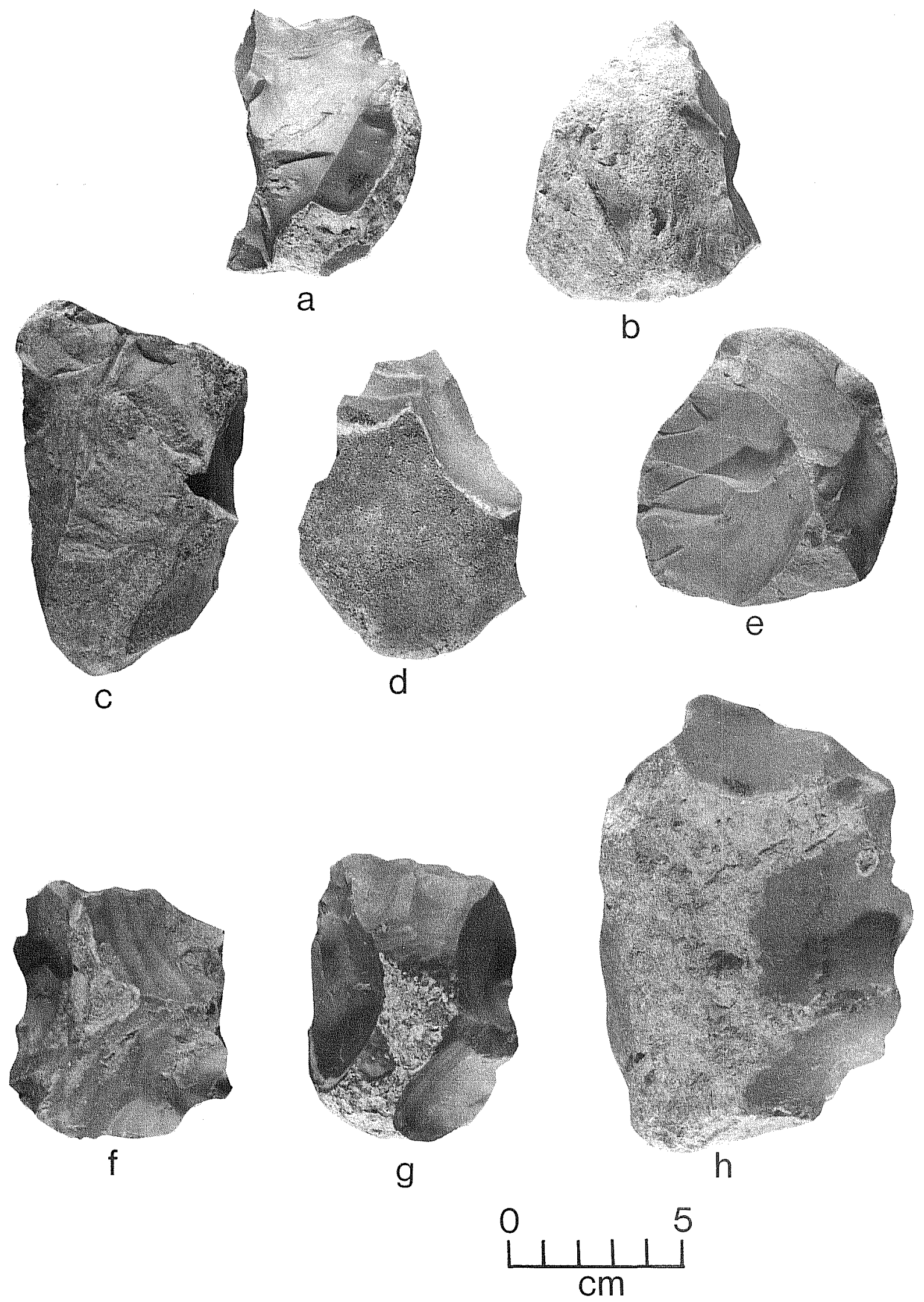

Figure 19. Cores from $41 B X 1$. a,b, natural platform cores; c-e, natural and prepared platform cores; f-h, bifacial cores. 
older cores, or taking advantage of relatively recent geological breaks. They vary from gray to grayish brown. Three specimens are shown in Figure 19,c-e. Dimensions: ML: 11.4-4.9, MW: 8.8-4.8, MT: 5.2-3.1. Provenience: E1010 N1000, 98.50-98.40; E1013 N1001, 99.00-98.90; E1014 N1002, 98.60-98.50; E1029 N1001, 99.30-99.20 (2); Area A surface (2); Area B surface (4).

\section{Bifacial Cores}

Bifacial cores exhibit a sinuous edge formed by the removal of a series of alternating flakes, creating alternating platforms along the margins of the core. All eight specimens retain some cortex. Three specimens are shown in Figure 19,f-h. Dimensions: ML: 12.8-6.1, MW: 9.1-4.3, MT: 5.5-1.3. Provenience: E1010 N1000, 98.70-98.60; E1010 N1000, 98.10-98.00; E1013 N1001, 98.80-98.70; E1014 N1002, 98.50-98.40; E1016 N1001, 98.30-98.20; E1022 N1065, 99.40-99.30; Feature 9; Area B surface.

\section{Prepared Platform, Single Directional Cores}

Two core specimens (Fig. 20, a,b) have two or more flakes struck in a single direction forming a single-faceted platform. Both specimens are grayish and have at least $50 \%$ of the cortex remaining. Dimensions: ML: 8.5-5.4, MW: 6.0-4.4, MT: 4.2-3.9. Provenience: E1011 N999, 98.70-98.60; E1013 N1001, 98.50-98.40.

\section{Prepared Platform, Multidirectional Cores}

Nineteen core specimens have prepared platforms with flake scars in two or more directions, but not creating the sinuous bifacial edges of bifacial cores. Six specimens are decorticate. They vary from gray to grayish brown to brown. Three specimens are shown in Figure 20,c-e. Dimensions: ML: 9.2-5.2, MW: 7.5-4.2, MT: 6.2-2.4. Provenience: E1010 N1000, 98.70-98.60; E1010 N1000, 98.40-98.30; E1012 N1002, 98.30-98.20; E1012 N1002, 98.20-98.10 (2); E1012 N1002, 98.10-98.00; E1014 N1002, 98.40-98.30; E1014 N1002, 98.30-98.20 (2); E1014 N1002, 98.20-98.10; E1015 N1000, 98.40-98.30; E1022 N1065, 99.40-99.30; E1022 N1065, 99.30-99.20; E1029 N1001, 99.38-99.30; E1029 N1001, 99.00-98.90; E1029 N1001, 98.90-98.80; E1029 N1001, 98.50-98.40; Burial 10; general surface collection.

\section{Core Fragments}

Core fragments are angular pieces of chert showing no recognizable flake scar patterns. Three specimens are decorticate. Three specimens are shown in Figure 20,f-h. Dimensions: ML: 13.0-3.0, MW: 7.1-2.8, MT: 4.0-0.3. Provenience: E1012 N998, 98.44-98.40; E1012 N1002, 98.70-98.60; E1013 N1001, 98.40-98.30; E1014 N1002, 98.70-98.60; E1014 N1002, 98.40-98.30; E1015 N1000, 98.20-98.10; E1015 N1001, 98.20-98.10; E1022 N1065, 99.75-99.50; E1022 N1065, 99.50-99.40; E1022 N1065, 99.10-99.00; E1029 N1001, 98.80-98.70; E1029 N1001, 98.60-98.50; E1029 N1001, 98.40-98.30; E1029 N1001, 98.30-98.20; E1029 N1001, 98.00-97.90 (3); E1029 N1001, 97.50-97.40; Trench 19; Area A surface.

\section{$\underline{\text { Thin Bifaces }}$}

Seventy-six thin bifaces were recovered, and they are divided into seven categories. They are generally descriptive of edge forms (convex, concave, or straight), or of a section of a biface (basal section, midsection, pointed end fragments, etc.), or some combination of the two. All specimens are less than $1.5 \mathrm{~cm}$ thick. All material is of chert. 

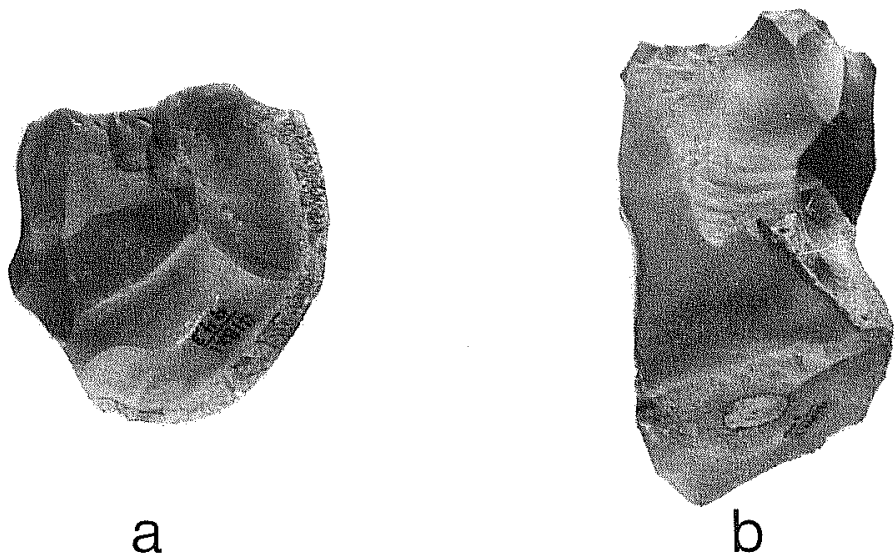

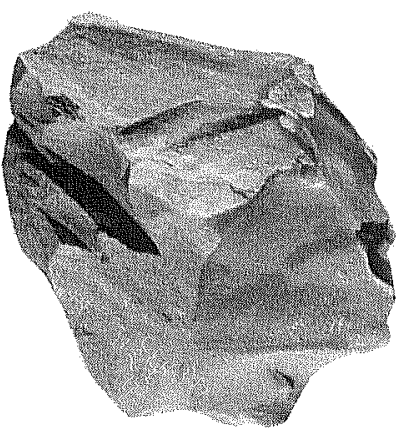

C

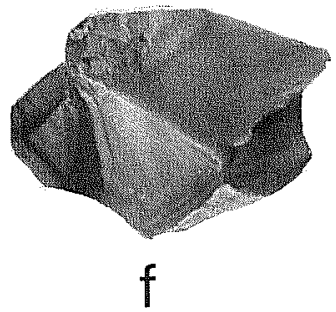

f
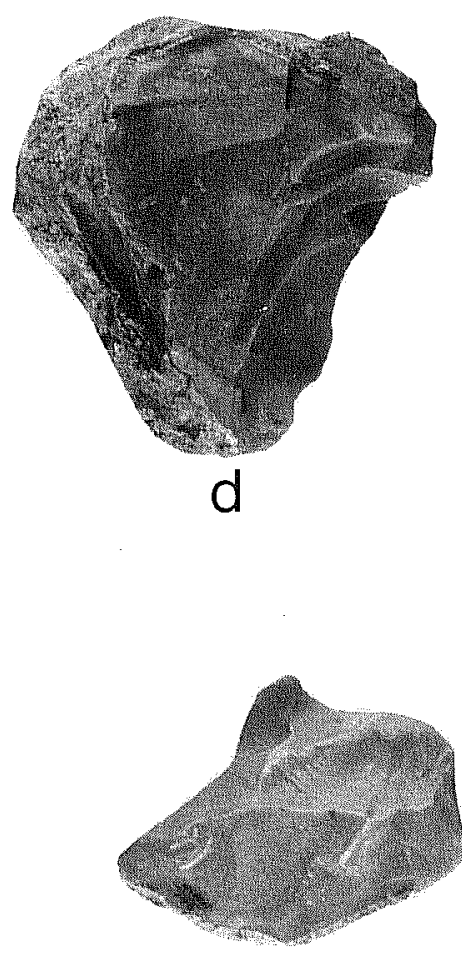

g

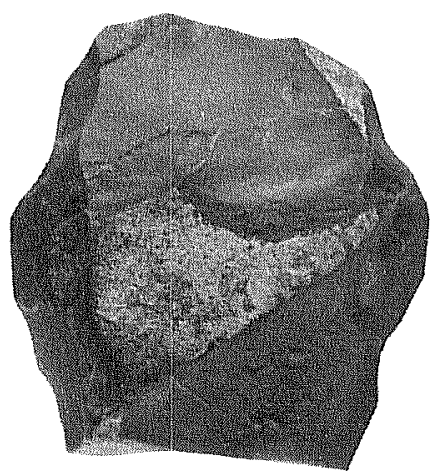

e

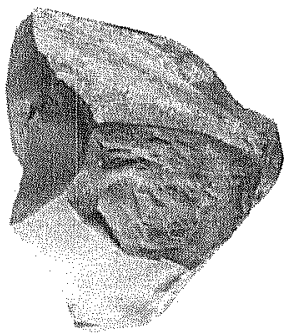

h

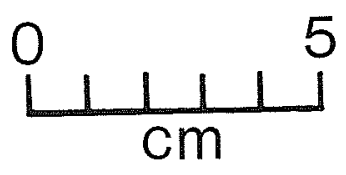

Figure 20. Cores from $41 B X 1$. a,b, prepared platform, single directional cores; c-e, prepared platform, multidirectional cores; f-h, core fragments. 
Convex Base

The 10 thin bifaces with convex bases are generally pointed ovate to ovate in outline, although edge forms may vary. Specimens $1-5$ have a single convex and a single irregular blade edge form. The irregular edges of these five specimens show step and hinge fractures, or "knobs" that indicate some difficulty in thinning at least one face of the specimen. It may be that these specimens are unfinished blanks or failures. Of the remaining specimens, three have convex edge forms, one has straight edges, and one has a recurved and an irregular blade form. All 10 specimens are decorticate. Each specimen is individually described.

SPECIMEN 1 (Fig. 21,d). Convex and irregular blades. Roughly broad-pointed ovate outline. Material is a light gray chert. Dimensions: ML: 7.2, MW: 5.6, MT: 1.2, WT: 51.9. Provenience: E1014 N1002, 98.40-98.30.

SPECIMEN 2 (Fig. 21,a). Convex and irregular blades. Material is a dark reddish gray chert. Dimensions: ML: 7.0, MW: 4.2, MT: 1.2, WT: 39.1. Provenience: E1029 N1001, 98.80-98.70.

SPECIMEN 3 (Fig. 21,j). Convex and irregular blades. Material is a gray chert. Dimensions: ML: 5.1, MW: 3.1, MT: 0.7, WT: 10.8. Provenience: E1012 N1002, 98.50-98.40.

SPECIMEN 4 (Fig. 21,h). Convex and irregular blades. Material is a reddish brown chert. Dimensions: ML: 9.4, MW: 3.9, MT: 1.4, WT: 45.7. Provenience: E1029 N1001, 98.50-98.40.

SPECIMEN 5 (Fig. 21,g). Convex and irregular blades. Strongly plano-convex cross section. Material is a light gray chert. Dimensions: ML: 6.9, MW: 2.4, MT: 0.8, WT: 12.0. Provenience: E1010 N1000, 98.10-98.00.

SPECIMEN 6 (Fig. 21,f). Convex blades. Proximal end of biface is heavily ground. Material is a light brown chert. Dimensions: ML: 6.1, MW: 3.7, MT: 0.8, WT: 16. Provenience: E1010 N1000, 98.20-98.10.

SPECIMEN 7 (Fig. 21,e). Convex blades. Material is a light reddish brown. Dimensions: ML: 6.9, MW: 3.9, MT: 0.8 , WT: 18.2. Provenience: general surface collection.

SPECIMEN 8 (Fig. 21,c). Convex blades; very narrow ovate outline. Material is a very pale brown chert. Dimensions: ML: (4.9), MW: 2.4, MT: 1.2; WT: 13.9. Provenience: E1029 N1001, 98.40-98.30.

SPECIMEN 9 (Fig. 21,b). Straight blades. Material is a pinkish gray chert. Dimensions: ML: (5.3), MW: 4.5, MT: 0.9, WT: 26.4 Provenience: E1010 N1000, 98.50-98.40.

SPECIMEN 10 (Fig. 21,i). Recurved and irregular blades. Material is a light gray chert. Dimensions: ML: 9.4, MW: 5.2, MT: 1.0, WT: 46.3. Provenience: Burial 2, 98.37.

\section{Straight Base}

Five thin bifaces with straight bases are identified as a complete drill, two roughly triangular specimens, and two broken specimens that have parallel edges. All five specimens are decorticate.

SPECIMEN 1 (Fig. 22,f). Recurved blades taper towards the distal end to form a thin slender point that could have served as a drill or punching tool. Material is a light grayish brown chert. Dimensions: ML: 6.8, MW: 3.3, MT: 0.8, WT: 16.8. Provenience: Trench 19, 98.30.

SPECIMEN 2 (Fig. 22,g). Slightly convex blades form a triangular outline. Material is a very pale brown chert. Dimensions: ML: 7.5, MW: 3.1, MT: 0.7, WT: 16.3. Provenience: E1029 N1001, 99.30-99.20. 


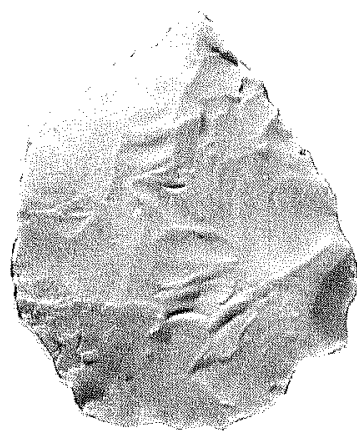

a
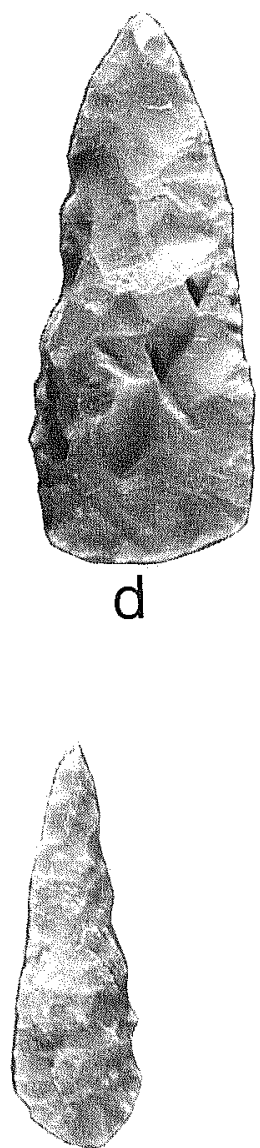

g

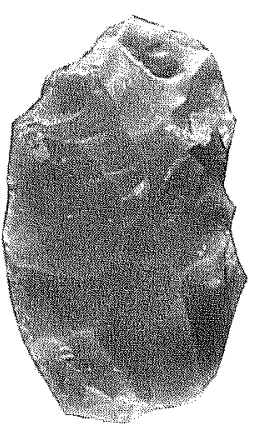

b
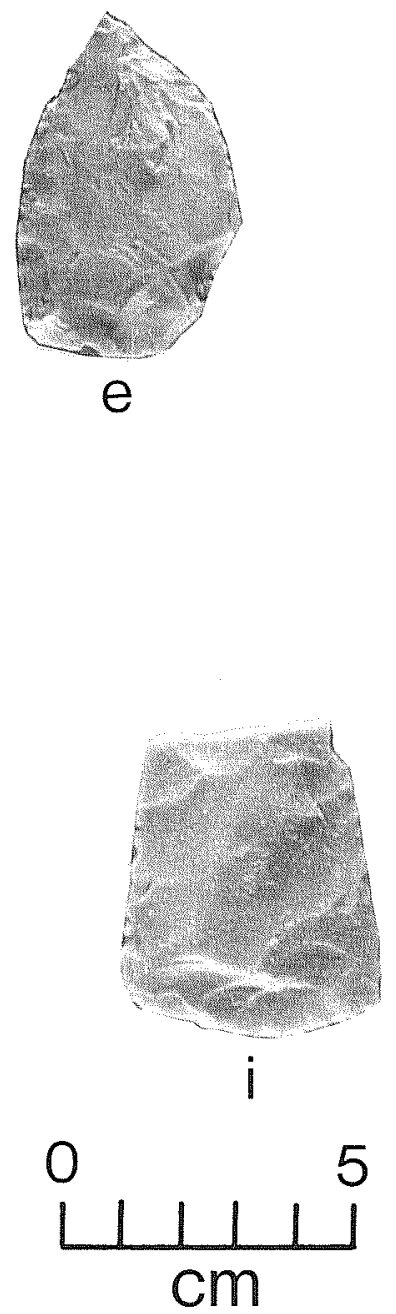

5

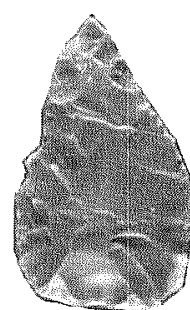

C
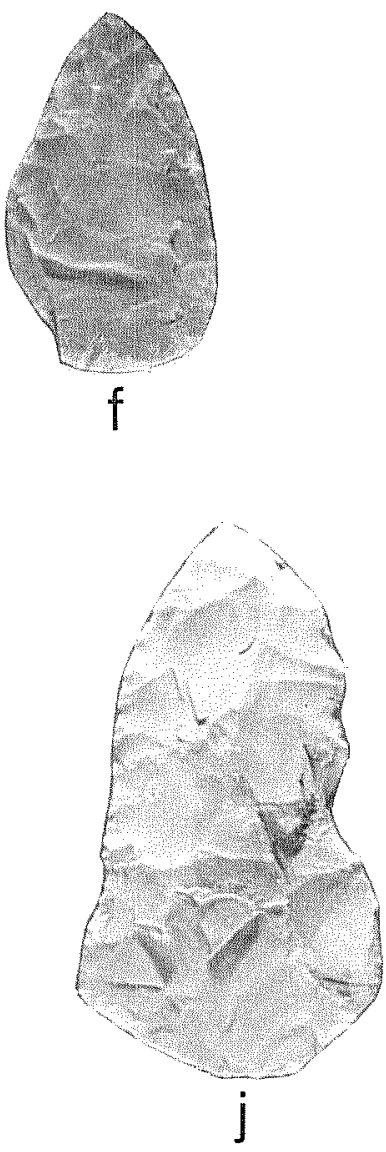


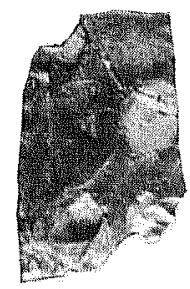

a
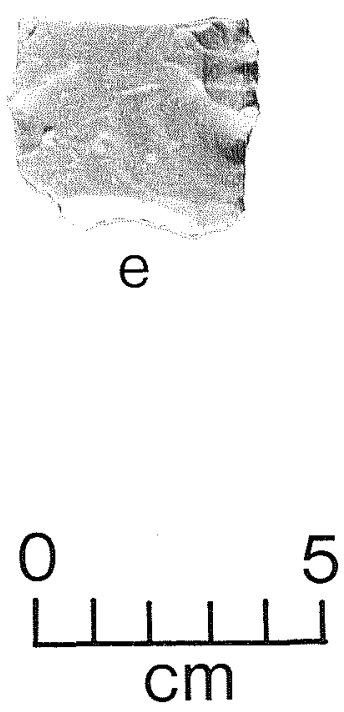

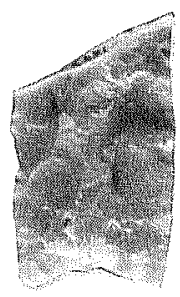

b
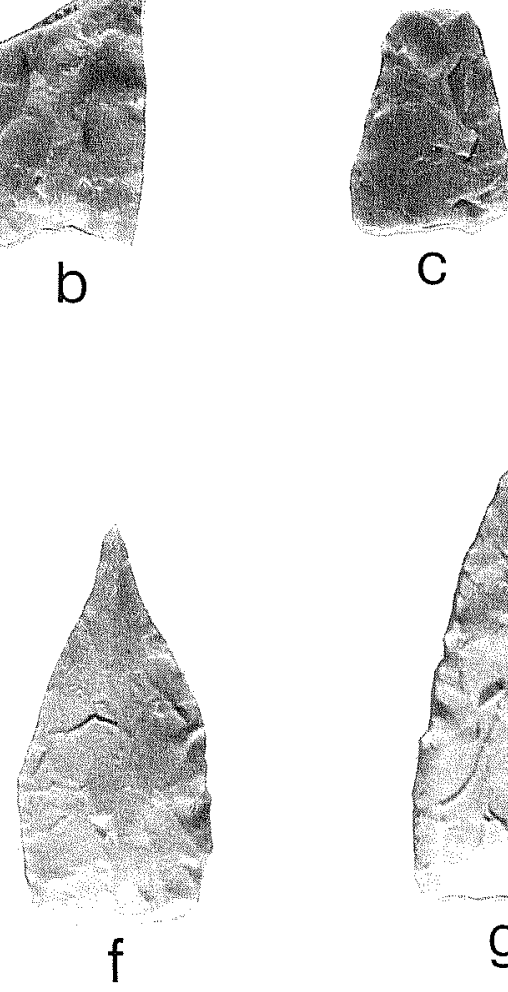

C
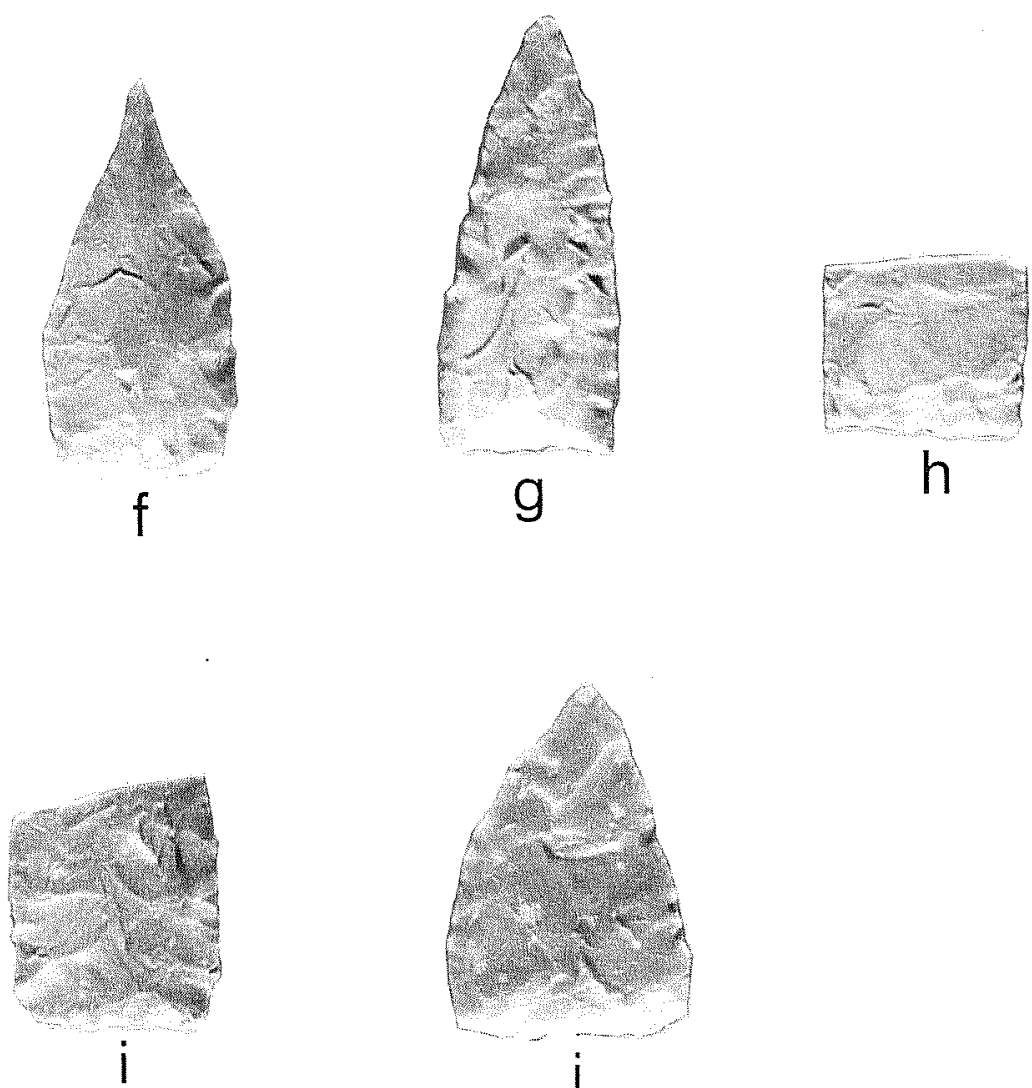

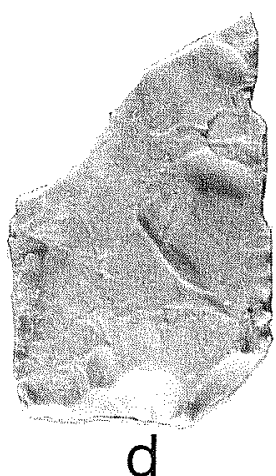

$\mathrm{h}$

Figure 22. Thin Bifaces with Concave and Straight Bases from 41 BX 1. Thin bifaces with concave bases: a, Specimen 1; b, Specimen 2; c, Specimen 3; d, Specimen 4; e, Specimen 5. Thin bifaces with straight bases: f, Specimen 1; g, Specimen 2; h, Specimen 3; i, Specimen 4; j, Specimen 5. 
SPECIMEN 3 (Fig. 22,h). Incomplete specimen with parallel straight blades. Material is a very pale brown chert. Dimensions: ML: (3.3), MW: 3.5, MT: 0.7, WT: 8.9. Provenience: E1013 N1001, 98.40-98.30.

SPECIMEN 4 (Fig. 22,i). Incomplete specimen with parallel straight blades. Material is a gray chert. Dimensions: ML: (4.3), MW: 3.6, MT: 0.8, WT: 15.0. Provenience: E1014 N1002, 98.70-98.60.

SPECIMEN 5 (Fig. 22,j). Convex and irregular blades form a roughly triangular outline. Irregular edge exhibits step and hinge fractures. Material is a gray chert. Dimensions: ML: 6.2, MW: 4.3, MT: 0.9, WT: 21.5. Provenience: E1014 N1002, 98.60-98.50.

\section{Concave Base}

Specimen 1 appears to be a finished form, but the other four are incomplete. Specimens 1 and 2 are very similar in form, and together with Specimen 5, could be considered preforms. All five specimens are decorticate.

SPECIMEN 1 (Fig. 22,a). Straight blades form a triangular outline. The specimen is a burned, very dark gray chert. Dimensions: ML: (4.6), MW: 2.8, MT: 0.8, WT: 10.0. Provenience: E1010 N1000, 98.50-98.40.

SPECIMEN 2 (Fig. 22,b). Slightly convex blades form a roughly lanceolate outline. Material is a gray chert. Dimensions: ML: (4.7), MW: 2.8, MT: 0.9, WT: 10.0. Provenience: E1012 N1002, 98.10-98.00.

SPECIMEN 3 (Fig. 22,c). Convex and irregular blades. Basal concavity forms a wide notch with a steep bevel on one face. Material is a very pale brown chert. Dimensions: ML: (3.7), MW: 4.3, MT: 1.1, WT: 22.5. Provenience: E1010 N1000, 98.70-98.60.

SPECIMEN 4 (Fig. 22,d). Straight and irregular blades. An overshot flake scar towards the distal end resulted in the breakage of the specimen. Dimensions: ML: (7.1), MW: 4.5, MT: 0.7, WT: 35.0. Provenience: E1012 N1002, 98.80-98.70.

SPECIMEN 5 (Fig. 22,e). Irregular blades. The specimen is roughly triangular in outline and could be considered a small preform. Material is a reddish brown chert. Dimensions: ML: (3.8), MW: 2.8, MT: 0.7, WT: 7.1. Provenience: E1029 N1001, 99.10-99.00.

\section{Pointed Biface Fragments}

A total of 26 thin, pointed biface fragments was recovered. They taper to a pointed end and appear to be the distal ends of bifaces. Although the degree of "finish" varies, undoubtedly some of the specimens are dart point tips. One-half of the specimens have convex blade edges (13 specimens). Six specimens have straight blade edges, and one of these is serrated. Of the remaining fragments, three have one convex and one straight side, one is recurved, and three are too small or irregular to define the edge shape. Only one specimen is burned. Most of the chert is light to dark gray, but approximately one-third of the specimens are reddish brown to brown. Dimensions: ML: (9.9)-(2.2), MW: 5.3-1.6, MT: 1.4-0.4. Provenience: E1010 N1000, 98.60-98.50; E1010 N1000, 98.40-98.30; E1010 N1000, 98.10-98.00; E1011 N999, 98.60-98.50; E1012 N997, 98.22-98.10; E1012 N998, 98.40-98.30; E1012 N1002, 98.50-98.40 (2); E1012 N1002, 98.40-98.30; E1012 N1002, 98.00-97.90; E1012 N1002, 97.80-97.70; E1013 N1000, 98.30-98.20; E1013 N1001, 98.60-98.50; E1014 N999, 98.25-98.10; E1014 N1001, 98.50-98.40; E1014 N1002, 98.40-98.30 (2); E1014 N1002, 98.30-98.20; E1022 N1065, 99.30-99.20; E1022 N1065, 99.10-99.00; E1029 N1001, 99.10-99.00; E1029 N1001, 97.60-97.50; Burial 2; Trench 18 (Zone 3); Area A surface; general surface collection. 
Two Sides

Six thin bifaces with two worked sides are midsections and are wider at one end. It is presumed they tapered towards a point. Edge forms are convex, straight, and irregular. They vary from gray to grayish brown. Two specimens are burned. Dimensions: ML: (3.7)-(1.4), MW: (5.0)-(1.3), MT: 0.9-0.4. Provenience: E1010 N1000, 98.30-98.20; E1012 N1002, 98.60-98.50; E1012 N1002, 98.30-98.20; E1013 N1001, 98.90-98.80; E1014 N1001, 98.40-98.30; E1029 N1001, 98.40-98.30.

\section{One Edge}

Thirteen specimens are lateral or basal fragments of bifaces that have only one worked edge. Nine of the fragments have convex edges, and three have straight edges. The remaining fragment has a sinuous, irregular edge. None of the fragments are burned. One specimen is brown, one pinkish brown, and the remaining fragments vary from brownish gray to gray. The measurements represent the distance measured from end to end of the bifacially worked edge of the fragment. Dimensions: ML: (5.3)-(1.0). Provenience: E1010 N1000, 98.60-98.50; E1010 N1000, 98.50-98.40; E1010 N1000, 98.40-98.30; E1012 N998, 98.30-98.20; E1012 N1000, 98.60-98.50; E1012 N1002, 98.60-98.50; E1012 N1002, 98.40-98.30; E1014 N999, 98.25-98.10; E1014 N1002, 98.50-98.40; E1022 N1065, 98.90-98.80 (2); E1029 N1001, 99.20-99.10; E1029 N1001, 99.10-99.00.

\section{Miscellaneous Fragments}

Miscellaneous thin biface fragments (11 specimens) have two or more edges worked, but because of their nongeometrical shape could not be placed within any of the preceding categories. Two fragments are burned. Seven specimens vary in color from dark gray to grayish brown. Four fragments are brown to reddish brown. Dimensions: ML: 8.7-2.4, MT: 1.4-0.5. Provenience: E1010 N1000, 98.70-98.60; E1010 N1000, 98.50-98.40; E1012 N1002, 97.80-97.70; E1012 N1002, 97.70-97.60; E1014 N1002, 98.30-98.20; E1022 N1065, 98.50-98.40; E1029 N1001, 99.30-99.20; E1029 N1001, 99.20-99.10; E1029 N1001, 99.10-99.00; F. S. Burial; general surface collection.

\section{$\underline{\text { Distally Beveled Bifaces }}$}

The distally beveled biface category refers to specimens often called gouges. They have steeply beveled distal ends, or a distinctive "bit" on the working face, which distinguishes them from other categories of bifaces. All three specimens recovered are decorticate.

\section{Specimen 1}

Specimen 1 (Fig. 23,c) is subtriangular in outline and roughly plano-convex in cross section. This type of artifact is sometimes referred to as a Clear Fork gouge. Material is a very pale brown chert. Dimensions: ML: 6.5, MW: 4.6, MT: 1.1, WT: 36.6. Provenience: E1022 N1065, 99.20-99.10.

\section{Specimen 2}

Specimen 2 (Fig. 23,a) is a typical Guadalupe tool. It is roughly triangular in cross section and exhibits an oblique bit formed by the removal of a single flake struck from the medial ridge of the specimen. Material is a dark grayish brown chert. Dimensions: ML: 11.1, MW: 3.0, MT: 2.3, WT: 95.9. Provenience: general surface collection. 

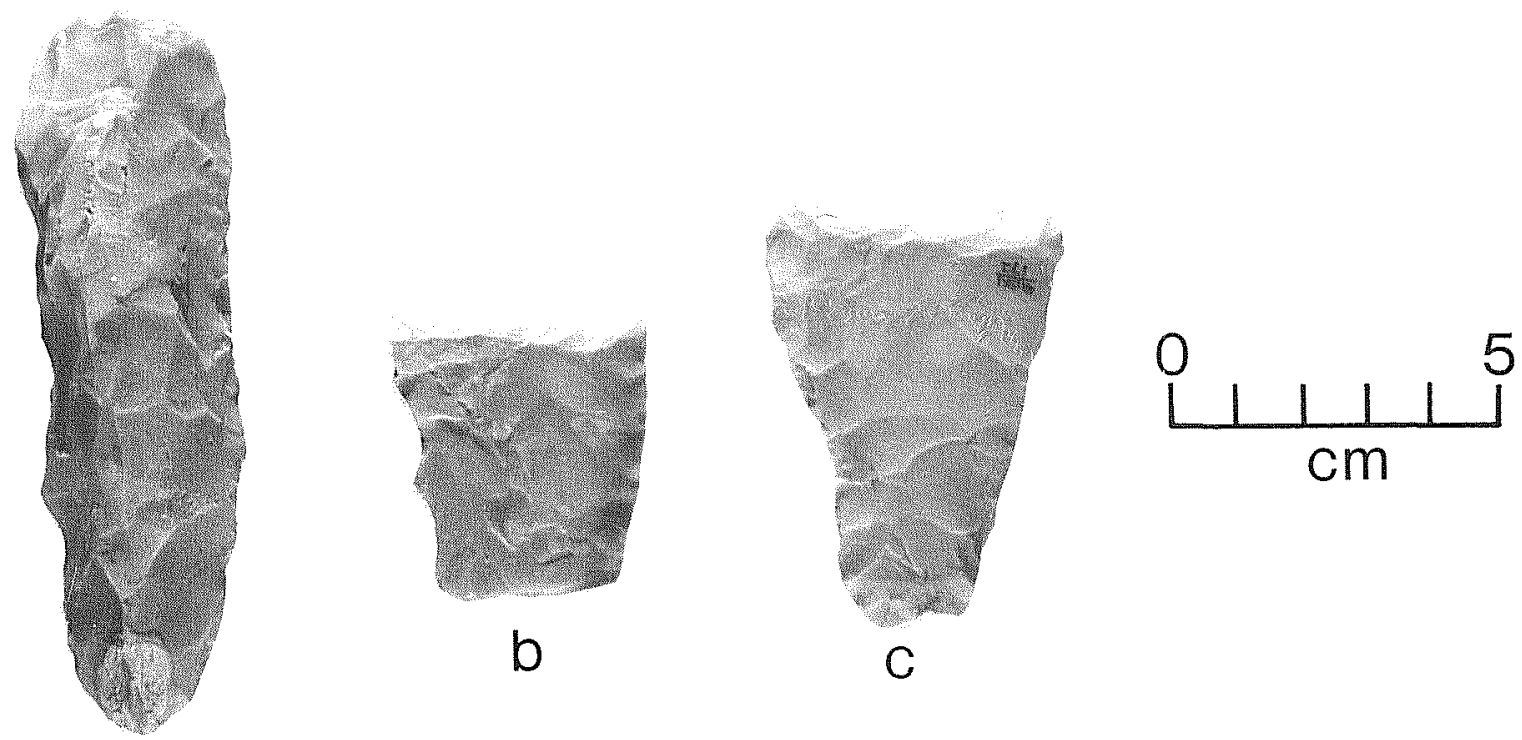

a
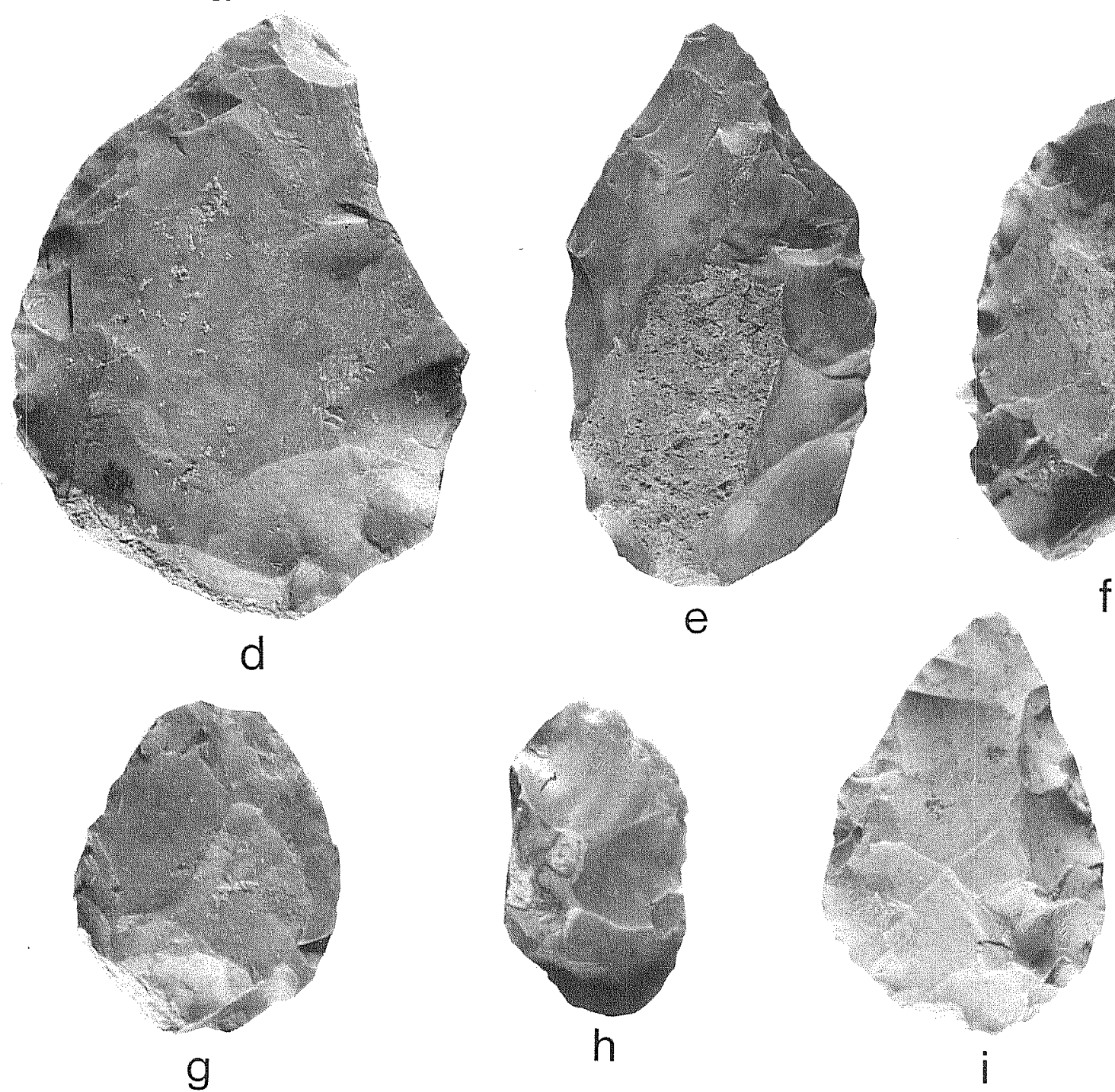

Figure 23. Distally Beveled Bifaces and Thick Bifaces with a Convex Base and Convex Sides from 41 BX1. Distally beveled bifaces: a, Specimen 2; b, Specimen 3; c, Specimen 1 . Thick bifaces with a convex base and convex sides: d, Specimen 1 ; e, Specimen 2; f, Specimen 7; g, Specimen 3; h, Specimen 4; i, Specimen 5. 
Specimen 3

Trapezoidal outline and biconvex in cross section, Specimen 3 (Fig. 23,b) was probably made utilizing the midsection of a biface. The distally beveled straight working edge is located at the broadest end of the specimen. Material is a very pale brown chert. Dimensions: ML: 4.4, MW: 4.0, MT: 0.8, WT: 17.8 . Provenience: E1011 N999, 98.40-98.30.

\section{Thick Bifaces}

Nineteen specimens are classified as thick bifaces and are $1.5 \mathrm{~cm}$ or more in maximum thickness. Generally, they are roughly shaped cobbles with 10 or more negative flake scars. Some of the specimens may be cores or core tools (such as choppers). The specimens are divided into four categories: convex base with convex sides, straight bases, convex edges, and thick biface fragments.

\section{Convex Base with Convex Sides}

Eight thick biface specimens have a convex base with convex sides. They are roughly shaped with ovate to pointed ovate outlines. Specimens 1 and 2 retain cortex on one of their broadest ends. Only one specimen is decorticate. Each specimen is individually described.

SPECIMEN 1 (Fig. 23,d). Broad-pointed ovate outline with cortex on one face. Material is pinkish gray chert. Dimensions: ML: 11.8, MW: 9.0, MT: 2.6, WT: 309.5. Provenience: E1014 N1002, 98.50-98.40.

SPECIMEN 2 (Fig. 23,e). Roughly a pointed ovate outline form with cortex on both faces. Material is a gray chert. Dimensions: ML: 11.3, MW: 6.0, MT: 3.4, WT: 215.3. Provenience: E1014 N1002, 98.20-98.10.

SPECIMEN 3 (Fig. 23,g). Rough ovate outline form with cortex remaining on one face. Material is a light brown chert. Dimensions: ML: 6.7, MW: 5.4, MT: 1.8, WT: 69.8. Provenience: E1011 N999, 98.50-98.40.

SPECIMEN 4 (Fig. 23,h). Rough ovate outline form with cortex remaining on one face. Material is a light brown chert. Dimensions: ML: 6.4, MW: 3.8, MT: 1.5, WT: 42.3. Provenience: E1012 N1002, 98.50-98.40.

SPECIMEN 5 (Fig. 23,i). Pointed ovate outline. Specimen is made on a decorticate flake of very pale brown chert. Dimensions: ML: 8.5, MW: 6.0, MT: 1.7, WT: 75.7. Provenience: E1014 N1002, 98.50-98.40.

SPECIMEN 6. Ovate outline with an unusually thick plano-convex cross section. Cortex remains on one face of the specimen. Material is a very pale brown chert. Dimensions: ML: 13.0, MW: 8.8, MT: 4.5, WT: 491.2. Provenience: Area A surface.

SPECIMEN 7 (Fig. 23,f). Ovate outline with cortex remaining on both faces. Very pale brown color. Dimensions: ML: 9.5, MW: 6.1, MT: 2.3, WT: 127.2. Provenience: Zone 2 of Area B.

SPECIMEN 8. Narrow ovate outline with cortex remaining on one face. Specimen is reminiscent of a Guadalupe tool, but the form is much rougher. Material is a pinkish gray chert. Dimensions: ML: 10.3, MW: 5.4, MT: 2.6, WT: 123.7. Provenience: E1010 N1000, 98.10-98.00.

\section{Straight Base}

Specimens 1 and 2 have roughly triangular outlines, and Specimen 3 is roughly rectangular in outline. Two specimens are decorticate. 
SPECIMEN 1 (Fig. 24,b). Roughly shaped cobble with one convex side and one irregular side. Cortex remains on both faces and some of the edges. Material is a brownish gray chert. Dimensions: ML: 8.5 , MW: 5.4 , MT: 1.7, WT: 90.0. Provenience: E1010 N1000, 98.40-98.30.

SPECIMEN 2 (Fig. 24,c). Roughly shaped with one convex and one straight side. Material is brownish gray decorticate chert. Dimensions: ML: 8.8, MW: 5.3, MT: 1.7, WT: 85.6. Provenience: E1013 N999, 98.30-98.20.

SPECIMEN 3 (Fig. 24,a). Edges are both straight to irregular, giving the specimen a roughly rectangular outline. Material is a pale brown decorticate chert. Dimensions: ML: 11.9, MW: 7.8, MT: 3.9, WT: 309.1. Provenience: Trench 21, backdirt.

\section{Convex Edges}

Two thick biface specimens with convex edges are small, roughly circular with a strong lenticular cross section.

SPECIMEN 1 (Fig. 24,e). Material is a dark brownish gray chert with cortex remaining on one surface. Dimensions: ML: 6.4, MW: 6.2, MT: 2.6, WT: 77.7. Provenience: general surface collection.

SPECIMEN 2 (Fig. 24,d). Material is a dark brownish gray chert with cortex remaining on one surface. Dimensions: ML: 6.3, MW: 5.8, MT: 3.2, WT: 87.8. Provenience: E1022 N1065, 99.40-99.30.

\section{Thick Biface Fragments}

Various fragments of thick bifaces are represented by four ends, one midsection, and one lateral edge. One specimen is apparently a proximal fragment with a convex base and convex side; the others are too small or irregular to classify. Three specimens are decorticate. Four specimens are shown in Figure 24,f-i. Dimensions: ML: 8.1-4.5, MW: 7.5-3.0, MT: 2.7-1.7, WT: 127.5-23.8. Provenience: E1012 N999, 98.20-98.10; E1012 N1002, 98.20-98.10; E1022 N1065, 99.30-99.20; E1029 N1001, 99.20-99.10; E1029 N1001, 99.00-98.90 (2).

\section{Retouched Flakes}

Retouched flakes (54 specimens) have been marginally altered after removal from the parent source. Categories are based primarily on the edge form (convex, concave, and straight) and the placement of retouch (sides, end, etc.). The faces worked and flake type(s) are noted in the short descriptions for each category. For this report, the approximate size of retouch flake scars is divided into large $(+3 \mathrm{~mm})$ and small $(1-3 \mathrm{~mm})$. Distinctions were based on visual inspection, or edges were compared to preset calipers. Specimens with flake scars deemed less than $1 \mathrm{~mm}$ were placed into the modified flake category.

Overall, 57\% (31 of 54) of the flakes are worked on one edge (side or end) only. Twenty-six percent (14 of 54) are worked on two sides; $11 \%$ are bifacially worked (6 of 54); and 6\% are worked on three sides ( 3 of 54). Sixty-three percent of the flakes are secondary flakes; $37 \%$ are interior. The percentage of the specimens with retouch is as follows: $56 \%$, small retouch $35 \%$, combinations of large and small retouch $2 \%$, unrecorded flake scar size $7 \%$.

Retouch scars were on the dorsal surface of the flake in $56 \%$ of the specimens; on the ventral face in $18 \%$ of the specimens; and in $26 \%$ of the specimens, retouch was on both faces (although only approximately half of these specimens are bifacially worked). 

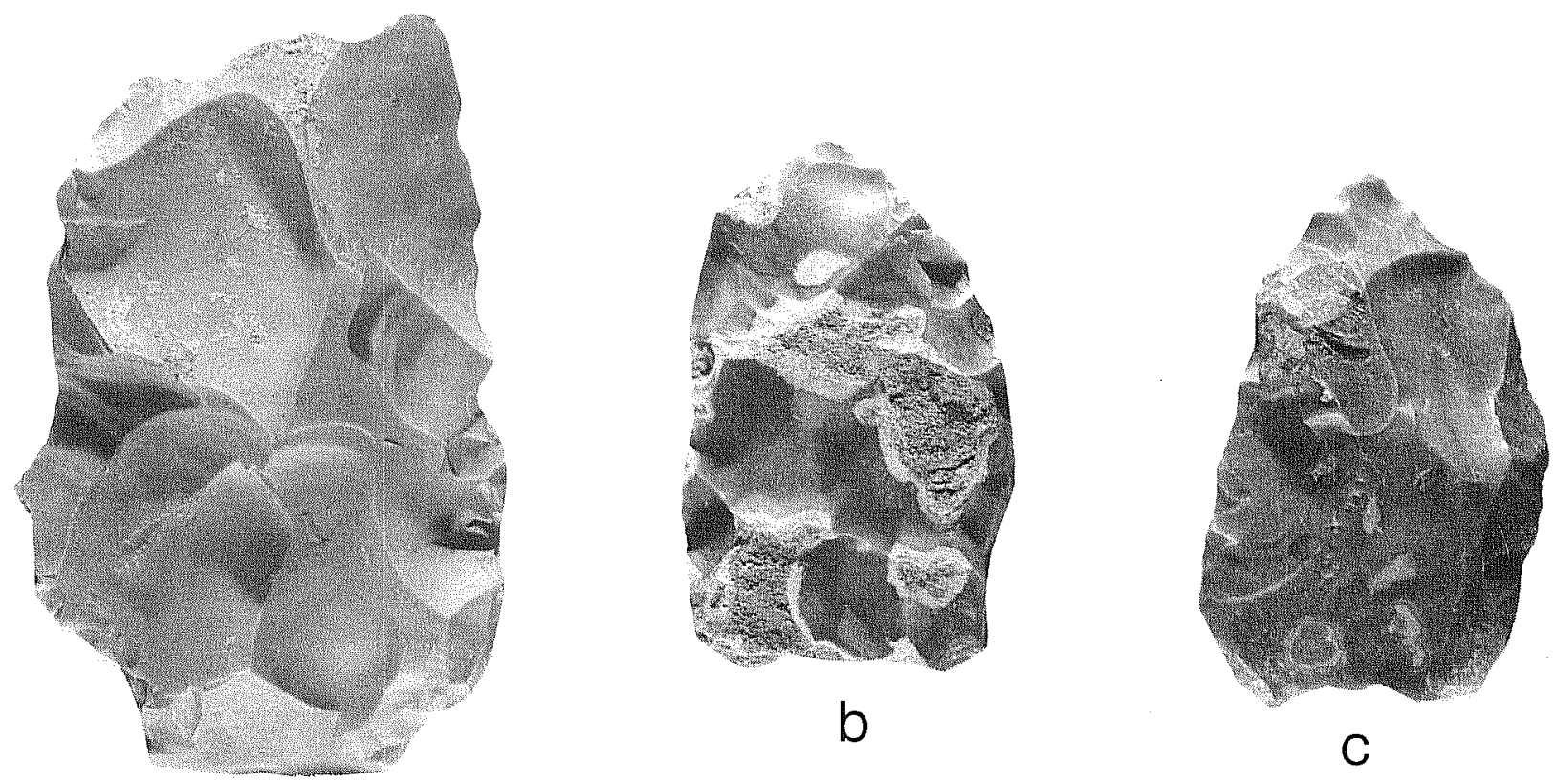

a

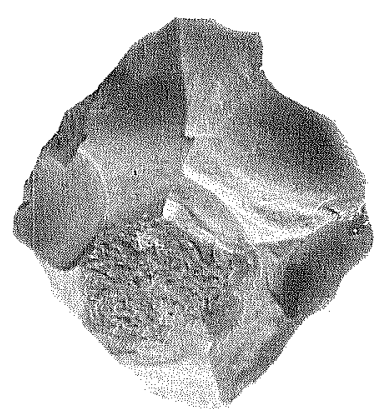

d

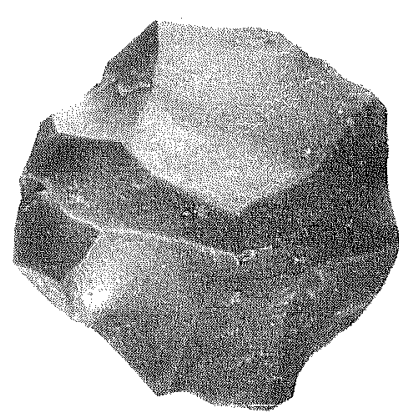

e

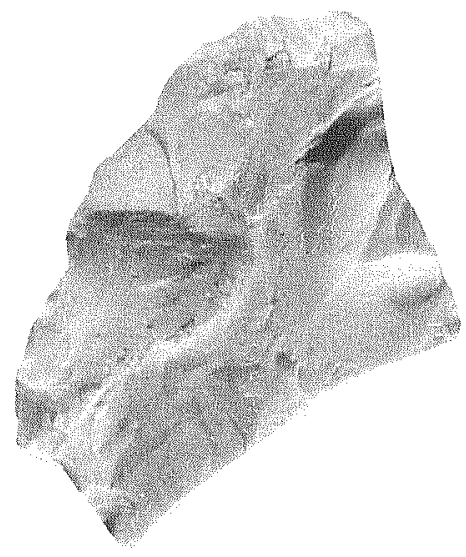

f

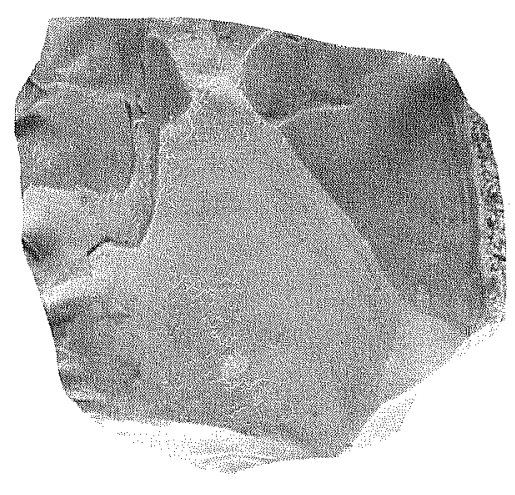

g

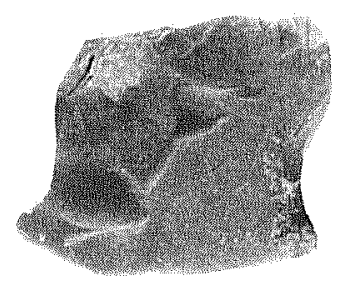

h

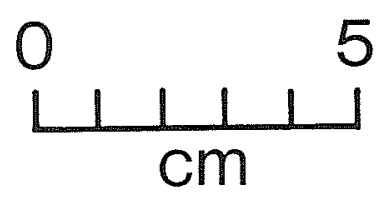

Figure 24. Thick Bifaces with a Straight Base, Thick Bifaces with Convex Edges, and Thick Biface Fragments from 41 BX 1 . Thick bifaces with a straight base: a, Specimen 3; b, Specimen 1; c, Specimen 2. Thick bifaces with convex edges: d, Specimen 2; e, Specimen 1; $\mathrm{f}-\mathrm{i}$, thick biface fragments. 
Finally, a total of 74 individual edges was worked. Edge forms (and their relative percentage within this group) include: convex edges $28 \%$, irregular edges $28 \%$, straight $19 \%$, concave $15 \%$, unknown or indeterminate $10 \%$.

\section{One Side Retouched}

Twenty-three specimens are retouched along one lateral edge and are unifacial. Within this category $65 \%$ are secondary flakes, and $35 \%$ are interior flakes. Sixty-one percent have large retouch scars; $39 \%$ have small retouch scars. Seventy-four percent are retouched on the dorsal face; $26 \%$ are retouched on the ventral face. Edge forms listed in order of relative percentages are: irregular edges $40 \%$, convex edges $26 \%$, straight edges $17 \%$, concave edges $13 \%$, and indeterminate edges $4 \%$.

ONE SIDE, IRREGULAR EDGES. Seven secondary flakes and two interior flakes have irregular edges. Retouch is large on all but the two interior flakes. Retouch is on the dorsal face of five of the flakes, and four flakes are retouched on the ventral face. Two specimens are shown in Figure 25,a,b. Dimensions: ML: 10.1-4.2, MW: 7.8-3.9, MT: 3.7-0.5. Provenience: E1012 N1002, 98.50-98.40; E1012 N1002, 98.40-98.30 (2); E1012 N1002, 98.10-98.00; E1012 N1002, 97.80-97.70; E1013 N1001, 98.50-98.40; E1022 N1065, 99.20-99.10; E1029 N1001, 99.30-99.20; E1029 N1001, 98.00-97.90.

ONE SIDE, CONVEX EDGES. Three secondary and three interior flakes have convex edges. Only one specimen has large retouch scars; the others have small retouch scars. All but one specimen is retouched on the dorsal face. Three specimens are shown in Figure 25,c-e. Dimensions: ML: 12.2-2.5, MW: 6.8-1.6, MT: 2.8-0.4. Provenience: E1010 N1000, 98.60-98.50; E1014 N1000, 98.40-98.30; E1012 N1002, 98.20-98.10; E1014 N1001, 98.30-98.20 (2); E1022 N1065, 99.50-99.40.

ONE SIDE, STRAIGHT EDGES. Two interior flakes and two secondary flakes have straight edges. The secondary flakes have large retouch scars; the interior flakes have small retouch scars. One of the interior flakes is worked on the ventral face and is burned. The others are worked on the dorsal face. One specimen is shown in Figure 25,f. Dimensions: ML: 10.3-2.7, MW: 7.5-2.4, MT: 2.6-0.3. Provenience: E1012 N1002, 98.70-98.60; E1012 N1002, 98.10-98.00; E1014 N1002, 98.80-98.70; general surface collection.

ONE SIDE, CONCAVE EDGES. Two secondary flakes and one interior flake with concave edges are worked on the dorsal face and have large retouch scars. One specimen is shown in Figure 25,g. Dimensions: ML: 7.9-5.0, MW: 5.2-3.1, MT: have 1.7-0.7. Provenience: E1012 N1002, 98.30-98.20, E1002 N1002, 97.80-97.70; Feature 7.

ONE SIDE, INDETERMINATE EDGES. A secondary flake with indeterminate edges has large retouch scars on the dorsal face. Dimensions: ML: 4.0, MW: 3.6, MT: 1.9. Provenience: E1010 N1000, 98.30-98.20.

\section{Two Sides Retouched}

Ten flakes with retouch along both lateral sides, are all unifacial. In this category $60 \%$ are secondary flakes, and $40 \%$ are interior flakes. Twenty percent have large retouch scars, $30 \%$ have only small flake scars, $10 \%$ have combinations of large and small flake scars, and $40 \%$ are of unrecorded size. Sixty percent are worked on both the dorsal and ventral faces, $30 \%$ are worked on the dorsal face, and $10 \%$ are worked on the ventral face. The relative percentage of individual edge forms (20 edges or $2 \times 10$ specimens) is: irregular $40 \%$, concave edges $30 \%$, straight edges $25 \%$, convex edges $5 \%$.

TWO SIDES, IRREGULAR EDGES. A total of four retouched flake specimens with irregular edges was recovered. The two larger specimens are secondary flakes apparently randomly struck on either the dorsal or ventral side of each specimen. The two smaller interior flakes are blades with uneven lateral edges alternately flaked on the dorsal face of one lateral edge and on the ventral face of the alternate edge. One 


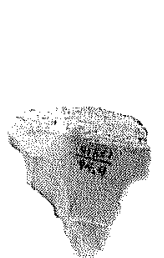

a

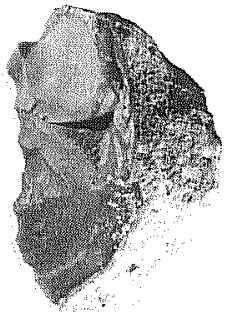

b

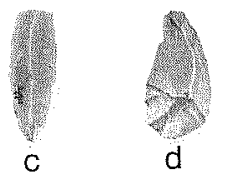

C

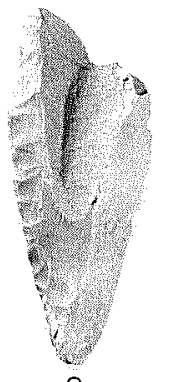

e

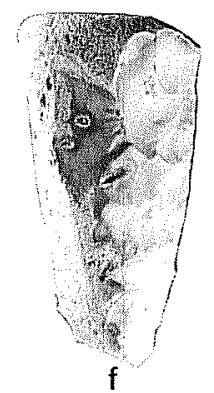

f

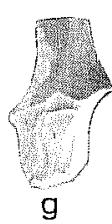

$\mathrm{g}$
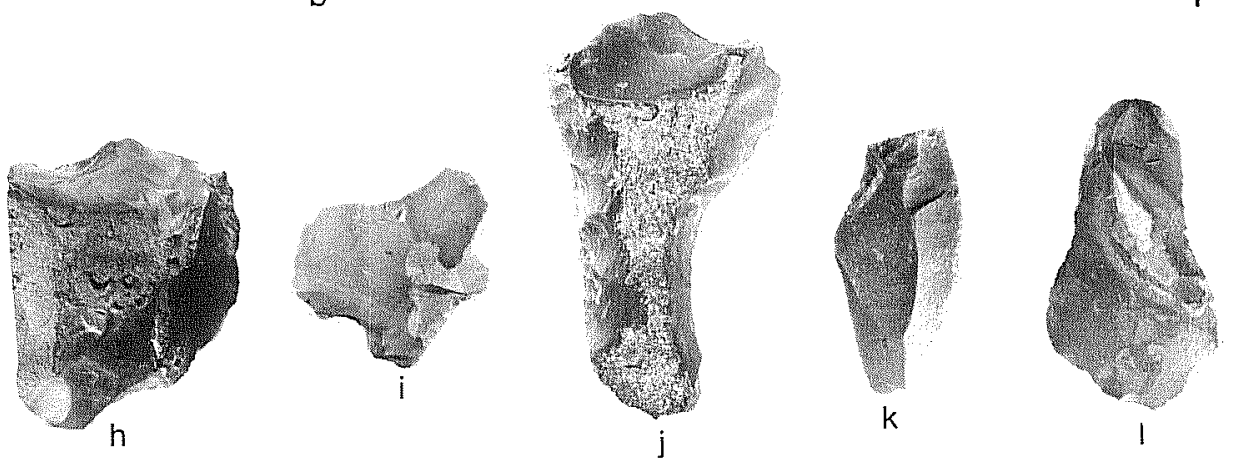

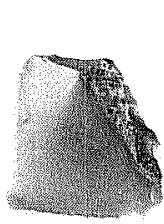

$\mathrm{m}$

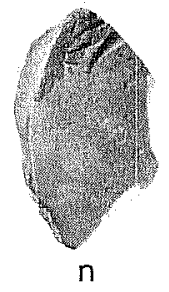

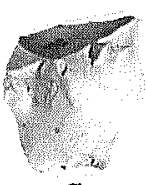

q

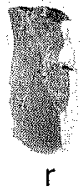

$r$ $p$
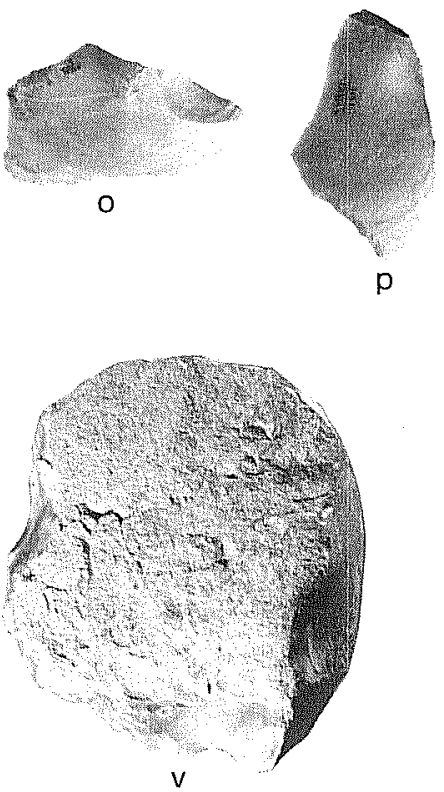

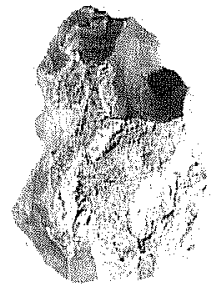

5

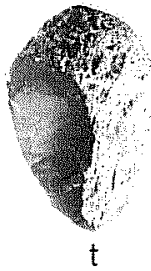

$t$

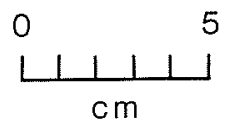

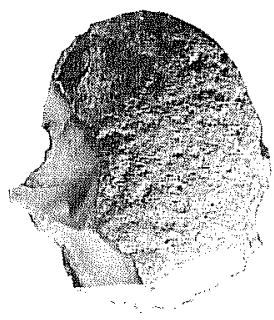

U

Figure 25. Retouched Flakes from 41 BX 1. One side retouched: a,b, irregular edges; c-e, convex edges; $\mathrm{f}$, straight edges; $\mathrm{g}$, concave edges. Two sides retouched: $h$, irregular edges; $i, j$, straight and concave edges; $k$, convex and straight edges; 1 , concave edges; $\mathrm{m}$, straight edges. One end retouched: $\mathrm{n}$, straight edges; o, concave edges; $p$, straight edges; $q$, irreqular edges; r, convex end. One end and one side retouched: $s$, end convex and sides irregular; $t$, end and sides convex. One end and two sides retouched: $u$, convex edges; $v$, two sides straight, one end convex; w, bifacial retouched edges. 
specimen is shown in Figure 25,h. Dimensions: ML: 7.8-4.5, MW: 7.8-1.5, MT: 3.3-0.4. Provenience: E1010 N1000, 98.70-98.60; E1012 N1001, 98.60-98.50; E1022 N1065, 99.40-99.30; E1029 N1001, 98.60-98.50.

TWO SIDES, CONCAVE AND STRAIGHT EDGES. One specimen is on an interior flake, and the other is a secondary flake. Both have large retouch on the dorsal face. The specimen shown in Figure 25,j is similar to Weir's (1976a:70, Fig. 25) strangulated uniface. The other specimen (Fig. 25,i) is typically called a notched flake. Dimensions: ML: 11.3-4.8, MW: 6.7-4.7, MT: 2.5-1.7. Provenience: E1014 N1002, 98.50-98.40; Area A surface.

TWO SIDES, CONVEX AND STRAIGHT EDGES. An interior flake (Fig. 25,k) with small retouch scars has the straight edge formed on the ventral face and the convex edge on the dorsal face. Dimensions: ML: 6.4, MW: 3.1, MT: 0.7. Provenience: E1013 N1001, 98.30-98.20.

TWO SIDES, CONCAVE EDGES. One specimen is an interior flake with small retouch scars located on the dorsal face on one side and on the ventral face of the other side. The other specimen is a secondary flake retouched on the dorsal face only. On one side, edge retouch scars are small and are large on the other side. One specimen is shown in Figure 25,1. Dimensions: ML: 8.9-5.8, MW: 5.2-4.5, MT: 1.1-0.9. Provenience: E1010 N1000, 98.60-98.50; E1010 N1000, 98.40-98.30.

TWO SIDES, STRAIGHT EDGES. This interior flake has small retouch scars on the ventral face (Fig. 25,m). Dimensions: ML: 4.9, MW: 4.1, MT: 1.3. Provenience: E1029 N1001, 98.70-98.60.

\section{One End Retouched}

Eight flakes have retouch scars on the distal end of the specimen, and all are unifacial. The percentage of interior and secondary flakes is $50 \%$ for each flake type. Eighty-eight percent of the flakes have only small retouch scars; $13 \%$ (a single specimen) have large retouch scars. Sixty-three percent have retouch scars on the dorsal face, and $38 \%$ have retouch scars only on the ventral face. Edge forms and their percentage within this category are: straight $38 \%$, concave $25 \%$, irregular $25 \%$, and convex $13 \%$.

ONE END, STRAIGHT EDGE. Two interior flakes and one secondary flake have retouch scars on one end and a straight edge. All have small retouch scars on the dorsal face. Two specimens are shown in Figure 25,n,p. Dimensions: ML: 5.8-2.2, MW: 3.2-1.9, MT: 1.1-0.2. Provenience: E1022 N1065, 99.50-99.40; E1022 N1065, 98.90-98.80; E1029 N1001, 98.90-98.80.

ONEEND, CONCAVE EDGE. Both specimens are secondary flakes with small retouch scars on the ventral face. One specimen is shown in Figure 25,o. Dimensions: ML: 7.0-5.8, MW: 4.2-3.8, MT: 2.0-1.2. Provenience: E1022 N1065, 99.50-99.40; E1029 N1001, 98.20-98.10.

ONE END, IRREGULAR EDGES. One specimen is an interior flake with large retouch scars on the ventral face. The other specimen is a secondary flake with small retouch scars on the dorsal face. One specimen is shown in Figure 25,q. Dimensions: ML: 4.7-4.4, MW: 4.2-3.6, MT: 2.0-0.8. Provenience: E1012 N1002, 98.4098.30; E1012 N1002, 98.20-98.10.

ONE END, CONVEX EDGE. This specimen is an interior flake with small retouch scars on the dorsal face (Fig. 25,r). Dimensions: ML: 4.5, MW: 1.8, MT: 0.6. Provenience: E1022 N1065, 99.50-99.40.

\section{One End and One Side Retouched}

Four flakes are unifacially worked along one lateral side and the distal end. Three specimens (75\%) are secondary flakes; one (25\%) is an interior flake. Retouch flake scars are all classified as large. Half of the specimens (two) are worked on the dorsal side, and half are worked on both the dorsal and ventral sides. Edge forms are convex ( $75 \%$ or six individual edges) and irregular (25\% or two individual edges). 
END CONVEX, SIDES IRREGULAR. Both specimens have large retouch scars on the end of the ventral face and the side of the dorsal face. One specimen is an interior flake; the other is a secondary flake. One specimen is shown in Figure 25,s. Dimensions: ML: 7.5-6.5, MW: 5.5-5.3, MT: 2.0-1.8. Provenience: E1010 N1000, 98.10-98.00 (2).

END CONVEX, SIDES CONVEX. Both specimens are secondary flakes with large retouch scars on the dorsal surface. One specimen is shown in Figure 25,t. Dimensions: ML: 8.2-6.1, MW: 7.4-4.2, MT: 2.4-2.0. Provenience: E1013 N1001, 98.80-98.70; E1022 N1065, 99.30-99.20.

\section{One End and Two Sides Retouched}

Three flakes are retouched along both lateral margins, and the distal end of each is unifacial. All are secondary flakes, have large retouch flake scars, and are worked on the dorsal face of the flake. Of the nine individual edge forms, $78 \%$ are classified as convex, and $22 \%$ (or two individual edges) are straight.

ONE END AND TWO SIDES, CONVEX EDGES. Both specimens are secondary flakes with large retouch scars on the dorsal face. One specimen is shown in Figure 25,u. Dimensions: ML: 7.9-6.5, MW: 7.0-6.1, MT: 2.7-2.3. Provenience: Area A surface; E1014 N998, 98.20-98.10.

ONE END CONVEX, TWO SIDES STRAIGHT. A secondary flake has large retouch scars on the dorsal face (Fig. 25,v). Dimensions: ML: 8.3, MW: 7.6, MT: 2.4. Provenience: general surface collection.

\section{Bifacial Retouched Edges}

Of the six specimens with bifacial retouched edges, five are secondary flakes, and five have convex or roughly convex edges. Three specimens have a retouched edge on one side only, and the remaining specimens have more than one edge retouched. One specimen is shown in Figure 25,w. Dimensions: ML: 10.8-5.3, MW: 10.1-3.7, MT: 3.7-1.1. Provenience: E1010 N1000, 98.60-98.50; E1010 N1000, 98.10-98.00; E1012 N1002, 98.30-98.20; E1013 N1000, 98.50-98.40; E1022 N1065, 99.30-99.20; E1022 N1065, 99.10-99.00.

\section{Retouched Chips}

The categories of retouched chips are based primarily on retouch placement and are divided by edge forms. All 28 specimens are unifacially worked unless otherwise noted and are made of chert. Morphological distinctions between large and small retouch is the same as for the retouched flakes.

Seventy-five percent of the chips (21 of 28) are worked on one edge only. Five are worked on two edges, and three are worked on three edges. Fifty percent $(14$ of 28$)$ of the chips are decorticate. Sixty-four percent of the chips ( 18 of 28 ) have large retouch scars; $36 \%$ (10 of 28$)$ have small retouch scars. Thirty-seven individual edges were counted within this category, and the edge form types are as follows: irregular edges represent $40 \%$ (15 of 37), convex edges represent $22 \%$ ( 8 of 37), indeterminate and convergent edges represent $16 \%$ ( 6 of 37), straight edges represent $13 \%$ (5 of 37), and concave edges represent $8 \%$ ( 3 of 37 ).

\section{One Side}

Twenty-one retouched chips are unifacial and have retouch along one edge. Overall, 10 specimens (48\%) are partially corticate, and 11 specimens $(52 \%)$ are decorticate. Sixteen of the chips (76\%) exhibit large retouch scars, and five have small retouch scars (24\%). Of the 21 individually retouched edges, the edge forms and the percentage of each are as follows: convex $33 \%$, straight $24 \%$, irregular $19 \%$, concave $14 \%$, and convergent $10 \%$. 
ONE SIDE, CONVEX EDGES. Three specimens are partially corticate, and four specimens are decorticate chips. All have large retouch scars. One specimen is shown in Figure 26,a. Dimensions: ML: 8.9-1.6, MW: 7.1-1.3, MT: 2.5-0.3. Provenience: E1012 N1002, 98.60-98.50; E1014 N1000, 98.61-98.40; E1022 N1065, 99.50-99.40; E1022 N1065, 99.30-99.20; E1022 N1065, 99.20-99.10; E1029 N1001, 99.00-98.90 (2).

ONE SIDE, STRAIGHT EDGES. Four specimens are decorticate, and one specimen is partially corticate. The single partially corticate chip has large retouch flake scars; the other specimens have small retouch scars. One specimen is shown in Figure 26,b. Dimensions: ML: 5.5-3.5, MW: 3.6-2.8, MT: 2.1-0.5. Provenience: E1013 N1001, 98.80-98.70; E1022 N1065, 99.50-99.40 (2); E1022 N1065, 98.90-98.80; Area A surface.

ONE SIDE, IRREGULAR EDGES. Two decorticate and two partially corticate chips have large retouch scars. One specimen is shown in Figure 26,c. Dimensions: ML: 6.6-4.5, MW: 4.3-2.2, MT: 1.5-1.4. Provenience: E1012 N1002, 98.40-98.30; E1015 N999, 98.40-98.20; E1022 N1065, 99.30-99.20; Burial 8.

ONE SIDE, CONCAVE EDGES. Three specimens are partially corticate chips. One specimen has a small notch $0.7 \mathrm{~cm}$ wide; the other two specimens have broader $(2.0-2.5 \mathrm{~cm})$, shallower worked edges. One specimen is shown in Figure 26,d. Dimensions: ML: 6.2-3.7, MW: 5.2-3.2, MT: 2.1-1.3. Provenience: E1012 N1002, 98.30-98.20; E1012 N1002, 98.20-98.10; E1029 N1001, 99.00-98.90.

ONE SIDE, CONVERGENT EDGES. The two specimens have two recognizable edge forms along one side of the artifact. One specimen is a decorticate chip with small retouch. On it, two straight edges on the dorsal face meet to form a broadly expanding beak. The second specimen is a partially decorticate chip with large retouch scars, and irregular and concave edge forms. Both edge forms are unifacial and are made on one lateral side, but on alternating faces of the chip. One specimen is shown in Figure 26,e. Dimensions: ML: 5.8-4.3, MW: 4.3-2.5, MT: 2.1-0.4. Provenience: E1022 N1065, 99.40-99.30; E1022 N1065, 98.90-98.80.

\section{Two Sides}

Five chips have retouch along two edges, and four chips are unifacial. Four specimens (80\%) are partially corticate, and one specimen $(20 \%)$ is decorticate. Three specimens $(60 \%)$ have small retouch, and two specimens (40\%) have large retouch. The edge forms and percentage of each are as follows: five irregular edges $50 \%$, four indeterminate edges $40 \%$, and one with convex and irregular edges $10 \%$.

TWO SIDES, IRREGULAREDGES. Two specimens are partially decorticate chips with large retouch scars. One edge on one specimen is bifacial. One specimen is shown in Figure 26,f. Dimensions: ML: 5.3, MW: 5.1-4.4, MT: 2.3-1.6. Provenience: E1014 N1002, 98.60-98.50, E1029 N1001, 98.70-98.60.

TWO SIDES, CONVEX AND IRREGULAR EDGES. A decorticate chip has small retouch scars (Fig. 26,g). Dimensions: ML: 3.5, MW: 3.3, MT: 1.7. Provenience: E1029 N1001, 98.30-98.20.

TWO SIDES, INDETERMINATE EDGES. Two partially corticate chips have small retouch scars. Dimensions: ML: 5.5-1.5, MW: 1.8-1.1, MT: 1.1-0.9. Provenience: E1029 N1001, 99.20-99.10; E1029 N1001, 97.40-97.30.

Three Sides

IRREGULAR EDGES. Two decorticate chips have small retouch scars. One specimen is shown in Figure 26, h. Dimensions: ML: 5.0-4.0, MW: 2.8-2.6, MT: 0.6-0.5. Provenience: Trench 19 (2). 


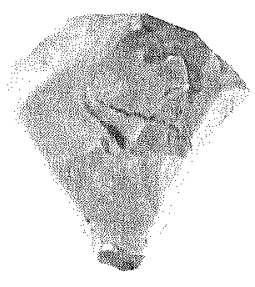

a

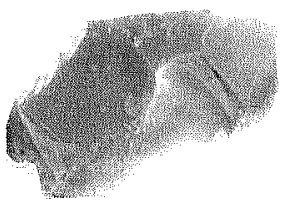

e

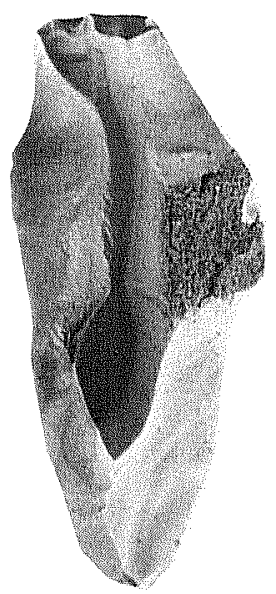

i

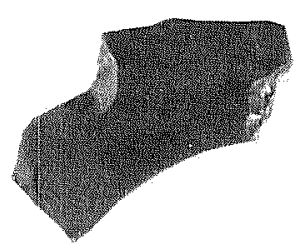

b

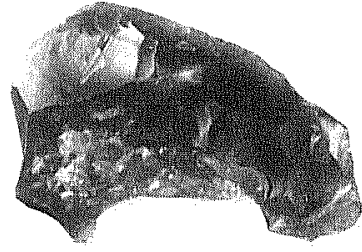

C

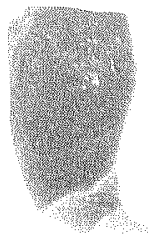

g

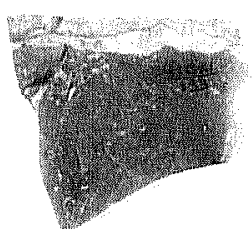

d

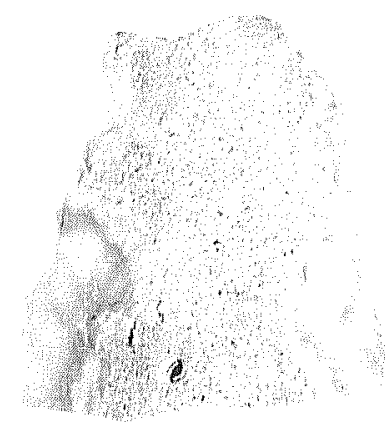

f

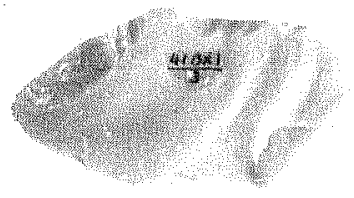

h

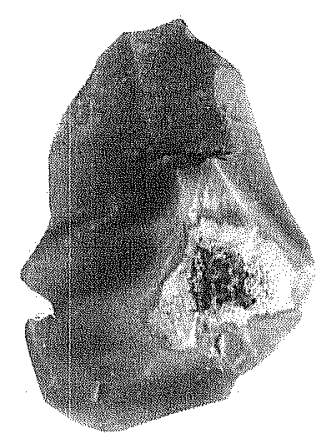

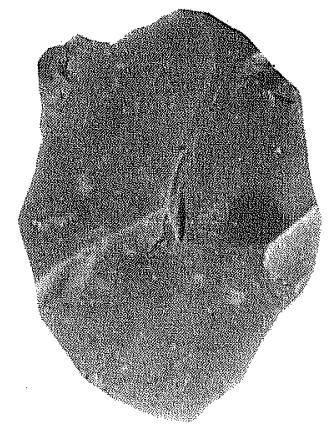
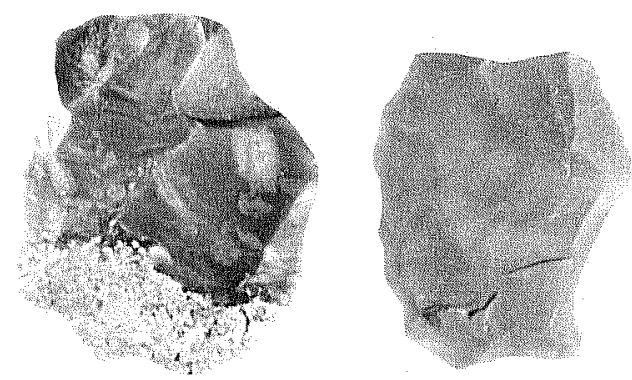

k

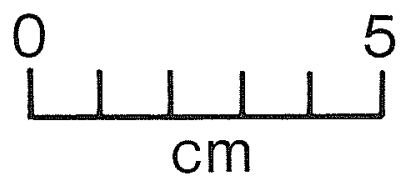

Figure 26. Retouched Chips and Modified Debitage from 41 BX 1. Retouched chips on one side: a, convex edges; b, straight edges; $c$, irregular edges; d, concave edges; e, convergent edges. Retouched chips on two sides: $f$, irregular edges; $g$, convex and irregular edges. Retouched chips on three sides: h, irregular edges; i-m, modified debitage. 


\section{Modified Flakes and Chips}

Modified flakes and chips exhibit edge damage usually described as edge "nibbling" or "nicking." The modified edges have negative flake scars less than $1 \mathrm{~mm}$ in length. Edges are usually feathered and easily subject to accidental chipping (some of the edges can be damaged simply by pressure applied with a fingernail to the edge of the specimen). In some respects, these 96 specimens are similar to retouched flakes and chips, but the edges tend to be less regularly altered. Flake scars on modified flakes tend to be spaced irregularly and show varying depth into the face of the flake, tending to give a ragged, serrated look to the specimen. Modified flakes and chips are classified according to morphological distinctions (secondary and interior). Figure 26, i-m illustrates a few of these modified flakes and chips.

\section{Modified Secondary Flakes}

The secondary flakes (18 specimens) are the largest and thickest specimens of all the modified flakes and chips. Two blades are included within this group. Dimensions: ML: 10.6-2.7. Provenience: see Appendix III.

\section{Modified Interior Flakes}

The largest group within the modified flakes and chips category is modified interior flakes ( 45 specimens). The flakes are fairly large and thin. The majority appear to be small multifaceted, lipped flakes. Fourteen specimens are bladelike, although only four specimens meet the definition presented by Crabtree (1972:42). Two specimens are burned. Dimensions: ML: 9.5-1.6. Provenience: see Appendix III.

\section{Modified Partially Corticate Chips}

The smallest group within the modified flakes and chips category is modified partially corticate chips (seven specimens). They are generally thicker and larger than the decorticate specimens. Dimensions: ML: 5.5-1.5. Provenience: see Appendix III.

\section{Modified Decorticate Chips}

A total of 26 specimens is classified as modified decorticate chips. Modified decorticate chips are similar to the modified flakes except they do not have platforms. There is only one bladelike specimen within this group, and there is one burned specimen. Dimensions: ML: 5.4-0.8. Provenience: see Appendix III.

\section{Unmodified Debitage}

A total of 14,261 specimens is classified as unmodified debitage. Unmodified debitage includes flakes (primary, secondary, and interior), chips (corticate, partially corticate, decorticate), burned chert, chunks, and quartz flakes. All are considered by-products of the chipped stone manufacturing process. Provenience of all unmodified debitage specimens is provided in Appendix III.

Flakes

A total of 5001 flakes was recovered. Flakes are chert pieces struck from a parent material (cores and tools or other flakes) representing various stages of lithic reduction. Categories are based on the amount of remaining cortex on the platform on the dorsal face of each specimen. 
PRIMARY FLAKES. Primary flakes (86 specimens) are struck from a natural platform with cortex on $100 \%$ of the dorsal face. Primary flakes are generally considered indicative of the initial stages of core reduction. Three cortex flakes were associated with features.

SECONDARY FLAKES. Secondary flakes (1094 specimens) exhibit some interior portion of the chert on the dorsal face or platform of the flake. These flakes may indicate a continuum in the core reduction process, or they may represent tool blanks. Fifteen secondary flakes were found in soil surrounding the burials, and 19 specimens were recovered from feature fill.

INTERIOR FLAKES. Interior flakes (3821 specimens) are completely decorticate. In general, these are smaller flakes than primary or secondary flakes. Sixty interior flakes were recovered from soil surrounding the burials, and 67 specimens were from feature matrix.

\section{Chips}

A total of 8447 chips was recovered. Chips are similar to flakes in that they are generally thin and flat, but they lack a bulb of percussion and a striking platform. The three categories of chips are analogous to those used for flakes. Chips probably represent the distal end or lateral sides of flakes, and their proportions covary with flakes.

CORTICATE CHIPS. Corticate chips (163 specimens) have cortex on $100 \%$ of a single face. Four corticate chips were recovered within feature fill, and three specimens were recovered from soil surrounding burials.

PARTIALly CORTICATE CHIPS. Partially corticate chips (1423 specimens) have some cortex on one face. Thirty-eight chips of this type were recovered from soil taken from around the burials; 27 specimens were from soil around features.

DECORTICATE CHIPS. Decorticate chips (6861 specimens) have no evidence of any cortex covering. As with the interior flake counts, this group has a proportionally higher specimen count than the corticate chips. One-hundred thirty-five decorticate chips were recovered from soil surrounding the burials; 145 decorticate chip specimens were from features.

\section{Burned Chert}

Burned, nonflaked chert material totals 655 specimens.

\section{Chunks}

A total of 160 chunk specimens was recovered. Chunks are small, angular, blocky pieces of chert representing debitage unintentionally created during the flint-working process. The majority (94) were recovered from outside of the burned area, in Units E1029 N1001 and E1022 N1065.

\section{Quartz Flakes}

Three quartz flakes are clear to milky white cryptocrystalline. The sizes of the specimens vary from $1.8 \mathrm{~cm}$ to $2.3 \mathrm{~cm}$, and the thicknesses vary between $0.5-0.8 \mathrm{~cm}$. Quartz flakes were found in the burial area within levels assigned to the Late to Transitional Archaic. Similar quartz flakes have been found at the Oblate site (Tunnell 1962) and Stillhouse Hollow Reservoir (Sorrow, Shafer, and Ross 1967). Provenience: E1014 N1002, 98.60-98.50; E1029 N1001, 99.00-98.90; E1029 N1001, 98.90-98.80. 


\section{Ground and Pecked Stone}

Fourteen ground stone specimens consist of grinding slab fragments and handstones. Pecked stone artifacts are represented by modified quartz cobbles and hammerstones.

\section{Grinding Slab Fragments}

Six grinding slab fragments were recovered. Grinding slab fragments are tabular forms exhibiting flat or slightly disk-shaped surfaces. Not all of the specimens show unmistakable ground facets when examined through a low power binocular microscope. It is assumed that the softer stones (limestone and sandstone) have weathered to the point that the ground facets are now gone. Of the four specimens that do not show obvious grinding surfaces, three are included here because of the general evenness and texture of the specimens (Specimens 1, 4, and 5). One specimen is included because its general shape and unusual composition are suggestive of the unused portion or edge of a larger grinding slab. Specimens 2-5 are thought to be sandstone or mudstone from either the Wilcox or Midway geologic groups (Barnes 1974) which are exposed in the Gulf Coastal Plain within eight miles of the Olmos Basin.

SPECIMEN 1. Specimen 1 (Fig. 27,a) is a single-faceted, slightly disk-shaped fragment of burned limestone. Dimensions: ML: 12.8, MW: 9.8, MT: 2.5. Provenience: E1014 N1002, 98.40-98.30.

SPECIMEN 2. Specimen 2 (Fig. 27,c) is a double-faceted, roughly rectangular-shaped tabular specimen with breaks on all four edges (i.e., specimen is not pecked into shape). The material is a dusky yellow laminated sandstone. Dimensions: ML: 24.3, MW: 20.0, MT: 3.0. Provenience: Burial 2,98.33.

SPECIMEN 3. Specimen 3 is an edge fragment, possibly the unused portion or end of a large grinding slab. There are no indications of any wear facets on the specimen. The material is a dusky yellow sandstone. Dimensions: ML: 14.3, MW: 14.2, MT: 3.2. Provenience: E1012 N1002, 98.20-98.10.

SPECIMEN 4. Specimen 4 is a double-faceted, flat, tabular-shaped fragment. Material and color are very similar to Specimens 2 and 3. Dimensions: ML: 12.1, MW: 7.4, MT: 2.2. Provenience: Zone 2 of Area $\mathrm{B}$ backdirt (listed with general surface collection in Appendix III).

SPECIMEN 5. Specimen 5 is identical to Specimen 4, except for its size. Dimensions: ML: 4.2, MW: 4.1, MT: 1.0. Provenience: Zone 2 of Area B backdirt (listed with general surface collection in Appendix III).

SPECIMEN 6. Specimen 6 (Fig. 27,b) is approximately half of a well-made bifaceted, slightly basin-shaped grinding slab. The end along the long axis is shaped by chipping and pecking. Material is a white chert limestone. Dimensions: ML: (17.9), MW: 16.7, MT: 3.8. Provenience: Zone 2 of Area B backdirt (listed with general surface collection in Appendix III).

\section{Handstones}

A total of three handstones was recovered. Handstones are modified cobbles, generally oval in outline, and conveniently held in one hand. Modification is a result of grinding, but pecking may also be present.

SPECIMEN 1. Specimen 1 (Fig. 28,e) is single faceted with a convex working surface. Battering along the edges of the specimen indicates use as a hammerstone. Material is a white chert limestone. Dimensions: ML: 10.2, MW: 9.5, MT: 4.5. Provenience: E1015 N1000, 98.40-98.30.

SPECIMEN 2. Specimen 2 (Fig. $28, \mathrm{~g}$ ) is double faceted with convex working surfaces and a subrectangular outline. All edges have been pecked into shape, but the two edges parallel to the long axis have been smoothed and ground. Striations follow the long axis. Material is a yellowish brown chert. Dimensions: ML: 11.7, MW: 8.6, MT: 5.2. Provenience: Zone 2 of Area B, general surface (Appendix III). 


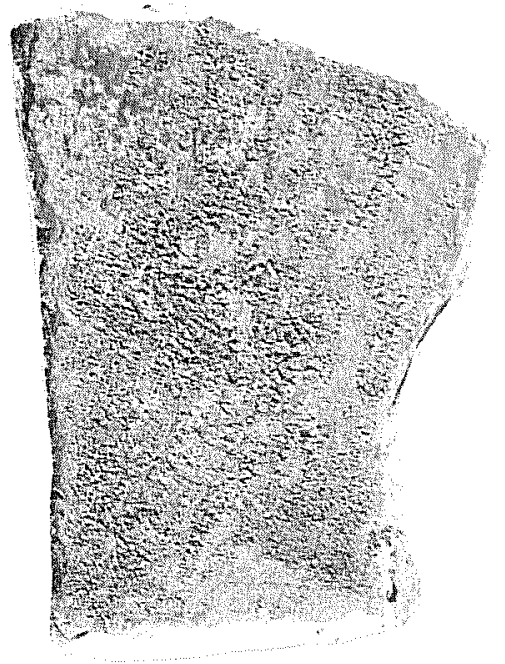

a

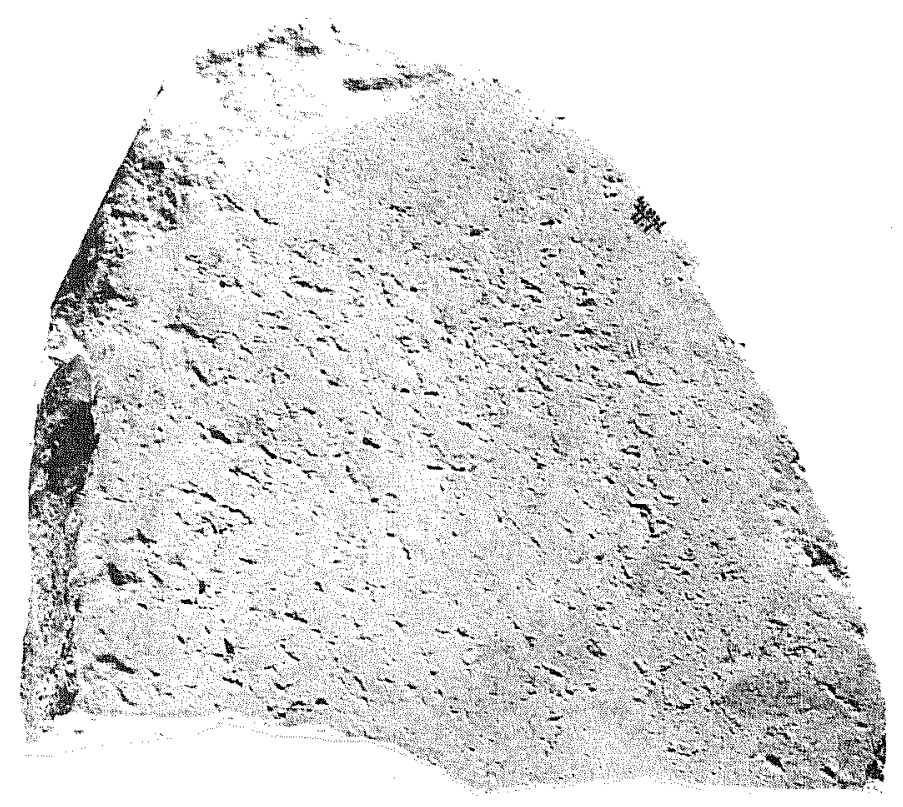

b

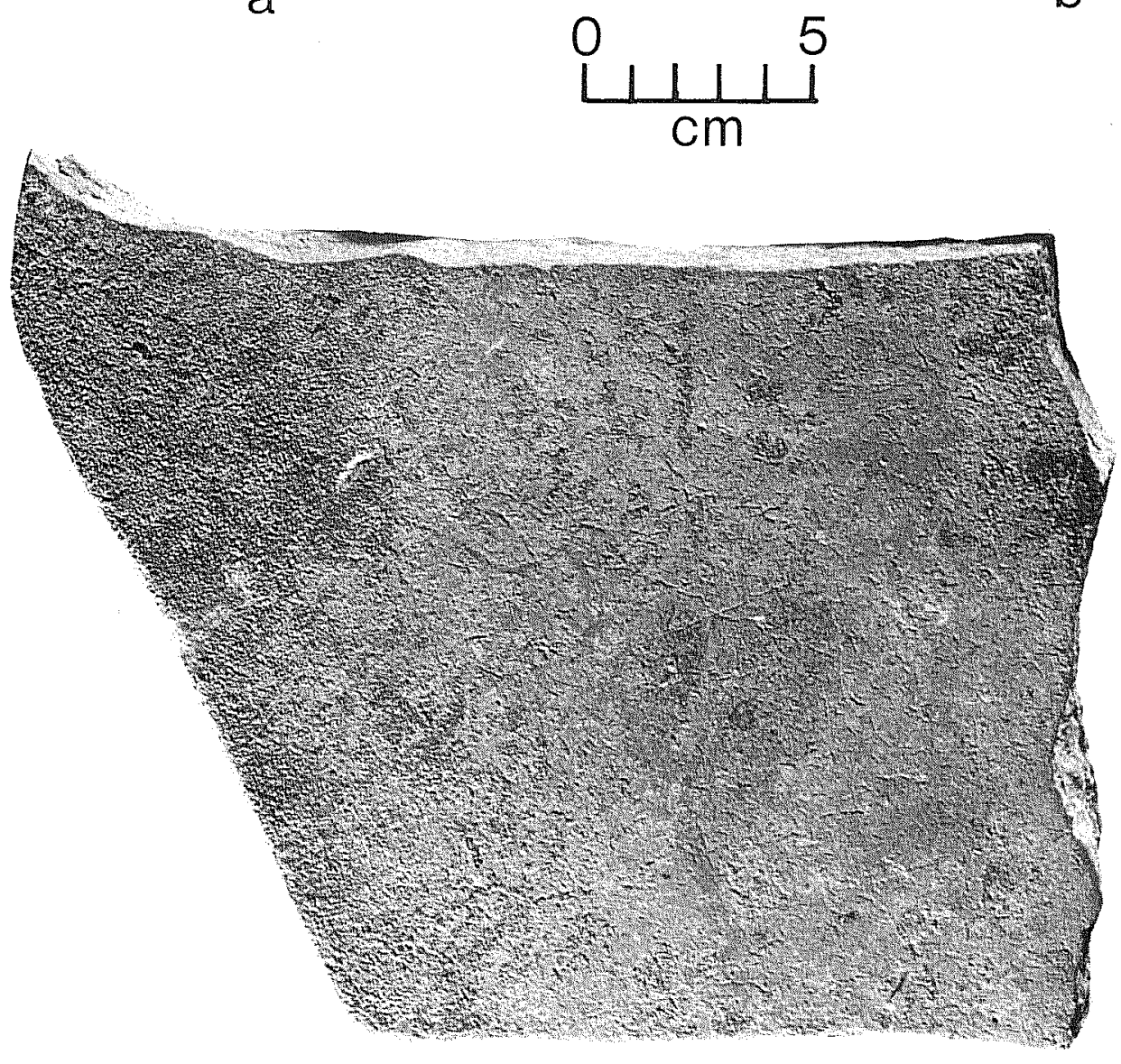

C

Figure 27. Grinding Slab Fragments from 41 BX 1. a, Specimen 1; b, Specimen 6; c, Specimen 2. 

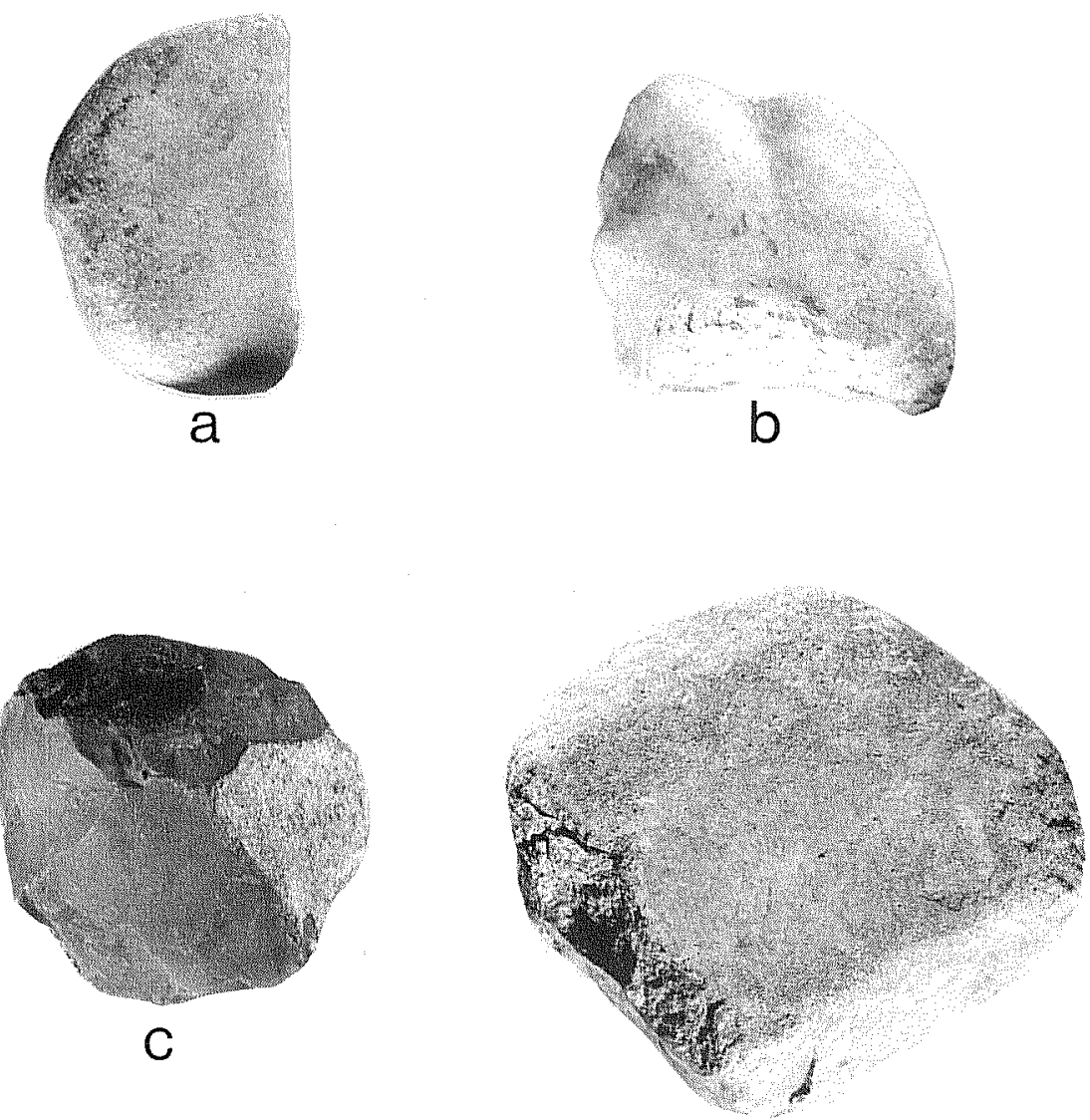

C

d

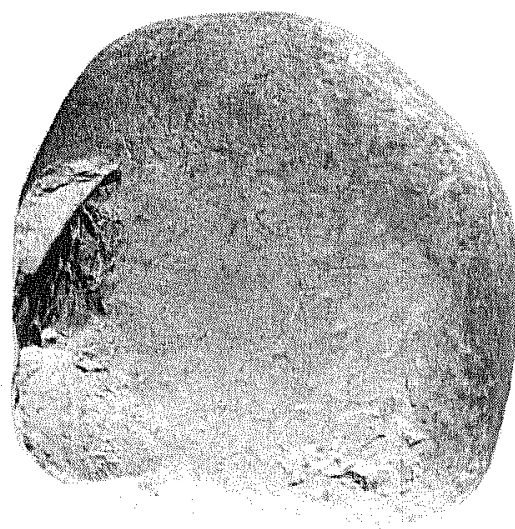

e
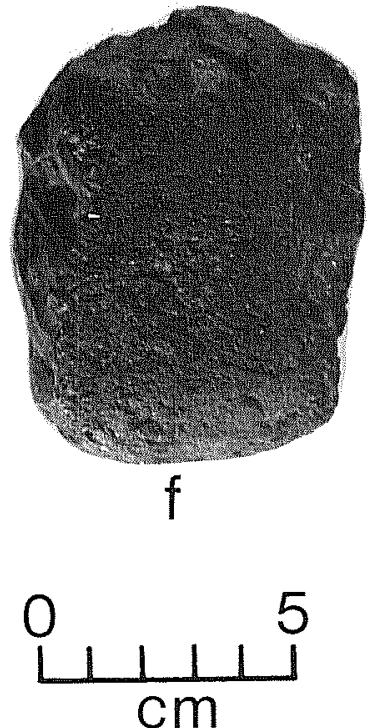

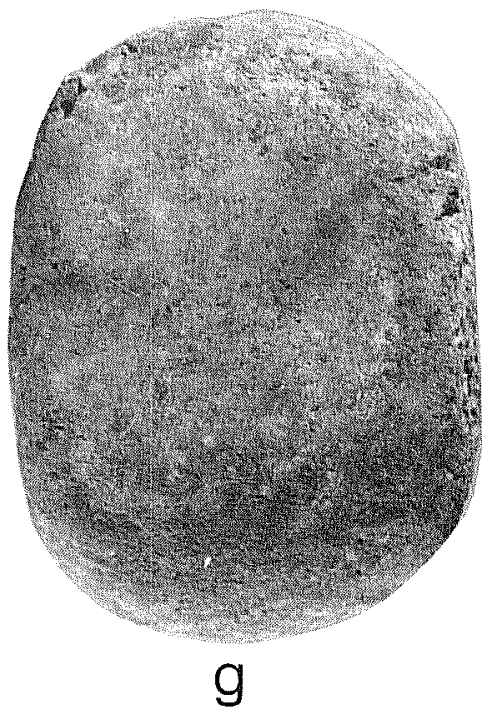

Figure 28. Handstones, Hammerstones, and Modified Quartz Cobbles from 41 BX 1. Modified quartz cobbles: a, Specimen 1; b, Specimen 2. Hammerstones: c, Specimen 2; d, Specimen 1. Handstones: e, Specimen 1; f, Specimen 3; g, Specimen 2. 
SPECIMEN 3. Specimen 3 (Fig. $28, \mathrm{f}$ ) is double faceted with convex working surfaces. One face shows a small depression approximately $1.8 \mathrm{~cm}$ in diameter and located in the center of the working area, possibly caused by battering or pecking. Edges also show some battering wear. Material is a dark gray chert with a dusky red cortex covering. The specimen is burned. Dimensions: ML: 8.7, MW: 6.7, MT: 4.3. Provenience: E1029 N1001, 99.10-99.00.

\section{Hammerstones}

Three cobbles show signs of battering or crushing along the edges or margins and are classified as hammerstones.

SPECIMEN 1. In addition to battered edges, several small negative flake scars occur sporadically along the edges of a white chert limestone cobble (Fig. 28,d). Dimensions: ML: 10.1, MW: 10.0., MT: 5.5. Provenience: Zone 3, backdirt (general surface collection in Appendix III).

SPECIMEN 2. Specimen 2 (Fig. 28,c) has the general appearance of a heavily stream-rolled multidirectional core. All edges are battered. Material is a grayish brown chert. Dimensions: ML: 7.7, MW: 7.0, MT: 6.1. Provenience: E1012 N1002, 98.80-98.70.

SPECIMEN 3. Sporadic, widely spaced light peck marks occur along one edge. Material is chert with a brown cortex. Dimensions: ML: 7.4, MW: 4.7, MT: 3.9. Provenience: E1022 N1065, 99.50-99.40.

\section{Modified Quartz Cobbles}

Modified quartz cobbles are pecked or battered, and the material is milky white crystalline quartz.

SPECIMEN 1. Specimen 1 (Fig. 28,a) is a fragment of a cobble very heavily pecked into shape along the unbroken edges. The edges are pecked flat and extend to the maximum thickness of the specimen. This specimen appears quite distinct from hammerstones or shaped handstones. Dimensions: ML: 7.4, MW: 4.7, MT: 3.9. Provenience: Zone 2 of Area A (general surface collection in Appendix III).

SPECIMEN 2. Specimen 2 (Fig. $28, \mathrm{~b}$ ) is a fragment of a cobble lightly pecked on one end. Dimensions: ML: 7.4, MW: 4.7, MT: 3.9. Provenience: E1010 N1000, 98.40-98.30.

\section{$\underline{\text { Burned Clay }}$}

Burned clay usually occurred as small nodules scattered throughout all the unit-levels. Small nodules of clay were scattered in the soil matrix, and sometimes found in larger concentrations (for example, Feature 10). A total of $4.1 \mathrm{~kg}$ of burned clay was collected from various unit-levels.

\section{$\underline{\text { Burned Rock }}$}

Bluish gray fire-fractured limest one was present in all areas and levels excavated. A total of 5253 specimens was collected. Burned limestone rocks tended to be outside of the burial area, increasing in Levels 2 and 9-12 in Unit E1029 N1001 and in Levels 2 and 3 of Unit E1022 N1065. Generally burned limestone was counted and weighed $(995.4 \mathrm{~kg}$ ) in the field, and then discarded. Incidentally or intentionally collected specimens brought into the laboratory were kept as samples. 
Unmodified/Natural Materials

Unmodified/natural materials are tested cobbles, unmodified cobbles, ocher, hematite, and fossils.

\section{Tested Cobbles}

Eight tested cobbles have one or two flakes struck from a natural platform. The four largest cobbles are associated with Burial 2 and Feature 2. One cobble associated with Burial 2 is a halved sphere with a crystalline-lined cavity in the center. Of the four cobbles not associated with burials, weights range from $125.4 \mathrm{~g}$ to $446.7 \mathrm{~g}$. Weights for the cobbles associated with burials range from $1686.8 \mathrm{~g}$ to $2423.6 \mathrm{~g}$. Dimensions: Larger four specimens, ML: 22.5-15.0, MW: 16.0-9.0, MT: 13.0-6.0; smaller four specimens, ML: 9.6-9.4, MW: 8.5-5.9, MT: 4.7-3.5. Provenience: E1010 N1000, 98.40-98.30; E1029 N1001, 99.30-99.20; Feature 2 (2); Burial 2 (2); general surface collection (2).

\section{Unmodified Cobbles}

Fourteen unmodified cobbles were collected. They are made of chert, limestone, or quartzite and have no alterations or wear patterns. All have a maximum dimension of over $5 \mathrm{~cm}$. These specimens may represent raw materials brought into the site for later use, or they may represent tools with no recognizable wear patterns. The three largest chert specimens were from Feature 2. An unburned limestone cobble was from the surface of Area A. A quartzite specimen was from E1010 N1000, 98.40-98.30. All other specimens are made of chert. Dimensions: larger three specimens, ML: 17.0-16.0, MW: 16.0-11.0, MT: 9.5-8.0; smaller specimens, ML: 12.5-5.5, MW: 8.0-3.3, MT: 5.4-2.0. Provenience: E1010 N1000, 98.40-98.30; E1012 N1002, 98.60-98.50 (2); E1012 N1002, 98.00-97.90; E1014 N1001, 98.20-98.10; E1022 N1065, 98.50-98.40 (2); E1022 N1065, 99.20-99.10; E1029 N1001, 99.30-99.20; Feature 2 (3); Area A surface (2).

\section{Ocher}

Ocher is an earthy mineral oxide that generally occurred at the site as stains or as very small pellets. Occasionally larger pellets were found, but no wear facets or incisions were noted on any of the specimens. Virtually all of the ocher was a dark reddish to rust color, except for two samples of yellowish ocher. Ocher was found in all areas of the site and was concentrated within the cemetery area. A total of 76 samples was collected of varying sizes and quantity. The presence and/or absence of ocher in each unit-level is noted in Appendix III.

\section{Hematite}

Hematite is a reddish mineral oxide that is much harder than ocher. It generally occurs as small concretions or spherical nodules less than $2 \mathrm{~cm}$ in maximum length. Hematite was scattered within all areas of the site.

Fossils

Five specimens of fossil shells were recovered from five units. Provenience: E1029 N1001, 99.20-99.10; E1029 N1001, 99.10-99.00; E1029 N1001, 97.40-97.30; E1014 N1002, 98.20-98.10; E1015 N1000, 98.40-98.30.

\section{CERAMICS}

Two sherds are in the collection, one from a disturbed surface context between Zone 2 and the dam face and one from trench backdirt in Zone 3. The two sherds have dark gray clay paste interiors with bone tempering. 
One specimen is highly burnished on both surfaces. Although both could be classified as Leon Plain, they are probably not from the same vessel (Anne Fox, personal communication). The specimens are $1.7-1.9 \mathrm{~cm}$ in size. The walls are $0.4-0.6 \mathrm{~cm}$ thick.

\section{DEER ANTLER BASES}

Only those sections of antler beam in which the antler base was represented were counted in the total of 81 specimens. The majority of antler was in very poor condition and tended to fragment when removed from context.

Seven of the deer antler bases are from the surface, seven are from unit-levels, and 67 are associated with burials (see Appendix IV). Twenty-three of the bases have been identified as from white-tailed deer (Caras 1967:432). Only three of the specimens might be considered to have been shed antler, the remainder were associated with deer skull fragments.

\section{GASTROPOD REMAINS}

A total of 17,896 gastropod specimens was collected. The six snail genera identified, listed in order of maximum numbers represented, include Helicina sp., Rabdotus, Polygyra, Praticolella, Helisoma, and Succinea. Helicina and Rabdotus were much more common than any of the others and together represent approximately two-thirds of the total sample. As snails were not consistently collected from every unit, no quantitative data are presented.

\section{SHELL}

Both modified and unmodified shells of marine or freshwater origin were collected. Marine shells are identified as lightning whelk (Busycon contrarium) and horse conch (Pleuroploca gigantea). Freshwater shell includes various species.

Marine Shell

Conch pendants, a marine shell fragment, and columella pendants represent the marine shell collected at $41 \mathrm{BX} 1$.

\section{Conch Pendants}

All seven conch pendants collected represent grave goods except Specimen 1. All specimens exhibit punctate designs of small, shallowly drilled pits on the interior (or concave) face except Specimen 6. Specimens 3 and 7 are notched along the margins of the shell. Design elements generally consist of double rows of closely spaced punctates forming variants of "cross" $(+)$ and "inverted broken cross" $(\lambda)$ designs. All specimens have drilled holes near the apex, and five (Specimens 1-2, 5-7) have drilled holes near the opposite end of the long axis (long axis runs through the apex of every specimen).

The conch pendants are similar to Hall's (1981:203, Fig. 47) shell pendants Form 7 and Form 11. All specimens are made of sinistrally spiraled body whorls. It is assumed the specimens are of Busycon contrarium (see Hall 1981 for discussion). The shells are a light cream to chalky white color (Andrews 1971). Body whorl pendants, some with punctates have been reported from various coastal sites (Campbell 1952; Aten et al. 1976) and also inland, as in the A. E. Anderson collection (TARL), at the Morhiss site (Campbell 1976), at the Loma Sandia site (C. Johnson, personal communication), and at various sites in central Texas (Prewitt 1974). 
SPECIMEN 1. Specimen 1 (Fig. 29,a) is roughly subtriangular in outline. The specimen has two drilled holes located less than $3 \mathrm{~mm}$ away from either edge along the long axis. Both holes are biconical. The hole toward the narrow end (anterior portion of whelk) is elongated, indicating use-wear. The design element consists of double row punctates forming a cross on the interior or concave face. The parallel rows are spaced very closely to $5 \mathrm{~mm}$ apart. Punctates along a line are spaced approximately $5 \mathrm{~mm}$ apart. The rows are drilled so that the vertical and horizontal bars of the cross design meet at midpoint. Edges and both interior and exterior faces are polished and smoothed.

Specimen 1 is the smallest body whorl pendant from the site. It is also the only specimen that was not associated with a burial. The cross pattern appears on Specimens 2 and 7, both associated with separate burials. Dimensions: ML: 6.7, MW: 4.6, MT: 0.3. Provenience: E1013 N998, Level 1 (98.41-98.30).

SPECIMEN 2. Specimen 2 (Fig. 29,b) has a subtriangular outline and two drilled holes located $7 \mathrm{~mm}$ and $3 \mathrm{~mm}$ from either end along the long axis of the pendant. Both holes are biconical. The hole near the narrow, or anterior portion, is elongated toward the edge of the specimen, indicating use-wear. Two very shallow smooth grooves can be felt along the edge of the hole to the end of the specimen; this is also interpreted as wear. The design is a cross utilizing triple row, double row, and single line punctates on the interior or concave face. The triple row punctate design runs along the long axis, end to end. The cross bar design is located at approximately two-thirds the distance from the wide end to the apex (anterior end). Facing the specimen, with the apex up, the cross design has a double row of punctates to the right and a single line of punctates to the left. Edges and both interior and exterior faces are well smoothed and polished.

Specimen 2 was recovered with Burial 1, an infant. The pendant was situated above the postinterment displaced bone fragments of this burial in what is assumed to be the chest area. Dimensions: ML: 11.4, MW: 7.6, MT: 0.4. Provenience: E1012 N998, Level 2 (98.40-98.30), Burial 1.

SPECIMEN 3. Specimen 3 (Fig. 30,a) has a subtriangular to trapezoidal outline. There are two biconical holes towards the anterior end of the shell, spaced $4 \mathrm{~mm}$ from the anterior edge and $5 \mathrm{~mm}$ apart on either side of the long axis. No wear pattern is obvious on the hole edges. The design consists of punctates on the interior face and notching on the edges. The punctate design is a closely spaced double row, extending up the long axis of the specimen from the shoulder edge to a little more than three-fourths of the total distance to the apex. A "gap" in this double row pattern is a single line of five punctates (in line with the left column if oriented with the anterior end of the shell as the apex). Whether intentional or not, it looks as if the maker neglected to complete a central portion of the double row design. Continuing up the long axis is a change to a single line of punctates arranged in a zigzag pattern that changes directions three times before ending at the hole on the left side (viewed with apex up) of the specimen.

All except the anterior edge of the specimen are notched with shallow cuts "V" to "U"-shaped and 2 to $4 \mathrm{~mm}$ apart. Both faces are smoothed and polished.

Specimen 3 was recovered with Burial 2. There are red ocher traces within some of the punctates, but intentional placement cannot be inferred. The artifact was in a position close to the neck. Two columella dangles (Specimens 1 and 4) were recovered very close to and either side of the pendant, suggesting the possibility that they were suspended from the neck by the same cord. Dimensions: ML: $9.6, \mathrm{MW}: 8.1, \mathrm{MT}$ : 0.4. Provenience: Burial 2.

SPECIMEN 4. Specimen 4 (Fig. 31,d) has a subtriangular outline. There is a single biconical, drilled hole $3 \mathrm{~mm}$ from the anterior edge. Very slight elongation of the hole indicates some wear. The design consists of punctates on the interior face of the artifact. There is a triple row of punctates down the long axis from the shoulder to nearly two-thirds of the total length. At this point along the axis, the design is reduced to a double row punctate design that continues up to the drilled hole. At the point where the design changes, there is a single line of punctates running perpendicular to the long axis. At points near either end of this perpendicular line begin double row punctates that extend to the shoulder edge of the specimen, slightly expanding away from the long axis as the artifact broadens. Both faces are smoothed and polished, and all 

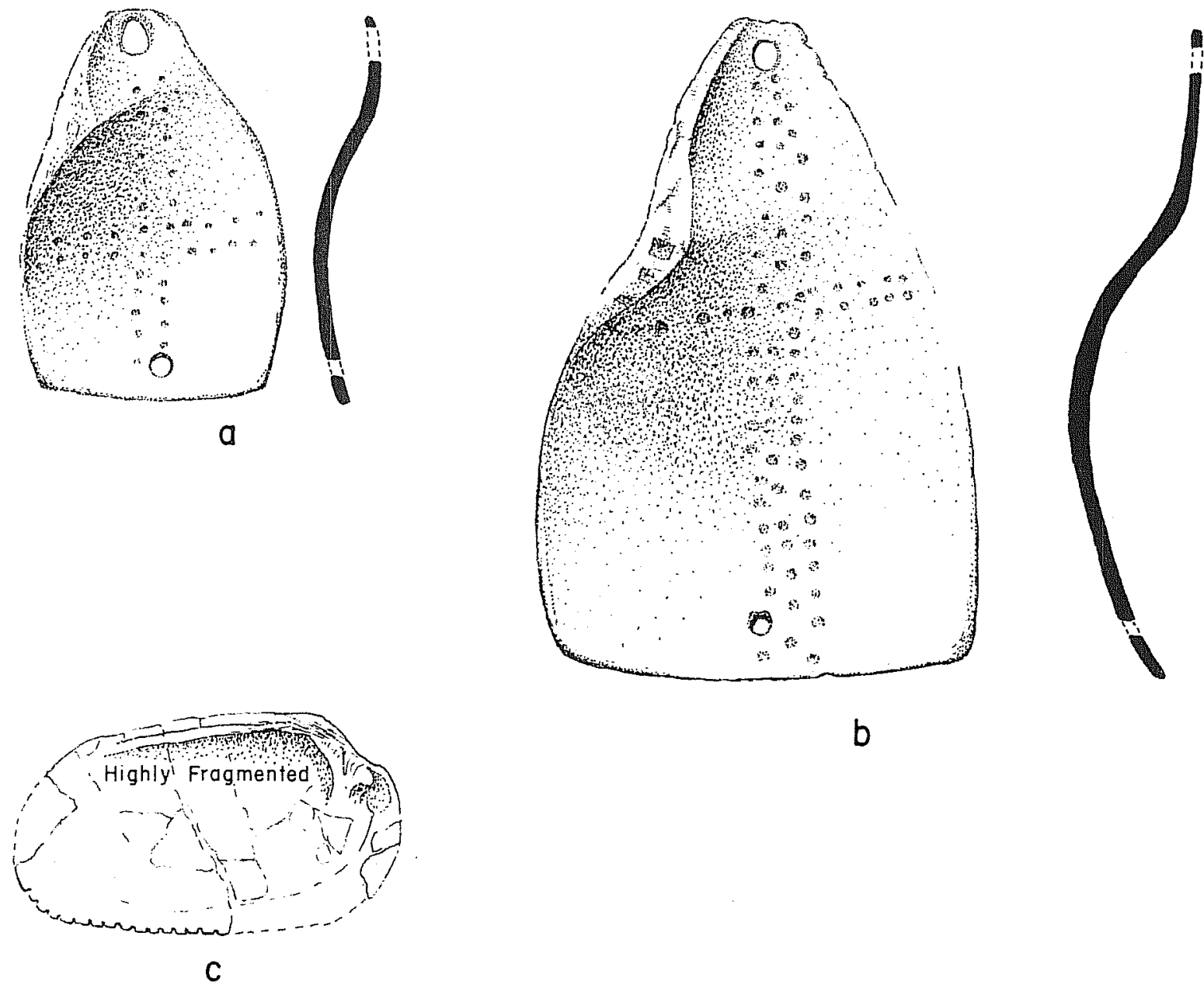

b

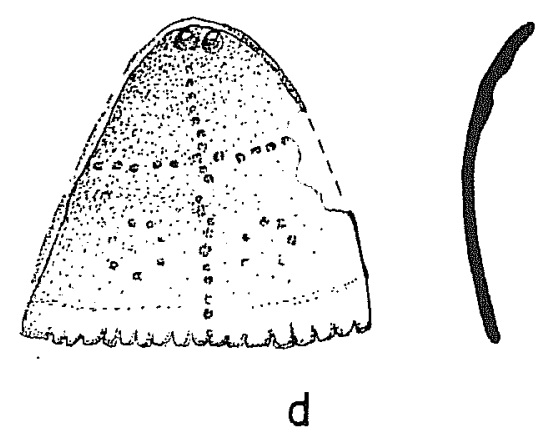

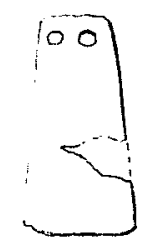

e
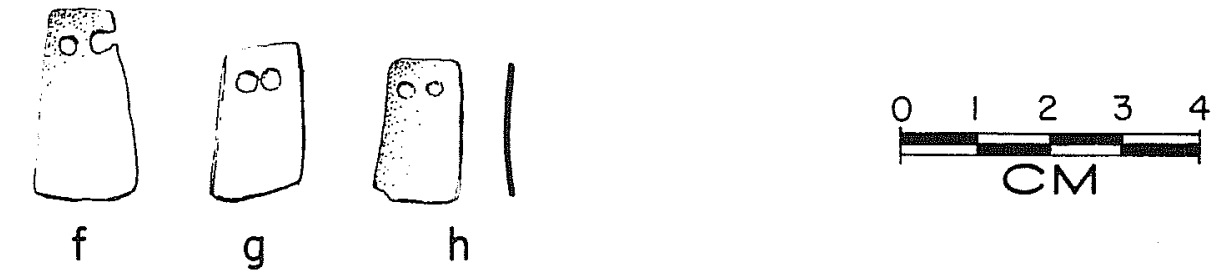

\section{K.L.E. iage}

Figure 29. Conch Pendants and Mussel Shell Pendants from 41 BX 1. a, conch pendant, Specimen 1; b, conch pendant, Specimen 2; $c$, notched mussel shell; d, punctated and notched mussel shell pendant; e-h, rectangular mussel shell pendants. 

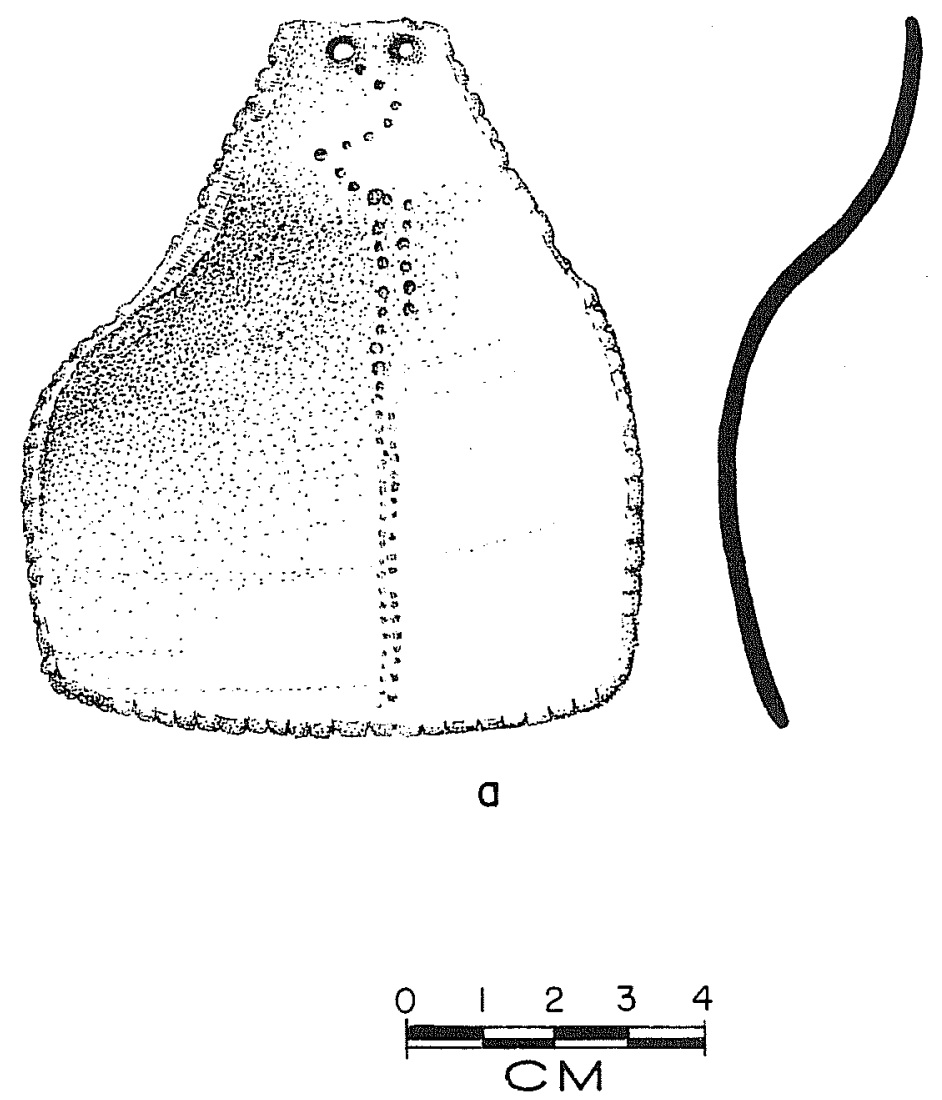

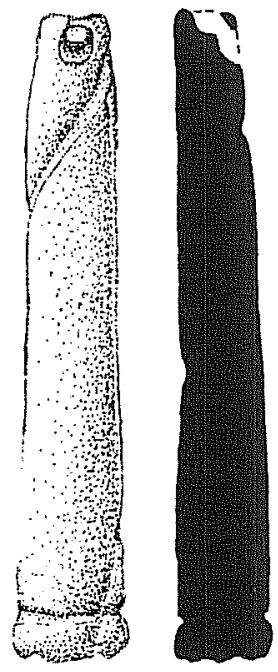

b
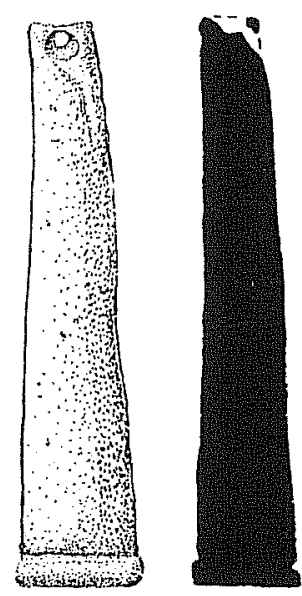

d

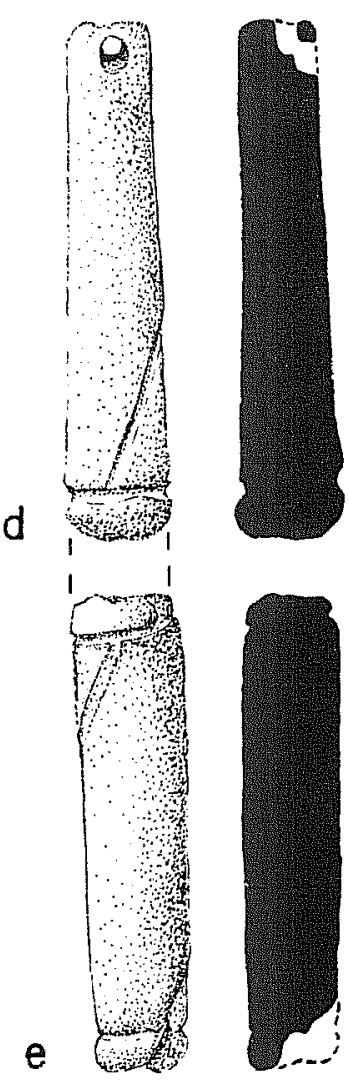

C

Figure 30. Conch Pendant and Columella Pendants from 41 BX 1. a, conch pendant, Specimen 3; b, columella pendant, Specimen 4 ; c, columella pendant, Specimen 3; d, columella pendant, Specimen 1; e, columella pendant, Specimen 2. 


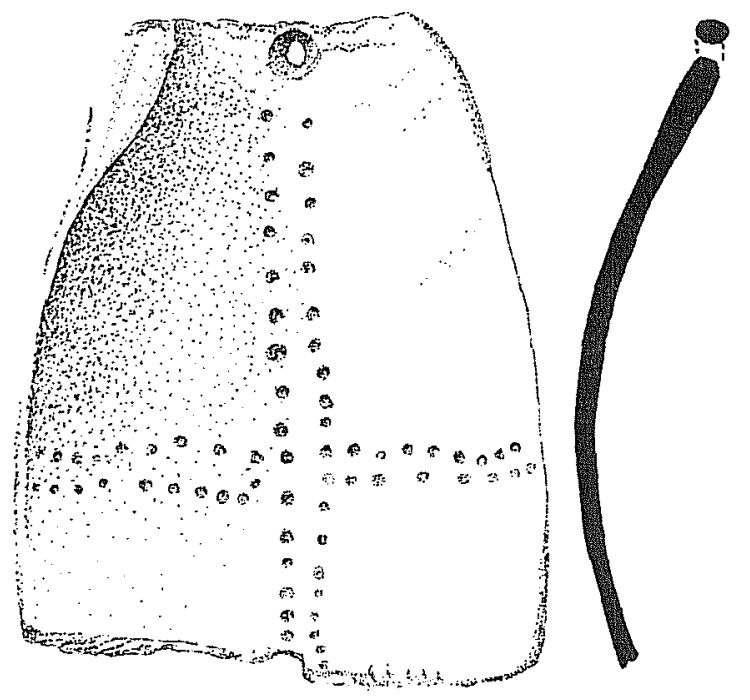

$a$

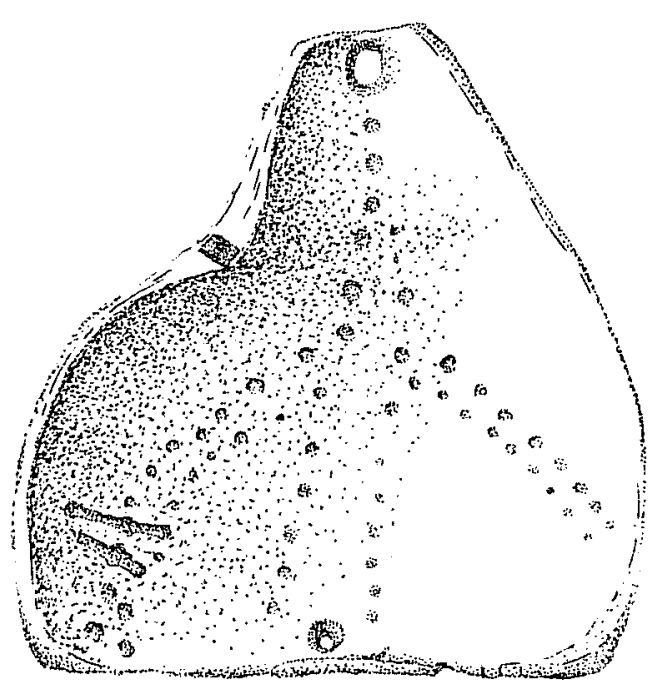

b
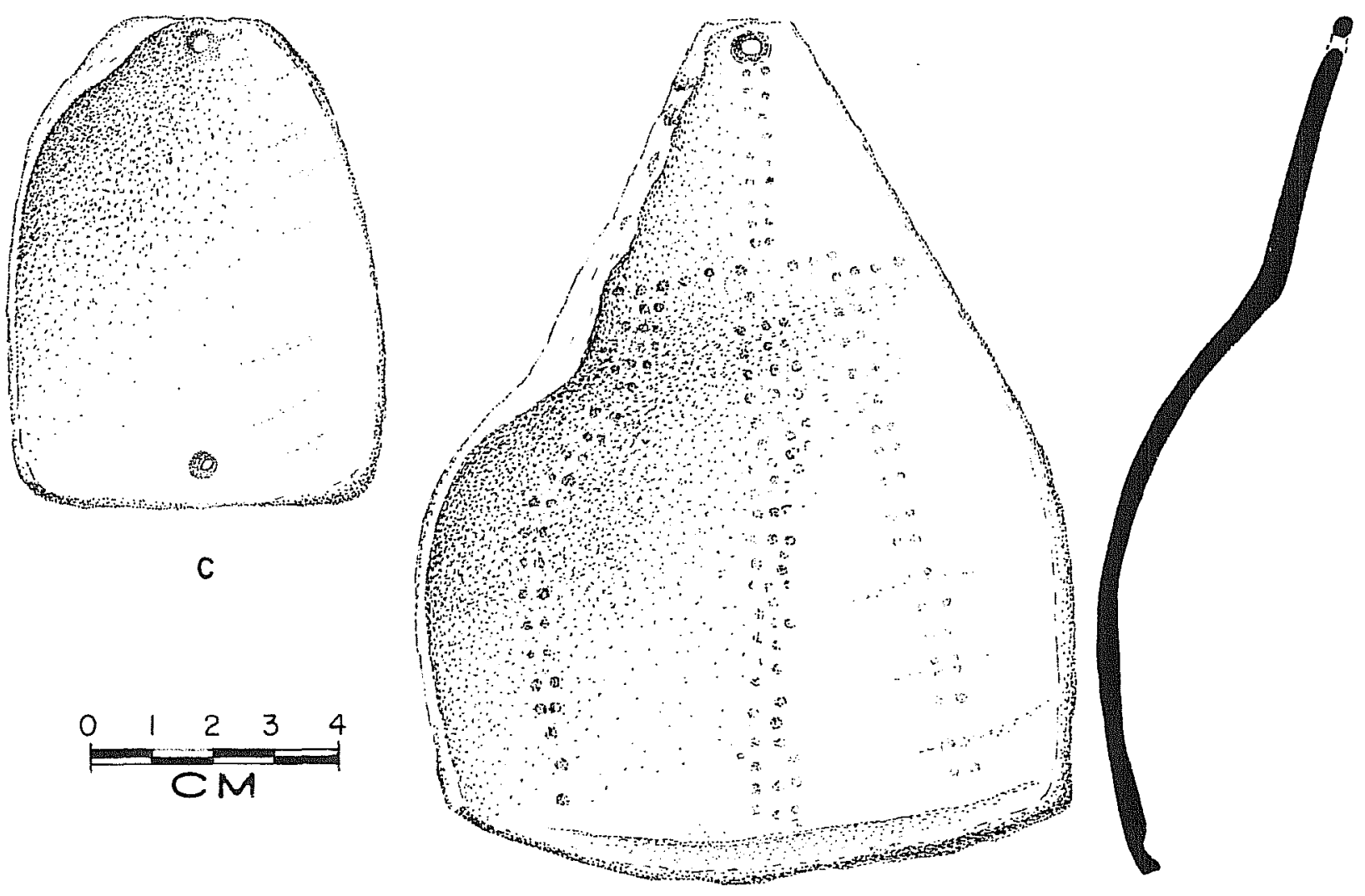

d

Figure 31. Conch Pendants from 41 BX 1. a, Specimen 7; b, Specimen 5; c, Specimen 6; d, Specimen 4. 
edges are smoothed. A portion of an edge on one side near the anterior has been roughly smoothed, but still exhibits ragged edges that may reveal one of the earlier manufacturing stages.

Specimen 4 is one of four specimens associated with Burial 10. It is also the largest specimen recovered. The specimen is fairly weathered, and the punctate designs are difficult to see. Dimensions: ML: 13.8, MW: 10.5, MT: 0.6. Provenience: Burial 10.

SPECIMEN 5. The subtriangular outline of Specimen 5 (Fig. 31,b) is less regular than the other specimens. There are two biconical drilled holes along the long axis, each $3 \mathrm{~mm}$ from either edge. The hole on the anterior end is oval, clearly showing wear. The design consists of punctates. On either side of the hole near the shoulder are single lines of punctates that gradually taper together and become a single row towards the anterior of the specimen. At approximately midpoint on the long axis two evenly spaced double rows of punctates expand outward on either side of the long axis toward the far edges of the shoulder. The edges and both the interior and exterior faces are well smoothed and polished.

Specimen 5 is one of four pendants associated with Burial 10, near the occipital bone of the skull. Specimen 6 was lying directly above this pendant, situated so that the interior face of Specimen 5 was almost touching the exterior face of Specimen 6 . Anterior holes of both specimens were roughly aligned, possibly indicating that both specimens were strung from the same cord around the neck. Specimen 7 was also close by, but less distinctly associated with the other two pendants. Dimensions: ML: 8.4, MW: 8.2, MT: 0.4. Provenience: Burial 10.

SPECIMEN 6. Specimen 6 (Fig. 31,c) is subrectangular in outline. Near both edges of the specimen along the long axis are two biconically drilled holes. The hole towards the anterior end has a cut mark crossing it on the exterior face. Both faces are polished, and the edges are smooth and polished.

Specimen 6 is one of four pendants associated with Burial 10. This is the only specimen without a punctate design. Specimen 6 directly covered Specimen 5 (see remarks for Specimen 5). Dimensions: ML: 7.8, MW: 6.0, MT: 0.2. Provenience: Burial 10.

SPECIMEN 7. Specimen 7 (Fig. 31,a) has a trapezoidal outline. Near the outer edges of the specimen and on either end of the long axis are two biconically drilled holes. The hole toward the shoulder is crossed by a weathered snap toward the shoulder. The design element is a double row punctate cross. Cross bars perpendicular to the long axis of the specimen are at approximately midpoint of the long axis. Both faces are polished, and the edges are smoothed. Eight faint indentations or notches, spaced approximately $2 \mathrm{~mm}$ apart, can be seen on the unbroken edge toward the shoulder.

Specimen 7 is one of four pendants associated with Burial 10. It was located near the occipital bone of the skull. Dimensions: ML: 9.3, MW: 7.3, MT: 0.03. Provenience: Burial 10.

\section{Marine Shell Fragment}

Both faces of a marine shell fragment appear to be polished. All edges show rough, sharp breaks. This is probably a central fragment of a conch body whorl pendant. Dimensions: $2.5 \mathrm{~cm} \times 2.1 \mathrm{~cm} \times 0.1 \mathrm{~cm}$. Provenience: E1012 N1002, 98.30-98.20.

\section{Columella Pendants}

The four columella specimens are cylindrical sections, slightly tapered at one end. Two conical holes, averaging 3-5 $\mathrm{mm}$ in diameter, have been drilled into each specimen. The holes are drilled perpendicular to meet each other, entering the specimen from the top and side. The holes are drilled near the narrowest, or slightly tapered, end of each specimen. All four specimens have an incised line running the circumference of the end opposite the drilled holes. These incised lines are approximately $5 \mathrm{~mm}$ from the end of each 
specimen. Specimens 2 and 3 have similar incised lines that cross the holes drilled into the sides of the more tapered end. These two specimens also have either completely worn through or weathered to the point that the drilled holes are not closed but appear as gaps or channels (Specimen 2, Fig. 30,e), or very nearly so (Specimen 3, Fig. 30,c). Specimens 1 and 2 represent a single columella snapped in half to create two pendants. Specimens 2 and 3 are assumed to represent similarly snapped pendants because of their overall shape (tapered at one end only), but they could not be fitted together as was the case with Specimens 1 and 2. The whorl margin (the indentation or groove) indicates all the specimens are a dextrally spiraled conch species and not Busycon contrarium, which is sinistrally spiraled. Because of their size, they are assumed to be horse conch (Pleuroploca gigantea; Hester n.d.:2-3) which occurs less commonly (Calhoun n.d.; Campbell 1952) than the lightning whelk (Busycon contrarium).

No references to columella dangles or pendants similar to these four specimens could be found in the literature. However, specimens that have been similarly drilled, but on both ends and probably strung as necklaces, have been reported by Hall (1981, see Shell Beads, Form 5), Hudgeons and Hester (1977), and Greer (1977).

The context of Specimen 1 (Fig. 30,d) and Specimen 4 (Fig. 30,b) in relationship to a conch body whorl pendant (Specimen 3) strongly indicates that the columella specimens were suspended around the neck and on either side of the body whorl pendant. Specimens 2 and 3, with their broken or very weak stringing holes, combined with their context just slightly away from the burial may indicate they were not in use as ornaments, but possibly awaiting repairs or modification when they were selected as grave inclusions. Dimensions: Abbreviations not previously used are MDT which represents maximum diameter of the tapered end of the specimen, MDB which represents maximum diameter of the base, or end opposite the drilled holes. Specimen 1: ML: 6.7, MDT: 1.1, MDB: 1.4; Specimen 2: ML: 6.4, MDT: 1.1, MDB: 1.4; Specimen 3: ML: 7.6, MDT: 1.1, MDB: 1.5; Specimen 4: ML: 8.9, MDT: 1.0, MDB: 3.0. Provenience: Burial 2.

Freshwater Shell

A punctated and notched mussel shell pendant, rectangular mussel pendants, notched mussel shell, unidentifiable unmodified mussel shell fragments, and a crustacean fragment represent the freshwater shell.

\section{Punctated and Notched Mussel Shell Pendant}

A punctated and notched mussel shell pendant (Fig. 29,d) has a subtriangular outline with two closely spaced conical holes, drilled from the interior face of the shell, near the apex. The punctate design consists of a cross element formed by two single rows of punctates that extend the length and width of the specimen. Below the horizontal bar of the cross, and on either side of the vertical bar are two punctated circular designs, each approximately one centimeter in diameter. Along the interior rim of the ventral margin of the shell are 18 notches.

Somewhat similar mussel shell pendants have been recovered from the Oblate site (Tunnell 1962:113, Fig. J) and 41 BX 167 (notes on file, CAR-UTSA). The specimen from 41 BX 167 was a circular disk with a small drilled hole near one edge. The artifact is apparently from a Late Prehistoric cemetery as Scallorn points have been reported by informants in association with human skeletal remains at this site. Dimensions: ML: 4.3, MW: 4.9, MT: 0.2. Provenience: E1022 N1065, 99.50-99.40.

\section{Rectangular Mussel Shell Pendants}

The cut mussel shell pendants (60 specimens) are rectangular to trapezoidal in outline (Fig. 29,e-h). On each specimen are two small holes (approximately 1-2 mm in diameter) near the edge of the narrowest end. The holes are generally conical, drilled from the interior, but variations occur. None of the specimens have any punctates or notches. Fifty-three specimens have drilled holes, and one fragment had a base. Additional 
fragments identified as cut mussel pendants but not complete enough to determine a complete specimen are excluded from the total count. Five or more specimens may be represented by these fragments.

These pendants were restricted to the burial area and were associated with six burials. Two burials contained clusters of mussel shell strongly indicative of necklaces (pendants were grouped near the base of the skull).

Two kinds of ornamental mussel shell have been identified in the literature, those with altered or notched edges, and those with a simple rectangular to trapezoidal outline (see Tunnell 1962:113; Fox, Bass, and Hester 1976:70-71, Fig. 24). The latter type is apparently the most common, and is generally found in Late Archaic or later contexts (Sorrow, Shafer, and Ross 1967:118; Fox, Bass, and Hester 1976:70-71; Fox 1979:58). Martin (1930:Plate 2, No. 2) reports similar pendants in a burial associated with arrow points in Nueces County. Dimensions: ML: 3.1-0.9; MW: 1.6-1.0; MT: 0.2-0.1. Provenience: see Appendix III.

Notched Mussel Shell

A notched mussel shell has an indeterminate number of small notches spaced a few millimeters apart along the ventral margin of the shell (Fig. 29,c). The specimen is highly fragmented and has been preserved in its matrix with gelva. Approximate dimensions: ML: 6.3, MW: 4.6. Provenience: E1013 N1001, 98.50-98.40.

Unidentifiable Unmodified Mussel Shell

Fragments and traces of mussel shell were collected over a wide range of elevations and within every excavated area of the site.

Crustacean Fragment

A small fragment of a crustacean is identified as the claw. The fragment was found directly associated with Burial 8.

\section{MODIFIED BONE}

Thirteen specimens of modified bone have been smoothed or shaped purposefully for specific tasks or functions. Identified types of modified bone are awls, beads, and other bone pieces.

\section{Bone Awls}

Awls are made from long bone splinters, tapered to a point at one end. Both specimens (Fig. 32,a,b) are made from long bone splinters, possibly a deer metatarsal. Only one specimen is nearly complete. One end of this specimen is pointed, and the other end has portions of the articulating epiphysis. Both specimens have been smoothed and polished. The context of Specimen 1 suggests that it may have functioned as a hairpin. Mallouf and Zavaleta (1979:21) have suggested a somewhat similar specimen from the Unland site is a hairpin fashioned out of a human long bone. The two specimens are similar to Hall's (1981) Pointed Bone Form Two. A similar specimen has been reported from Bexar County (Gerstle, Kelly, and Assad 1978:36). Dimensions: Specimen 1: ML: 21.0, MW: 2.8, MT: 0.3; Specimen 2: ML: (8.9), MW: 2.5, MT: 0.4. Provenience: Burial 2, Trenches 17 and 18. 


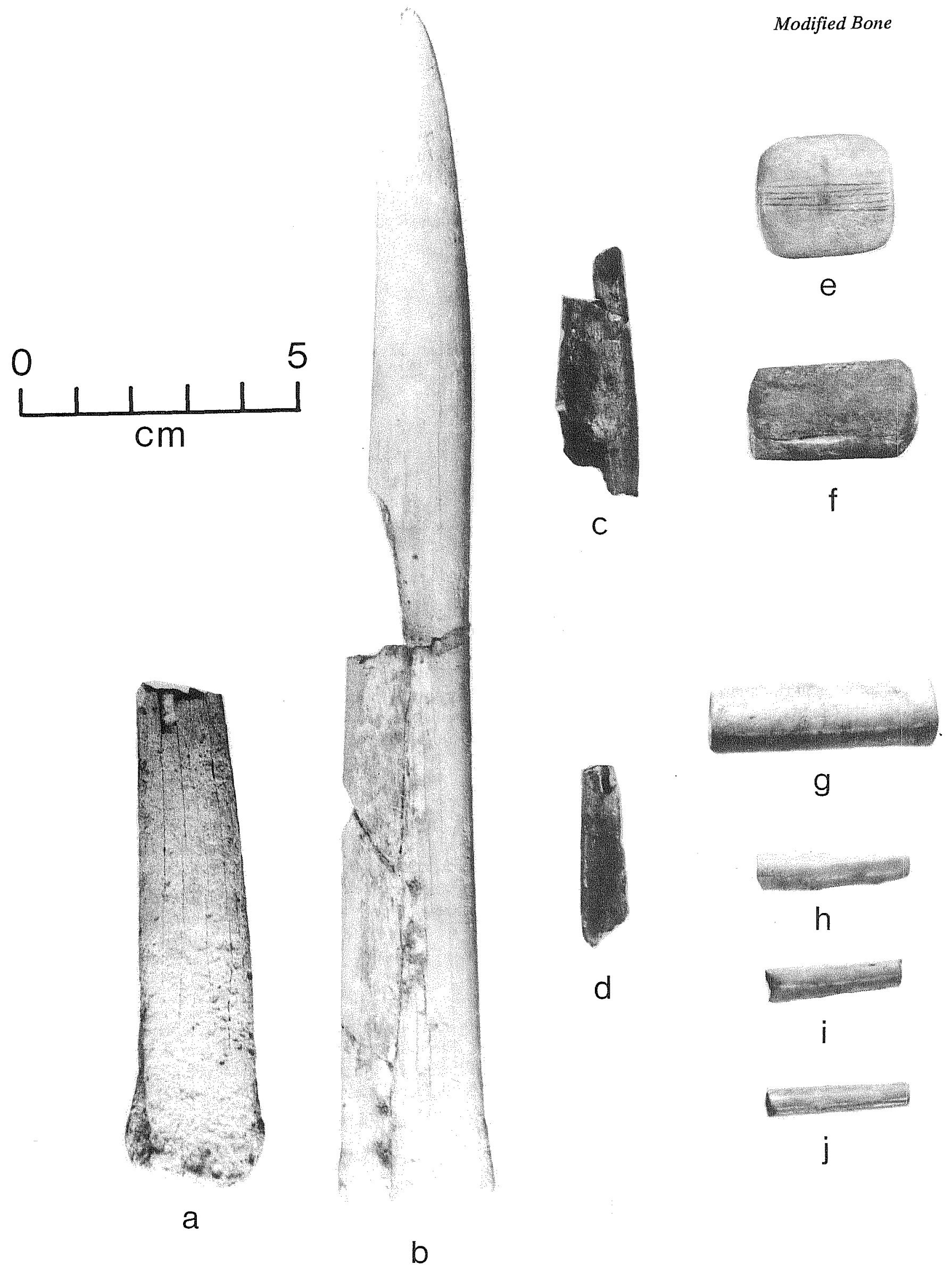

Figure 32. Bone Artifacts from $41 B X 1$. a,b, bone awls; c, ulna tool fragment; d, awl fragment; e,f, rectangular bone pieces; g, bone bead, Form 2 ; $h-j$, bone bead, Form 1. 


\section{Ulna Tool Fragment}

A proximal fragment of a slightly burned ulna, possibly from a deer, appears polished, and has scratch marks visible on the left proximal portion of the bone (Fig. 32,c). Both the articulating proximal and distal (assumed to have been pointed) ends are missing. Similar specimens have been reported by Aten et al. (1976), Henderson (1978), Hester (1971), and Jelks (1962). Dimensions: ML: (4.4), MW: (1.6), MT (distal end): 0.3. Provenience: E1022 N1065, 99.30-99.20.

\section{Awl Fragment}

A well-polished sliver of long bone tapered towards one end is possibly a midsection of a narrow pointed bone awl (Fig. 32,d). Dimensions: ML: (3.1), MW: (0.9), MT: (0.3). Provenience: E1014 N1002, 98.70-98.60.

\section{Bone Beads}

Tubular sections of bone were made by cutting and shaping of long bone shaft sections, followed by smoothing and polishing. Seven specimens were collected. Two forms, based primarily on size, are described.

\section{Form 1}

Six small, thin-walled and fragile bone tubes, possibly are made from bird bones. The ends of the long bone sections are ragged, but some smoothing is indicated. The specimens (Fig. 32,h-j) are consistently about $2.5 \mathrm{~cm}$ in length, with an average maximum diameter of about $0.6 \mathrm{~cm}$. Shaft walls are consistently under one millimeter in thickness. Similar specimens have been reported by Hall (1981). The dimensions for four of the specimens are: ML: 2.8-2.1, MD: 0.7-0.5. Provenience: E1015 N1001, 98.66-98.60; E1014 N1002, 98.70-98.60; Burial 2 (4).

\section{Form 2}

A bone tube (Fig. 32,g) from a long bone section is possibly of a small mammal. Generally the specimen is larger and sturdier than the Form 1 specimens. No references to similar forms could be found. The piece is well made; the cut ends smoothed until almost flat, and the exterior is polished. Minimum shaft wall thickness is $0.2 \mathrm{~cm}$. Dimensions: ML: 4.0, MD: 1.3. Provenience: Area A surface.

\section{Rectangular Bone Pieces}

Two rectangular bone pieces (Fig. 32,e,f) are cut from sections of long bone and have beveled ends. One specimen has five incised lines on the dorsal surface. The lines are approximately one millimeter in width and extend parallel to each other down the long axis of the specimen. Similar specimens have been reported at burial sites by Aten et al. (1976) and Hall (1981:Fig. 20, Rectangular Bone Forms 1 and 2). Dimensions: Specimen 1: ML: 2.2, MW: 2.0, MT: 0.3; Specimen 2: ML: 3.0, MW: 1.7, MT: 0.4. Provenience: Area A surface; E1010 N1000, 98.50-98.40. 


\section{DISCUSSION}

The discussion outlines the horizontal and vertical patterns of artifact and debitage distributions at the site, and the temporal parameters based on the recorded data. A chronological sequence for the site is developed through analysis of the vertical distribution of projectile points and radiocarbon dates. The distribution of artifacts and debitage is summarized to demonstrate patterns that may reflect differing functions of the site components through time. In addition, a brief discussion of the temporal placement, and burial traits recorded at the site is presented.

\section{SITE CHRONOLOGY}

Of the 67 projectile points recovered from $41 \mathrm{BX} 1,42$ specimens were from the excavations within Zone 2 of Area A, 10 specimens were from Zone 2 of Area B, and seven specimens were from Zone 3. The remaining eight specimens were surface collected. Utilizing projectile point sequences and the seven radiocarbon dates available from the site, a chronological sequence is presented for the site.

The vertical distribution of projectile points from Zone 2 of Area A suggests considerable mixing of prehistoric components has occurred, especially in the upper elevations. At elevations of 98.20 and above, 26 projectile points were recvovered, and of these, 14 can be classified as Transitional or Late Archaic types: Frio (four), an Ensor, Fairland (three), a Marshall, a Montell, and Castroville (four). Five of the 26 specimens can be classified as Middle to Early Archaic types: Pedernales (three), a Bulverde, and a La Jita. Below an elevation of 98.20 , a total of 16 projectile points was recovered; and of these, seven specimens were identified as Middle Archaic or earlier forms: a Pedernales, Nolan (three), an Early Corner Notched point, a Bell, and an Angostura; and three specimens were Late Archaic forms: Montell (two) and a Frio. While no clear vertical sequence of point types can be discerned, the collection does indicate that the upper deposits probably date between the Transitional and Late Archaic periods (ca. 2600 to 1250 B.P.), and the lower deposits probably are Middle Archaic or earlier in age (ca. 5000 to 2600 B.P.).

\section{ZONE 2 OF AREA A}

The only projectile point that was clearly associated with a burial could not be identified as a commonly recognized type (classified as Miscellaneous Form 4). The point has some typological similarities to the Godley type, a small side-notched form that is characteristic of Late Archaic (Twin Sisters phase) dart points (Weir 1976a).

Three radiocarbon dates were obtained from the Area A excavations; two are from contexts associated with the lower levels of soil zone 2, and the other is from within soil zone 3. The radiocarbon dates from Area A support the overall indications of the projectile point sequence as previously discussed. The two radiocarbon dates from soil zone 2 are 2350 to 2080 B.P. (TX-3989) and 2050 to 1690 B.P (TX-3993), indicating a Late Archaic association for many of the diagnostic forms recovered from soil zone 2 . The radiocarbon sample (TX-3990) from soil zone 3 has a Middle Archaic Round Rock phase date (3630 to 3410 B.P.). This date is significant here because of its location at the approximate elevation where Middle Archaic and earlier diagnostics begin to dominate the collection.

\section{ZONE 2 OF AREA B}

During the excavation of Zone 2 in Area B, a total of 10 projectile points was recovered from Unit E1029 $\mathrm{N} 1001$. While few in number, the vertical distribution of these 10 projectile points seems more in line with what would be a commonly expected sequence of Archaic types. Transitional or Late Archaic forms (an Ensor and a Frio) were confined to soil zone 2A between approximately 99.30 and 99.10 in elevation. In soil zones $2 \mathrm{~B}$ and 2C, between 99.10 and 98.70 , the six recovered dart points include a Late Archaic Lange, two Middle Archaic Pedernales types, and one specimen each of a Miscellaneous Form 1 and a Miscellaneous 
Form 6. Two projectile points were recovered from the midden zone soils, a Travis and an Early Corner Notched type. No projectile points were recovered from below the midden zone.

The two radiocarbon dates from Area B were taken from contexts at the top and $30 \mathrm{~cm}$ below the burned rock midden. Both dates fall within the Middle Archaic (Clear Fork phase). TX-3799 (4750 to 4490 B.P.) was taken from the top of the midden, and TX-3991 (5100 to 4830 B.P.) was taken from below the midden. Given the occurrence of only Clear Fork diagnostics between the elevations that the radiocarbon samples were taken from, the burned rock midden and deposits directly below the midden are assigned to the Clear Fork phase.

\section{ZONE 3}

Seven projectile points were recovered from Zone 3. Four specimens were from soil zone 2. Of these four, one could not be typed or dated, and the other three, an Ensor and two Frios, are Late Archaic (Twin Sisters phase) diagnostics. Below an elevation of 98.10, two Kinney types and a Miscellaneous Form 2 specimen were recovered. The radiocarbon sample (TX-3992: 4410 to 3640 B.P.) from the Zone 3 excavations was taken from the unit level between the two Kinney forms, and suggests that the point type and the associated deposits of soil zone 3 date to the early part of the Round Rock phase or the later half of the Clear Fork phase of the Middle Archaic.

\section{SUMMARY OF CHRONOLOGY}

The distribution of projectile point types considered diagnostic of the Archaic, associated with specific soil zones recognized across all site areas, and a series of radiocarbon dates have been used to define the chronological sequence at $41 \mathrm{BX} 1$. Fourteen of the 19 typed points recovered from soil zone 2 are identified as Late Archaic forms (Frio, Ensor, Fairland, Castroville, Montell, and Lange), while the remaining five are identified as Middle Archaic Round Rock forms (Pedernales, Langtry, Bulverde). The two radiocarbon dates from soil zone 2 are between 2350 and 1690 B.P., placing it within the San Marcos phase and early part of the Twin Sisters phase of the Late Archaic. Within soil zone 3, only Middle Archaic diagnostics were recovered outside of the horizontally distinct Zone 2 of Area $A$, and the three radiocarbon dates for this soil zone are between 5100 and 3640 B.P. Within Zone 2 of Area A, soil zone 3 contained predominately Middle Archaic diagnostics and a Middle Archaic radiocarbon date; however, considerable mixing of cultural materials has occurred due to disturbances rclated to the area's use as a cemetery.

\section{ARTIFACT DISTRIBUTIONS}

No definite patterns of distribution were observed for the artifacts recovered from the site. However, chipped stone tools were slightly more common in the soil zone 2 matrix. The following paragraphs summarize the distribution of the lithic tools.

A total of 76 thin bifaces was recovered from the site; 10 specimens have a convex base, five specimcns have a concave base, and five specimens have a straight base. The remaining specimens include 26 pointed fragments, six midsections, and 24 miscellaneous or edge fragments. The majority of the thin bifaces were found during excavations of Zone 2 in Area A (50 specimens). Thirteen specimens were recovered from Zone 2 of the Area B excavations, and five specimens were recovered from the Zone 3 excavations. Six of the 76 thin bifaces were collected from the surface.

None of the thin biface categories indicate discrete vertical or horizontal segregations. Most of the thin bifaces were scattered throughout the site; the only unusual distribution was noted from Zone 3 -no basal fragments were identified. 
Thin bifaces were most common between elevations of 98.60 and 98.30 (28 of 51 specimens) near the boundary of soil zones 2 and 3 in Zone 2 of Area A. In Unit E1029 N1001 in Zone 2 of Area B, the most frequent occurrence of thin bifaces (eight of 13 specimens) was between elevations of 99.30 and 99.00 . In Zone 3, the five specimens recovered were scattered throughout the nine unit-levels.

Thick bifaces were less frequent at the site than thin bifaces. Of the 19 specimens recovered, 12 specimens were from Zone 2 in Area A, three specimens were from Zone 2 in Area B, two specimens were from Zone 3 , and two specimens were collected from the surface. Within Zone 2 of Area A, four thick bifaces were recovered between 98.50 and 98.40. In Zone 2 of Area B, all three miscellaneous fragments were recovered between 99.20 and 98.80 , above the midden zone. In Zone 3 , the three thick biface specimens were scattered throughout the nine unit-levels.

A total of 54 retouched flakes and 28 retouched chips was recovered from the site. Combining the two categories, a total of 26 retouched specimens was recovered from Zone 2 of Area A, and the majority of these (15 of the 26) were recovered from between elevations of 98.50 and 98.20 . In Zone 2 of Area B, the 10 retouched flakes and chips were scattered throughout Unit E1029 N1001, and with one exception, when three spccimens were recovered from between 99.00 and 98.90 , there was never more than one specimen recorded for any unit-level. From Zone 3, 15 retouched flakes and chips were recovered, and two-thirds of these were recovered from soil zone 2 contexts between 99.50 and 99.20. Only five retouched flakes and chips were found on the surface at the site.

Combining the modified flakes and chips, a total of 96 specimens was recovered. Seventy-one specimens were recovered from Zone 2 of Area A, and 49 specimens were located between 98.40 and 98.10. In Zone 2 of Area B, only six modified flakes and chips were recovered, all scattered throughout the 22 levels of Unit E1029 N1001. In Zone 3, the majority of the 18 modified flakes and chips recovered were from between 99.50 and 99.20 ( 15 of the 18 specimens).

Ground stone and modified quartz cobbles were not common at the site. Of the six grinding slab fragments recovered, three were surface finds, and the remaining three specimens were recovered from the excavations in Zone 2 of Area A. One grinding slab fragment was a grave inclusion associated with Burial 2. Of the three handstones recovered, one was a surface find, and two specimens were recovered from excavations in Zone 2 of Area B. Modified quartz cobbles were confined to Zone 2 of Area A.

\section{DEBITAGE DISTRIBUTIONS}

The distribution of debitage provides some indication of the variation and intensity of occupation within the site. In conjunction with the chronological sequence outlined earlier in this section, the distribution of debitage suggests repeated use of an intense nature at the site over periods of time, separated by periods when occupation was relatively infrequent.

Due to the varying amounts of excavation carried out in the three site areas investigated during the project, and in order to make meaningful intersite comparisons between these areas, it was necessary to create equal sized units of measurement between the excavation areas. This was accomplished by summing the total number of flakes and chips within the three excavation areas (Zone 2 of Areas A and B, and Zone 3) between $10 \mathrm{~cm}$ increment elevation points (levels) and dividing the "level" by the number of square meters excavated within each area; thus an average number of debitage specimens in a one by one square meter unit level could be estimated for each excavation area. The resulting estimates of debitage counts for the three excavation areas are shown in Figure 33.

Within Zone 2 of Area A, the vertical distribution of debitage is characterized by low counts above elevations of 98.70; the counts range from 9 to 25 items in any level. Below an elevation of 98.70 , the number of items per level increases greatly, ranging between 29 and 54 items. The increase in debitage below 98.70 reflects the elevation at which systematic recovery (screening) of materials was begun. While the distribution of debitage below 98.70 appears relatively consistent from level to level, there is some indication of slightly 
greater debitage counts between the elevations of 98.60 and 98.40 and again at 97.90 and 97.80 . These two slight peaks in the vertical distribution occur at points in the soil profile where there are soil zone boundaries; the first at the approximate contact between soil zones 2 and 3, the second within soil zone 3 and just above soil zone 4. Given the distribution of diagnostic projectile point types and the radiocarbon dates from Area $A$, the two peaks are interpreted as representing the vertical locations of the most intense Late Archaic (the upper peak) and Early Archaic to Middle Archaic (the lower peak) occupations.

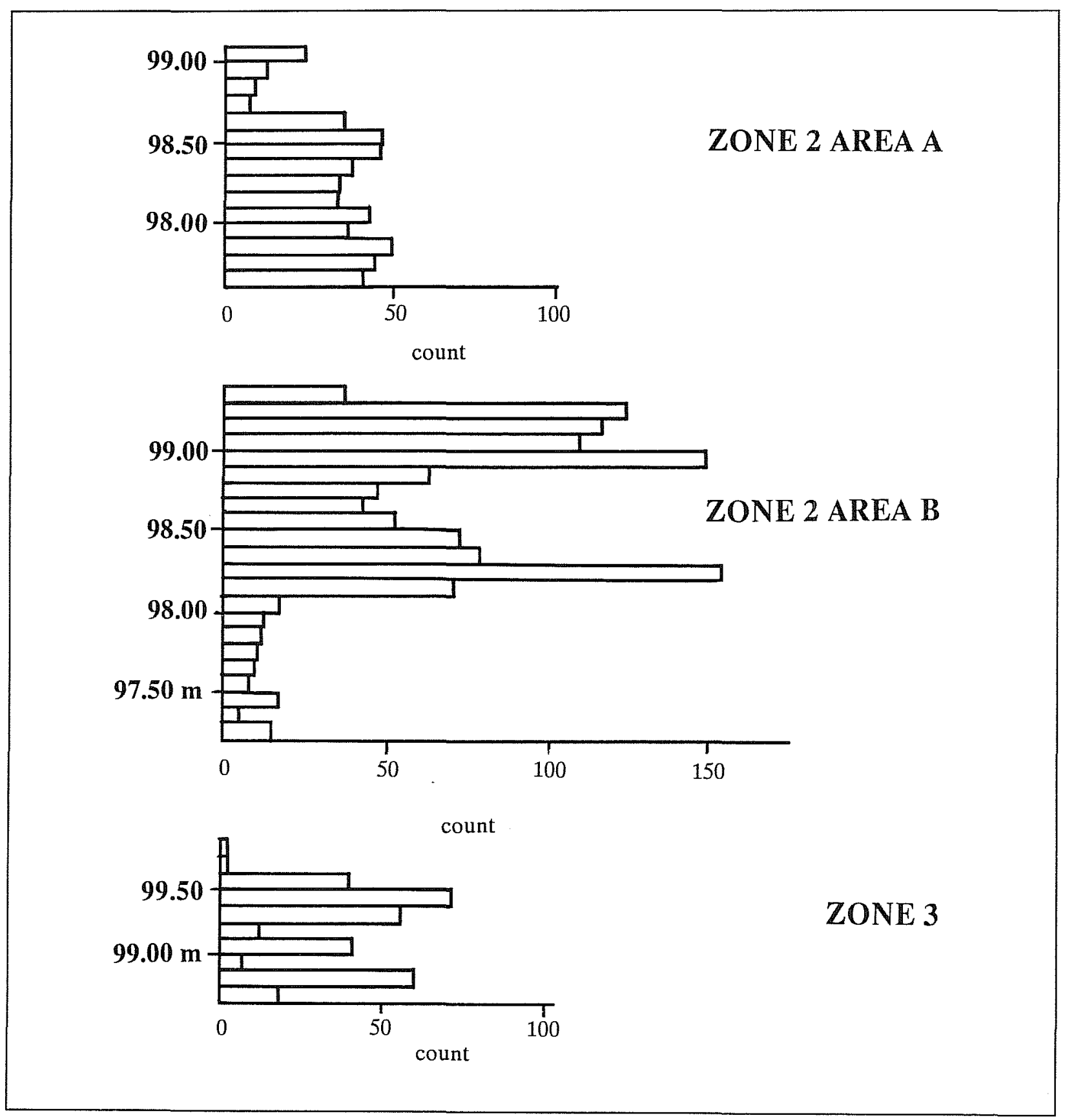

Figure 33. Bar Graph of Flake and Chip Estimates by Excavation Area. 
Within Zone 2 of Area B, the distribution of flakes indicates three areas within the profile where the greatest debitage counts occur: the uppermost at elevations between 99.30 and 99.20 , another at 99.00 to 98.90 , and the deepest between 98.30 and 98.20 . Relatively lower debitage counts occur just above and within the burned rock midden zone. Below an elevation of 98.00 , as soil zone 4 is entered, the debitage counts drop off greatly, suggesting very little cultural activity.

The threc peaks can be related to the soil profile, diagnostic projectile points, and radiocarbon dates from Area $B$, and can locate differing occupations within the area. The uppermost peak is contained within soil zone $2 \mathrm{~A}$, and is associated with Late Archaic Twin Sisters phase diagnostics. The second peak is contained within soil zone $2 \mathrm{~B}$ and is associated with Late Archaic and Middle Archaic Round Rock diagnostics. The lowest peak occurs within soil zone 3 just above soil zone 4; although no diagnostic projectile points were found within the lower levels, the occurrence of Early and Middle Archaic diagnostics in the burned rock midden above it, and radiocarbon dates from within soil zone 3 suggest that the peak represents an Early to Middle Archaic component.

Within Zone 3, debitage counts are highest between the elevations of 99.40 and 99.20 , which corresponds to soil zone 2B and is associated with Late Archaic (Twin Sisters) diagnostics. Lower in the profile, within soil zone 3 and between the elevations of 99.10 and 99.00 and 98.90 and 98.80 , there are two dramatic rises in the debitage counts; both of these increases are associated with the Kinney type, a Middle Archaic diagnostic. A radiocarbon sample between the two debitage peaks within soil zone 3 suggests a date within the early part of the Round Rock phase or the later half of the Clear Fork phase.

\section{ASPECTS OF THE BURIAL COMPONENT}

In Zone 2 of Area A, the burial component occurs from 98.90 to 97.90 (see Fig. 34). The highest burials are those of infants: Burials 7,8, and 9. Discounting these three burials, Figure 34 shows that most of the burials have a minimum origin point of about 98.55 , and most of the burials do not extend below 98.10 , indicating an overall range of about $1 \mathrm{~m}$ for all of the burials, but with the general trend to about $50 \mathrm{~cm}$. The minimum range of origin points for all of the burials falls between 98.88 (Burials 8 and 9) and 98.25 (Burial 5); these ranges, considered in conjunction with the two radiocarbon samples (TX-3989 and TX-3993) taken between 98.70 and 98.60 and a radiocarbon sample taken from a burned rock scatter at 98.20 (and intruded upon by Burial 10), limit the probable dates of the burials to between $3310 \pm 110$ B.P. and $1920 \pm 160$ B.P. These data suggest that the burials are Late Archaic in age.

The burial mode for the site was flexed, primary interments. Orientation of the burials towards any cardinal direction was most commonly to the north-northeast, although some individual burials were recorded with north-northwest and south-southeast orientation. Age ranges for the individuals were from newborn to mature adults. Grave accompaniments were antler (occurring in seven of the 13 burials), worked mussel shell (six of the 13 burials), and large chert cobbles (three of the 13 burials). Worked bone, chipped stone artifacts, and ground stone were the least common inclusions. Ocher, although not recorded as a grave good, occurred in eight of the 13 burials. 


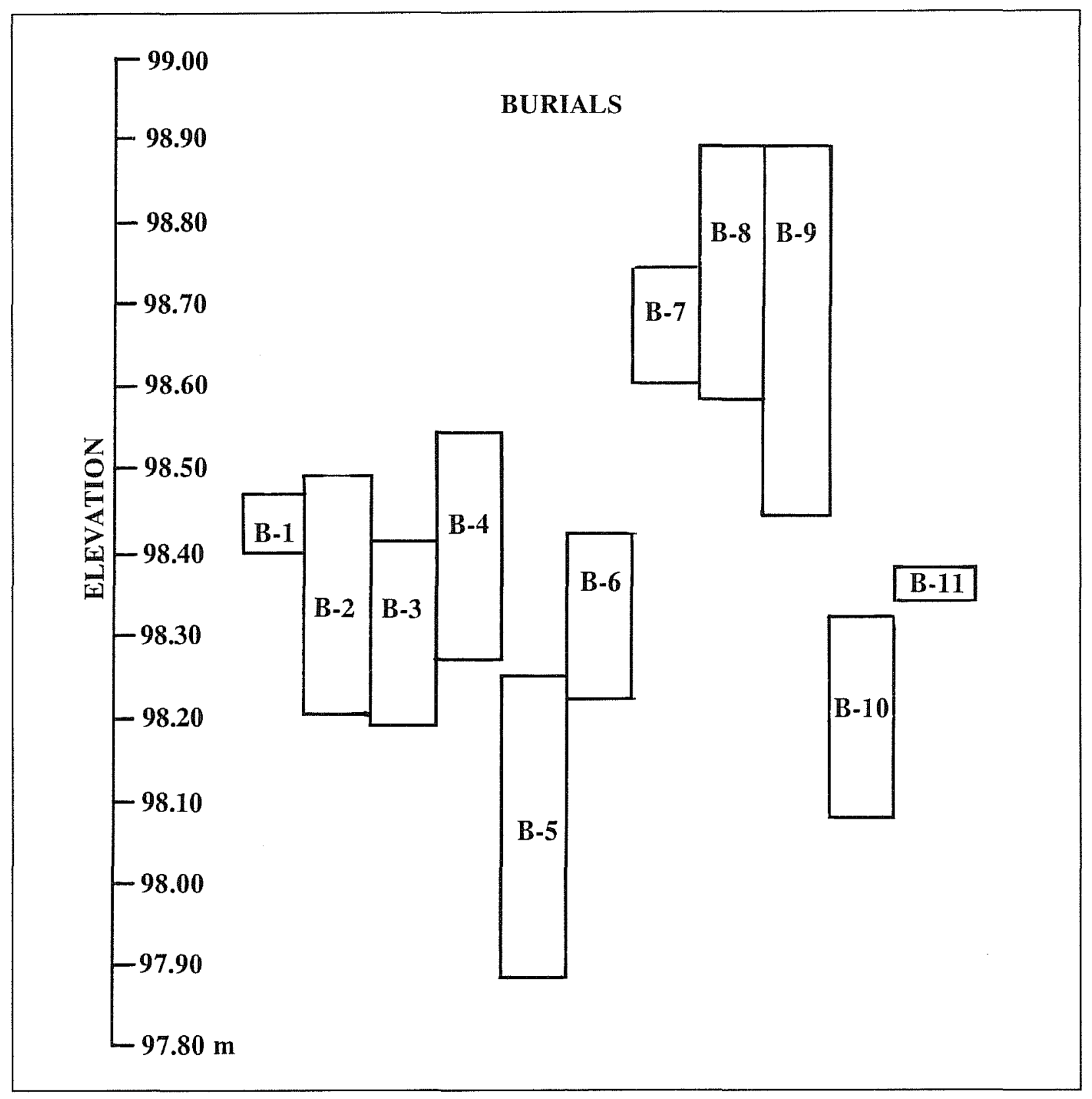

Figure 34. Vertical Distribution Limits of Burials. 


\section{SUMMARY}

Based primarily upon the results of test trenching operations by Kelly and Eaton (1979) and the documentation of $i n$ situ burials by the UTSA Summer Field School during 1979, discrete areas of significant archaeological remains discovered during construction activities related to renovation work on the Olmos Dam, were defined, and protection measures were initiated. During late 1979 and early 1980, excavations were carried out at the site by the CAR-UTSA as part of this plan at the request of the San Antonio River Authority.

These excavations were directed towards three specific areas within the site: Zone 2 of Area A, Zone 2 of Area $\mathrm{B}$, and Zone 3. The excavations were intended to document as much information as possible within given time and funding limitations; the ultimate disposition of the site was to be later determined through approved cultural resource management (Kelly and Eaton 1979:9).

Block excavations of a $36-\mathrm{m}^{2}$ area within Zone 2 of Area A resulted in the documentation of a burial component from which 13 burial features were removed. Additionally, a number of cultural features and occupational debris from soil deposits over $1.5 \mathrm{~m}$ deep were recorded. The burials, identified as a Late Archaic component, were associated with two radiocarbon dates of 1920 B.P. and 2200 B.P. The burial practices of this time period as documented at this site include flexed burials of adults and children interred with a variety of grave offerings, including deer antlers, deer skull fragments, marine and freshwater shell ornaments, worked bone, ocher, a ground stone slab, and unaltered cobbles. There appears to be a wide range of ritual treatments for the small number of individuals in the burial component as indicated by the amount and variety of grave offerings and body placements. Evidence of one violent death from a projectile point was also recorded. Other materials recovered from Zone 2 of Area A indicate that there was some cultural activity in this location throughout the span of the Archaic period (such as projectile points from the Early, Middle, and Late Archaic). The only Paleo-Indian point form (Angostura) recovered from the site during the excavations was located in Area A.

Limited excavations in Zone 2 of Area B revealed approximately $1.5 \mathrm{~m}$ of deposits with relatively intensive occupation; however, some cultural material was present to a depth of over two meters. The vertical distribution of the lithic artifacts and the soil profiles further suggest variations in the intensity of prehistoric activity over time. Possible chronological distinctions related to the Late Archaic, Middle Archaic, and Early Archaic can be associated with the most "active" areas. A burned rock midden feature, radiocarbon dated 4380-4110 B.P., was recorded within Area B; these dates are the earliest recorded from the site.

Limited excavations in Zone 3 document a Late Archaic occupation characterized by relatively high lithic counts; below this occupation are indications of an earlicr, possibly Middle Archaic, activity zone radiocarbon dated 3710 B.P.

The work carried out during the course of this project has provided valuable descriptive data on the people and burial practices of the Late Archaic period in south-central Texas. It has also documented information relevant to the understanding of the nature and extent of occupational deposits within specific areas of site $41 \mathrm{BX} 1$. 


\section{REFERENCES CITED}

Andrews, J.

1971 Sea Shells of the Texas Coast. University of Texas Press, Austin.

Arbingast, S. A., L. G. Kennamer, R. H. Ryan, J. R. Buchanan, W. L. Hezlep, L. T. Ellis, T. G. Jordan, C. T. Granger, and C. P. Zlatkovich

1976 Atlas of Texas. Bureau of Business Research, The University of Texas at Austin.

Assad, C. A.

1978 Archaeological Testing in an Area South of Olmos Dam, San Antonio, Texas. Center for Archaeological Research, The University of Texas at San Antonio, Archaeological Survey Report 54.

1979 Archaeological Testing in the Devine Road Area North of O1mos Dam, San Antonio, Texas. Center for Archaeological Research, The University of Texas at San Antonio, Archaeological Survey Report 53.

Aten, L. E., C. K. Chandler, A. B. Wesolowsky, and R. M. Malina

1976 Excavations at the Harris County Boys' School Cemetery. Texas Archeological Society, Special Publication 3.

Barnes, V. E.

1974 Geological Atlas of Texas. San Antonio Sheet. Robert Hamilton Cuyler Memorial Edition. Bureau of Economic Geology, The University of Texas at Austin.

Bass, W. M.

1971 Human Osteology: A Laboratory and Field Manual of the Human Skeleton. University of Missouri, Columbia.

Black, S. L. and A. J. McGraw

1985 The Panther Springs Creek Site: Cultural Change and Continuity Within the Upper Salado Creek Watershed, South-Central Texas. Center for Archaeological Research, The University of Texas at San Antonio, Archaeological Survey Report 100.

Blair, W. F.

1950 The Biotic Provinces of Texas. The Texas Journal of Science 2(1):93-116.

Brothwell, D. R.

1972 Digging Up Bones, The Excavation, Treatment, and Study of Human Skeletal Remains. 2nd edition. British Museum of Natural History, London. 
Brown, D.

1977 An Archaeological Survey of Proposed Areas for Alternate Roadways at Olmos Dam, San Antonio, Texas. Center for Archaeological Research, The University of Texas at San Antonio, Archaeological Survey Report 37.

Calhoun, C. A.

n.d. Letter to Anne Fox on horse conch shells in Bell County. On file at the Center for Archaeological Research, The University of Texas at San Antonio.

Campbell, T. N.

1952 The Kent-Crane Site: A Shell Midden on the Texas Coast. Bulletin of the Texas Archeological and Paleontological Society 23:39-77.

1976 Archaeological Investigations at the Morhiss Site, Victoria County, Texas, 1932-1940. In An Archaeological Survey of Coleto Creek, Victoria and Goliad Counties, Texas, by A. A. Fox and T. R. Hester:81-85. Center for Archaeological Research, The University of Texas at San Antonio, Archaeological Survey Report 18.

Caras, R. A.

1967 North American Mammals. Sulahad Books, New York.

Corps of Engineers

1972 Floodplain Information Olmos Creek San Antonio, Texas. Report prepared by the Department of the Army, Corps of Engineers, Fort Worth District.

Crabtree, D. E.

1972 An Introduction to Flintworking. Idaho State University, Occasional Papers of the Museum 28.

Dasmann, W.

1971 If Deer Are To Survive. Stackpole Books, Harrisburg, Pennsylvania.

Fawcett, W., Jr.

1972 The Prehistory of Bexar County: A Study of Previous Work in South Central Texas. Lower Plains Archaeological Society Bulletin 2:23-43.

Fox, A. A.

1975 An Archaeological Assessment of the Southern Portions of the Olmos Basin, Bexar County, Texas. Center for Archaeological Research, The University of Texas at San Antonio, Archaeological Survey Report 9.

Fox, A. A., F. A. Bass, Jr., and T. R. Hester

1976 The Archaeology and History of Alamo Plaza. Center for Archaeological Research, The University of Texas at San Antonio, Archaeological Survey Report 16. 
Fox, D. E.

1979 Archaeological Investigations of Two Prehistoric Sites on the Coleto Creek Drainage, Goliad County, Texas. Center for Archaeological Research, The University of Texas at San Antonio, Archaeological Survey Report 69.

French, D.

1980 Letter from Dorian French (Chief Engineer, San Antonio River Authority) dated April 1, 1980. On file at the Center for Archaeological Research, The University of Texas at San Antonio.

Gerstle, A., T. C. Kelly, and C. Assad

1978 The Fort Sam Houston Project: An Archaeological and Historical Assessment. Center for Archaeological Research, The University of Texas at San Antonio, Archaeological Survey Report 40.

Gould, F. W.

1969 Texas Plants: A Checklist and Ecological Summary. Texas A\&M University, Texas Agricultural Experiment Station, Publication MP-585, Revised.

Greer, J. W.

1977 A Columella Bead from the San Antonio Area of South Central Texas. La Tierra 4(2):17-19.

Hall, G. D.

1981 Allens Creek: A Study in the Cultural Prehistory of the Lower Brazos River Valley, Texas. Texas Archeological Survey, The University of Texas at Austin, Research Report 61.

Henderson, $\mathrm{J}$.

1978 Faunal Analysis of Site 41 BX 36, with Data Presented for 41 BX 377 and 41 BX 428 . In The Fort Sam Houston Project: An Archaeological and Historical Assessment, by A. Gerstle, T. C. Kelly, and C. Assad:229-252. Center for Archaeological Research, The University of Texas at San Antonio, Archaeological Survey Report 40.

1980 Update on Excavations near the Intersection of I-10 and FM-1604. Paper presented to the Southern Texas Archaeological Association, January 19, 1980.

Hester, T. R.

1969 The Floyd Morris and Ayala Sites: A Discussion of Burial Practices in the Rio Grande Valley and the Lower Texas Coast. Bulletin of the Texas Archeological Society 40:157-166.

1971 Archaeological Investigations at the La Jita Site, Uvalde County, Texas. Bulletin of the Texas Archeological Society 42:51-148.

1975a Archaeological and Historical Resources in the San Antonio-Guadalupe River Basins: A Preliminary Statement. Center for Archaeological Research, The University of Texas at San Antonio, Regional Studies 1. 
Hester, T. R. (continued)

1975b Notes on the Collier Collection from the Southern Olmos Basin. Appendix in An Archaeological Assessment of the Southern Portions of the Olmos Basin, Bexar County, Texas, by A. A. Fox:19-21. Center for Archaeological Research, The University of Texas at San Antonio, Archaeological Survey Report 9.

1977 The Current Status of Paleoindian Studies in Southern Texas and Northeastern Mexico. In The Museum Journal XVII, edited by E. Johnson. West Texas Museum Association, Texas Tech University, Lubbock.

1978 Early Human Occupations in South Central and Southwestern Texas: Preliminary Papers on the Baker Cave and St. Mary's Hall Sites. Center for Archaeological Research, The University of Texas at San Antonio.

1979 Early Populations in Prehistoric Texas. Archaeology 32(6):26-33.

1980 Digging Into South Texas Prehistory. Corona Publishing Company, San Antonio, Texas.

n.d. Technological Study of Prehistoric Shell Implements in the Circum-Carribean and Gulf Coast of Mexico Regions. Paper on file at the Center for Archaeological Research, The University of Texas at San Antonio.

Hudgeons, M. D. and T. R. Hester

1977 An Aboriginal Burial at the Dunn Site, DeWitt County, Southern Texas. La Tierra $4(3): 10-14$.

Inglis, J. M.

1964 A History of Vegetation on the Rio Grande Plain. Texas Parks and Wildlife Bulletin 45.

Jelks, E. B.

1962 A Stratified Central Texas Aspect Site in Hill County, Texas. Department of Anthropology, The University of Texas at Austin, Archaeology Series 5.

Johnson, L., Jr.

1964 The Devil's Mouth Site, A Stratified Campsite at Amistad Reservoir, Val Verde County, Texas. Department of Anthropology, The University of Texas at Austin, Archaeology Series 6:1-115.

Katz, P. R.

1987 Archaeological Mitigation at 41 BX 300, Salado Creek Watershed, South-Central Texas. Center for Archaeological Research, The University of Texas at San Antonio, Archaeological Survey Report 130.

Katz, S. R.

ms. Excavations at Sites 41 BX 24 and 41 BX 291, San Antonio, Texas. Manuscript on file at Incarnate Word College, San Antonio, Texas. 
Katz, S. R. and A. A. Fox

1979 Archaeological and Historical Assessment of Brackenridge Park, City of San Antonio, Texas. Center for Archaeological Research, The University of Texas at San Antonio, Archaeological Survey Report 33.

Kelley, J. C.

1947 The Lehmann Rock Shelter: A Stratified Site of the Toyah, Uvalde, and Round Rock Foci. Bulletin of the Texas Archeological and Paleontological Society 18:115-128.

Kelly, T. C. and J. D. Eaton

1979 Additional Archaeological Investigations at Site 41 BX 1, North of Olmos Dam, Bexar County, Texas. Center for Archaeological Research, The University of Texas at San Antonio, Archaeological Survey Report 86.

Luke, C.

1974 Archaeological Investigations Along the Route of U.S. 281 from Mulberry Ave. to Tuxedo Ave., in San Antonio, Texas. State Department of Highways and Public Transportation. On file at the Center for Archaeological Research, The University of Texas at San Antonio.

Mallouf, R. J. and A. Zavaleta

1979 The Upland Site: A Prehistoric Group Burial from Laguna Atascosa National Wildlife Refuge, Cameron County, Texas. Texas Historical Commission, Office of the State Archeologist, Special Report 25.

Martin, G. C.

1930 Two Sites on the Calle Del Oso, Nueces County, Texas. Bulletin of the Texas Archeological and Paleontological Society 2.

Montgomery, J. L.

1978 The Mariposa Site: A Late Prehistoric Site on the Rio Grande Plain of Texas. Volume 2. Studies in the Archaeology of the Chaparrosa Ranch. Center for Archaeological Research, The University of Texas at San Antonio, Special Report 6.

Orchard, C. D. and T. N. Campbell

1954 Evidences of Early Man from the Vicinity of San Antonio, Texas. The Texas Journal of Science 6(4).

1960 Southwestern Pottery Sites in the Vicinity of San Antonio, Texas. Texas Archeology 4(2):7-8.

Prewitt, E. R.

1974 Archaeological Investigations at the Loeve-Fox Site, Williamson County, Texas. Texas Archeological Survey, The University of Texas at Austin, Research Report 49. 
Ralph, E. K., H. N. Michael, and M. C. Han

1973 Radiocarbon Dates and Reality. Applied Science Center for Archeology, MASCA Newsletter 9(1):1-20.

Sellards, E. H. and C. L. Baker

1934 The Geology of Texas. Vol. II: Structural and Economic Geology. The University of Texas Bulletin 3401.

Shafer, H. J.

1963 Test Excavations at the Youngsport Site: A Stratified Terrace Site in Bell County, Texas. Bulletin of the Texas Archeological Society 34:57-81.

1976 Defining the Archaic: An Example from the Lower Pecos Area of Texas. In The Texas Archaic: A Symposium, edited by T. R. Hester:60-66. Center for Archaeological Research, The University of Texas at San Antonio, Special Report 2.

Sollberger, J. B. and T. R. Hester

1972 The Strohacker Site: A Review of Pre-Archaic Manifestations in Texas. Plains Anthropologist 17(58):326-344.

Sorrow, W. M., H. J. Shafer, and R. E. Ross

1967 Excavations at Stillhouse Hollow Reservoir. Papers of the Texas Archeological Salvage Project 11.

Sprague, R.

1968 A Suggested Terminology and Classification for Burial Description. American Antiquity 33(4):479-485.

Story, D. A

1980 Adaptive Strategies of Archaic Cultures of the West Gulf Coastal Plain. Revised version of a paper prepared for an advanced seminar entitled "The Origins of Plant Husbandry in North America." March 3-7, 1980.

Suhm, D. A.

1960 A Review of Central Texas Archeology. Bulletin of the Texas Archeological Society 29.

Suhm, D. A., A. D. Krieger, and E. B. Jelks

1954 An Introductory Handbook of Texas Archeology. Bulletin of the Texas Archeological Society 25.

Suhm, D. A. and E. B. Jelks

1962 Handbook of Texas Archeology: Type Descriptions. Texas Archeological Society, Special Publication 1 and Texas Memorial Museum, Bulletin 4. 
Taylor, F. B., R. B. Hailey, and D. L. Richmond

1966 Soil Survey of Bexar County, Texas. U.S. Department of Agriculture, Soil Conservation Service, Series 1962:12.

Tunnell, C. D.

1962 Oblate: A Rockshelter Site. In Salvage Archeology of Canyon Reservoir: The Wunderlich, Footbridge, and Oblate Sites, by L. Johnson, Jr., D. A. Suhm, and C. D. Tunnell:77-116. Texas Memorial Museum, Bulletin 5.

Ubelaker, D. H.

1978 Human Skeletal Remains: Excavation, Analysis, Interpretation. Aldine Publishing Company, Chicago.

Watts, F.

1936 Ayacok Shelter. Central Texas Archaeological Society 2.

Weir, F. A.

1976a The Central Texas Archaic. Unpublished Ph.D. dissertation, Washington State University, Pullman.

1976b The Central Texas Archaic Reconsidered. In The Texas Archaic: A Symposium, edited by T. R. Hester:60-66. Center for Archaeological Research, The University of Texas at San Antonio, Special Report 2.

1979 Greenhaw: An Archaic Site in Central Texas. Bulletin of the Texas Archeological Society 50:5-68.

Woolford, S. W.

1935 Types of Sites in Bexar County, Texas. Witte Museum, Archaeological Bulletin 4. 


\section{APPENDIX I}

\section{SOIL ANALYSIS}

Seventy soil samples from 41 BX 1 were submitted to Archaeological Services, Inc., of Maryland for analysis of $\mathrm{pH}$ levels and phosphate and potassium content. The data from the analysis are presented in Table 3 and are summarized in Table 4.

The soil samples were taken in $10-\mathrm{cm}$ increments from continuous columns measuring $10 \mathrm{~cm}$ wide, $10 \mathrm{~cm}$ deep, and extending throughout the vertical length of the selected profiles. Samples from Unit E1012 N1002 were taken from the west wall profile of that unit, and similarly the samples from Units E1022 N1065 and E1029 N1001 were taken from the north and east walls, respectively. Each of the columns was located in the approximate center of the profile walls. Soil samples from a number of the site burials and features were also submitted for testing.

Soils with a low soil reaction $(\mathrm{pH})$ are considered acidic and can be expected to contribute to the decomposition of perishable materials such as bone (Gordon and Buikstra 1981). Additionally, highly acidic soils may help to leach phosphates out (Cornwall 1958:195). Organic phosphates are normally introduced into the soil by the dccomposition of organic matter from human and/or animal activity, and concentrations of phosphates within an archaeological site can usually be expected to be the result of human activity (Cornwall 1958:196). Once in place, phosphates migrate very little and are not easily washed out (Goffer 1980:333-334), which would suggest phosphates could be useful in identifying specific activity concentrations within a site. Potassium is introduced into the soil in the same way as organic phosphates are, and has been shown to covary with material culture densities within some sites (Goffer 1980:339). Gunn and Mahula (1977:57-66) suggest potassium content may be increased within a site through wood burning.

At $41 \mathrm{BX} 1$, soil reaction averages 8.3 , and ranges from 8.0 to 8.5 . This would indicate the soil is slightly basic. Within this very narrow range, there is some indication that $\mathrm{pH}$ values increase with depth, and this appears to be associated with an increase in calcareous deposits generally noted in soil zones 4 and 5 .

Phosphates appear to be a relatively sensitive indicator of cultural activity within a site. Phosphate readings were, on the average, higher for the burial and feature samples than for the column samples. Additionally, comparisons of phosphate readings with the overall vertical distribution of lithic debitage within each excavation area showed some degree of co-variation between the two. For example, in Zone 2 of Area A in Unit E1012 N1002, the highest phosphate readings were obtained from the samples lying between 98.50 and 97.70 in elevation; while burials, features, and lithic debitage were most common from about 98.90 to 98.70 . Although the value readings for the column samples were, on the average, lower than the readings for burials and features, the ranges for all these samples overlap, and it would be difficult to identify a burial or feature solely on the amount of phosphate recorded for any provenience.

In Unit E1029 N1001 the value readings from the column sample indicates the highest phosphate levels occurred from elevations between 99.20 and 98.90 , between 98.70 and 98.50 , and between 98.20 and 97.90 . Relatively high debitage counts were recorded from units at corresponding elevations between 99.20 and 98.90 and 98.30 and 98.20 . Of note, between about 98.80 and 98.50 the burned rock midden occurred, and while debitage densities dropped, phosphate values rose.

In Zone 3 of Unit E1022 N1065, phosphate values were highest between elevations of 99.60 and 99.20, which roughly corresponds to relatively high flake counts between elevations of 99.40 and 99.20 . However, a dramatic rise in the flake count between 98.90 and 98.80 was met by the lowest phosphate value from that column sample.

Potassium varied inversely to phosphate within the site, increasing whenever phosphates decreased. So this co-variance of potassium and phosphate would suggest it also is a relatively effective indicator of cultural activity. However, below certain levels, generally as soil zone 4 is entered, potassium rises very sharply. As 
there was very little lithic material to indicate significant cultural activity within the lower levels of the site, it seems likely this sharp rise in potassium is related to soil formation and is not due to cultural activity.

TABLE 3. SOIL ANALYSIS DATA FROM 41 BX 1

\begin{tabular}{|c|c|c|c|c|}
\hline Provenience & Elevation & $\mathrm{pH}$ & $\begin{array}{l}\text { Phosphate } \\
\text { (ppm) }\end{array}$ & $\begin{array}{l}\text { Potassium } \\
\text { (ppm) }\end{array}$ \\
\hline E1012 N1002 & $99.30-99.20$ & 8.2 & 0.1 & 67.0 \\
\hline E1012 N1002 & $99.20-99.10$ & 8.1 & 1.4 & 71.0 \\
\hline E1012 N1002 & $99.10-99.00$ & 8.1 & 0.9 & 88.0 \\
\hline E1012 N1002 & $99.00-98.90$ & 8.0 & 1.4 & 74.0 \\
\hline E1012 N1002 & $98.90-98.80$ & 8.5 & 1.3 & 78.0 \\
\hline E1012 N1002 & $98.80-98.70$ & $8.3 / 8.4$ & $1.4 / 0.9$ & $76.0 / 76.0$ \\
\hline E1012 N1002 & $98.70-98.60$ & 8.4 & 1.3 & 105.0 \\
\hline E1012 N1002 & $98.60-98.50$ & 8.2 & 1.7 & 80.0 \\
\hline E1012 N1002 & $98.50-98.40$ & 8.3 & 2.7 & 79.0 \\
\hline E1012 N1002 & $98.40-98.30$ & 8.4 & 2.1 & 78.0 \\
\hline E1012 N1002 & $98.30-98.20$ & 8.3 & 1.1 & 104.0 \\
\hline E1012 N1002 & $98.20-98.10$ & 8.5 & 2.1 & 83.0 \\
\hline E1012 N1002 & $98.10-98.00$ & 8.3 & 1.4 & 98.0 \\
\hline E1012 N1002 & $98.00-97.90$ & 8.4 & 2.3 & 87.0 \\
\hline $\mathrm{E} 1012 \mathrm{~N} 1002$ & $97.90-97.80$ & 8.4 & 2.6 & 88.0 \\
\hline E1012 N1002 & $97.80-97.70$ & 8.4 & 2.6 & 100.0 \\
\hline E1012 N1002 & $97.70-97.60$ & 8.5 & 1.3 & 112.0 \\
\hline E1022 N1065 & $99.80-99.70$ & 8.0 & 0.7 & 82.0 \\
\hline E1022 N1065 & $99.70-99.60$ & 8.1 & 0.7 & 69.0 \\
\hline E1022 N1065 & $99.60-99.50$ & 8.1 & 1.0 & 63.0 \\
\hline E1022 N1065 & $99.50-99.40$ & 8.1 & 1.1 & 60.0 \\
\hline E1022 N1065 & $99.40-99.30$ & 8.1 & 1.0 & 70.0 \\
\hline E1022 N1065 & $99.30-99.20$ & 8.4 & 1.0 & 60.0 \\
\hline E1022 N1065 & $99.20-99.10$ & 8.2 & 0.7 & 63.0 \\
\hline E1022 N1065 & $99.10-99.00$ & 8.0 & 0.7 & 52.0 \\
\hline E1022 N1065 & $99.00-98.90$ & 8.1 & 0.6 & 69.0 \\
\hline E1022 N1065 & $98.90-98.80$ & 8.4 & 0.3 & 55.0 \\
\hline E1022 N1065 & $98.80-98.70$ & 8.2 & 0.7 & 62.0 \\
\hline E1029 N1001 & $99.30-99.20$ & 8.2 & 2.3 & 64.0 \\
\hline E1029 N1001 & $99.20-99.10$ & 8.2 & 1.4 & 63.0 \\
\hline E1029 N1001 & $99.10-99.00$ & 8.4 & 1.1 & 54.0 \\
\hline E1029 N1001 & $99.00-98.90$ & 8.1 & 1.6 & 52.0 \\
\hline E1029 N1001 & $98.90-98.80$ & 8.2 & 0.9 & 64.0 \\
\hline E1029 N1001 & $98.80-98.70$ & 8.3 & 1.0 & 63.0 \\
\hline E1029 N1001 & $98.70-98.60$ & 8.3 & 1.4 & 51.0 \\
\hline E1029 N1001 & $98.60-98.50$ & 8.3 & 1.4 & 56.0 \\
\hline E1029 N1001 & $98.50-98.40$ & 8.3 & 0.9 & 77.0 \\
\hline E1029 N1001 & $98.40-98.30$ & 8.1 & 0.4 & 92.0 \\
\hline E1029 N1001 & $98.30-98.20$ & 8.3 & 0.9 & 74.0 \\
\hline E1029 N1001 & $98.20-98.10$ & 8.5 & 1.4 & 81.0 \\
\hline E1029 N1001 & $98.10-98.00$ & 8.4 & 1.3 & 93.0 \\
\hline E1029 N1001 & $98.00-97.90$ & 8.3 & 1.1 & 105.0 \\
\hline E1029 N1001 & $97.90-97.80$ & 8.2 & 0.9 & 114.0 \\
\hline
\end{tabular}


TABLE 3. (continued)

\begin{tabular}{|c|c|c|c|c|}
\hline Provenience & Elevation & $\mathrm{pH}$ & $\begin{array}{l}\text { Phosphate } \\
\text { (ppm) }\end{array}$ & $\begin{array}{l}\text { Potassium } \\
\text { (ppm) }\end{array}$ \\
\hline E1029 N1001 & $97.80-97.70$ & 8.3 & 0.7 & 122.0 \\
\hline E1029 N1001 & $97.70-97.60$ & 8.5 & 0.6 & 140.0 \\
\hline E1029 N1001 & $97.60-97.50$ & 8.5 & 1.0 & 195.0 \\
\hline E1029 N1001 & $97.50-97.40$ & $8.5 / 8.5$ & $0.4 / 0.6$ & $208.0 / 213.0$ \\
\hline E1029 N1001 & $97.40-97.30$ & 8.5 & 0.3 & 210.0 \\
\hline E1029 N1001 & $97.30-97.20$ & 8.3 & 0.9 & 230.0 \\
\hline Feature 1 & & 8.0 & 1.6 & 79.0 \\
\hline Feature 2 & & 8.1 & 2.4 & 72.0 \\
\hline Feature 3 & & 8.0 & 2.6 & 77.0 \\
\hline Feature 4 & & 8.1 & 3.7 & 67.0 \\
\hline Feature 5 & & 8.5 & 1.1 & 91.0 \\
\hline Feature 6 & & 8.2 & 4.7 & 76.0 \\
\hline Feature 7 & & 8.2 & 2.1 & 82.0 \\
\hline Feature 8 & & $8.2 / 8.3$ & $2.0 / 1.7$ & $89.0 / 116.0$ \\
\hline Feature 10 & & 8.2 & 1.3 & 92.0 \\
\hline Feature 11 & & $8.2 / 8.0$ & $2.1 / 1.3$ & $63.0 / 88.0$ \\
\hline Burial 2 & & 8.5 & 3.9 & 93.0 \\
\hline Burial 3 & & 8.2 & 2.0 & 98.0 \\
\hline Burial 4 & & 8.5 & 3.0 & 84.0 \\
\hline Burial 5 & & 8.3 & 2.4 & 112.0 \\
\hline Burial 7 & & 8.2 & 2.4 & 78.0 \\
\hline Burial 8 & & 8.3 & 1.7 & 103.0 \\
\hline Burial 10 & & 8.2 & 3.9 & 82.0 \\
\hline
\end{tabular}

TABLE 4. SUMMARY OF SOIL ANALYSIS DATA

\begin{tabular}{|c|c|c|c|c|c|c|}
\hline & $\begin{array}{l}\text { E1012 } \\
\text { N1002 }\end{array}$ & $\begin{array}{l}\text { E1029 } \\
\text { N1001 }\end{array}$ & $\begin{array}{l}\text { E1022 } \\
\text { N1065 }\end{array}$ & Features & Burials & Total \\
\hline $\mathrm{pH}$ mean & 8.3 & 8.3 & 8.2 & 8.2 & 8.3 & 8.3 \\
\hline $\mathrm{pH}$ range & $8.0-8.5$ & $8.1-8.6$ & $8.0-8.4$ & $8.0-8.5$ & $8.2-8.5$ & $8.0-8.5$ \\
\hline Phosphate mean & 1.6 & 1.0 & 0.7 & 2.2 & 2.8 & 1.5 \\
\hline Phosphate range & $0.1-2.7$ & $1.3-2.3$ & $0.3-1.1$ & $1.1-4.7$ & $1.7-3.9$ & $0.1-4.7$ \\
\hline Potassium mean & 85.5 & 101.9 & 64.1 & 82.7 & 92.9 & 90.1 \\
\hline Potassium range & $67.0-112.0$ & $51.0-230.0$ & $58.0-82.0$ & $63.0-116.0$ & $82.0-112.0$ & $51.0-230.0$ \\
\hline Sample Total & 18.0 & 22.0 & 11.0 & 12.0 & 7.0 & 70.0 \\
\hline
\end{tabular}




\section{REFERENCES CITED}

Cornwall, I. W.

1958 Soils for the Archaeologist. Macmillan Co., New York.

Goffer, Z.

1980 Archaeological Chemistry: A Sourcebook in the Applications of Chemistry to Archaeology. Chemical Analysis 55.

Gordon, C. C. and J. E. Buikstra

1981 Soil pH, Bone Preservation, and Sampling Bias at Mortuary Sites. American Antiquity 46(3):566-571.

Gunn, J. and R. Mahula

1977 Hop Hill: Culture and Climatic Change in Central Texas. Center for Archaeological Research, The University of Texas at San Antonio, Special Report 5. 


\title{
APPENDIX II
}

\section{SKELETAL AND DENTAL MATERIALS}

\author{
Richard F. Shoup
}

\section{MATERIALS AND METHODS}

The skeletal sample from $41 \mathrm{BX} 1$ is in a fair state of preservation, though much of the cranial and postcranial elements are fragmentary as they were seldom recovered intact. This is partly the result of seasonal inundation and use of heavy machinery in the area. However, the dentition is well preserved and is often complete.

The present skeletal sample totals 11 individuals. Since the northern boundary of the cemetery was never established, it is not possible to speculate on what proportion of the total cemetery was represented by the 11 individuals. The burial density of the site is reminiscent of the Loma Sandia (41 LK 28) mortuary complex (Shoup 1979). The incomplete excavation of 41 BX 1 does not allow the author to predict either the total number of individuals represented in the cemetery or to make definitive statements about the size of the living population represented by the burial ground.

The adult age at death estimates follow standardized morphological criteria as outlined by Krogman (1962), Acsadi and Nemeskeri (1970), Stewart (1970), Bass (1971), Ubelaker (1978), and Brothwell (1972). With degree of dental attrition, in general, all criteria for age estimates were used to insure an accurate determination. Because of consistently fragmented pelvic elements, age assessments based on the maturational sequences of the symphysis pubis (McKern and Stewart 1957; Gilbert and McKern 1973) were not used.

Cranial suture closure (endocranial and ectocranial) was used as the primary means of age estimation in Burial 11 due to the lack of other criteria. The use of cranial suture closure for estimating adult age has been well reviewed by Singer (1953), McKern and Stewart (1957), and Stewart (1970), and the procedure has severe limitations.

The estimation of age for subadults (under 16 years of age) is based on dental development (Olivier 1960) as outlined by Acsadi and Nemeskeri (1970), by Ubelaker's (1978) dental formation and eruption sequence data, and by long bone lengths (Johnston 1962; Stewart 1968).

Morphological characteristics of the pelvis, skull, and long bones were the determinants of sex identification for the majority of adults, though the angle of the greater sciatic notch of the innominate was the only element used from the pelvis, since the subpubic area was either too fragmentary or missing in all cases. Sexualization was also assessed by skull architecture (supraorbital ridges, mastoid processes, occipital bone, etc.; Acsadi and Nemeskeri 1970). In questionable cases or in corroboration with other elements, the mandible was examined for the shape of the chin (mentum) and the angle at the inferior border of the ascending ramus. The long bones were evaluated for relative degree of robusticity or gracility. Subadults (under 16 years of age) were not examined in this way due to the lack of sexually dimorphic characteristics present only in later years.

All measurements were taken with a standard osteometric board, a large sliding caliper, a large spreading caliper, and a steel tape, following standard methods described by Hooten (1930), Hrdlicka (1947), Martin and Saller (1957), and Bass (1971).

Because of the fragmentary and often incompletely reconstructed cranial and postcranial elements, no discontinuous or discrete traits were evaluated. Berry and Berry (1967), Ossenberg (1976), and Finnegan 
(1978) should be consulted for an explanation of the use of discrete traits in analyzing human skeletal material.

\section{STATURE RECONSTRUCTION}

Several formulas have been developed for the estimation of stature based on the lengths of long bones (Dupertuis and Hadden 1951; Trotter and Gleser 1952, 1958; Genoves 1967). Choice of the proper formula requires consideration of the similarity between the population represented by the archaeological sample and the population represented by the formula (Ubelaker 1978), since regression (prediction) equations are population specific.

Some disagreement exists concerning the application of the proper formula to prehistoric American Indian populations. Bennett (1973) found that Genoves' (1967) formulas provided the best estimates of stature for the Point of Pines sample, while Doran (1974) noted that one of Genoves' formulas produced spurious estimates. Doran (1974) concluded overall, that Trotter and Gleser's $(1952,1958)$ formulas proved the most valid for use in prehistoric American Indian populations, while Ubelaker (1978) feels that Genoves' formulas are most appropriate for Mesoamerican remains, and Trotter and Gleser's formulas may be more reliable for North American Indian skeletal samples from the northern United States.

When possible, both Trotter and Gleser $(1952,1958)$ and Genoves' (1967) formulas are utilized for the present sample. The stature estimates obtained from the skeletons from $41 \mathrm{BX} 1$ are calculated and compared with Group 2 at the Ernest Witte site (Hall 1981) and with Doran's (1974) sample of Texas Indians and are presented in Table 5. The values obtained for the males are equivalent between all three groups when Genoves' (1967) formulas or tables of expected maximum statures are used. Neither student's t-Test nor other tests of significance were computed for any of the mean stature estimates due to the lack of statistical information available for the comparative samples. The male values for $41 \mathrm{BX} 1$ derived from the Trotter and Gleser (1958) equations yielded higher values than those from either the Ernest Witte site (Hall 1981) or from Doran (1974), however.

With the exception of one female height estimate, the remaining female value for stature is well within the range of expected values for the comparative samples.

\section{METRIC ANALYSIS}

In all but one case (Burial 5), only maximum cranial length and maximum breadth measurements were taken. Each measurement is described briefly as follows and is included for individual burials where appropriate.

Maximum cranial length - the maximum glabella-occipital diameter of the cranial vault.

Maximum cranial breadth - maximum biparietal diameter measured from euryon to euryon.

Basion-bregma height-measured as the linear distance between the lowest point on the anterior edge of the foramen magnum to the bregma.

In addition to these measurements, three derived indices are computed, the cranial index (CI), cranial module (CM), and the cranial-height index (Bass 1971), all of which have been calculated for individual burials when cranial elements were available. The three cranial measurements were taken on the skull of Burial 5 only, since the foramen magnum was present for this individual.

Maximum bone lengths were measured on all long bones of the postcranial skeleton when complete. Definitions for the various bone-specific measurements are available from Hooten (1930), Hrdlicka (1947), and Bass (1971). 
TABLE 5. ESTIMATED STATURE OF THE SKELETAL SAMPLE FROM 41 BX 1

\begin{tabular}{|c|c|c|c|c|c|}
\hline \multirow[t]{2}{*}{ Site } & & \multicolumn{2}{|c|}{ Genoves (1967) } & \multicolumn{2}{|c|}{ Trotter and Gleser (1958) } \\
\hline & & $\underline{\text { Male }}$ & $\underline{\text { Female }}$ & $\underline{\text { Male }}$ & $\underline{\text { Female }}$ \\
\hline \multirow[t]{6}{*}{$41 \mathrm{BX} 1$} & & 162.5 & 151.5 & 166.3 & 151.5 \\
\hline & & 166.5 & 166.5 & 175.9 & 170.3 \\
\hline & & 169.3 & - & 176.4 & - \\
\hline & Mean & 166.1 & 159.1 & 172.9 & 160.9 \\
\hline & Range & $162.5-169.3$ & $151.5-166.5$ & & \\
\hline & Undetermined & 169.5 & & 172.1 & \\
\hline Ernest Witte & & 169.5 & 159.5 & & \\
\hline \multirow[t]{7}{*}{ Group 2} & & 170.3 & 147.5 & & \\
\hline & & 163.3 & 152.0 & & \\
\hline & & 165.3 & 149.5 & & \\
\hline & & 175.3 & - & & \\
\hline & & 172.5 & - & & \\
\hline & Mean & 169.4 & 152.1 & & \\
\hline & Range & $163.3-175.3$ & $147.5-159.5$ & & \\
\hline \multicolumn{6}{|l|}{ Texas Indians } \\
\hline & Mean & 165.45 & 157.7 & & \\
\hline & Range & $163.5-175.3$ & $147.5-159.5$ & & \\
\hline
\end{tabular}

Note: All measurements are expressed in centimeters

Source: Estimated Maximum Statures (Genoves 1967), formulas (Trotter and Gleser 1958), Texas Indians (Doran 1974)

\section{INDIVIDUAL BURIAL ANALYSIS}

\section{BURIAL 1}

Burial 1 probably represents the remains of a two to three year old child. Although some questions exist as to the orientation of the body, the child was probably lying on the right side with a possible orientation to the east-northeast.

Although the skeleton was badly crushed, some reconstruction of the cranium was possible, including portions of the right frontal, parietal and temporal bones. Although known to exhibit considerable variability, the coronal and sagittal sutures were examined and open. In addition to the cranial remains, a portion of the left ascending ramus and a segment of the body of the mandible was recovered. Other postcranial elements include two vertebral fragments, four rib fragments, and a 50 -mm section of the diaphysis of a humerus with a midshaft diameter of $12.6 \mathrm{~mm}$. 
Age was determined by the presence of a lower premolar germ and a lower $\mathrm{M}_{1}$ germ, both with incomplete crown formation. Since the premolar crown is, on the average, fully developed by five to seven years of age and $\mathrm{a} \mathrm{M}_{1}$ by two and one-half to three years, the two to three year age estimate is appropriate.

No pathology was noted, and the cause of death is unknown.

\section{BURIAL 2}

Burial 2 represents an adult male, 17-25 years of age. The form of disposal was probably a single, primary inhumation. The state of preservation is relatively good, but the skull, scapula, and pelvis are crushed. The remainder of the skeleton is virtually complete.

The body was lying on the right side with the skull facing northwest, and general orientation was east-northeast. The left and right legs were flexed at the knees at $45^{\circ}$ and $60^{\circ}$, respectively, while the arms appeared to be extended toward the knees.

Sex was determined on the angle of the greater sciatic notch of the left innominate $\left(30^{\circ}\right)$ and on the morphology of the skull and mandible (Acsadi and Nemeskeri 1970). The specific characters include a lowly vaulted cranium, a prominent occipital bone with well-defined nuchal lines, a large mastoid process, and heavy supraorbitals. Reconstruction of the skull was sufficient to obtain maximum length $(18.5 \mathrm{~cm})$ and breadth $(14.1 \mathrm{~cm})$ from which the cranial index could be calculated, yielding a value of 76.22 , which places this individual in the mesocephalic or medium range (Bass 1971).

Age was estimated on the degree of dental attrition. While one third molar (lower left) recovered with the burial exhibits slight enamel polishing on the occlusal surface, the remainder of the teeth show wear rates consistent with an individual 17-25 or in the young adult age range (Brothwell 1972).

Stature was calculated from Genoves' (1967) table of expected maximum stature for the right fibula $(162.5 \mathrm{~cm})$ and was computed from Trotter and Gleser's (1958) formula for Mongoloid males using the right fibula:

$$
2.40(35.7)+80.56=166.26 \mathrm{~cm} \pm 3.24 \mathrm{~cm}
$$

Both values fall within the expected range of values.

Besides one carious lesion on the lingual aspect of the lower left $\mathrm{M}_{3}$, no pathology was noted. Cause of death is unknown.

BURIAL 3

A young adult individual, classified as a primary, single interment, Burial 3, could also possibly be part of a multiple burial containing Burials 2 and 4 . The skeleton is essentially complete except for a few missing carpals, metacarpals, tarsals, and phalanges of the feet and hands. In addition, four extraneous permanent teeth were recovered with this individual.

The body was tightly flexed with the upper right arm bent at the elbow $60^{\circ}$ and the left humerus displaced. Both legs are tightly flexed at the knees (left $25^{\circ}$, right $30^{\circ}$ ). The body was placed on the left side with the skull facing east and the body oriented in an east-northeasterly direction.

Sex identification was made on the angle of the greater sciatic notch of the innominate, about $50^{\circ}$, and on the morphology of the skull. The morphological features of the skull include the lack of heavy supraorbitals, a relatively obtuse mandibular angle, and a mentum (chin) of the mandible lacking the well-defined "square" shape. The skull, on the other hand, is relatively lowly vaulted, a primarily male characteristic. The long 
bones, although lacking a well-defined robust appearance, are relatively long as indicated by the reconstruction of stature formulas computed. All of the morphological features mentioned can be considered either "indifferent" or "feminine" according to Acsadi and Nemeskeri's (1970) method for determining sex and sexualization. I must therefore conclude, that a definitive sex estimate of this individual is not possible at this time.

Age was estimated on dental attrition only (Brothwell 1972) with three of the four third molars erupted and present. All showed light wear on their occlusal surfaces. The lower left $M_{3}$ may have a carie on the occlusal surface of the crown.

In addition to the 30 permanent teeth associated with Burial 3, four extraneous permanent teeth were recovered. These are a left upper $\mathrm{P}^{1}, \mathrm{P}^{2}, \mathrm{M}^{1}$, and $\mathrm{M}^{2}$. All exhibit attrition rates greater than those of Burial 3 and correspond to an individual 45 years or older (Brothwell 1972). The wear on these teeth is also greater than any of the other burials directly associated with Burial 3.

No cranial measurements were possible because of the fragmentary nature of the skull.

Stature was calculated utilizing Trotter and Gleser's (1958) formulas for a Mongoloid male and Genoves' (1967) table of expected maximum stature for the left radius and right fibula. Trotter and Gleser's (1958) formulas produced values of $151.77 \mathrm{~cm} \pm 4.45 \mathrm{~cm}$ for the fibula and $169.71 \mathrm{~cm} \pm 4.60 \mathrm{~cm}$ for the radius. The stature obtained from the fibula is closer to values derived for contemporaneous females of central Texas (Doran 1974; Hall 1981). Genoves' (1967) stature estimates taken from the table of expected maximum stature yield similarly equivocal results when computed for both sexes: males - fibula, 179.5 and radius, $164.0 \mathrm{~cm}$; females - fibula, $169.5 \mathrm{~cm}$ and radius, $164.0 \mathrm{~cm}$. The variable and somewhat puzzling stature estimates further add to the uncertainty of making a definitive sex determination.

No pathology was noted except the dental carie, and the cause of death is unknown.

\section{BURIAL 4}

Burial 4 is probably that of a young female 16 to 18 years of age. Although denoted as a single, primary inhumation, this individual could be part of a multiple burial, including Burials 2 and 3 which were in close approximation.

The skeleton is complete except that many of the ribs, patellae, vertebrae, and some phalanges of the feet are missing. The body was on its left side and appeared slumped to the left. The right arm was extended with the position of the left arm uncertain. Both of the legs are tightly flexed at the knee at about $65^{\circ}$.

Sex determination was made from the angle of the greater sciatic notch of the right innominate $\left(70^{\circ}\right)$, morphology of the skull and mandible, and the overall gracility of the long bones. The mastoid processes of the temporal bone and the superior line of the occipital bone are not prominent or particularly well defined. The mentum (chin) of the mandible is slightly rounded and is characterized as "indifferent" in Acsadi and Nemeskeri's (1970) grading of sexual characteristics.

Age was estimated primarily on the degree of epiphyseal closure of specific long bones (Ubelaker 1978) and secondarily by the degree of dental attrition.

The proximal epiphysis of the right fibula has an ununited diaphyseal surface which appears rough and irregular. Although the epiphysis is missing, it is possible that some fusion could have occurred. Ubelaker (1978) gives the approximate age of epiphyseal closure for this bone at 14 to 18 years of age in females. The right ulna, radius, and tibia also show a similar lack of epiphyseal closure. Ubelaker's (1978) age estimates for the ulna, radius, and tibia are 16-19 years old, 13-16 years old, and 14-16 years old, respectively. 
The dentition is complete except for the upper left canine and $\mathrm{I}^{2}$ and the upper right $\mathrm{I}^{1}$. The lower third molars have not erupted, and no radiographs of the mandible were taken. The upper left $\mathrm{M}^{3}$ is present, although it is below the gingival level or gum line. Attrition is light to moderate on the molars and light on the remainder of the teeth. Wear rates correspond to a chronological age estimate of 17-25 years of age for the first and second molars (Brothwell 1972).

No cranial measurements were made due to the fragmentary nature of the skull. Since only the left and right radii were complete, they were used for the reconstruction of stature. Genoves' (1967) table for the estimation of maximum stature was used and yielded a value of $151.5 \mathrm{~cm}$ using the right radius $(21.6 \mathrm{~cm})$. No pathology was noted, and the cause of death is unknown.

\section{BURIAL 5}

An adult male of 25-35 years of age was a primary inhumation, Burial 5. Portions of another adult male skeleton (Burial 5A) were overlying Burial 5.

The fully articulated skeleton is complete except for a few missing phalanges from the feet and hands. The body was lying on the back with the head lying on the right side and facing northwest. The right arm is tightly flexed at the elbow $\left(15^{\circ}\right)$ with the hand placed near the face. The left arm is semiflexed at the elbow at about $80^{\circ}$.

Both legs are tightly flexed at the knees and drawn upwards towards the area of the chest with the legs crossed near the ankles. Both femora are flexed at about $20^{\circ}$ to the long axis of the body with the tibiae tightly flexed at $30^{\circ}$ to the femur. The general orientation of the body was east to west.

Sex was determined on the basis of the angle of the greater sciatic notch $\left(30^{\circ}\right)$, skull, and mandibular morphology. Overall, the skull suggests a robust individual. The cranium is lowly vaulted, the supraorbitals are well pronounced, the mastoid processes of the temporal bones are well defined and heavy, and the external occipital protuberance is quite distinct with the superior nuchal line prominent.

Since the skull is almost complete, several cranial measurements are given: the maximum length (glabella to occipit) is $18.6 \mathrm{~cm}$, and the maximum breadth (biparietal) is $13.8 \mathrm{~cm}$. From these two measurements the cranial index was computed as 74.19. This is considered by Bass (1971:63) to fall within the dolichocephalic or long-headed category. The cranial module (Bass 1971:64) was calculated from a maximum height (basion-bregma) of $12.7 \mathrm{~cm}$, providing a numerical estimate of the size of the skull:

$$
\text { Cranial Module }=\frac{\text { Length (186) }+ \text { breadth (138) }+ \text { height }(127)}{3}=153.0
$$

The cranial length-height index as an expression of the ratio of height to length in the skull (Bass 1971:64) and calculated as a percentage is as follows:

$$
\text { Length-Height Index }=\frac{\text { Basion-bregma height }(127) \times 100}{\text { Maximum length (186) }}=68.28 \%
$$

Martin's range as cited by Bass (1971) for the cranial-height index places the skull for Burial 5 in the chamaecrany or low skull category. 
And finally, the cranial breadth-height index, an expression of the ratio of height to breadth and expressed as a percentage, was computed:

$$
\text { Breadth-Height Index }=\frac{\text { Basion-bregma height }(127) \times 100}{\text { Maximum breadth (138) }}=92.03 \%
$$

Broca's scale as interpreted by Bass (1971) places this skull within the mesocephalic or average range for this index.

On the mandible, the chin is very square with a mandibular angle of about $95^{\circ}$.

Age was estimated from attrition (Brothwell 1972). All of the permanent teeth are present, with the upper and left first premolars rotated slightly in their sockets. An initial examination of the maxillary central incisors revealed an apparently incisive foramen suggesting the possibility of a cyst in that region. A radiograph by Dr. Richard Nichols clearly revealed the distal curving of the roots of the central incisors possibly in response to a crypt which probably contained a supernumerary tooth (see Fig. 35,a).

Stature was computed from the right fibula using both Trotter and Gleser's (1958) formula for Mongoloid males and Genoves' (1967) table of expected maximum stature which produced values of $171.1 \mathrm{~cm} \pm 3.24 \mathrm{~cm}$ and $167.0 \mathrm{~cm}$, respectively. A value of $0.06 \mathrm{~cm}$ was subtracted from the estimate derived from Trotter and Gleser's (1958) formula as a compensation for the effects of aging.

No pathology was found in this individual, and the cause of death is unknown.

\section{BURIAL 5A}

Burial 5A probably represents the secondary interment of a disturbed primary inhumation of a male, 17-25 years of age. The remains were found in close approximation to Burial 5; the skull of Burial 5A was lying near the left side of Burial 5. In addition to the skull, the mandible, right scapula, both radii, the right ulna, portions of the pelvis, the left femur, both tibiae, a left fibial fragment, the navicular (carpal), and one tarsal are present.

The skull was found lying on the right side with the mandible located on top of the left scapula of Burial 5 . The right scapula and one radius of Burial 5A were lying in the chest area of Burial 5.

Sex was determined on the basis of skull and mandible morphology with the skull appearing quite robust and lowly vaulted. The external occipital protuberance is pronounced, and the mastoid process of the temporal bone is large. The mandible is robust in appearance and almost complete.

Age was estimated on dental attrition (Brothwell 1972). The entire maxilla and all upper dentition are missing, and all of the anterior dentition of the mandible, including the first premolar on the right side, is missing. No pathology was associated with the tooth loss which probably occurred in situ. Attrition rates are consistent with a 17-25 years of age range (Brothwell 1972).

Reconstruction of the skull was sufficient to provide length and width measurements. The maximum length is $20.3 \mathrm{~cm}$ and the maximum breadth, $13.5 \mathrm{~cm}$. The cranial index of 65.52 confirms the dolichocephalic or considerably long-headedness of this individual. There may have been a measurement error, since the cranial index is considerably lower than any of the other individuals represented at this site and should be viewed with some caution.

Reconstruction of stature was calculated from Trotter and Gleser's (1958) formulas for adult male Mongoloids and was estimated from Genoves' (1967) table of expected maximum stature from the left radius and right ulna. Estimates of $176.52 \pm 4.60 \mathrm{~cm}$ and $176.45 \pm 4.66 \mathrm{~cm}$ were derived from Trotter and Gleser's 


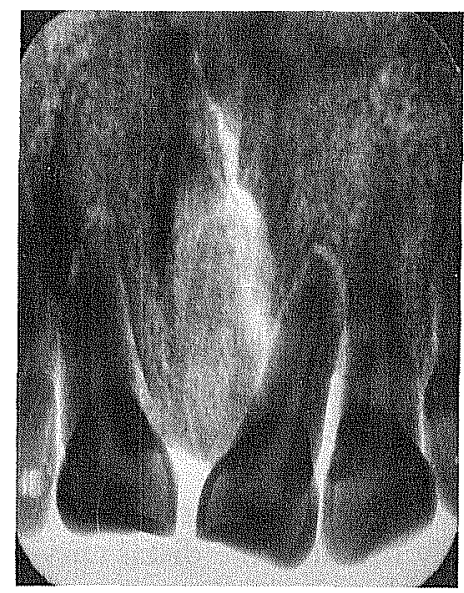

a

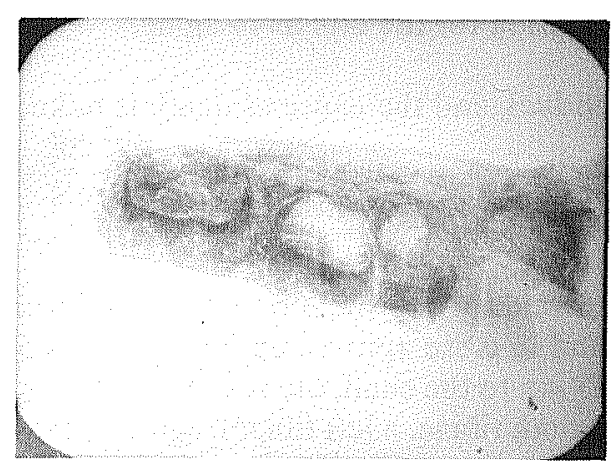

b

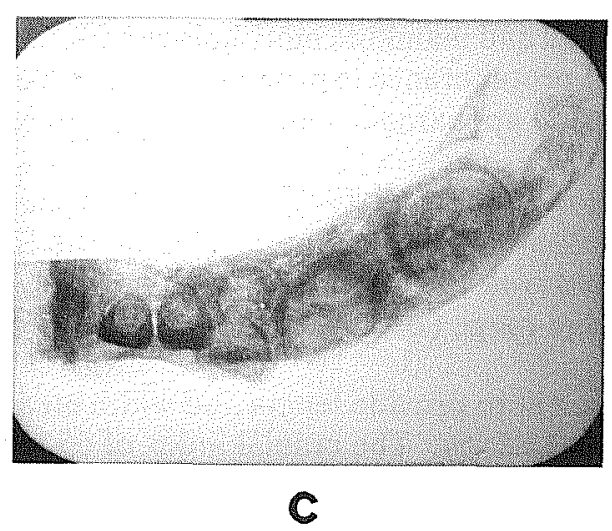

Figure 35. Radiographs for Burials 5 and 8. a, radiograph of upper central incisors, Burial $5 ; \mathbf{b}$, radiograph of right side of mandible, Burial $8 ; \mathrm{c}$, cusp development detail, Burial 8. 
(1958) equations for the radius and ulna, while values of $169.5 \mathrm{~cm}$ and $160.0 \mathrm{~cm}$ were produced from Genoves' (1967) table. In this instance, Genoves' (1967) values seem closer to the means for males from contemporary Texas Indian groups (Doran 1974; Hall 1981).

A periostitic condition was present on the anterior surfaces of the diaphyses of both femora and tibiae. Steinbock (1976) describes osteomyelitis (which includes periostitis) in general terms as an "infection of the bone by various kinds of microorganisms," and defines periostitis as inflammations of the bone (Steinbock 1976:60). Periostitis can also be induced or aggravated by poor hygiene or malnutrition, and in the New World periostitis and osteomyelitis are common pathological lesions in early populations and can be found in "Indian populations of every archaeological horizon and geographical location" (Steinbock 1976:64).

In addition to the periostitis, a dart point was found inside of the right parietal following analysis in the laboratory. A possible entry point was located in the right parietal, and a radiograph was made of this location. Although no distinct radiating fracture lines appear on the radiograph, the edges of the opening are beveled ecto to endrocranially. This proves inconclusive since other missing parts of the cranial vault exhibit similar beveling.

It seems unlikely that the dart point would have been placed into the skull for any ceremonial reason, although this skull was a probable secondary interment and could have been exhumed prior to reburial. It is also possible that this individual could have sustained a mortal wound to the head from a dart entering the skull from an unknown point.

\section{BURIAL 6}

Burial 6 contained extremely fragmentary remains, possibly of a human infant. Three ribs appeared to be in proper anatomical position with the remainder of the material consisting of unidentifiable long bone and some possible skull fragments. The orientation of the body is unknown, and only a small piece of red ocher was recovered in close association with the remains.

No age estimate is possible, and no pathology was noted. The cause of death is unknown.

\section{BURIAL 7}

Burial 7 contained the remains of an infant ranging in age from newborn to six months of age. Only the leg bones and a few possible pelvis fragments were recovered. The legs are semiflexed at the knees at approximately $50^{\circ}$.

The body was probably lying on the left side and may have been oriented in a north-northwest direction.

Since this individual is a subadult no sex estimate was possible, but age was estimated on the basis of the lengths of the long bones of the legs (Johnston 1962; Stewart 1968). Stewart's (1968) regression line for age prediction as presented by Bass (1971) was calculated from the right femur $(80.0 \mathrm{~mm})$ and corresponds to a newborn. The left femur is $54.0 \mathrm{~mm}$ long and is assumed to be incomplete. Johnston's (1962) table for age estimation from femur length, based on the Indian Knoll data, is equivalent to a newborn to six month old infant (child).

No pathology was noted, and age of death could not be established.

\section{BURIAL 8}

Burial 8 contained the articulated skeletal remains of an almost complete eight to 10 month old child and was a single inhumation. The child was lying on the left side facing northeast with the body oriented southeast 
to northwest. The legs were tightly flexed $\left(15^{\circ}\right)$, though the right humerus was the only bone recovered from the upper body.

Age was estimated from the dentition present in the mandible. Only the right side of the mandible was recovered, and only the right first and second deciduous incisors were visible above the bone line. A series of radiographs of the mandible was taken by Dr. Nichols to determine the presence and/or absence or degree of calcification of any teeth present.

A lateral radiograph of the right side revealed the presence of the lower right deciduous canine and first and second deciduous molars (see Fig. 35,b). The canine appeared to have a fully developed crown which occurs, on the average, at nine months of age (Olivier 1960) as cited by Acsadi and Nemeskeri (1970). The cusps of the first molar appear fairly distinct, occurring at about six months of age. The cusps (see Fig. 35,c) of the second molar, although still continuous for the most part, have begun to differentiate, which begins on the average at 10-11 months of age (Olivier 1960) as reviewed by Acsadi and Nemeskeri (1970).

The final age estimate based on crown development, calcification of the crowns, and eruption schedules is therefore, eight to 10 months of age.

No pathology was noted, and the cause of death is unknown.

\section{BURIAL 9}

Burial 9 is probably the remains of a newborn. This incomplete skeleton includes fragments of the temporal bone, one side of the mandible, possible scapula fragments, a clavicle fragment, a diaphysis of a humerus, and a calcaneus or talus fragment.

Neither body orientation nor position are known.

Age was estimated from dentition. The mandible is broken, making access to the teeth possible and the use of radiographs unnecessary. The first and second deciduous incisors (side unknown) although not erupted, appear to have almost complete crown development. Complete crown development occurs in the lower first and second incisors at two and one-half to three months, respectively (Olivier 1960), as cited by Acsadi and Nemeskeri (1970). One deciduous molar crown was also recovered though it lacks complete crown development. This occurs from five and one-half to six months of age depending on molar type.

The final age estimate for Burial 9 is from birth to two months, but may be a newborn (birth to one month).

\section{BURIAL 10}

Burial 10 represents the single, primary inhumation of a young female in the late teens or early adulthood, probably 16-19 years of age. Although the skull was badly crushed in situ, the skeleton is complete except for a few missing carpal, metacarpals, and phalanges of the hand.

The body was placed on the left side with the face directed south and the body oriented in an easterly direction. The right arm is partially flexed at the elbow at about $100^{\circ}$, and the left arm is flexed at the elbow at $90^{\circ}$. Both legs are tightly flexed at the knees with the left at $45^{\circ}$ and the right at $35^{\circ}$.

Sex determination was made primarily on the angle of the greater sciatic notch of the innominate $\left(70^{\circ}\right)$ and secondarily by skull morphology. Only partial reconstruction of the skull was possible since most of the left parietal and temporal bones are fragmentary. The supraorbitals although not prominent, are relatively thin and sharply delineated, and the skull seemed gracile with the right mastoid process small. Only maximum cranial length could be measured $(15.9 \mathrm{~cm})$. 
Age was estimated on epiphyseal closure of several of the long bones and was corroborated by dental eruption schedules and attrition rates. The proximal end of the right humerus and right fibula have the rough and irregular shape characteristic of the end of a bone shaft prior to epiphyseal union, 13-19 years of age (Ubelaker 1978).

The lower third molars, although above the bone line in the mandible, had not erupted through the gingivae prior to death, while the upper $\mathrm{M}^{3}$ had erupted and was fully occluded. The low attrition rate corresponds to a young adult (Brothwell 1972) as do the unerupted third molars. The final age estimate of 16-19 years of age seems consistent with the criteria used.

Reconstruction of stature was determined from Genoves' (1967) table of expected maximum stature for the left fibula $(163.0 \mathrm{~cm})$ and was calculated utilizing the right tibia:

$$
\text { Stature }-2.72(39.0)+63.781=169.86 \pm 3.513 \mathrm{~cm}
$$

Both values exceed the range of height values given for Group 2 at the Ernest Witte site (Hall 1981) and by Doran (1974) for his Texas Indian sample.

No pathology was noted for this individual, and the cause of death is unknown.

\section{BURIAL 11}

Burial 11, an extremely fragmentary, highly disturbed, partial skeleton, probably represents a young to midadult age male, 25-40 years old. The skull, badly crushed, lacked the maxilla and mandible. No other postcranial elements were present, but they may have been removed by heavy machinery operating in the area.

Although the skull was found lying on the right side, no other information on deposition, position, or orientation of the body is available.

Sex was determined on the degree of sexualization of secondary sex characteristics of the skull (Acsadi and Nemeskeri 1970). The supraorbitals are fairly heavy and pronounced, the mastoid processes of the temporal bones are relatively large and marked, and the squamous portion of the occipital bone (nuchal lines) are well defined and fairly heavy.

Age was estimated on the degree of cranial suture closure, although considered highly variable in their closure rates, they can provide an approximation of age (Krogman 1962; Stewart 1970). The coronal suture on the left side was missing both the pars bregmatica and pars pterica, but showed a C 33 rate based on Martin's scale (suture open $=0$, incipient closure $=1$, closure in progress $=2$, advanced closure $=3$, and closed suture $=4$ ) as outlined in Acsadi and Nemeskeri (1970). The overall degree of suture closure was determined from the averages of individual sutures viewed both endo and ectocranially. The sagittal suture displayed a rate of $\$ 4433$ while the lambdoid expressed L222 for both sides.

A tentative age estimate could be expressed possibly as a young to midadult from 25-40 years of age.

No pathology was noted on the skull, and the cause of death is unknown.

\section{$\underline{\text { SUMMARY }}$}

The skeletal and dental material from 41 BX 1 was examined to provide information on the distribution of age, sex, stature estimation; to describe the metric variables of the cranial and postcranial skeleton; and to assess the general health status of the sample as compared to other contemporary prehistoric American Indian skeletal samples from Texas (Goldstein 1957; Doran 1974; Hall 1978, 1981). 
Since the limits of the cemetery were never established, no predictions on total number of individuals represented in the cemetery were possible which eliminated the use of paleodemographic analysis. No definitive statements can be made concerning the normality of the age and sex distributions of the individuals from the Olmos cemetery.

While it is difficult to generalize from such a small sample, the people represented by the 11 individuals were relatively short, with the males averaging about five feet five inches tall, while the female was just under five feet tall. Their heights are slightly lower than the males from Group 2 from the Ernest Witte site (Hall 1981) but about equal to those males analyzed by Doran (1974).

Only one of the seven adults represented at the Olmos Dam site exhibited any postcranial pathology (Burial $5 \mathrm{~A})$, periostitis on both tibiae and femora. Group 2 of the Ernest Witte site showed an incidence of postcranial pathology in adults of $43.7 \%$ with only one having osteomyelitis. Goldstein (1957) found that of 92 adults in early Texas Indian groups, $37.1 \%$ had pathologies of the postcranial skeleton with inflammatory bone lesions representing $28.3 \%$ of the total. In summarizing data on early Indian groups from south Texas, Goldstein (1957) found that 11.1 to $59.1 \%$ had nonspecific skeletal abnormalities, while the present sample has a $14.3 \%$ incidence of postcranial pathology.

Dental caries were found only on the third molars of two of the seven adults (29\%) at site $41 \mathrm{BX} 1$ compared with Hall's (1981) reported incidence of $22 \%$ of adults at the Ernest Witte site. In general, like other prehistoric American Indian sites from Texas and the United States, attrition rates are relatively high compared to modern standards, though rates for $41 \mathrm{BX} 1$ are comparable for Indian groups of this period.

\section{ACKNOWLEDGMENTS}

The author wishes to thank Richard Nichols, D.D.S., for the dental radiographs and clinical evaluations of dentition, and Mr. Charles Grimland, X-ray technician, for assistance with cranial radiographs.

\section{REFERENCES CITED}

Acsadi, G. and J. Nemeskeri

1970 History of Human Life Span and Mortality. Akademiai Kiado, Budapest.

Bass, W. M.

1971 Human Osteology: A Laboratory and Field Manual of the Human Skeleton. University of Missouri, Columbia.

Bennett, K. A.

1973 The Indians of the Point of Pines, Arizona. Anthropological Papers of the University of Arizona 23. Tucson.

Berry, A. C. and R. J. Berry

1967 Epigenetic Variation in the Human Cranium. Journal of Anatomy 101(2):361-379.

Brothwell, D. R.

1972 Digging Up Bones, The Excavation, Treatment, and Study of Human Skeletal Remains. 2nd edition. British Museum of Natural History, London. 
Doran, G. H.

1974 The Long Bones of Texas Indians. M.A. thesis, The University of Texas at Austin.

Dupertuis, C. W. and J. A. Hadden, Jr.

1951 On the Reconstruction of Stature from Long Bones. American Joumal of Physical Anthropology 9:15-53.

Finnegan, M.

1978 Non-metric Variation of the Infracranial Skeleton. Journal of Anatomy 125(1):23-37.

Genoves, S.

1967 Proportionality of the Long Bones and their Relation to Stature among Meso-Americans. American Journal of Physical Anthropology 26:67-78.

Gilbert, B. M. and T. W. McKern

1973 A Method of Aging the Female Os Pubis. American Journal of Physical Anthropology 38(1):31-38.

Goldstein, M. J.

1957 Skeletal Pathology of Early Indians in Texas. American Journal of Physical Anthropology 15(3):299-307.

Hall, G. D.

1978 Investigations at the Ernest Witte Site: A Retrospective Summary. Paper presented at the Annual Meeting of the Texas Archeological Society, Corpus Christi, Texas.

1981 Allens Creek: A Study in the Cultural Prehistory of the Lower Brazos River Valley. The University of Texas at Austin, Texas Archeological Survey, Research Report 61.

Hooten, E. A.

1930 The Indians of Pecos Pueblo. Yale University Press, New Haven.

Hrdlicka, A.

1947 Practical Anthropology. Edited by T. D. Stewart. Wistar Institute, Philadelphia.

Johnston, F. E.

1962 Growth of the Long Bones of Infants and Young Children at Indian Knoll. American Journal of Physical Anthropology 20:249-254.

Krogman, W. M.

1962 The Human Skeleton in Forensic Medicine. C. C. Thomas, Springfield, Illinois. 
Martin, R. and K. Saller

1957 Lehrbuch der Anthropologie. Gustav Fischer Verlag, Stuttgart.

McKern, T. W. and T. D. Stewart

1957 Skeletal Age Changes in Young American Males. Quartermaster Research and Development Center Environmental Protection Research Division, Technical Report EP-45. Natick, Massachusetts.

Olivier, G.

1960 Pratique Anthropologique. Vigot FreFrus, editeurs. Paris.

Ossenberg, N.S.

1976 Within and Between Race Differences in Population Studies Based on Discreet Traits of the Human Skull. American Joumal of Physical Anthropology 45:701-716.

Shoup, R. F.

1979 Loma Sandia (41 LK 28) Skeletal Analysis. Unpublished preliminary report on file at the Texas Department of Highways and Public Transportation, Austin.

Singer, R.

1953 Estimation of Age from Cranial Suture Closure. Journal of Forensic Medicine 1(1):52-59.

Steinbock, R. T.

1976 Paleopathological Diagnosis and Interpretation: Bone Diseases in Ancient Human Populations. C. C. Thomas, Springfield, Illinois.

Stewart, T. D.

1968 Identification by the Skeletal Structure. In Gradwohl's Legal Medicine, edited by F. E. Camps. Williams and Wilkins Co., Baltimore.

1970 Personal Identification in Mass Disasters. Smithsonian Institution, Washington, D.C.

Trotter, M. and G. C. Gleser

1952 Estimation of Stature from Long Bones of American Whites and Negroes. American Journal of Physical Anthropology 10:463-514.

1958 A Re-evaluation of Estimation of Stature Based on Measurements of Stature Taken During Life and of Long Bones After Death. American Journal of Physical Anthropology 16:79-123.

Ubelaker, D. H.

1978 Human Skeletal Remains - Excavation, Analysis, Interpretation. Aldine Publishing Company, Chicago.

Wells, C.

1964 Bones, Bodies, and Disease: Evidence of Disease and Abnormality in Early Man. Pragger, New York. 


\section{APPENDIX III}

PROVENIENCE OF ARTIFACTS 


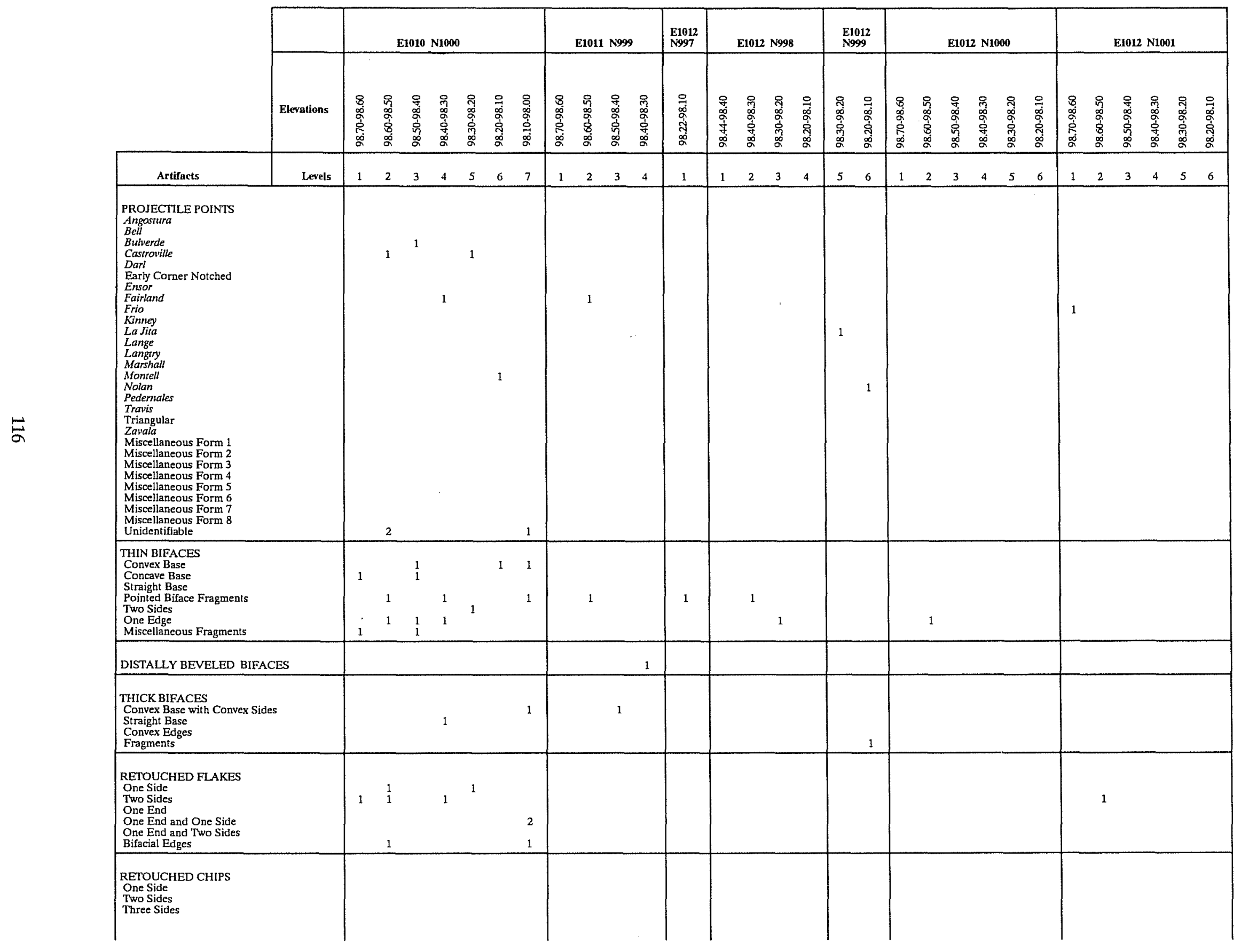




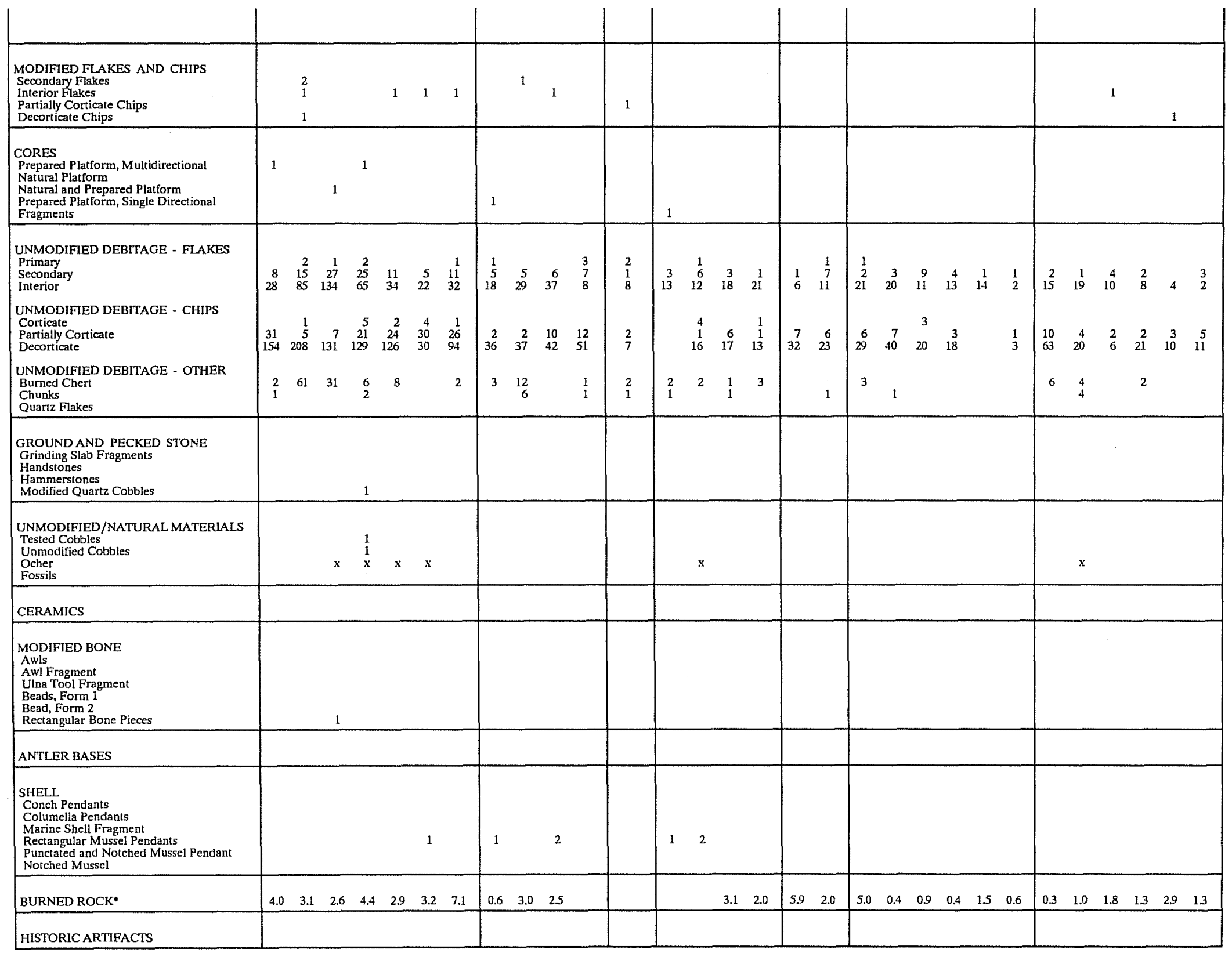




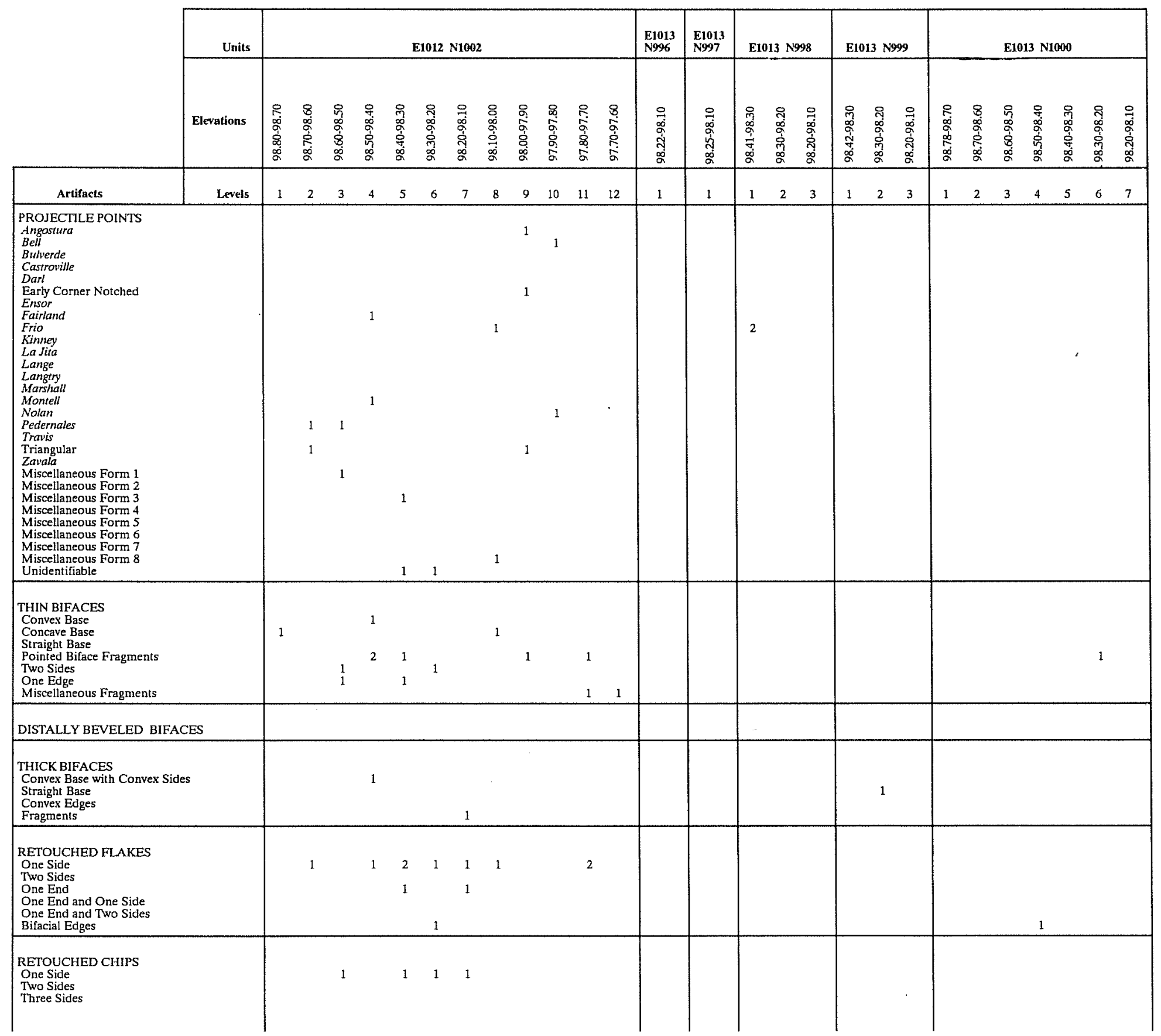




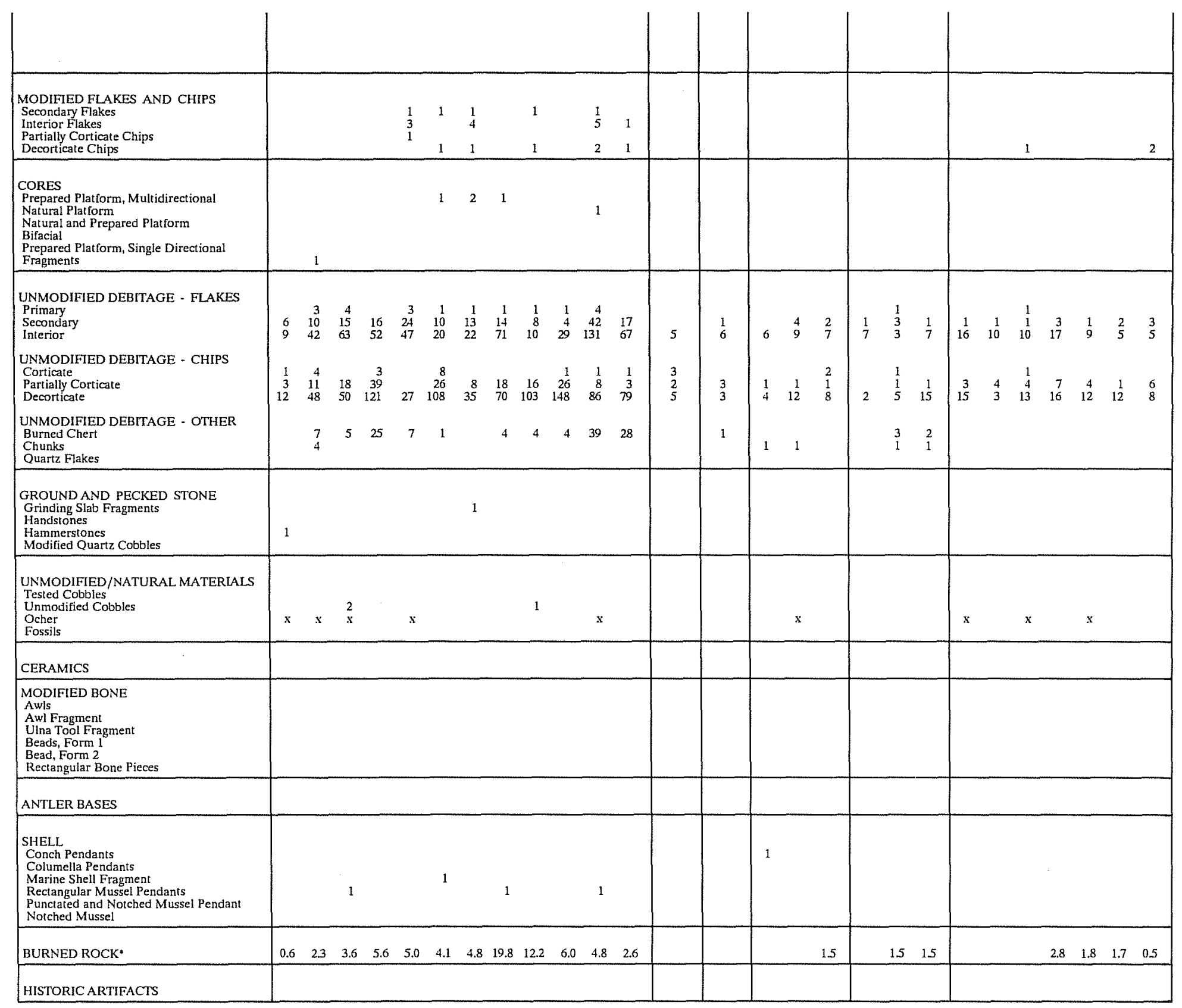




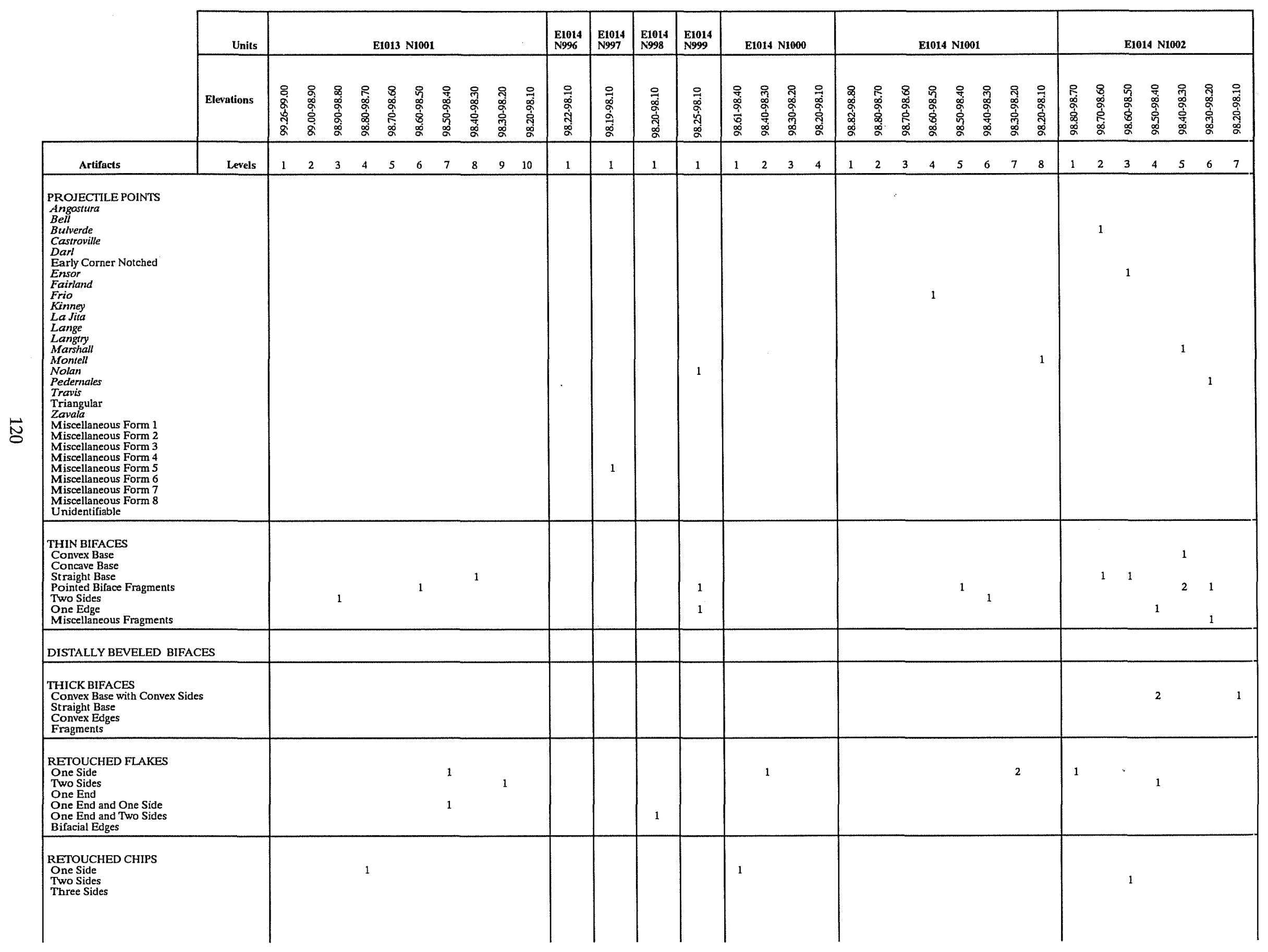




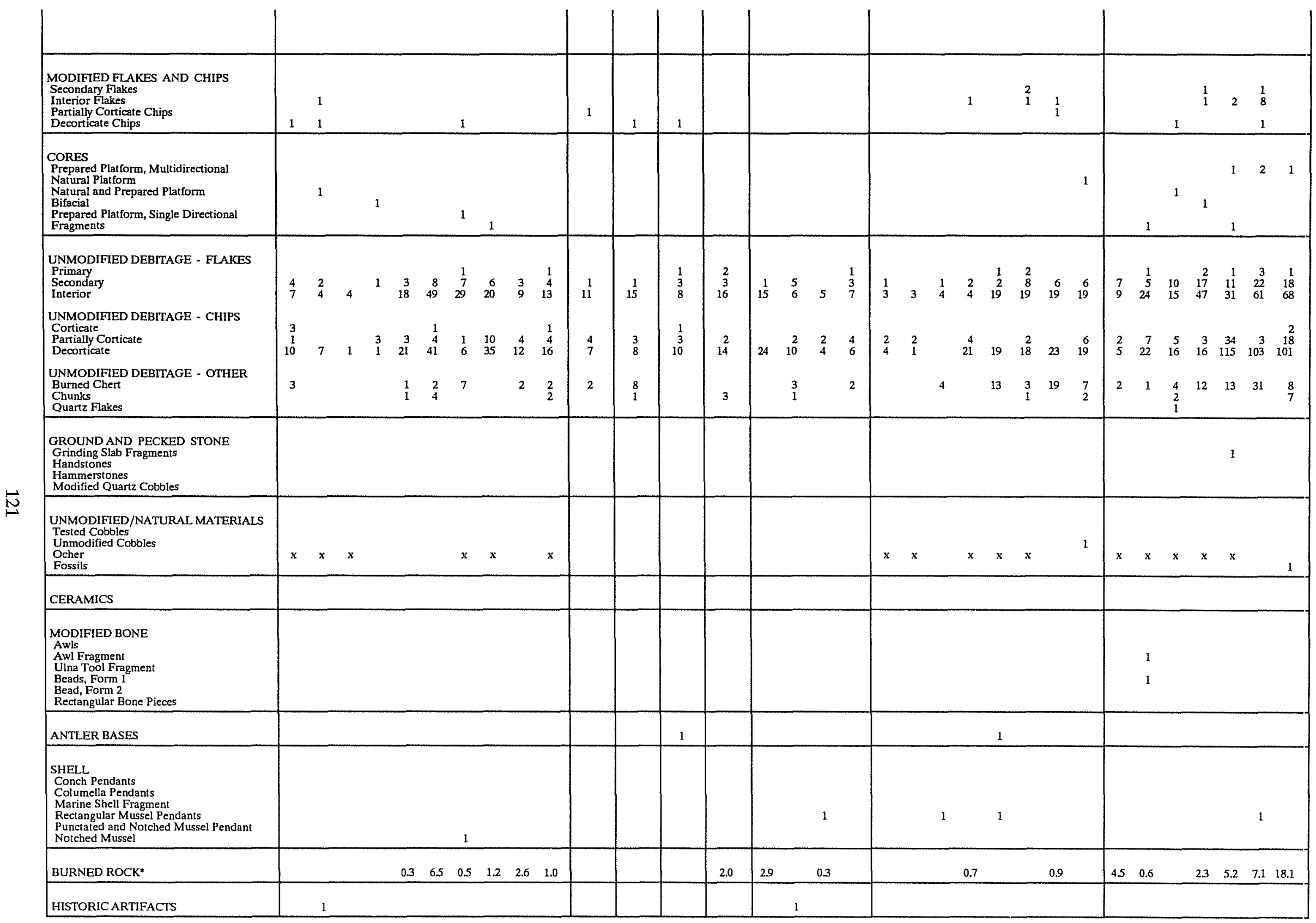

Burned rock weights to nearest tenth of a kilogram
$x=$ presence 


\begin{tabular}{|c|c|c|c|c|c|c|c|c|c|c|c|c|c|c|c|c|c|c|c|c|}
\hline & Units & $\begin{array}{l}\text { E1015 } \\
\text { N9997 } \\
\end{array}$ & $\begin{array}{l}\text { E1015 } \\
\text { N999 } \\
\end{array}$ & E1015 N1000 & & E1015 & N1001 & & E1016 & N1001 & & \multicolumn{9}{|c|}{ E1022 N1065 } \\
\hline & Elevations & 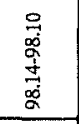 & 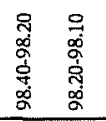 & 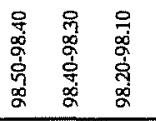 & $\begin{array}{ll}8 & 0 \\
00 & 0 \\
0 & 0 \\
0 & 0 \\
0 & 0 \\
\infty & 0 \\
0 & 0 \\
0\end{array}$ & 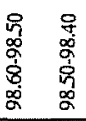 & 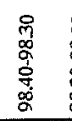 & 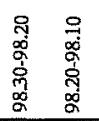 & 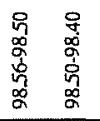 & 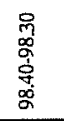 & 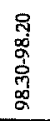 & $\begin{array}{l}0 \\
\text { s. } \\
\text { th } \\
\text { \& }\end{array}$ & $\begin{array}{l}9 \\
\frac{9}{8} \\
\text { 离 } \\
8\end{array}$ & 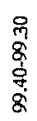 & $\begin{array}{l}\text { व్ } \\
\text { \&. } \\
\text { क्रें } \\
\text { \& }\end{array}$ & $\begin{array}{l}\text { 을 } \\
\text { क्षे } \\
\text { के }\end{array}$ & $\begin{array}{l}8 \\
\text { के } \\
0 \\
0 \\
\end{array}$ & $\begin{array}{l}8 \\
8 \\
0 \\
0 \\
0 \\
8\end{array}$ & 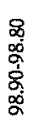 & 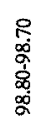 \\
\hline Artifacts & Levels & 1 & 12 & $\begin{array}{lll}1 & 2 & 3 \\
\end{array}$ & 12 & $2 \quad 3$ & 4 & $5 \quad 6$ & 12 & 3 & 4 & 1 & 2 & 3 & 4 & 5 & 6 & 7 & 8 & 9 \\
\hline 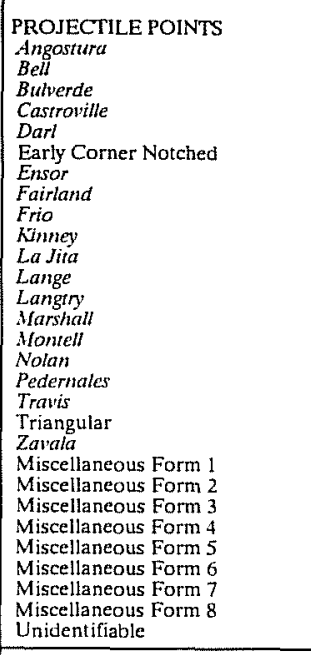 & & & & & & & & & & & 1 & & & 1 & 1 & 1 & 1 & & 1 & \\
\hline 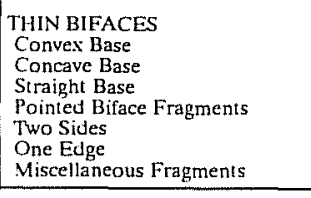 & & & & & & & & & & & & & 1 & & 1 & & 1 & & 2 & \\
\hline DISTALLY BEVELED BIFACE & & & & & & & & & & & & & & & & 1 & & & & \\
\hline $\begin{array}{l}\text { THICK BIFACES } \\
\text { CConvex Base with Convex Sides } \\
\text { Straight Base } \\
\text { Concex Edges } \\
\text { Fragments } \\
\end{array}$ & & & & & & & & & & & & & & 1 & 1 & & & & & \\
\hline $\begin{array}{l}\text { RETOUCHED FLAKES } \\
\text { One Side } \\
\text { Tho Sides } \\
\text { One End } \\
\text { One End and One Side } \\
\text { One End and Tho Sides } \\
\text { Bifacial Edges } \\
\end{array}$ & & & & & & & & & & & & & $\begin{array}{l}1 \\
3\end{array}$ & 1 & $\begin{array}{l}1 \\
1\end{array}$ & 1 & 1 & & 1 & \\
\hline $\begin{array}{l}\text { RETOUCHED CHIPS } \\
\text { One Side } \\
\text { Two Sides } \\
\text { Three Sides }\end{array}$ & & & 1 & & & & & & & & & & 3 & 1 & ${ }^{2}$ & 1 & & & 2 & \\
\hline
\end{tabular}




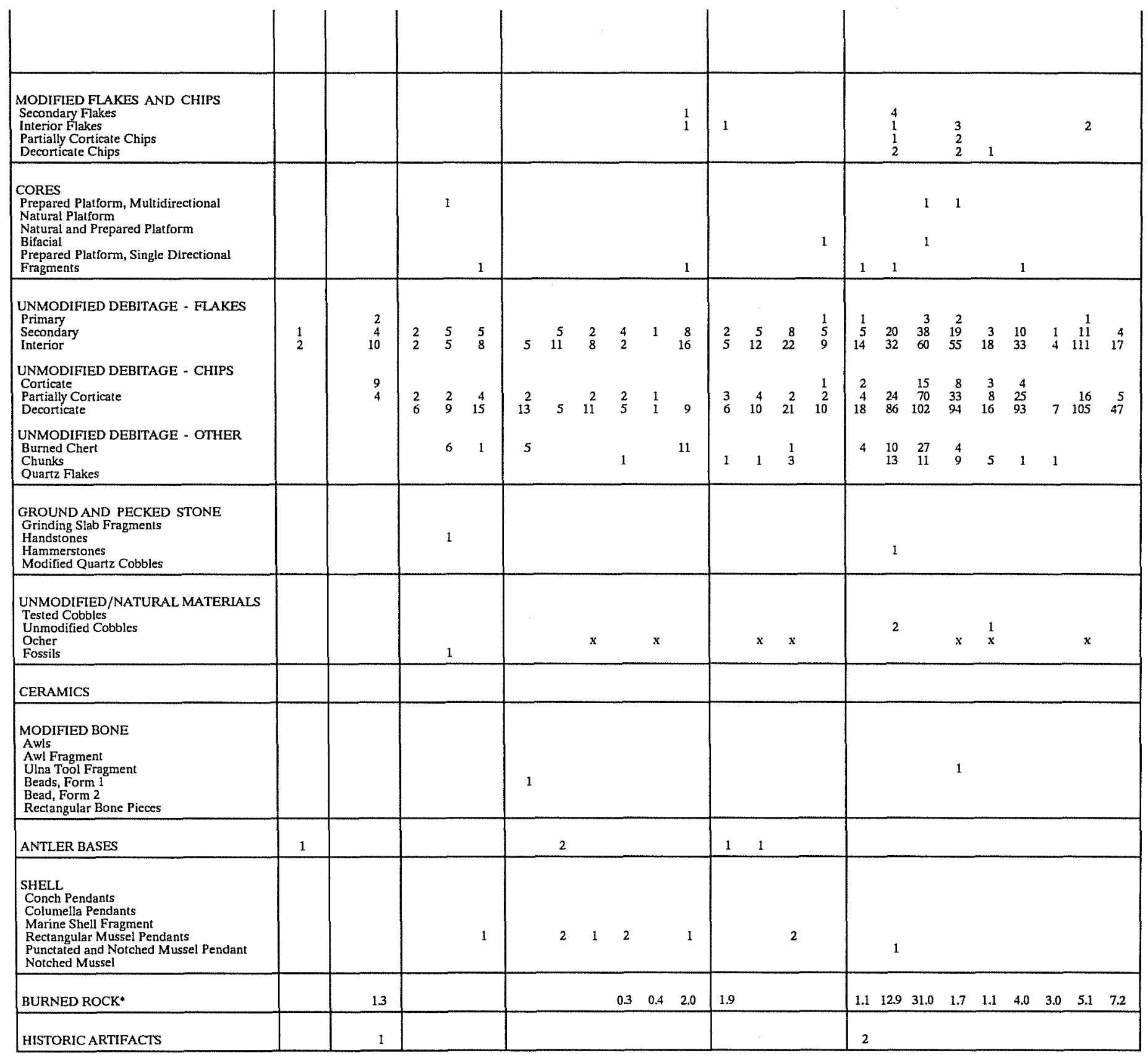

Burned rock weights to nearest tenth of a kilogram
$x=$ presence 


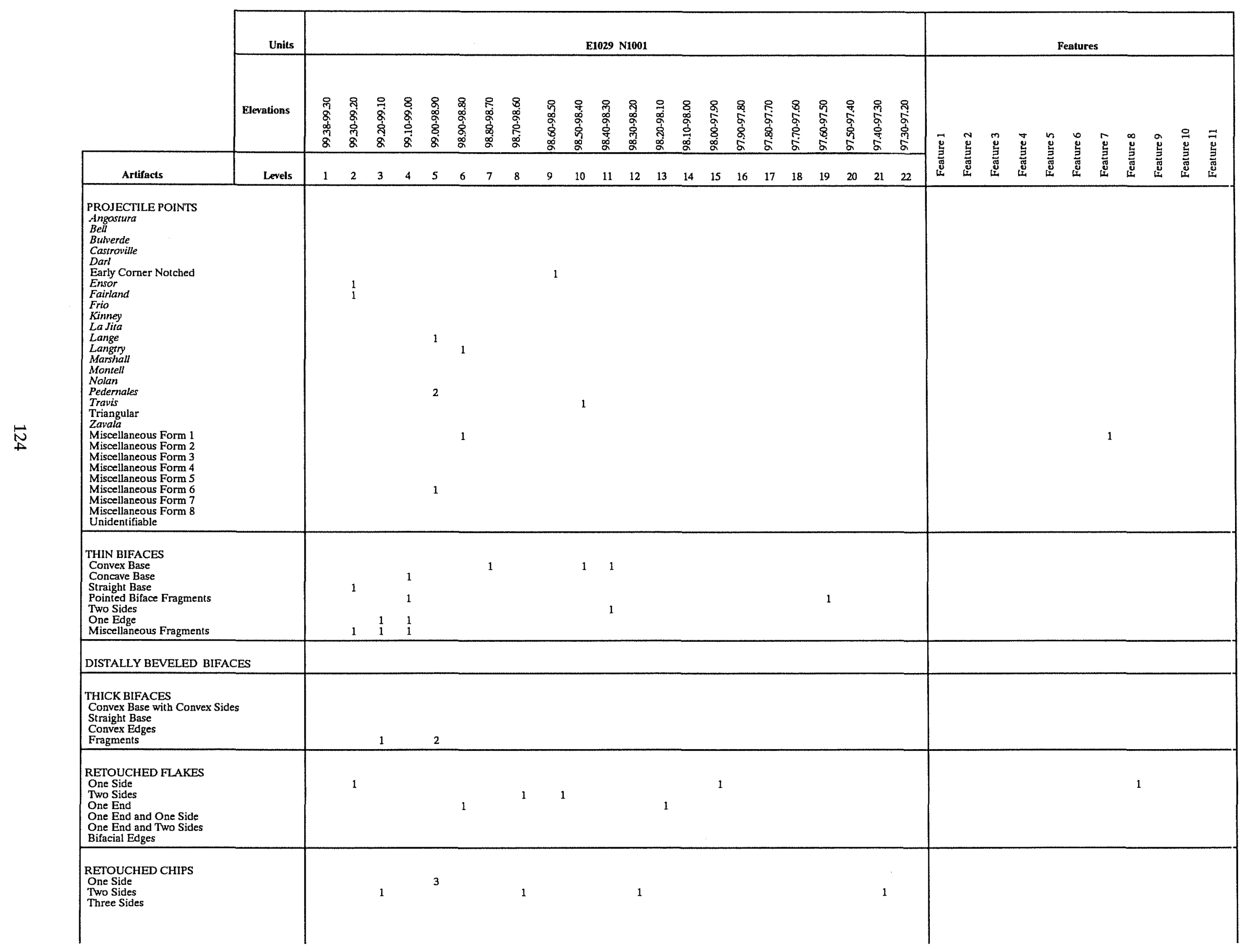




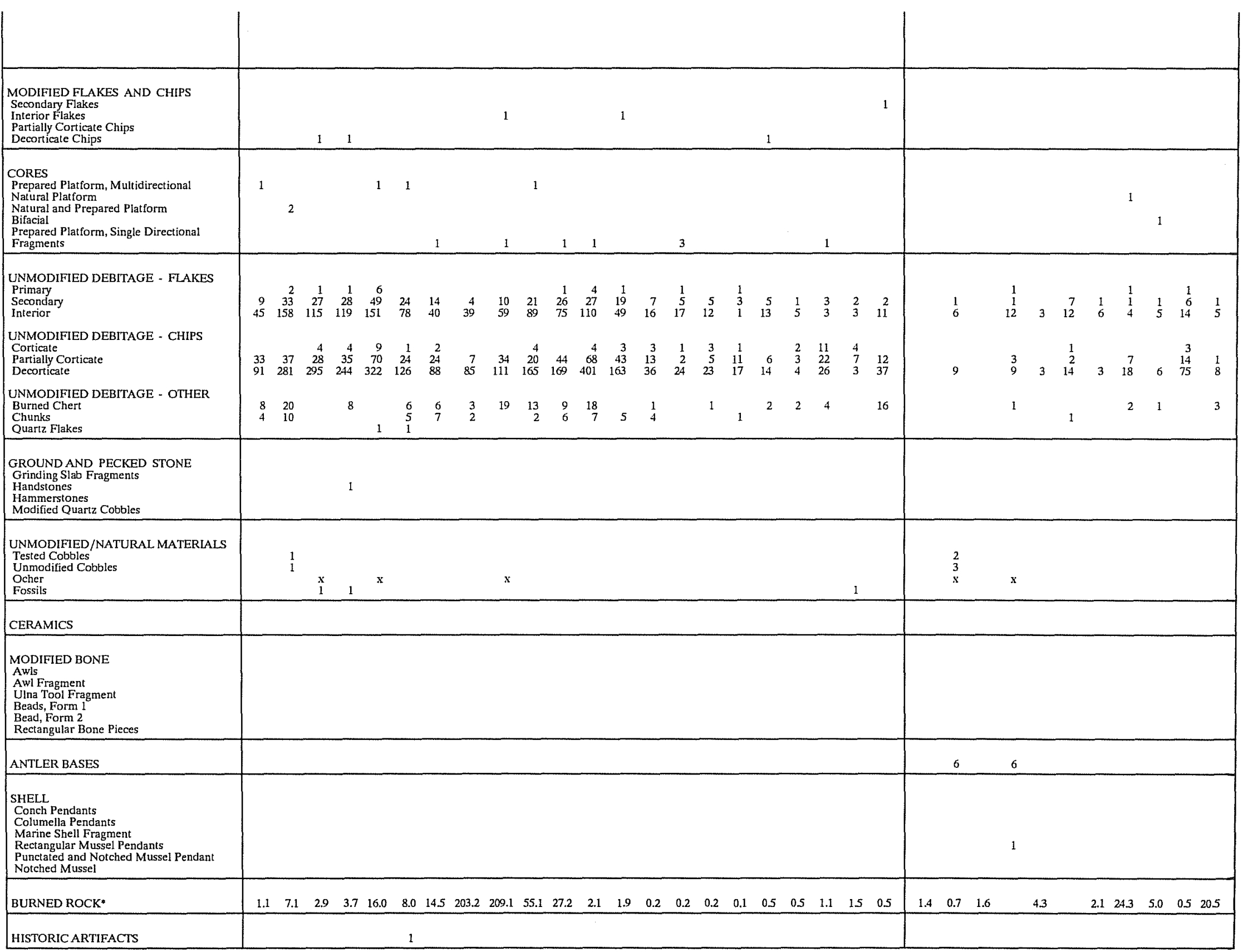




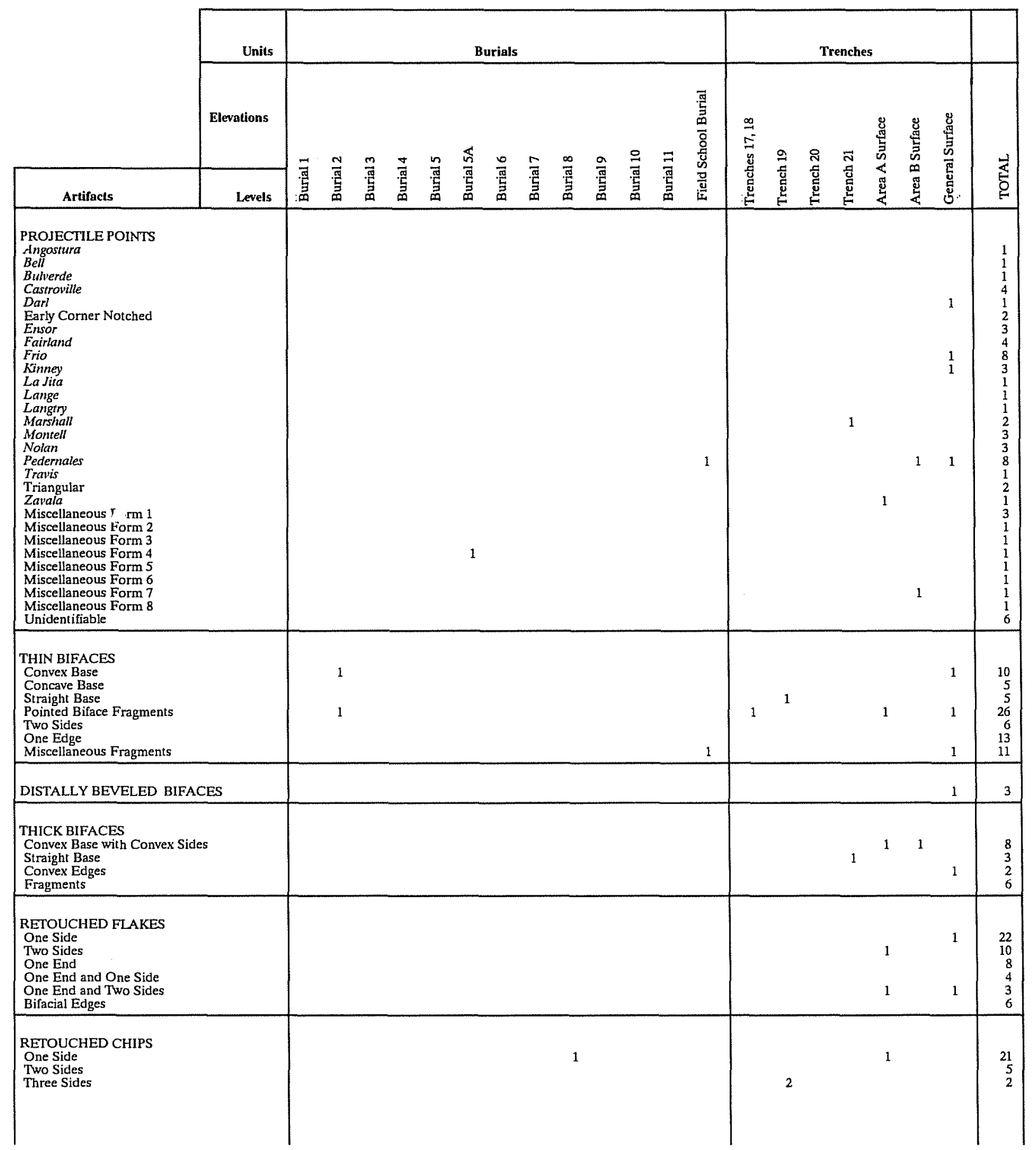




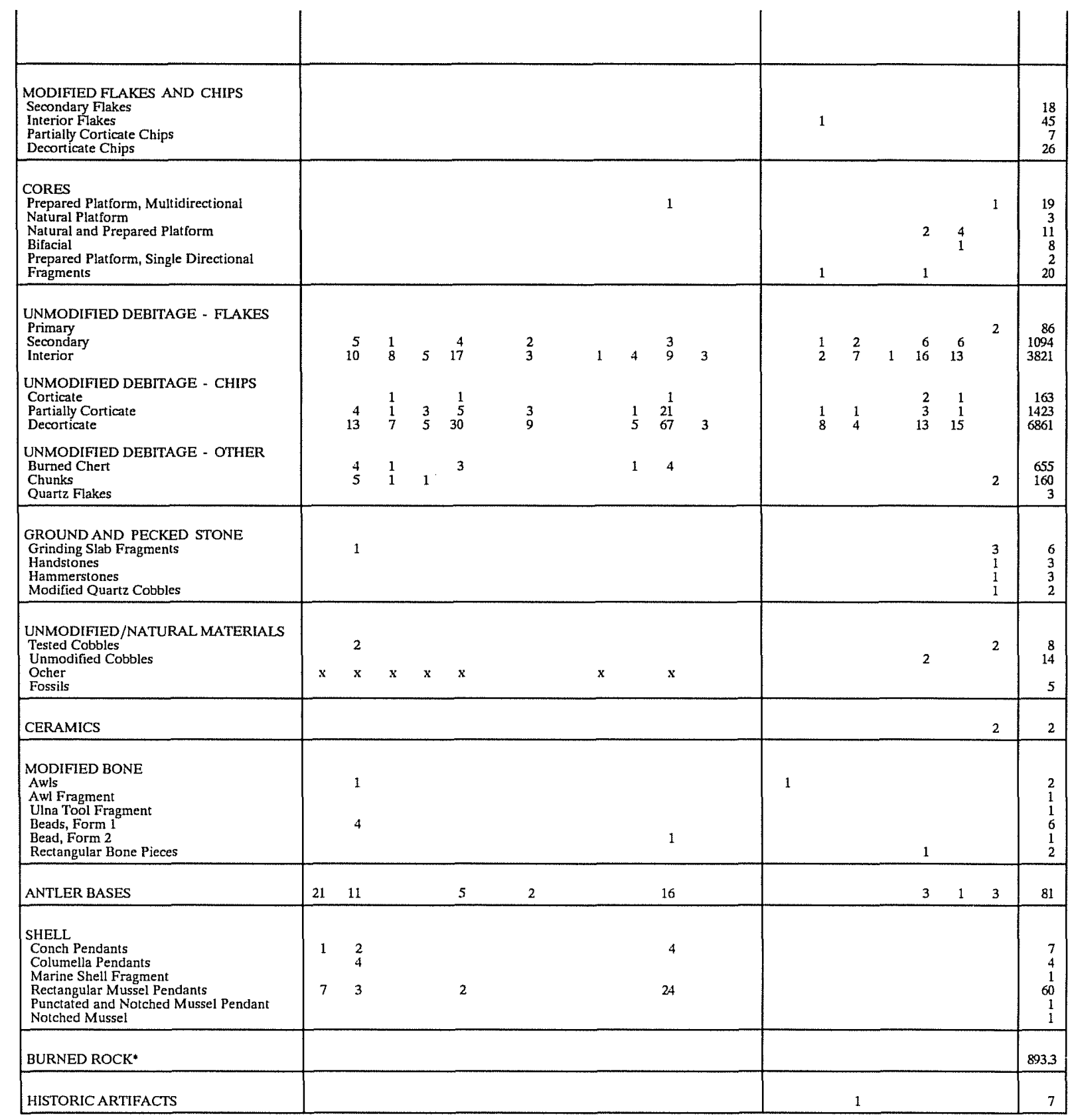


APPENDIX IV

FAUNAL REMAINS

Robert F. Scott IV

TABLE 6. SPECIES IDENTIFIED FROM 41 BX 1

\begin{tabular}{|c|c|c|c|c|}
\hline $\begin{array}{l}\text { Common } \\
\text { Name }\end{array}$ & $\begin{array}{l}\text { Scientific } \\
\text { Name }\end{array}$ & $\begin{array}{l}\text { Zone } 2 \\
\text { Area A }\end{array}$ & $\begin{array}{l}\text { Zone } 2 \\
\text { Area B }\end{array}$ & Zone 3 \\
\hline Turtle & Emydidae & 11 & & 4 \\
\hline Softshell turtle & Trionyx sp. & 1 & & \\
\hline Box turtle & Tenepene sp. & 3 & & \\
\hline Slider turtle & Pseudemys sp. & 1 & & \\
\hline Water snake & Natrix sp. & 4 & & \\
\hline Fish & Percordei & 3 & & \\
\hline Birds & Passerines & 6 & & \\
\hline Rodent & & 18 & 2 & \\
\hline Wood rat & Neotoma sp. & 2 & & \\
\hline Cottontail rabbit & Sylvilagus floridanus & 13 & 1 & 2 \\
\hline Black-tailed jackrabbit & Lepus californicus & 3 & & \\
\hline \multirow[t]{2}{*}{ Canid } & Canidae & 3 & & \\
\hline & Canis sp. & 7 & 1 & \\
\hline Raccoon & Procyon lotor & 10 & 1 & \\
\hline Badger & Tanidea taxus & 1 & & \\
\hline White-tailed deer & Odocoileus virginianus & 53 & 6 & 4 \\
\hline Antelope & Antilocapra americana & 9 & & 3 \\
\hline Bison & Bison bison & 4 & & 8 \\
\hline TOTAL & & 152 & 11 & 21 \\
\hline
\end{tabular}


TABLE 7. DISTRIBUTION OF BONE FROM 41 BX 1

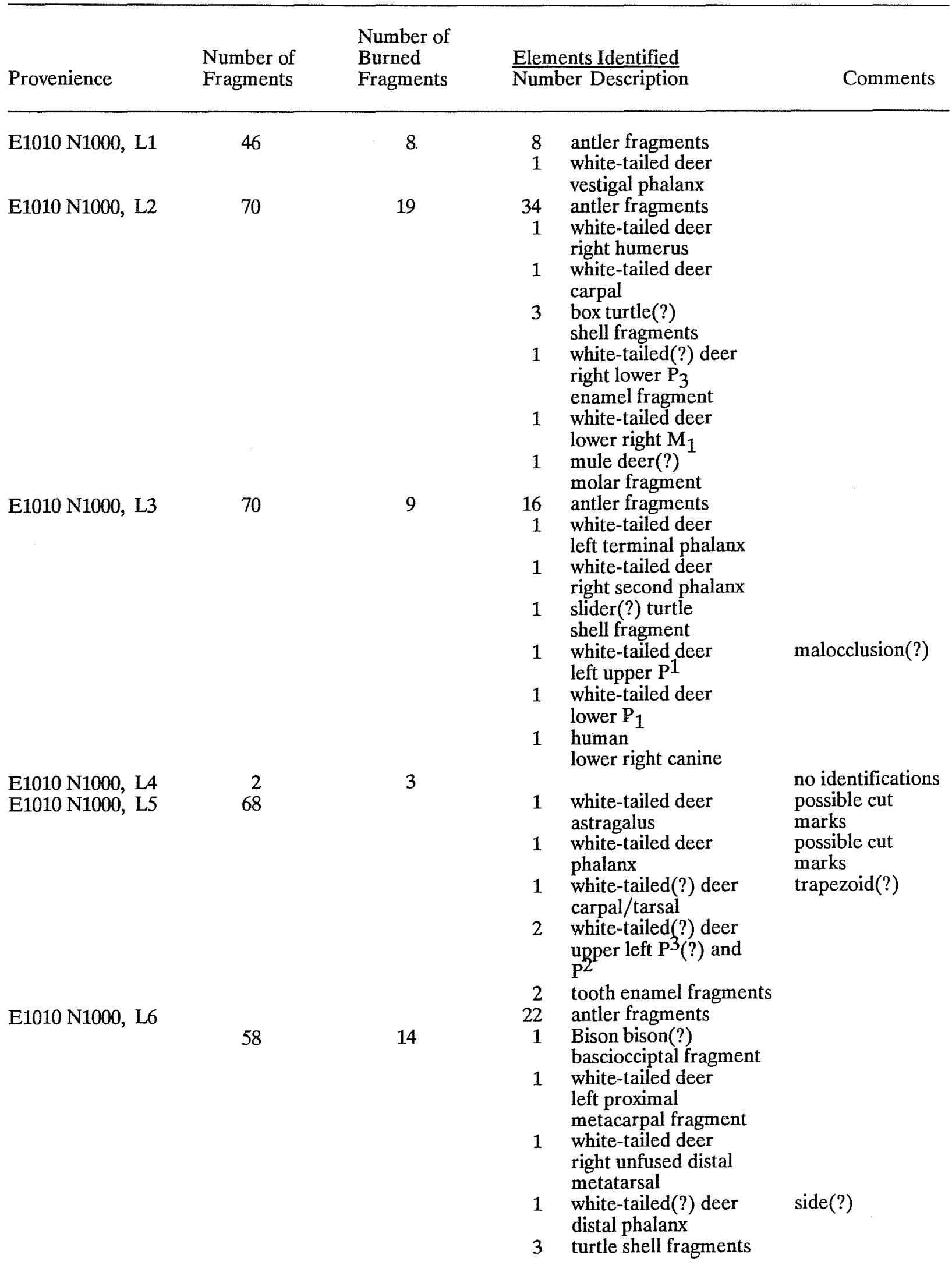


TABLE 7. (continued)

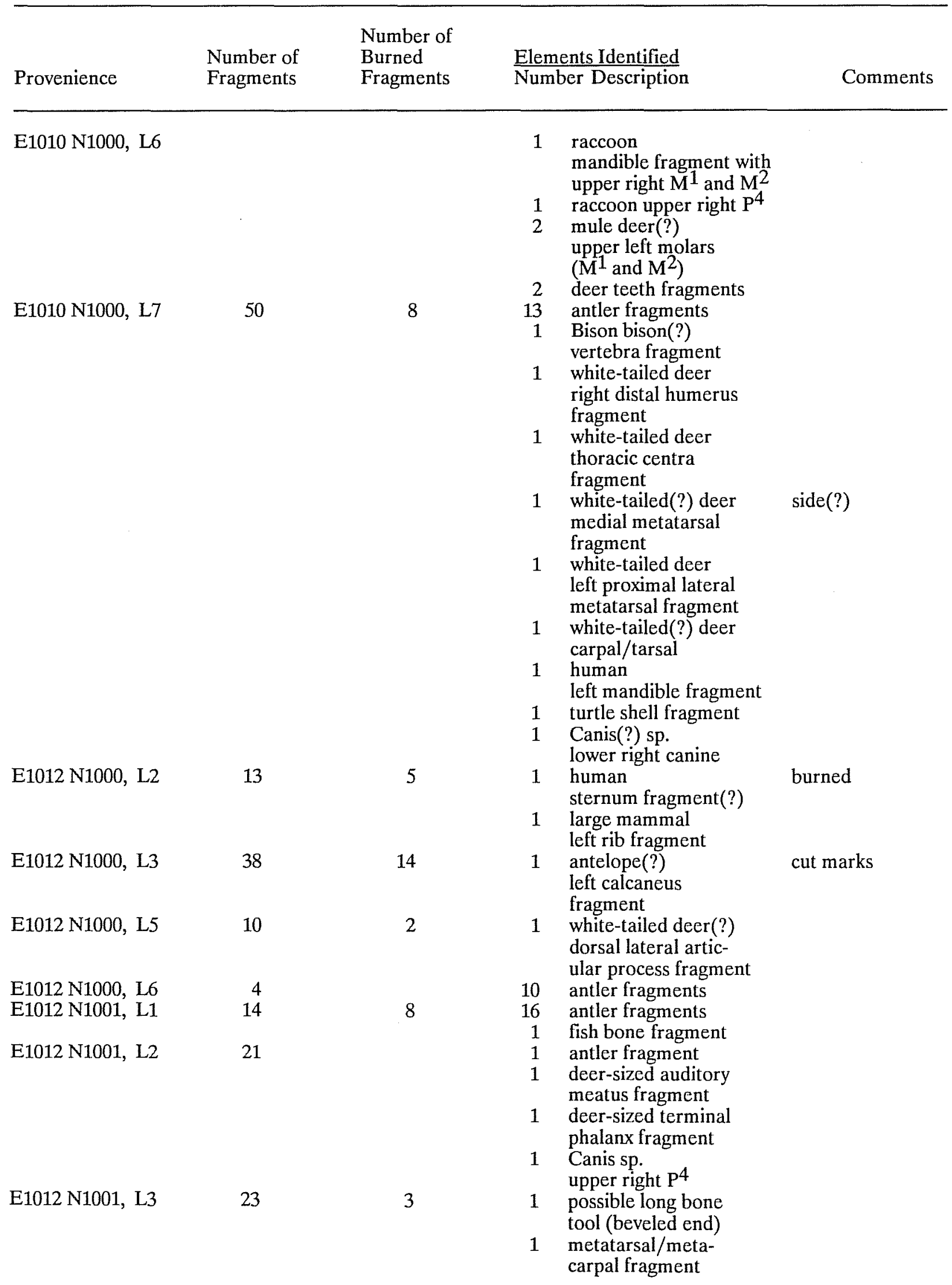


TABLE 7. (continued)

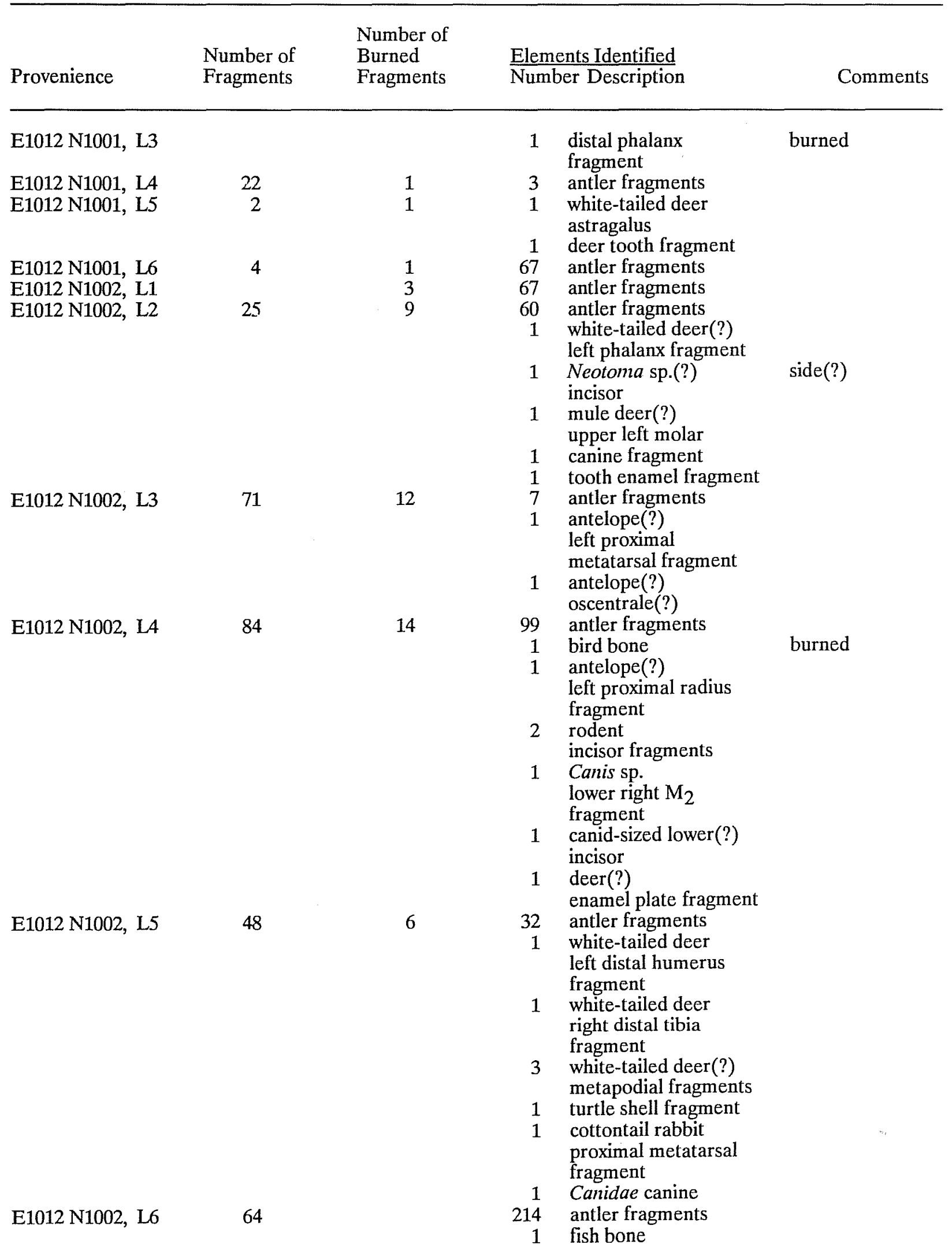


TABLE 7. (continued)

\begin{tabular}{|c|c|c|c|c|c|}
\hline $\begin{array}{l}\text { Provenience } \\
\text { E1012 N1002, L6 }\end{array}$ & $\begin{array}{l}\text { Number of } \\
\text { Fragments }\end{array}$ & $\begin{array}{l}\text { Number of } \\
\text { Burned } \\
\text { Fragments }\end{array}$ & \multicolumn{2}{|c|}{$\frac{\text { Elements Identified }}{\text { Number Description }}$} & Comments \\
\hline & & & $\begin{array}{l}1 \\
1 \\
1\end{array}$ & $\begin{array}{l}\text { badger phalanx(?) } \\
\text { Trionyxsp. turtle } \\
\text { shell fragment } \\
\text { cottontail rabbit } \\
\text { right proximal } \\
\text { metatarsal } \\
\text { rodent } \\
\text { long bone fragment } \\
\text { white-tailed deer } \\
\text { distal humerus } \\
\text { fragment } \\
\text { artiodactyl distal } \\
\text { phalanx fragment } \\
\text { deer-sized meta- } \\
\text { tarsal fragment } \\
\text { Canis(?) sp. } \\
\text { lower left canine(?) } \\
\text { cottontail(?) rabbit } \\
\text { lower right incisor }\end{array}$ & polished \\
\hline E1012 N1002, L7 & 32 & 6 & $\begin{array}{r}13 \\
1\end{array}$ & $\begin{array}{l}\text { antler fragments } \\
\text { human left lunate }\end{array}$ & \\
\hline E1012 N1002, L8 & 61 & 3 & $\begin{array}{l}6 \\
1 \\
1\end{array}$ & $\begin{array}{l}\text { antler fragments } \\
\text { human lunate } \\
\text { white-tailed deer } \\
\text { right medial distal } \\
\text { metatarsal fragments }\end{array}$ & $\begin{array}{l}\text { partially unfused } \\
\text { cut marks }\end{array}$ \\
\hline E1012 N1002, L9 & 24 & & $\begin{array}{l}1 \\
1 \\
1\end{array}$ & $\begin{array}{l}\text { antler fragments } \\
\text { white-tailed deer } \\
\text { left dorsal distal } \\
\text { tibia fragment } \\
\text { human } \\
\text { mandible fragment } \\
\text { skull fragment } \\
\text { bird bone fragment }\end{array}$ & $\begin{array}{l}\text { cut marks } \\
\text { polished }\end{array}$ \\
\hline E1012 N1002, L10 & 12 & 4 & $\begin{array}{r}14 \\
1 \\
1 \\
1 \\
1\end{array}$ & $\begin{array}{l}\text { antler fragments } \\
\text { white-tailed deer } \\
\text { second phalanx } \\
\text { white-tailed deer(?) } \\
\text { phalanx fragment } \\
\text { bird bone fragment }\end{array}$ & front right(?) \\
\hline $\begin{array}{l}\text { E1012 N1002, L11 } \\
\text { E1012 N1002, L12 }\end{array}$ & $\begin{array}{r}14 \\
6\end{array}$ & $\begin{array}{l}6 \\
3\end{array}$ & $\begin{array}{l}2 \\
1 \\
1\end{array}$ & $\begin{array}{l}\text { antler fragments } \\
\text { antler fragment } \\
\text { jackrabbit } \\
\text { mandible fragment }\end{array}$ & \\
\hline $\begin{array}{ll}\text { E1013 N996, } & \text { L1 } \\
\text { E1013 N997, } & \text { L1 } \\
\text { E1013 N998, } & \text { L1 }\end{array}$ & $\begin{array}{l}2 \\
4 \\
1\end{array}$ & 6 & $\begin{array}{l}2 \\
3 \\
3\end{array}$ & $\begin{array}{l}\text { antler fragments } \\
\text { antler fragments } \\
\text { antler fragments }\end{array}$ & \\
\hline $\begin{array}{ll}\text { E1013 N998, } & \text { L2 } \\
\text { E1013 N998, } & \text { L3 } \\
\text { E1013 N999, } & \text { L1 }\end{array}$ & $\begin{array}{r}7 \\
1 \\
10\end{array}$ & . & $\begin{array}{l}1 \\
6\end{array}$ & antler fragment & no identifications \\
\hline
\end{tabular}


TABLE 7. (continued)

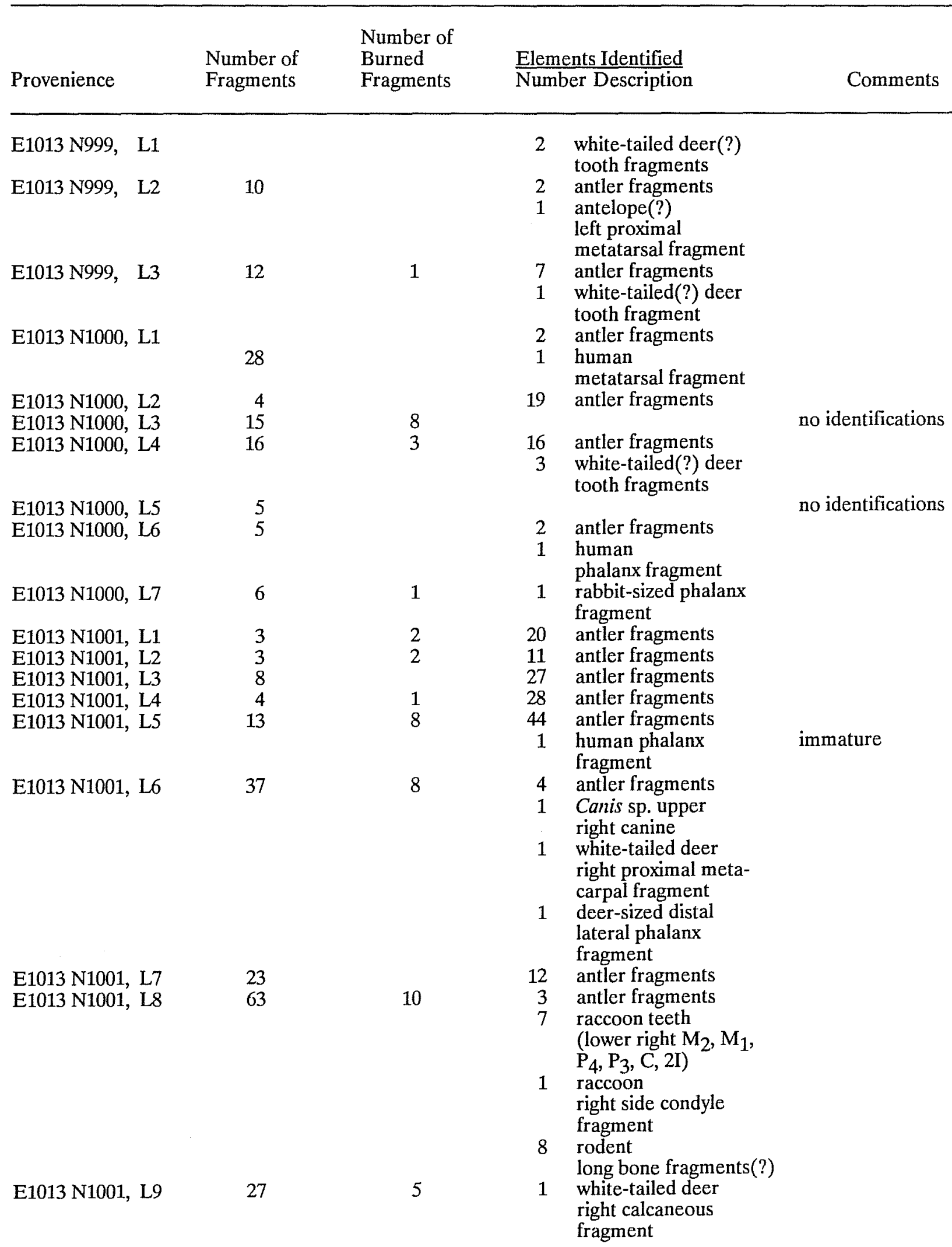


TABLE 7. (continued)

\begin{tabular}{|c|c|c|c|c|c|}
\hline \multirow{2}{*}{$\begin{array}{l}\text { Provenience } \\
\text { E1013 N1001, L9 }\end{array}$} & \multirow{2}{*}{$\begin{array}{l}\text { Number of } \\
\text { Fragments }\end{array}$} & \multirow{2}{*}{$\begin{array}{l}\text { Number of } \\
\text { Burned } \\
\text { Fragments }\end{array}$} & \multicolumn{2}{|c|}{$\frac{\text { Elements Identified }}{\text { Number Description }}$} & \multirow[t]{2}{*}{ Comments } \\
\hline & & & $\begin{array}{l}1 \\
1\end{array}$ & $\begin{array}{l}\text { antelope(?) } \\
\text { right distal scapula } \\
\text { fragment } \\
\text { deer-sized phalanx } \\
\text { distal phalanx right } \\
\text { side fragment }\end{array}$ & \\
\hline E1013 N1001, L10 & 22 & 1 & 2 & $\begin{array}{l}\text { cottontail(?) rabbit } \\
\text { incisors }\end{array}$ & \\
\hline E1014 N996, L1 & 50 & 2 & 11 & antler fragments & \\
\hline E1014 N997, L1 & 17 & 7 & $\begin{array}{r}11 \\
1\end{array}$ & $\begin{array}{l}\text { antler fragments } \\
\text { cottontail rabbit molar }\end{array}$ & \\
\hline E1014 N998, L1 & 62 & 5 & $\begin{array}{l}1 \\
2 \\
1 \\
1 \\
1 \\
1\end{array}$ & $\begin{array}{l}\text { antler base } \\
\text { human bone fragments } \\
\text { deer-sized phalanx } \\
\text { fragment } \\
\text { jackrabbit } \\
\text { right calcaneous } \\
\text { fragment } \\
\text { rodent incisor fragment }\end{array}$ & $\begin{array}{l}\text { immature } \\
\text { burned }\end{array}$ \\
\hline E1014 N1000, L1 & 62 & 4 & $\begin{array}{r}7 \overrightarrow{8} \\
1 \\
1\end{array}$ & $\begin{array}{l}\text { antler fragments } \\
\text { white-tailed deer } \\
\text { right orbit fragment } \\
\text { white-tailed deer } \\
\text { frontal fragment }\end{array}$ & \\
\hline E1014 N1000, L2 & 94 & & $\begin{array}{r}170 \\
1\end{array}$ & $\begin{array}{l}\text { antler fragments } \\
\text { white-tailed deer } \\
\text { mandible symphysis } \\
\text { fragment }\end{array}$ & \\
\hline E1014 N1000, L3 & 32 & & $\begin{array}{r}1 \\
28\end{array}$ & $\begin{array}{l}\text { Canis sp. } \\
\text { lower right } \mathrm{P}_{4} \\
\text { antler fragments }\end{array}$ & \\
\hline E1014 N1000, L4 & 33 & 2 & $\begin{array}{r}54 \\
1\end{array}$ & $\begin{array}{l}\text { antler fragments } \\
\text { artiodactyl } \\
\text { metacarpal/ } \\
\text { metatarsal }\end{array}$ & burned \\
\hline E1014 N1001, L1 & 4 & & 9 & antler fragments & \\
\hline E1014 N1001, L2 & 6 & 3 & $\begin{array}{r}19 \\
1\end{array}$ & $\begin{array}{l}\text { antler fragments } \\
\text { cottontail rabbit } \\
\text { tooth fragment }\end{array}$ & \\
\hline E1014 N1001, L3 & 35 & 1 & $\begin{array}{l}4 \\
1\end{array}$ & $\begin{array}{l}\text { antler fragments } \\
\text { antelope(?) } \\
\text { left naviculo-cuboid }\end{array}$ & \\
\hline E1014 N1001, L4 & 67 & 3 & $\begin{array}{r}30 \\
1 \\
1\end{array}$ & $\begin{array}{l}\text { antler fragments } \\
\text { rodent tibiofibula } \\
\text { white-tailed deer } \\
\text { proximal lateral } \\
\text { phalanx fragment } \\
\text { claw }\end{array}$ & \\
\hline E1014 N1001, L5 & 44 & 2 & 45 & $\begin{array}{l}\text { antler fragments } \\
\text { (includes one antler } \\
\text { base) }\end{array}$ & \\
\hline $\begin{array}{l}\text { E1014 N1001, L6 } \\
\text { E1014 N1001, L7 }\end{array}$ & $\begin{array}{l}32 \\
30\end{array}$ & 5 & $\begin{array}{l}1 \\
2\end{array}$ & $\begin{array}{l}\text { rodent molar fragment } \\
\text { antler fragments }\end{array}$ & \\
\hline
\end{tabular}


TABLE 7. (continued)

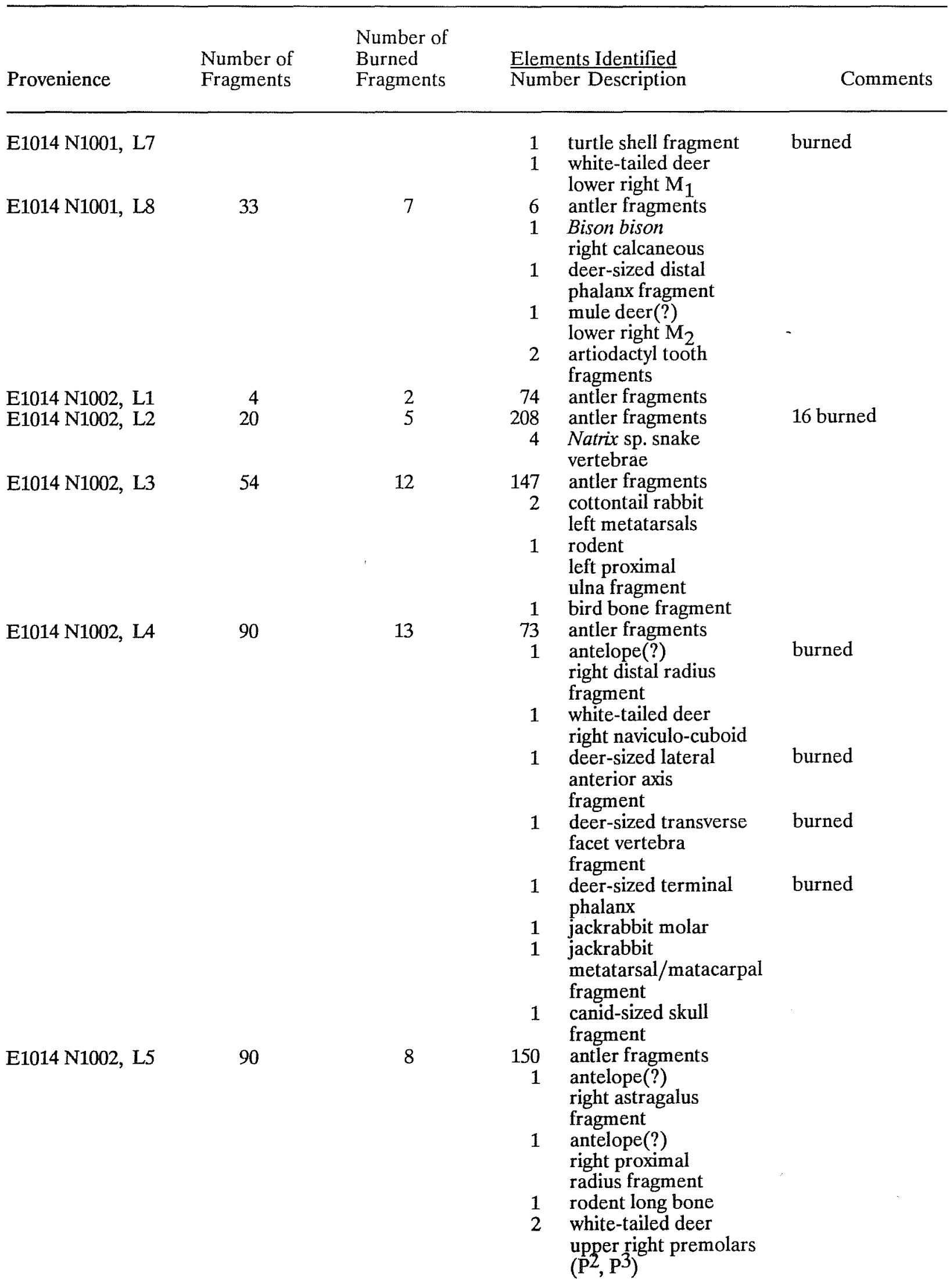


TABLE 7. (continued)

\begin{tabular}{|c|c|c|c|c|c|}
\hline \multirow{2}{*}{$\begin{array}{l}\text { Provenience } \\
\text { E1014 N1002, L6 }\end{array}$} & \multirow{2}{*}{$\begin{array}{l}\text { Number of } \\
\text { Fragments } \\
73\end{array}$} & \multirow{2}{*}{$\begin{array}{l}\text { Number of } \\
\text { Burned } \\
\text { Fragments } \\
12\end{array}$} & \multicolumn{2}{|c|}{$\frac{\text { Elements Identified }}{\text { Number Description }}$} & \multirow{2}{*}{$\begin{array}{r}\text { Comments } \\
\text { cut marks }\end{array}$} \\
\hline & & & $\begin{array}{r}119 \\
1 \\
1 \\
1\end{array}$ & $\begin{array}{l}\text { antler fragments } \\
\text { large mammal long } \\
\text { bone fragment } \\
\text { fish bone } \\
\text { cottontail rabbit } \\
\text { proximal metatarsal/ } \\
\text { metacarpal fragment }\end{array}$ & \\
\hline $\begin{array}{l}\text { E1014 N1002, L7 } \\
\text { E1015 N997, L1 }\end{array}$ & $\begin{array}{l}56 \\
30\end{array}$ & 3 & $\begin{array}{l}20 \\
17\end{array}$ & $\begin{array}{l}\text { antler fragments } \\
\text { antler fragments } \\
\text { (includes antler base) }\end{array}$ & \\
\hline E1015 N999, L1 & 20 & 1 & $\begin{array}{r}10 \\
1\end{array}$ & $\begin{array}{l}\text { antler fragments } \\
\text { bird bone fragment }\end{array}$ & \\
\hline $\begin{array}{l}\text { E1015 N1000, L1 } \\
\text { E1015 N1000, L2 }\end{array}$ & $\begin{array}{r}62 \\
103\end{array}$ & 1 & $\begin{array}{r}12 \\
151\end{array}$ & $\begin{array}{l}\text { antler fragments } \\
\text { antler fragments }\end{array}$ & \\
\hline E1015 N1000, L3 & 33 & 1 & 36 & antler fragments & \\
\hline E1015 N1001, L1 & 49 & 3 & 141 & antler fragments & \\
\hline E1015 N1001, L2 & 69 & 1 & $\begin{array}{r}189 \\
1\end{array}$ & $\begin{array}{l}\text { antler fragments } \\
\text { (includes two bases) } \\
\text { mule deer(?) } \\
\text { upper left } \mathrm{M}^{1}\end{array}$ & \\
\hline E1015 N1001, L3 & 81 & & $\begin{array}{r}159 \\
1 \\
1 \\
3\end{array}$ & $\begin{array}{l}\text { antler fragments } \\
\text { Neotoma sp. } \\
\text { left distal humerus } \\
\text { fragment } \\
\text { turtle } \\
\text { mandible fragment(?) } \\
\text { turtle shell fragments }\end{array}$ & \\
\hline E1015 N1001, L4 & 31 & & 112 & antler fragments & \\
\hline E1015 N1001, L5 & 10 & & $\begin{array}{r}15 \\
1 \\
1\end{array}$ & $\begin{array}{l}\text { antler fragments } \\
\text { bison-sized long bone } \\
\text { fragment } \\
\text { white-tailed deer } \\
\text { right auditory meatus } \\
\text { fragment }\end{array}$ & \\
\hline E1015 N1001, L6 & 35 & & 1 & $\begin{array}{l}\text { artiodactyl enamel } \\
\text { fragment }\end{array}$ & \\
\hline E1016 N1001, L1 & 3 & & $\begin{array}{r}53 \\
1\end{array}$ & $\begin{array}{l}\text { antler fragments } \\
\text { (includes antler base) } \\
\text { artiodactyl enamel } \\
\text { fragment }\end{array}$ & \\
\hline E1016 N1001, L2 & 23 & & 131 & antler fragments & \\
\hline $\begin{array}{l}\text { E1016 N1001, L3 } \\
\text { E1016 N1001, L4 }\end{array}$ & $\begin{array}{l}32 \\
42\end{array}$ & $\begin{array}{l}1 \\
5\end{array}$ & $\begin{array}{r}77 \\
14 \\
1\end{array}$ & $\begin{array}{l}\text { antler fragments } \\
\text { antler fragments }\end{array}$ & \\
\hline & & & 1 & $\begin{array}{l}\text { white-tailed(?) deer } \\
\text { tooth fragment }\end{array}$ & \\
\hline $\begin{array}{l}\text { E1029 N1001, L1 } \\
\text { E1029 N1001, L2 }\end{array}$ & $\begin{array}{r}14 \\
110\end{array}$ & $\begin{array}{r}8 \\
51\end{array}$ & $\begin{array}{l}10 \\
23\end{array}$ & $\begin{array}{l}\text { antler fragments } \\
\text { antler fragments }\end{array}$ & \\
\hline E1029 N1001, L3 & 71 & 45 & $\begin{array}{r}3 \\
10 \\
1\end{array}$ & $\begin{array}{l}\text { small mammal bone } \\
\text { fragments } \\
\text { antler fragments } \\
\text { deer-sized right } \\
\text { posterior metatarsal } \\
\text { fragment }\end{array}$ & \\
\hline
\end{tabular}


TABLE 7. (continued)

\begin{tabular}{|c|c|c|c|c|c|}
\hline \multirow{2}{*}{$\begin{array}{l}\text { Provenience } \\
\text { E1029 N1001, L3 }\end{array}$} & \multirow[t]{2}{*}{$\begin{array}{l}\text { Number of } \\
\text { Fragments }\end{array}$} & \multirow[t]{2}{*}{$\begin{array}{l}\text { Number of } \\
\text { Burned } \\
\text { Fragments }\end{array}$} & \multicolumn{2}{|c|}{$\frac{\text { Elements Identified }}{\text { Number Description }}$} & \multirow[t]{2}{*}{ Comments } \\
\hline & & & 1 & $\begin{array}{l}\text { cottontail(?) rabbit } \\
\text { molar fragment }\end{array}$ & \\
\hline E1029 N1001, L4 & 57 & 7 & 15 & antler fragments & \\
\hline E1029 N1001, L5 & 141 & 18 & $\begin{array}{r}11 \\
1 \\
1 \\
1 \\
1 \\
1 \\
1 \\
2 \\
2 \\
1\end{array}$ & $\begin{array}{l}\text { antler fragments } \\
\text { squirrel-sized } \\
\text { auditory bulla } \\
\text { deer-sized left } \\
\text { phalanx fragment } \\
\text { deer-sized } \\
\text { calcaneous fragment } \\
\text { deer-sized metatarsal/ } \\
\text { metacarpal fragment } \\
\text { rodent bone fragment } \\
\text { mule deer(?) } \\
\text { upper left } \mathrm{P}^{4} \\
\text { large enamel plate } \\
\text { fragments } \\
\text { Canis sp. } \\
\text { upper right } \mathrm{I}^{3}\end{array}$ & \\
\hline E1029 N1001, L6 & 87 & & $\begin{array}{r}23 \\
1 \\
1\end{array}$ & $\begin{array}{l}\text { antler fragments } \\
\text { raccoon } \\
\text { lower right } \mathrm{M}_{2} \\
\text { enamel plate fragment }\end{array}$ & immature \\
\hline E1029 N1001, L7 & 6 & 1 & $\begin{array}{l}3 \\
1\end{array}$ & $\begin{array}{l}\text { antler fragments } \\
\text { white-tailed deer } \\
\text { upper right } \mathrm{M}^{2}\end{array}$ & \\
\hline E1029 N1001, L8 & 6 & & & & no identifications \\
\hline E1029 N1001, L9 & 26 & 5 & $\begin{array}{l}2 \\
1\end{array}$ & $\begin{array}{l}\text { white-tailed deer } \\
\text { tooth fragments } \\
\text { white-tailed(?) deer } \\
\text { tooth fragment }\end{array}$ & burned \\
\hline E1029 N1001, L10 & 45 & 7 & $\begin{array}{l}1 \\
1 \\
1 \\
1\end{array}$ & $\begin{array}{l}\text { white-tailed deer } \\
\text { left distal lateral } \\
\text { humerus fragment } \\
\text { deer-sized carpal/ } \\
\text { tarsal } \\
\text { incised metatarsal } \\
\text { fragment } \\
\text { mule deer(?) } \\
\text { upper right }{ }^{3} \\
\text { tooth fragment }\end{array}$ & tool(?) burned \\
\hline E1029 N1001, L11 & 22 & 3 & & & no identifications \\
\hline E1029 N1001, L12 & 13 & 5 & 1 & $\begin{array}{l}\text { human(?) } \\
\text { internal auditory } \\
\text { meatus }\end{array}$ & \\
\hline E1029 N1001, L13 & & 1 & & & no identifications \\
\hline E1029 N1001, L19 & 5 & & & & no identifications \\
\hline E1029 N1001, L20 & 1 & & & & no identifications \\
\hline E1029 N1001, L22 & 1 & & & & no identifications \\
\hline E1022 N1065, L1 & 13 & & $\begin{array}{l}7 \\
1\end{array}$ & $\begin{array}{l}\text { antler fragments } \\
\text { Bison bison(?) } \\
\text { enamel plate }\end{array}$ & \\
\hline E1022 N1065, L2 & 274 & 14 & 6 & $\begin{array}{l}\text { bison-sized bone } \\
\text { fragments }\end{array}$ & $\begin{array}{l}\text { includes rib } \\
\text { tool(?) }\end{array}$ \\
\hline
\end{tabular}


TABLE 7. (continued)

\begin{tabular}{|c|c|c|c|c|c|}
\hline \multirow{2}{*}{$\begin{array}{l}\text { Provenience } \\
\text { E1022 N1065, L2 }\end{array}$} & \multirow{2}{*}{$\begin{array}{l}\text { Number of } \\
\text { Fragments }\end{array}$} & \multirow{2}{*}{$\begin{array}{l}\text { Number of } \\
\text { Burned } \\
\text { Fragments }\end{array}$} & \multicolumn{2}{|c|}{$\frac{\text { Elements Identified }}{\text { Number Description }}$} & \multirow[t]{2}{*}{ Comments } \\
\hline & & & 1 & $\begin{array}{l}\text { white-tailed(?) deer } \\
\text { left distal scapula } \\
\text { fragment } \\
\text { white-tailed(?) deer } \\
\text { first left proximal } \\
\text { phalanx fragment }\end{array}$ & \\
\hline E1022 N1065, L3 & 117 & 8 & $\begin{array}{l}1 \\
1 \\
1 \\
1 \\
1 \\
1\end{array}$ & $\begin{array}{l}\text { cottontail rabbit } \\
\text { calcaneous } \\
\text { turtle shell fragments } \\
\text { antelope(?) } \\
\text { right lateral axis } \\
\text { fragment } \\
\text { antelope(?) } \\
\text { metacarpal fragment } \\
\text { metapodial condyle } \\
\text { fragment } \\
\text { white-tailed deer } \\
\text { internal auditory } \\
\text { meatus } \\
\text { bison-sized right } \\
\text { scapula fragment } \\
\text { metapodial } \\
\text { enamel plate } \\
\text { fragment }\end{array}$ & tool fragment \\
\hline E1022 N1065, L4 & 54 & 9 & & & no identifications \\
\hline E1022 N1065, L5 & 42 & 17 & $\begin{array}{l}4 \\
1 \\
1\end{array}$ & $\begin{array}{l}\text { antler fragments } \\
\text { cottontail rabbit } \\
\text { right distal humerus } \\
\text { fragment } \\
\text { white-tailed(?) deer } \\
\text { lower left molar } \\
\text { fragment }\end{array}$ & \\
\hline E1022 N1065, L6 & 60 & 8 & 1 & $\begin{array}{l}\text { antelope(?) } \\
\text { lateral phalanx } \\
\text { fragment(?) }\end{array}$ & \\
\hline $\begin{array}{l}\text { E1022 N1065, L7 } \\
\text { E1022 N1065, L8 } \\
\text { E1022 N1065, L9 }\end{array}$ & $\begin{array}{r}5 \\
18 \\
4\end{array}$ & $\begin{array}{r}10 \\
1\end{array}$ & 1 & antler fragment & $\begin{array}{l}\text { no identifications } \\
\text { burned }\end{array}$ \\
\hline
\end{tabular}



